\title{
Revisão taxonômica de Croton sect. Lamprocroton (Müll. Arg.) Pax (Euphorbiaceae s.s.)
}

\author{
Letícia Ribes de Lima ${ }^{1,3}$ \& José Rubens Pirani ${ }^{2}$
}

\author{
${ }^{1}$ Instituto de Botânica, Seção de Curadoria do Herbário, \\ Av. Miguel Stéfano, 3687, Água Funda, CEP 04301-902, São Paulo, SP, Brasil \\ ${ }^{2}$ Departamento de Botânica do Instituto de Biociências - IB, Universidade de São Paulo - USP, \\ Rua do Matão, Travessa 14, 321, Cidade Universitária, CP 11461, CEP 05422-970, São Paulo, SP, Brasil \\ ${ }^{3}$ Autor para correspondência: Letícia Ribes de Lima, e-mail: lerilima@hotmail.com, \\ http://www.ibot.sp.gov.br
}

LIMA, L.R. \& PIRANI, J.R. 2008. Taxonomic revision of Croton sect. Lamprocroton (Müll. Arg.) Pax (Euphorbiaceae s.s.). Biota Neotrop. 8(2): http://www.biotaneotropica.org.br/v8n2/en/abstract?taxonomicreview+bn01108022008.

\begin{abstract}
Croton is the second bigger and more diverse genus in the family Euphorbiaceae, with about 1,200 species distributed in 40 sections, occurring in all tropical areas, most of them in Americas. In South America, Brazil is the country in which a larger number of taxa are found, ca. 356. According to recent classification, the genus belongs to the tribe Crotoneae, and despite the wide and morphological diversity, it would be a monophyletic taxon. However, a phylogenetic analysis using markers of ITS region from nuclear ribosomal DNA, and of trnL-F from plastidial DNA, showed that Croton, like traditionally circumscribed, is not a monophyletic taxon. A taxonomic revision of Croton section Lamprocroton (Müll. Arg.) Pax is presented here. It is a Neotropical group with most of its species occurring from Southeast and South Brazil to southern South America (Uruguay and Argentina). Morphologically, the members of Lamprocroton are characterized as monoecious or dioecious shrubs or subshrubs, with a lepidote indumentum at least in part of foliage, entire leaves with no glands. The staminate flowers have 9 to 16 stamens and the pistillate flowers may have equal or unequal sepals, reduced to absent petals, and styles once or twice bifid. Overall, are recognized 26 species in the group, three of them new to the science. Identification key, morphological descriptions, illustrations, phenological period, as well as data on geographic distribution and general comments of each species are presented. Four taxa were excluded from $C$. sect. Lamprocroton because they do not show the morphological features that are diagnostics of the section. Four species that are poorly known were not included in the taxonomic treatment.
\end{abstract}

Keywords: Croton, Euphorbiaceae, floristic, taxonomic revision.

LIMA, L.R. \& PIRANI, J.R. 2008. Revisão taxonômica de Croton sect. Lamprocroton (Müll. Arg.) Pax (Euphorbiaceae s.s.). Biota Neotrop. 8(2): http://www.biotaneotropica.org.br/v8n2/pt/abstract?taxonomicreview+bn01108022008

Resumo: O gênero Croton L. é o segundo maior e mais diverso da família Euphorbiaceae, possuindo cerca de 1.200 espécies, agrupadas em 40 seções, com distribuição pantropical, das quais a maioria ocorre nas Américas. $\mathrm{Na}$ América o Sul, o Brasil é o país que congrega o maior número de espécies, aproximadamente 356. De acordo com a mais recente classificação, o gênero pertence à tribo Crotoneae e, apesar do grande número de espécies e da grande diversidade morfológica, seria um táxon monofilético. Entretanto, uma análise filogenética recente, que utilizou dados moleculares das regiões ITS, do DNA nuclear ribossômico, e do fragmento trnL-F, do DNA plastidial, demonstrou que Croton, como tradicionalmente circunscrito, não é um táxon monofilético. Neste trabalho, é apresentada uma revisão taxonômica de Croton sect. Lamprocroton (Müll. Arg.) Pax. Trata-se de um grupo neotropical com a maioria das espécies ocorrendo nas regiões Sudeste e Sul do Brasil e sul da América do Sul. Seus representantes caracterizam-se por ser plantas arbustivas ou subarbustivas, monóicas ou dióicas, com indumento lepidoto presente em pelo menos parte da folhagem e folhas inteiras e sem glândulas. As flores estaminadas possuem androceu composto por 9 a 16 estames e as flores pistiladas apresentam sépalas iguais ou desiguais no tamanho, pétalas reduzidas ou ausentes e estiletes uma ou duas vezes bífidos. Neste trabalho são reconhecidas 26 espécies na seção sendo três novas para a ciência. Chave de identificação, descrições morfológicas, ilustrações, período fenológico, distribuição geográfica e comentários gerais de cada uma das espécies são apresentados. Quatro táxons foram excluídos de $C$. sect. Lamprocroton por não possuírem os caracteres morfológicos diagnósticos da seção. Quatro espécies não foram incluídas no tratamento taxonômico por falta de informação sobre as mesmas.

Palavras-chave: Croton, Euphorbiaceae, florística, revisão taxonômica. 


\section{Introdução}

\section{O gênero Croton L.}

O gênero Croton L. é o segundo maior e mais diverso da família Euphorbiaceae s.s e pertence à subfamília Crotonoideae, que consiste de cerca de 2400 espécies agrupadas em 67 gêneros e 12 tribos (Webster 1994). Croton conta com mais da metade das espécies da subfamília, cerca de 1.200, que apresentam distribuição pantropical, seguido, em tamanho, por Jatropha ( \pm 185 espécies) e Manihot ( \pm 100 espécies). Uma das sinapomorfias morfológicas mais importantes da subfamília é configuração da exina dos grãos de pólen, denominada de padrãoCroton. Este padrão foi definido por Erdtman (1952) e designa os grãos de pólen que apresentam excrescências triangulares ou mais ou menos circulares em seção transversal da sexina, suportadas por uma camada baculada, baculóide ou esponjosa. Além disso, Croton compartilha com outras linhagens recentes da subfamília Crotonoideae grãos de pólen inaperturados, uma característica incomum entre as angiospermas e uma sinapomorfia da maioria dos táxons da subfamília (Nowicke 1994).

Croton é um bom exemplo de "gênero problema" - grande e taxonomicamente complexo - e por isso tem sido negligenciado em favor de gêneros menores e mais claramente delimitados. Para muitos botânicos e ecólogos Croton tem sido uma incógnita taxonômica. Leon Croizat trabalhou durante muitos anos com o gênero e descreveu mais de 100 novos táxons (Croizat 1940, 1941, 1944 e muitos outros), mas esse autor nunca teve como objetivo produzir uma classificação infragenérica viável e aplicável para o gênero. Talvez esse fato seja devido ao grande tamanho do gênero, à proliferação de nomes e à dificuldade em se acessar as coleções-tipo que se encontram depositadas em diversos herbários do mundo.

Burger \& Huft (1995) postularam que a considerável variação no tamanho e forma das folhas, pubescência, inflorescência e morfologia floral são os fatores que podem tornar a circunscrição taxonômica de espécies individuais bastante difícil. Alguns dos caracteres que contribuem para a diversidade de Croton oferecem oportunidades de pesquisa promissoras quando acoplados a estudos filogenéticos que incluem, por exemplo, um rico arranjo de nectários extraflorais que desenvolvem um papel importante na interação com formigas (Jose \& Inamdar 1989).

Na sua revisão de Croton na Costa Rica, Burger \& Huft (1995) notaram uma dicotomia geral entre espécies amplamente distribuídas e aquelas que apresentam uma distribuição geográfica bastante localizada, localmente endêmicas. Essa dualidade de espécies amplamente distribuídas e endemismos locais é, de fato, a norma para o gênero em muitas áreas dos trópicos. Talvez, o sucesso do gênero Croton em regiões tropicais com vegetação secundária tenha sido um fator chave para sua diversificação evolutiva.

O gênero Croton é particularmente rico em metabólitos secundários como alcalóides, terpenóides e cocarcinógenos. Extratos das espécies popularmente conhecidas como "sangue-de-drago" (Croton lechleri Müll. Arg., entre outras espécies relacionadas) têm sido utilizados por curandeiros "shaman" como remédios antidiarréicos em pacientes com AIDS (Jones 2003). O óleo extraído de Croton tiglium L. é um forte purgante usado no Velho Mundo. Em um recente trabalho onde foram compiladas informações sobre o uso medicinal, a química e a farmacologia das espécies de Croton (Salatino et al. 2007), ficou evidente que o potencial desse gênero é enorme, porém mais estudos químicos e farmacológicos são necessários, dada a magnitude do gênero.

Muitas espécies de Croton crescem, predominantemente, em locais perturbados tais como beira de estradas, margem de rios e clareiras de matas. Essas e outras características ecológicas, como a produção massiva de flores e frutos durante a maior parte do ano, fazem dos membros do gênero candidatos ideais para a restauração de florestas degradadas. Por exemplo, Croton urucurana Spreng., é usada, atualmente, na recuperação de matas ciliares no Sul do Brasil (Carrenho et al. 1997) e de várias outras regiões. A madeira de várias espécies é utilizada na construção de casas e botes, como lenha e em diversos trabalhos de carpintaria (Smith 2002).

De acordo com a classificação de Webster (1994), o gênero pertence à tribo Crotoneae e, apesar do grande número de espécies e da grande diversidade morfológica, seria um táxon monofilético. Entretanto, uma análise filogenética recente, realizada por Berry et al. (2005a), utilizando dados moleculares das regiões ITS, do DNA nuclear ribossômico, e do fragmento trnL-F, do DNA plastidial, demonstrou que Croton, como circunscrito por Webster (1993), não é um táxon monofilético. Segundo Berry et al. (2005a,b), Croton torna-se um grupo monofilético com a inclusão de Moacroton Croizat, um pequeno gênero endêmico de Cuba, e a exclusão de Croton seção Astraea (Klotzsch) Baill., o que resulta no restabelecimento do gênero Astraea Klotzsch. Além disso, um novo gênero monoespecífico recentemente descrito para a tribo Crotoneae, Brasiliocroton P.E. Berry \& Cordeiro, aparece nessas análises como grupo irmão de Croton, do qual difere principalmente por apresentar os estames eretos no botão floral, que em Croton são sempre encurvados, parecendo constituir a única sinapomorfia morfológica deste gigantesco gênero.

Além da recircunscrição do gênero, essas análises filogenéticas, sobretudo a de Berry et al. (2005a), mostraram a necessidade de uma reavaliação da classificação infragenérica de Croton, pois as seções apresentadas por Webster (1993) não se mostraram monofiléticas em sua maioria. Além deste, outros dois trabalhos já propuseram novos limites para as seções do gênero: Gomes (2006) - C. sect. Argyroglossum Baill. e Riina (2006) - C. sect. Cyclostigma Griseb.

O principal objetivo desse trabalho é realizar uma reavaliação da circunscrição de Croton sect. Lamprocroton (Müll. Arg.) Pax, bem como apresentar um estudo detalhado das suas espécies com vistas à sua revisão taxonômica. Tais estudos abrangem revisão histórica para a solução de problemas nomenclaturais, apresentação de chave de identificação, descrições morfológicas, ilustrações, comentários acerca da biologia, fenologia, hábitats preferenciais e distribuição geográfica para as espécies da seção.

\section{Material e Métodos}

Foram analisados cerca de 1.000 espécimes de Croton seção Lamprocroton depositados em 33 herbários, seguindo os métodos tradicionais utilizados em taxonomia vegetal. Abaixo estão listadas as instituições visitadas ou cujas exsicatas foram recebidas por meio de empréstimo. Os acrônimos estão de acordo com Holmgren et al. (1990), exceto para a sigla destacada em negrito, não indexada. O asterisco sobrescrito indica as instituições não visitadas, cujo material foi obtido por meio de empréstimo.

Os materiais analisados eram provenientes dos seguintes herbários: ALCB, B, BHCB, CEN*, CTES, ESA, F, G, HRB, HRCB, HUCS, IAN, IBGE*, ICN, K, LIL, M, MBM, MEXU*, MG, MO, NY, OUPR, P, PACA, RB, SP, SPF, UB*, UEC, W, WIS, WU.

Coletas de material botânico foram realizadas no Brasil e na Argentina, totalizando 18 expedições. Todo material coletado foi depositado no SPF e duplicatas foram distribuídas ao SP, MBM, NY, $\mathrm{RB}$, WIS, entre outros. O material foi coletado e processado segundo as normas usuais sugeridas por Mori et al. (1989).

Nas descrições morfológicas adotou-se a terminologia proposta por Radford et al. (1974) para o indumento e para as formas planas e tridimensionais e, Webster et al. (1996) para os tipos de tricomas. As espécies são apresentadas em ordem alfabética e o tratamento 
taxonômico oferece descrição morfológica e informações gerais sobre a distribuição geográfica, fenologia e hábitats. Os comentários reúnem informações encontradas na literatura, nas fichas das exsicatas e em observações de campo e de laboratório. Na chave de identificação alguns passos apresentam, como informação complementar, referência geográfica para táxons restritos a estados ou países específicos.

\section{Tratamento taxonômico}

Croton L., Sp. Pl.: 1004. 1753. Tipo: Croton aromaticus L. (lectótipo designado por Webster, J. Arnold. Arbor. 48: 354. 1967).

Árvores, arbustos, subarbustos, menos freqüentemente, ervas ou trepadeiras, monóicos ou dióicos, glabros a indumentados; indumento formado por tricomas de vários tipos como simples, estrelados, lepidotos, entre outros. Folhas alternas, às vezes opostas ou verticiladas, simples, pecioladas, inteiras a profundamente lobadas com margem inteira ou de outro tipo; nervação eucamptódroma, broquidódroma, actinódroma, hifódroma ou camptódroma. Estípulas geralmente presentes, algumas vezes pequenas e inconspícuas, persistentes ou decíduas. Glândulas muitas vezes presentes na base da lâmina foliar ou ápice do pecíolo, às vezes na margem da folha e em outros órgãos da planta como estípulas, brácteas e sépalas. Inflorescências terminais, raro axilares, em geral, racemosas (geralmente racemos ou pseudoracemos, neste caso monotirsos onde as címulas laterais são muito contraídas), uni ou bissexuadas, flores pistiladas dispostas na região proximal e flores estaminadas, na região distal do eixo. Brácteas pequenas, persistentes ou decíduas. Flores estaminadas pediceladas, diclamídeas, actinomorfas; sépalas (4-)5(-6), livres; pétalas (4-)5(-6), raro ausentes, iguais ou menores que as sépalas, livres; disco nectarífero inteiro ou dividido em segmentos opostos as sépalas; estames 5 a muitos, filetes livres, inseridos no receptáculo, encurvados no botão, anteras basifixas, introrsas, 2-loculares, rimosas; pistilódio ausente; receptáculo geralmente piloso; grãos-de-pólen 3-celulares, esféricos, inaperturados, com a sexina mais espessa que a nexina, formada por excrescências triangulares, clavadas a circulares (padrão crotonóide). Flores pistiladas sésseis a curtamente pediceladas, monoclamídeas ou diclamídeas, actinomorfas a levemente zigomorfas; sépalas (4-)5-7(-10), livres; pétalas 5, freqüentemente ausentes ou reduzidas; disco nectarífero inteiro ou dividido em segmentos opostos às sépalas, algumas vezes reduzido; gineceu (1-)3(-4)-carpelar, (1-)3(-4)-locular; óvulo 1 por lóculo, placentação axial; estiletes (2-)3(-4), livres ou unidos na porção proximal, inteiros ou ramificados; estaminódios às vezes presentes. Frutos esquizocarpos ou capsulídios, em geral, globosos, 3-lobados; endocarpo crustáceo a lenhoso; columela usualmente persistente, freqüentemente delgada. Sementes na maioria elipsóides, planas na face interna, convexas na externa, endospermadas, com testa lisa a rugosa, carunculadas ou não; embrião reto com cotilédones planos, membranáceos, arredondados, mais largos do que a radícula.

Croton sect. Lamprocroton (Müll. Arg.) Pax, Nat. Pflanzenfam. 3(5):

$40.1890 \equiv$ C. sér. Lamprocroton Müll. Arg. in Mart. \& Eichl., Fl. bras. 11(2): 244. 1873. Tipo: Croton ceanothifolius Baill.

Em 1858, Baillon fez uma proposta de classificação infragenérica para Croton na qual dividiu o gênero em 16 seções separadas, principalmente, pela forma das folhas, tipo de indumento, número de estames, tipo de ramificação dos estiletes, entre outras características. Nesse trabalho, o autor (Baillon 1858) propôs o rebaixamento de alguns gêneros como Ocalia Klotzch, Astraea Klotzch, Barhamia Klotzch, Geiseleria Klotzch, Timandra Klotzch, entre outros, ao nível seccional. Em 1864, no seu trabalho sobre as Euphorbiaceae americanas, Baillon manteve sua classificação anterior e reconheceu 16 seções americanas, distintas pelos mesmos caracteres utilizados no seu trabalho anterior de 1858 .
Em um trabalho posterior, Mueller (1865) reconheceu dez seções para Croton sendo apenas uma - a seção Astraea - coincidente com a classificação anterior, de Baillon (1858). Nesse trabalho (Mueller 1865), foi proposta a seção Decarinium caracterizada, especialmente, por agrupar representantes com sépalas das flores pistiladas desiguais, sendo as duas anteriores distintamente maiores do que as demais. Nesse momento, a seção contava com 12 espécies separadas por conta do tipo de indumento (lepidoto ou não) e pelo tipo de ramificação dos estiletes (apenas bífidos ou mais de uma vez bífidos).

No tratamento de Mueller (1866) para o Prodromus foram ainda reconhecidas as mesmas dez seções no gênero Croton, sendo a seção Decarinium caracterizada por incluir plantas com flores estaminadas com (4-)5 sépalas iguais e com receptáculo piloso e, flores pistiladas com 5(-6) sépalas desiguais, duas anteriores, maiores, e três posteriores, menores, e pétalas ausentes ou pouco desenvolvidas. Assim, a seção passou a contar com 32 espécies divididas em dois grupos informais separados, primeiramente, pela presença ou não de indumento lepidoto. O grupo que incluía os representantes com indumento lepidoto contava com 15 espécies, oito delas descritas por Baillon (1864). As espécies lepidotas da seção Decarinium do trabalho anterior (Mueller 1865) foram mantidas na mesma posição nesse novo trabalho (Mueller 1866), entretanto duas delas $-C$. minarum Müll. Arg. e C. minutiflorus Müll. Arg. - foram sinonimizadas em C. ceanothifolius Baill. e C. gaudichaudii Baill., respectivamente.

Na Flora brasiliensis, Mueller (1873) manteve as mesmas dez seções em Croton sendo que oito delas possuíam representantes no Brasil. Também foi mantida a mesma circunscrição anterior para a seção Decarinium, porém como novidade os antigos grupos informais foram formalizados em duas séries - Lamprocroton e Geiseleria distinguidas pela presença ou não de indumento lepidoto. Deste modo, a série Lamprocroton agrupava táxons com indumento lepidoto ao passo que a série Geiseleria, táxons com outro tipo de indumento.

Assim, em síntese, a série Lamprocroton foi, inicialmente, proposta por Mueller (1873) na Flora brasiliensis e constituía, junto com a série Geiseleria, a seção Decarinium, cuja característica principal era a desigualdade no tamanho das sépalas das flores pistiladas, sendo duas delas maiores e três menores. As duas séries podiam ser distinguidas pelo tipo de indumento presente nos seus representantes, isto é, na série Lamprocroton estavam incluídas as plantas com indumento lepidoto em pelo menos algum de seus órgãos e, na série Geiseleria, plantas sem esse tipo de indumento. Nesse primeiro momento, a série Lamprocroton contava com 18 espécies separadas em dois grupos: o primeiro com representantes que possuíam cada um dos estiletes divididos duas ou mais vezes e, o segundo, contendo as espécies com estiletes divididos uma única vez.

Apesar de o nome "Lamprocroton" ter sido utilizado pela primeira vez na Flora brasiliensis (Mueller 1873) nomeando um grupo formal, a maioria das espécies aí incluídas já haviam sido anteriormente descritas, especialmente por Baillon (1864), no seu trabalho sobre as Euphorbiaceae americanas e, pelo próprio Mueller, no seu trabalho de 1865. As espécies de Baillon (1864) colocadas por Mueller (1873) na série Lamprocroton encontravam-se em outras seções nas quais estavam agrupadas plantas extremamente diferentes entre si quanto ao tipo de indumento, presença de glândulas, número de estames e de ramificações dos estiletes, entre outras características. Tais espécies eram as mesmas do seu trabalho anterior (Mueller 1866), além de quatro espécies novas descritas para o Brasil: C. squamulosus Müll. Arg. e C. puncticulatus Müll. Arg., ambas do Rio de Janeiro; C. itacolumii Müll. Arg., do Pico Itacolomi, na região de Ouro Preto (MG) e C. tenellus Müll. Arg. também de Minas Gerais.

A seção Eucroton caracterizava-se por agrupar espécies com cálice 5-mero, com sépalas iguais tanto nas flores estaminadas quanto nas pistiladas e pétalas das flores pistiladas reduzidas. Dividia-se em 
4 subseções - Cyclostigma, Lasiogyne, Eutropia e Podostachys - separadas, principalmente, por conta do tipo de inflorescência (com ou sem címulas bissexuadas; com ou sem espaço estéril entre a região de flores pistiladas e a de flores estaminadas) e pelo tipo de margem das sépalas das flores pistiladas (reduplicada ou não) (Mueller 1865). De acordo com Mueller (1865), a subseção Eutropia reunia plantas com brácteas unifloras e inflorescências contíguas (sem espaço entre a região de flores estaminadas e pistiladas) e contava com 83 espécies com características morfológicas bastante diversas. No trabalho de 1866, Mueller manteve, basicamente, o mesmo tratamento anterior para a seção Eucroton, mas agora a subseção Eutropia contava com 244 espécies.

Na Flora brasiliensis (Mueller 1873) houve uma mudança na seção Eucroton já que a subseção Cyclostigma foi tratada como uma série da subseção Eutropia e foi criada a nova subseção: Cleodora. Assim, nesse momento a seção Eucroton dividia-se nas subseções Lasiogyne, Eutropia, Podostachys e Cleodora. Vale ressaltar que, apesar do nome "Cyclostigma" ter sido mantido, muitas das espécies incluídas na nova série Cyclostigma não coincidiam com as espécies antes incluídas na subseção Cyclostigma.

A nova subseção, Cleodora, foi dividida em duas séries Argyrocroton e Medea - distinguidas, especialmente, por incluírem representantes com ou sem indumento lepidoto, respectivamente. $\mathrm{Na}$ nova subseção foram agrupadas várias das espécies que se encontravam antes na subseção Eutropia (Mueller 1866). Na série Argyrocroton as espécies eram separadas, principalmente, pelo número de ramificações dos estiletes, presença ou não de glândulas na base da lâmina foliar e tipo de tricoma lepidoto que constituía o indumento.

Pax (1890) e Pax \& Hoffman (1931) propuseram uma nova classificação para o gênero Croton sem, contudo, modificarem as delimitações dos táxons, mas apenas elevando as seções e subseções propostas por Mueller (1866) a subgêneros e seções, respectivamente. Deste modo, foi nesses trabalhos, em especial no primeiro (Pax 1890), que a série Lamprocroton foi elevada à categoria taxonômica de seção do então subgênero Decarinium.

Em 1993, Webster publicou uma proposta de classificação infragenérica para Croton que, apesar de provisória, vem sendo utilizada nos trabalhos referentes ao gênero. Nesse trabalho o autor (Webster 1993), por considerar a classificação muelleriana altamente artificial, aceitou várias das seções propostas por outros autores, como Baillon (1864), reconhecendo 40 seções para o gênero Croton e nenhum subgênero. Na sua sinopse, Webster (1993) tratou "Lamprocroton" com o "status" seccional como sugerido no trabalho de Pax (1890) e reavaliou sua circunscrição. Deste modo, de acordo com a proposta de Webster (1993) a seção Lamprocroton é composta por um grupo de espécies predominantemente sul-americanas que inclui não somente as espécies com estiletes bífidos da série Lamprocroton de Mueller (1873), mas também aquelas com estiletes bífidos, folhas sem glândulas e indumento lepidoto colocadas por Mueller (1873) na série Argyrocroton. Assim, de acordo com Webster (1993) a seção pode ser caracterizada morfologicamente por reunir plantas arbustivas, monóicas ou dióicas, com folhas alternas, inteiras e sem glândulas e com indumento lepidoto em pelo menos parte da folhagem. As inflorescências dos seus representantes são racemosas e terminais, com flores estaminadas portando de 10 a 15 estames e flores pistiladas sésseis a subsésseis, com sépalas iguais ou desiguais, inteiras, pétalas reduzidas ou ausentes e estiletes bífidos.

Berry et al. (2005a) realizaram a primeira análise filogenética do gênero Croton utilizando dados moleculares de dois marcadores: ITS e $t r n L-F$. Nesse trabalho os autores fizeram uma avaliação de algumas das seções reconhecidas por Webster (1993) e concluíram que muitas dessas seções não são grupos monofiléticos e precisam ser recircunscritas. Croton alabamensis E.A. Smith, uma espécie endêmica dos Estados Unidos e que foi tratada por Webster (1993) como um representante da seção Lamprocroton por conta do indumento lepidoto, emergiu no clado mais basal junto com Moacroton, um gênero de Cuba e C. olivaceus Müll. Arg., uma espécie equatoriana, como grupo-irmão das demais espécies de Croton (ver Figura 5 de Berry et al. 2005a). Esse resultado poderia levar a uma interpretação errônea de que a seção Lamprocroton é a mais basal do gênero Croton, porém C. alabamensis parece ter sido incluída na seção equivocadamente por Webster (1993) e, neste trabalho, está sendo proposta a exclusão de $C$. alabamensis da seção Lamprocroton. Vale ressaltar que para um resultado mais confiável outras espécies da seção Lamprocroton devem ser incluídas em uma análise filogenética de Croton.

Propõe-se aqui uma ampliação da circunscrição da seção Lamprocroton, com base em características morfológicas. Então, foram considerados membros dessa seção as espécies subarbustivas a arbustivas, nunca arbóreas, com indumento lepidoto, isto é, cujas escamas apresentam raios laterais unidos em pelo menos $20 \%$ do seu comprimento total, presente ao menos nos ramos e face abaxial das folhas, com androceu composto por 9 a 16 estames e estiletes uma ou duas vezes bífidos.

\section{Chave para identificação das espécies de Croton sect. Lamprocroton (Müll. Arg.) Pax}

1. Face adaxial das folhas glabra.

2. Nervuras secundárias bastante salientes na face abaxial; indumento da face abaxial das folhas formado por tricomas pseudo-lepidotos... 17.1. C. pallidulus var. glabrus

- Nervuras secundárias pouco ou não evidentes na face abaxial; indumento da face abaxial das folhas formado por tricomas lepidototípicos.

3. Folhas estreitamente oblongas a estreitamente elípticas; nervação hifódroma ..... 14. C. linearifolius

- Folhas lanceoladas, ovais, obovais, largamente elípticas a largamente ovais; nervação broquidódroma.

4. Racemos unissexuados; metade distal da face adaxial das sépalas das flores pistiladas tomentosa (tricomas estrelados)

Racemos bissexuados; face adaxial das sépalas das flores pistiladas glabra.

5. Folhas cartáceas, ovais a elípticas; sépalas das flores pistiladas desiguais, variando de ovais a obovais; espécie do Sudeste do Brasil, ocorrendo nos estados de Minas Gerais, Rio de Janeiro e São Paulo 6. C. dichrous

- Folhas coriáceas, largamente elípticas a largamente ovais, raramente obovais; sépalas das flores pistiladas iguais, estreitamente espatuladas; espécie do Sul do Brasil, endêmica do estado do Paraná.

15. C. muellerianus 
- Face adaxial das folhas indumentada.

6. Indumento da face adaxial das folhas formado por tricomas simples.

7. Nervação eucamptódroma, nervuras secundárias bastante salientes na face abaxial; face abaxial das folhas coberta por tricomas estrelado-lepidotos

3. C. ceanothifolius

- Nervação broquidódroma, nervuras secundárias pouco ou não evidentes na face abaxial; face abaxial das folhas coberta por tricomas lepidoto-típicos.

6. C. dichrous

- Indumento da face adaxial das folhas formado por outro tipo de tricoma (estrelado, apresso-estrelado ou lepidoto).

8. Indumento da face adaxial das folhas formado por tricomas estrelados, isto é, com raios laterais totalmente livres entre si.

9. Face adaxial das folhas glabrescente, ou seja, os tricomas caem à medida que a folha se desenvolve; planta exclusiva do México. 12. C. hypoleucus

- Face adaxial das folhas não glabrescente, ou seja, os tricomas são persistentes; plantas exclusivas do Brasil.

10. Margem das folhas levemente revoluta.....

7. C. dusenii

- Margem das folhas plana.

11. Nervuras secundárias salientes na face abaxial das folhas; face abaxial das folhas coberta por tricomas pseudo-lepidotos ou estrelado-lepidotos.

12. Indumento dos ramos ferrugíneo; nervação actinódroma reticulada basal; face abaxial das folhas coberta por tricomas estrelado-lepidotos; sépalas das flores pistiladas elípticas a espatuladas com a face adaxial totalmente tomentosa (tricomas estrelados). 20. C. pseudoadipatus

- Indumento dos ramos creme, dourados a creme-cinéreos; nervação broquidódroma; face abaxial das folhas coberta por tricomas pseudo-lepidotos; sépalas das flores pistiladas ovais com a metade distal da face adaxial tomentosa (tricomas estrelados) 17.2. C. pallidulus var. pallidulus

- Nervuras secundárias pouco ou não evidentes na face abaxial das folhas; face abaxial das folhas coberta por tricomas estrelado-lepidotos ou lepidoto-típicos.

13. Racemos unissexuados; sépalas das flores pistiladas desiguais.

14. Folhas com no máximo 1,0 mm de largura, com face abaxial coberta por tricomas lepidoto-típicos; planta exclusiva do Rio Grande do Sul ..... 21. C. pygmaeus

- Folhas com largura variando de 2,0 a 4,0 mm, com face abaxial coberta por tricomas estrelado-lepidotos; planta ocorrendo na Argentina e Paraguai.

11. C. eskuchei

- Racemos bissexuados; sépalas das flores pistiladas iguais.

15. Face abaxial das folhas com nítidos pontos acastanhados formados pela região central dos tricomas lepidotos; sépalas das flores pistiladas obovais a largamente espatuladas; plantas ocorrendo em Minas Gerais, Espírito Santo, Rio de Janeiro, Paraná e Santa Catarina. 23. C. splendidus

- Face abaxial das folhas cinérea sem pontos acastanhados; sépalas das flores pistiladas espatuladas; espécie conhecida apenas pela coleção-tipo proveniente de uma região de Minas Gerais......

25. C. tenellus

- Indumento da face adaxial das folhas formado por tricomas de outro tipo: apresso-estrelado ou lepidoto, isto é, tricomas cujos raios laterais exibem algum grau de união.

16. Face adaxial das folhas coberta por tricomas apresso-estrelados com raios laterais unidos em ca. de $10 \%$ do comprimento total.

17. Face abaxial das folhas coberta por tricomas estrelado-lepidotos; estames 15 a 16; sépalas das flores pistiladas desiguais; planta ocorrendo em regiões serranas e rochosas, principalmente, na Argentina, mas também no Uruguai e no Brasil (Rio Grande do Sul) ..... 1. C. argentinus

- Face abaxial das folhas coberta por tricomas lepidoto-típicos; estames 11; sépalas das flores pistiladas iguais; planta ocorrendo em áreas de cerrado, apenas no Brasil, endêmica de São Paulo

22. C. serpyllifolius

- Face abaxial das folhas coberta por tricomas lepidotos (pseudo-lepidoto, estrelado-lepidoto ou lepidototípico), com raios laterais unidos em $20 \%$ ou mais do comprimento total.

18. Face adaxial das folhas coberta por tricomas pseudo-lepidotos, com raios laterais unidos em 20 a $30 \%$ do comprimento total. 
19. Folhas elípticas a ovais, sempre mais largas do que 2,0 mm; nervação broquidódroma; sépalas das flores pistiladas iguais, triangulares; planta exclusiva do México..... 8. C. ehrenbergii

- Folhas estreitamente elípticas a estreitamente oblongas, com largura variando de 1,0 a 2,0 mm; nervação hifódroma; sépalas das flores pistiladas desiguais, largamente ovais; planta ocorrendo principalmente na Bolívia e também na Argentina 19. C. perintrincatus

- Face adaxial das folhas coberta por tricomas estrelado-lepidotos ou lepidoto-típicos com raios laterais unidos em mais que $30 \%$ do comprimento total.

20. Face adaxial das folhas coberta por tricomas estrelado-lepidotos com raios laterais unidos em 40 a $50 \%$ do comprimento total.

21. Folhas lineares, lanceoladas a estreitamente elípticas; face abaxial das folhas coberta por tricomas lepidoto-típicos; sépalas das flores pistiladas estreitamente triangulares ..

- Folhas elípticas a ovais; face abaxial das folhas coberta por tricomas estrelado-lepidotos; sépalas das flores pistiladas triangulares, ovais a oblongas.

22. Estames 12; sépalas das flores pistiladas iguais, triangulares, com face adaxial glabra; espécie endêmica do México 8. C. ehrenbergii

- Estames 15 a 16; sépalas das flores pistiladas desiguais, ovais a oblongas, com metade distal da face adaxial tomentosa (tricomas estrelados); espécie endêmica do Brasil, conhecida somente de Santa Catarina. 4. C. chloroleucus

- Face adaxial das folhas coberta por tricomas lepidoto-típicos.

23. Folhas estreitas, com no máximo $1,5 \mathrm{~mm}$ de largura; nervação hifódroma; plantas ocorrendo em regiões de dunas e proximidade de lagoas 9. C. ericoides

- Folhas mais largas que 1,5 mm; nervação broquidódroma; plantas ocorrendo em outros tipos de ambientes.

24. Racemos unissexuados; espécie exclusiva da região Sul do Brasil, dos estados do Paraná, Santa Catarina e Rio Grande do Sul.. 16. C. myrianthus

- Racemos bissexuados; espécies ocorrendo em outros estados do Brasil ou no Paraguai.

25. Sépalas das flores pistiladas iguais, com prefloração imbricada; espécie endêmica da Bahia 13. C. imbricatus

- Sépalas das flores pistiladas desiguais, com prefloração valvar; espécies ocorrendo no Paraguai e no Brasil nos estados de MG, SP, RJ e MS.

26. Estiletes bífidos.

27. Sépalas das flores pistiladas espatuladas a ovais, com 3,0 a 5,0 $\mathrm{mm}$ de comprimento; espécie exclusivamente brasileira ocorrendo em MG, SP e RJ 10. C. erythroxyloides

- Sépalas das flores pistiladas largamente ovais, com 7,0 a 11,0 mm de comprimento; espécie exclusivamente paraguaia

24. C. subcinerellus

- Estiletes bibífidos.

28. Sépalas das flores pistiladas estreitamente espatuladas, com indumento da face adaxial formado por tricomas lepidoto-típicos; espécie exclusivamente paraguaia

18. C. paraguayensis

- Sépalas das flores pistiladas estreitamente oblongas, com indumento da face adaxial formado por tricomas estrelado-lepidotos; espécie exclusivamente brasileira ocorrendo em MG e MS 
Glossário de alguns dos termos utilizados na "Chave para identificação das espécies de Croton sect. Lamprocroton (Müll. Arg.) Pax.”

- tipos de tricomas:

- simples: tricomas não ramificados (Figura 20a);

- estrelado: tricomas com raios laterais livres dispostos em um mesmo plano ou deslocados apenas um pouco para cima e totalmente livres entre si (Figura 20b);

- pseudo-lepidoto: tricomas com raios laterais unidos em 20 a $30 \%$ do seu comprimento total (Figura 20c);

- estrelado-lepidoto: tricomas com raios laterais unidos em 30 a 50\% do seu comprimento total (Figura 20d);

- dentado-lepidoto: tricomas com raios laterais unidos em 50 a $80 \%$ do seu comprimento total;

- lepidoto-típico: tricomas com raios laterais unidos em 80 a $100 \%$ do seu comprimento total (Figuras 20e, f).

- sépalas das flores pistiladas:

- iguais: semelhantes entre si no tamanho;

- desiguais: com tamanhos distintos, em geral, duas maiores e três menores.

- estiletes:

- bífidos: com uma divisão em cada um dos ramos do estilete, o que gera seis regiões estigmáticas;

- bibífidos: com duas divisões em cada um dos ramos do estilete, o que gera 12 regiões estigmáticas.

1. Croton argentinus Müll. Arg., J. Bot.12 (3): 200. 1874. Tipo: 'Argentina, prov. Cordoba, Las Penãs, in silvis montanis in Cerro de San Roque', Lorentz 426 (lectótipo, G!). Remanescente do síntipo original: 'Argentina, prov. Cordoba, Las Penãs, habitat in collibus saxosis', [jan. 1871], Lorentz 288 (G!, K!).

Croton argentinus var. chloropetalus Müll. Arg., J. Bot. 12 (3): 200. 1874. Tipo: [Argentina], [Córdoba], [Las Penãs], [jan. 1871], 'habitat cum forma genuina', Lorentz 288 (holótipo, G!; isótipo, K!).

Figuras 1a-d, 15a.

Subarbustos a arbustos, ca. 50,0 cm, monóicos; caule lepidoto, tricomas pseudo-lepidotos, raios laterais parcialmente unidos (ca. $30 \%$ do comprimento total), raio porrecto ausente, creme, sésseis. Folhas levemente discolores, inteiras, cartáceas, estreitamente elípticas a estreitamente oblongas, ápice agudo a arredondado, base aguda, obtusa a arredondada, margem inteira, lâmina $0,5-1,5 \mathrm{~cm}$ comprimento, 2,0-4,0 mm largura, nervação broquidódroma, nervura primária evidente nas duas faces foliares, nervuras secundárias pouco evidentes na face abaxial, face adaxial tomentosa, tricomas apresso-estrelados, raios laterais parcialmente unidos (ca. 10\% do comprimento total), raio porrecto presente, creme, sésseis, face abaxial lepidota, tricomas estrelado-lepidotos, raios laterais parcialmente unidos (40-50\% do comprimento total), raio porrecto ausente, creme a cinéreos, sésseis; pecíolos 1,0-2,5 mm comprimento Inflorescências racemos bissexuados, 1,5-2,0 cm comprimento, lepidotos, tricomas estrelado-lepidotos, raios laterais parcialmente unidos (40-50\% do comprimento total), raio porrecto ausente, creme-amarelados a creme-esverdeados, sésseis; brácteas inteiras, persistentes, 3,0-5,0 mm comprimento, linear-triangulares, ápice agudo, face abaxial lepidota, tricomas estrelado-lepidotos a dentado-lepidotos, raios laterais parcialmente unidos (50-70\% do comprimento total), raio porrecto ausente, cremeamarelados a creme-esverdeados, sésseis, face adaxial glabra. Flores estaminadas alvas a creme, 3,5-6,0 $\mathrm{mm}$ comprimento; pedicelos ca. 3,0 mm comprimento; sépalas ca. $3,0 \mathrm{~mm}$ comprimento, cartáceas, ovais, ápice agudo, face abaxial lepidota, tricomas estrelado-lepidotos a dentado-lepidotos, raios laterais parcialmente unidos (50-70\% do comprimento total), raio porrecto ausente, creme, sésseis, face adaxial glabra; pétalas 3,5-4,5 mm comprimento, cartáceas, oblanceoladas, ápice agudo, metade proximal da margem vilosa, tricomas simples, alvos, faces abaxial e adaxial glabras; estames 15-16, filetes ca. 4,0 $\mathrm{mm}$ comprimento, filiformes, pubescentes, tricomas simples, alvos a creme, anteras ca. 2,0 mm comprimento, conectivos glabros; receptáculo tomentoso, tricomas simples, alvos; disco 5-lobado. Flores pistiladas esverdeadas, 4,0-5,0 mm comprimento; pedicelos ca. 2,0 mm comprimento; sépalas desiguais, uma menor, ca. 1,5 mm comprimento, duas médias, 3,0-4,0 $\mathrm{mm}$ comprimento, duas maiores, ca. 5,0 mm comprimento, coriáceas, triangulares, ápice acuminado, face abaxial lepidota, tricomas estrelado-lepidotos a dentado-lepidotos, raios laterais parcialmente unidos (50-70\% do comprimento total), raio porrecto ausente, creme, sésseis, metade distal da face adaxial tomentosa, tricomas estrelados, raio porrecto presente, alvos, sésseis; pétalas presentes, reduzidas; disco 5-lobado; ovário lepidoto, tricomas estrelado-lepidotos a dentado-lepidotos, raios laterais parcialmente unidos (50-70\% do comprimento total), raio porrecto ausente, creme-esverdeados, sésseis; estiletes bibífidos, primeira ramificação na base, segunda ramificação na metade distal, lepidotos, tricomas estrelado-lepidotos a dentado-lepidotos, raios laterais parcialmente unidos (50-70\% do comprimento total), raio porrecto ausente, creme, sésseis; regiões estigmáticas 12, glabras. Frutos 5,0-6,0 mm comprimento, 5,0-7,0 mm largura; sementes ca. 4,0 mm comprimento, ca. 3,0 mm largura, elipsóides, testa castanha, lisa.

Distribuição geográfica e hábitats: Croton argentinus ocorre, com mais freqüência, na Argentina, nas províncias de Buenos Aires e Córdoba, geralmente em regiões serranas, rochosas, próximas dos $1.500 \mathrm{~m}$ de altura. Porém, pode ser encontrada também no Uruguai e no Brasil, nesse último, apenas no Rio Grande do Sul, no município de São Borja, em área com vegetação aberta.

Fenologia: Flores foram observadas de outubro a abril e em julho. Espécimes com frutos foram obtidos de novembro a abril e em julho.

Material examinado: Argentina: Buenos Aires: Colon: Sierra Chica, s.d. (fl), W. Lossen s.n. (MO s.n.); id., quebrada do rio Primero, entre Casablanca e Dique San Roque, 26 jul. 1964 (fl, fr), A.T. Hunziquer 17467 (MO). Sierra Chica: vale do rio Primero, próximo de Las Caleras, abr. 1874 (fl, fr), G. Hieronymus 204 (P); 6 out. 1897 (fl), T. Stuckert 3240 (G). Soriano: estancia Germania, jun.-dez. 1874 (fl, fr), P.G. Lorentz 65 (B, G, M, P, W, WU); nov. 1877 (fr), G. Hieronymus s.n. (K s.n.). Córdoba: dez. 1878 (bt), Grisebach s.n. (K); Puerto del Paraiso, 4 abr. 1892 (fl), T. Stuckert 2534 (G). Capilla del Monte: Vale de Punilla, 10 jan. 1947 (fl, fr), M. Villafañe 390 (LIL n.v., W); Tanti, 21 fev. 1948 (fl), A.V. Sota 733 (LIL n.v., $\mathrm{P}, \mathrm{W})$; Sierra Chica, Cerro Uritorco, em frente à Capilla del Monte, elev. ca. 1.500 m, 19 dez. 1950 (fl, fr), A.T. Hunziker 8532 (F); San Salvador, caminho para Los Paredones, próximo de Capilla del Monte, 13 abr. 1951 (fl, fr), A.T. Hunziker 9090 (MO); Sierra Grande, Copina, elev. 1.450 m, 31 dez. 1935 (fl, fr), A. Burkart 7295 (F). Copina: Sierra Achala, 17 out. 1946 (fl), A.T. Hunziker 6959 (MO). La Falda: 30 dez. 1906 (fl), T. Stuckert 16653 (G). Río Primero: estancia San Teodoro, Rio I, 9 fev. 1899 (fl), T. Stuckert 6423 (G); Rio IV, 10 dez. 1908 (fl), T. Stuckert 19430 (G); elev. ca. 1.300 m, 17 out. 1946 (bt), A.T. Hunziker 6953 (K). Santa María: Alta Gracia La Paisanita, 1 jan. 1950 (fl), A.V. Sota 1463 (LIL n.v, W). Santa Rosa de Calamuchita: La Cruz, elev. ca. 850 m, 19-21 fev. 1947 (fl), J. Gutiérrez 97 (P, W). Sierra Achala: rio Tercero, 25 mar. 1876 (fr), G. Hieronymus 205 (P). Sierra del Cordoba: 6 abr. 1904 (fl, fr), T. Stuckert 14157 (G). Villa de Carlos Paz: 17 mar. 1944 (fl), M.L. Cuislobro 87 (LIL n.v., NY). Brasil: Rio Grande do Sul: São Borja: BR 267, entre Ponta Porã e Encruzilhada, 11 abr. 1997 (fl), T.M. Pedersen 16304 (MO). Uruguai, Montevidéo, Santiago Vazquez: Barra de Santa Lucia, 1. abr. 1874 (fl), M. Fruchard 767 (P). 
As folhas de $C$. argentinus são levemente discolores, verdeacinzentadas em ambas as faces, e além disso são relativamente pequenas, não ultrapassando $1,5 \mathrm{~cm}$ de comprimento e densamente distribuídas nos ramos. Esses caracteres são de fácil visualização e, aliados à distribuição geográfica, permitem um reconhecimento relativamente fácil da espécie. Mueller (1873) descreveu uma variedade para C. argentinus, caracterizada como "varietas leviter monstruosa" por conta das folhas maiores; entretanto aqui não foram consideradas variedades para o táxon já que o tamanho das folhas parece ser um caráter frágil, pois folhas com tamanhos variados podem ser observadas em um mesmo indivíduo.

Croton argentinus é bastante semelhante a $C$. pycnocephalus Baill., espécie que ocorre na Argentina e região Sul do Brasil. Croizat (1941) chamou a atenção para o confuso tratamento dado por Grisebach, em 1879 (apud Croizat 1941), na Flora da Argentina, identificando várias coleções de $C$. argentinus como C. pycnocephalus. Vale ressaltar que, em um primeiro momento, é mesmo difícil distinguir os dois táxons já que ambos possuem hábito e flores estaminadas muito semelhantes, porém o indumento da face abaxial das folhas de C. argentinus é composto por tricomas com raios laterais mais unidos em sua extensão do que aqueles observados em C. pycnocephalus. Ademais, enquanto em C. pycnocephalus os estiletes são multífidos, em $C$. argentinus eles são duas vezes bífidos (bibífidos). Outra diferença entre esses dois táxons pode ser observada na face adaxial das pétalas das flores estaminadas, pois enquanto em $C$. pycnocephalus essa região é conspicuamente indumentada, em $C$. argentinus ela é totalmente glabra. Em contrapartida, em C.argentinus, tanto os filetes quanto os estiletes são indumentados. Croton argentinus é, segundo Croizat (1941), estreitamente relacionada à C. paraguayensis Chodat., porém essas espécies são bastante diferentes em diversos aspectos especialmente no tipo de tricoma que constitui o indumento; em C. paraguayensis ele é lepidoto-típico. O hábito, a forma das sépalas das flores pistiladas e o tipo de ramificação dos estiletes são outros caracteres que podem ser utilizados na distinção desses dois táxons.

2. Croton burchellii Müll. Arg. in Mart. \& Eichl., Fl. bras. 11 (2): 139. 1873. Tipo: [Brasil], 'Prov. Goyas, prope Porto Imperial', s.d., Burchell 8631 (holótipo, G!; isótipos, K!, P!; fotografias do holótipo, F!, NY! ex G).

Figuras 1e-h; $15 \mathrm{~b}$.

Subarbustos, 0,5-1,0 m altura, monóicos; caule lepidoto, tricomas lepidoto-típicos, raios laterais parcialmente unidos (ca. de $90 \%$ do comprimento total), raio porrecto ausente, creme, dourados a acastanhados, sésseis. Folhas levemente discolores, cartáceas a subcoriáceas, lineares, lanceoladas, estreitamente oblongas a estreitamente elípticas, ápice agudo, base aguda, margem inteira, lâmina 2,2-6,8 cm comprimento, 0,2-1,2 cm largura, nervação broquidódroma, nervura primária impressa na face adaxial, saliente na abaxial, nervuras secundárias não evidentes nas duas faces foliares, face adaxial lepidota, tricomas estrelado-lepidotos, raios laterais parcialmente unidos (40-50\% do comprimento total), raio porrecto presente, creme a alvos, sésseis a curto-estipitados, face abaxial lepidota, tricomas lepidoto-típicos, raios laterais parcialmente unidos (ca. $90 \%$ do comprimento total), raio porrecto presente, creme a dourados, sésseis; pecíolos 2,0-6,0 mm comprimento Inflorescências racemos bissexuados, 1,0-2,5 cm comprimento, lepidotos, tricomas lepidoto-típicos, raios laterais parcialmente unidos (ca. de $90 \%$ do comprimento total), raio porrecto ausente, creme, dourados a acastanhados, sésseis; brácteas inteiras, persistentes, 0,5-1,0 $\mathrm{mm}$ comprimento, estreitamente triangulares, ápice agudo, face abaxial lepidota, tricomas estrelado-lepidotos, raios laterais parcialmente unidos (40-50\% do comprimento total), raio porrecto ausente, dourados a acastanhados, sésseis, face adaxial glabra. Flores estaminadas alvas a creme, 1,0-2,5 mm comprimento; pedicelos 1,0-2,0 $\mathrm{mm}$ comprimento; sépalas 1,0-2,0 mm comprimento, coriáceas, ovais, ápice agudo, face abaxial lepidota, tricomas lepidoto-típicos, raios laterais parcialmente unidos (ca. $90 \%$ do comprimento total), raio porrecto ausente, creme a dourados, sésseis, face adaxial glabra; pétalas 1,5-2,0 mm comprimento, membranáceas, largamente obovais, ápice truncado a arredondado, ciliado, tricomas simples, alvos, metade proximal da margem vilosa, tricomas simples, alvos, faces abaxial e adaxial glabras; estames (9-)11(-12), filetes 1,0-2,0 mm comprimento, filiformes, glabros, anteras $0,3-0,5 \mathrm{~mm}$ comprimento, conectivos glabros; receptáculo tomentoso, tricomas simples, alvos; disco 5-lobado. Flores pistiladas alvas a creme, 1,5-3,0 mm comprimento; pedicelos 0,5-2,0 mm comprimento; sépalas desiguais, uma menor, ca. 1,5 mm comprimento, duas médias, ca. 2,0 mm comprimento, duas maiores, ca. 2,5 mm comprimento, coriáceas, estreitamente triangulares, ápice acuminado, face abaxial lepidota, tricomas lepidoto-típicos, raios laterais parcialmente unidos (ca. $90 \%$ do comprimento total), raio porrecto ausente, dourados a ferrugíneos, sésseis, face adaxial glabra ou, raramente, com metade distal tomentosa, tricomas estrelados, raio porrecto ausente, alvos, sésseis; pétalas presentes, reduzidas; disco 5-lobado; ovário lepidoto, tricomas lepidoto-típicos, raios laterais parcialmente unidos (ca. $90 \%$ do comprimento total), raio porrecto ausente, dourados, acastanhados a ferrugíneos, sésseis; estiletes bífidos, ramificados desde a base, lepidotos, tricomas estrelado-lepidotos, raios laterais parcialmente unidos (ca. $40 \%$ do comprimento total), raio porrecto ausente, creme, sésseis; regiões estigmáticas 6 , glabras. Frutos 4,0-5,0 mm comprimento, 4,0-5,0 mm largura; sementes ca. 3,0 mm comprimento, ca. 2,5 mm largura, largamente elipsóides, testa castanha a paleácea, rugosa.

Distribuição geográfica e hábitats: Croton burchellii ocorre nos estados de Goiás, Tocantins, Piauí e Maranhão, em regiões de campo cerrado ou cerrado sensu strictu, especialmente em solo arenoso e em altitudes modestas, variando dos 300 aos $450 \mathrm{~m}$ de altura. Pode ser encontrada também próxima a matas de galeria e em áreas rochosas. A coleção-tipo de $C$. burchellii é proveniente de Goiás, porém há um maior número de coleções oriundas do município de Loreto, no estado do Maranhão.

Fenologia: Flores e frutos foram observados de fevereiro a maio.

Material examinado: Brasil: Goiás: Dianópolis: ca. de 29 km da cidade, na estrada para Taipas e Conceição do Norte, $11^{\circ} 38^{\prime} \mathrm{S}$ e $46^{\circ}$ 50' W, elev. ca. 450 m, 11 fev. 1987 (fl, fr), J.R. Pirani et al. 1931 (K, SP, SPF). Monte Alegre de Goiás: $24 \mathrm{~km}$ pela rodovia a sudoeste de Monte Alegre de Goiás, elev. 600 m, 11 mar. 1978 (fl, fr), W.R. Anderson et al. 6827 (F, K, MO, NY). Maranhão: Loreto: Ilha de Balsas, região entre Rios Balsas e Parnaíba, ca. de 1/3 km da casa principal da fazenda Morros, ca. $35 \mathrm{~km}$ ao sul de Loreto, elev. ca. 300 m, 11 maio 1962 (fl, fr), G. Eiten \& L.T. Eiten 4562 (SP); ca. $15 \mathrm{~km}$ ao sul da cidade de Loreto, a poucos metros ao sul da casa principal da fazenda Aldeia, $7^{\circ} 13^{\prime} \mathrm{S}$ e $45^{\circ}$ 4-8' $\mathrm{W}, 12$ abr. 1962 (fl), G. Eiten \& L.T. Eiten 4268-B (MO, NY); Ilha das Balsas, região entre as Balsas e o rio Parnaíba, $35 \mathrm{~km}$ ao sul de Loreto, $7^{\circ} 23^{\prime} \mathrm{S}$ e 45 4' W, 15 fev. 1970 (fl, fr), G. Eiten \& L. Eiten 10609 (K, MO, NY); Ilha das Balsas, região entre as Balsas e Parnaíba, 35 km ao sul de Loreto, algumas centenas de metros a oeste da casa da fazenda Morros, ao longo da trilha para Gigantes, $7^{\circ} 23^{\prime} \mathrm{S}$ e $45^{\circ} 4^{\prime} \mathrm{W}$, elev. 300-350 m, 15 fev. 1970, G. Eiten \& L. Eiten 10791-A (K). Piauí: 1841 (fl), Gardner 2953 (K). Tocantins: Arraias: rodovia Arraias-Paranã, 12 fev. 1994 (fl, fr), G. Hatschbach, M. Hatschbach \& J.M. Silva 60420 (MBM).

Croton burchellii pode ser reconhecida por conta das folhas relativamente estreitas, com largura variando de 0,2 a $1,2 \mathrm{~cm}$, e do indumento de ambas as faces foliares: na face adaxial formado por tricomas estrelado-lepidotos com raios laterais unidos em 40 a $50 \%$ 
do comprimento total e, na face abaxial por tricomas lepidoto-típicos, com raios laterais quase que totalmente unidos. Apesar de folhas estreitas e lanceoladas estarem também presentes em C. linearifolius Müll. Arg. nesta espécie a face adaxial das folhas é glabra. Outra característica típica de $C$. burchellii são as sépalas das flores pistiladas estreitamente triangulares e sempre menores que o ovário. Apesar da nervação das folhas ser broquidódroma, as nervuras secundárias, em geral, não são evidentes nas duas faces foliares, pois ficam quase que totalmente encobertas pelo indumento. Deste modo, em um primeiro momento, a nervação pode parecer do tipo hifódroma, constituída apenas pela nervura principal, porém a observação de diversos materiais não deixa dúvidas acerca do tipo exato de nervação e pode-se perceber que nervuras secundárias estão presentes e que estas se unem na região marginal da folha.

Mueller (1873), ao descrever C. burchellii, classificou-a na seção Eucroton principalmente por conta das sépalas das flores pistiladas iguais, porém a análise de inúmeras flores pistiladas mostrou que há uma leve desigualdade no tamanho das sépalas das flores pistiladas. Na mesma obra Mueller (1873) citou a presença de tricomas estrelados na face abaxial das sépalas das flores pistiladas como característica de $C$. burchellii, porém nos materiais aqui examinados esse caráter não se mostrou constante, ou seja, em geral, as sépalas das flores pistiladas são internamente glabras e apenas em algumas flores pôde-se observar indumento na sua porção distal. Mueller (1873) também descreveu a presença de tricomas lepidotos esparsos na face abaxial das pétalas das flores estaminadas, contudo tal característica não foi observada em nenhum dos materiais aqui analisados.

3. Croton ceanothifolius Baill., Adansonia 4: 295. 1864. Tipo: [Brasil], 'Prov. de Minas-Geraës, dans les capueiras', Saint-Hilaire D-558 (lectótipo, P!; isolectótipo, P!). Remanescente do síntipo original: [Brasi], 'Prov. de Minas-Geräes, ass. comm. sur. les bords de l'Ouro-Preto', Saint-Hilaire B1-227 (P!).

Croton ceanothifolius var. itabirensis Baill., Adansonia 4: 296. 1864. Tipo: 'In Brasil, prov. de Minas-Geräes, ad Rio d'Itabira', oct. 1843, Claussen 14 (lectótipo, P!; isolectótipos, G!, K!, MO!, P!).

Croton minarum Müll. Arg., Linnaea 34: 138. 1865. Tipo: 'Brasil, prov. Minas Geraës', [1864], Claussen s.n. (holótipo, G!; fotografia do holótipo, NY!).

Croton fallax Müll. Arg., Linnaea 34: 137. 1865. Tipo: 'In Brasiliae prov. S. Paul', [1839], Lund s.n. (lectótipo, G!; isolectótipo, F!). Remanescente do síntipo original: 'In Brasiliae prov. S. Paul, s.d., Riedel s.n. (G!). syn. nov.

Croton itacolumii Müll. Arg., in Mart. \& Eichl., Fl. bras. 11 (2): 246. 1873. Tipo: [Brasil], [Minas Gerais], 'in monte Itacolumi', Riedel 407 pr. p. (holótipo, G!; isótipo, K!; fotografia do holótipo, F!). syn. nov.

Figuras 2a-e; $15 \mathrm{c}$.

Arbustos, 0,6-2,0 m altura, monóicos; caule lepidoto, tricomas lepidoto-típicos, raios laterais parcialmente unidos (ca. 90\% do comprimento total), raio porrecto presente, creme a dourados, sésseis. Folhas fortemente discolores, inteiras, cartáceas, elípticas a ovais, ápice agudo a arredondado, mucronulado, base aguda a obtusa, margem inteira, lâmina 0,4-4,3 cm comprimento, 0,3-1,4 cm largura, nervação eucamptódroma, nervuras secundárias broquidódromas, impressas na face adaxial, bastante salientes na abaxial, face adaxial estrigosa, tricomas simples, creme a dourados, face abaxial lepidota, tricomas estrelado-lepidotos, raios laterais parcialmente unidos (40-50\% do comprimento total), raio porrecto presente, creme a dourados, sésseis a curto-estipitados; pecíolos 1,5-9,0 mm comprimento Inflorescências racemos bissexuados, 1,0-3,0 cm comprimento, lepidotos, tricomas dentado-lepidotos, raios laterais parcialmente unidos (ca. de 70\% do comprimento total), raio porrecto presente, dourados, sésseis; brácteas inteiras, persistentes, 1,5-3,5 mm comprimento, estreitamente triangulares, ápice acuminado, face abaxial lepidota, tricomas estrelado-lepidotos, raios laterais parcialmente unidos (40-50\% do comprimento total), raio porrecto presente, dourados, sésseis, face adaxial glabra. Flores estaminadas alvas, creme, paleáceas a amareladas, 2,0-2,8 mm comprimento; pedicelos 1,5-2,0 mm comprimento; sépalas 1,5-1,8 mm comprimento, coriáceas, ovais, ápice agudo, face abaxial lepidota, tricomas lepidoto-típicos, raios laterais parcialmente unidos (ca. de $80 \%$ do comprimento total), raio porrecto presente, dourados, sésseis a curto-estipitados, face adaxial glabra; pétalas ca. 1,5 mm comprimento, cartáceas, oblanceoladas, ápice acuminado, ápice e metade distal da margem ciliados, tricomas simples, alvos, metade proximal da margem vilosa, tricomas simples, alvos, faces abaxial e adaxial glabras; estames 11(-12), filetes 1,0-2,0 mm comprimento, filiformes, pubescentes, tricomas simples, alvos, anteras $0,5-0,8 \mathrm{~mm}$ comprimento, conectivos glabros; receptáculo tomentoso, tricomas simples, alvos; disco 5-lobado. Flores pistiladas alvas, creme, ocráceas, amareladas a esverdeadas, 3,5-4,5 mm comprimento; pedicelos 1,5-2,0 mm comprimento; sépalas desiguais, duas menores, 2,8-3,0 mm comprimento, três maiores, 3,5-4,0 mm comprimento, coriáceas, ovais, ápice agudo, face abaxial lepidota, tricomas estrelado-lepidotos, raios laterais parcialmente unidos (ca. $50 \%$ do comprimento total), raio porrecto presente, creme a dourados, sésseis, metade distal da face adaxial tomentosa, tricomas simples, alvos a creme; pétalas presentes, reduzidas; disco 5-lobado; ovário tomentoso, tricomas estrelados, raio porrecto presente, creme a dourados, sésseis; estiletes bífidos, ramificados desde a base, glabros; regiões estigmáticas 6 , glabras. Frutos ca. $5,0 \mathrm{~mm}$ comprimento, 5,0-6,0 mm largura; sementes 3,5-4,0 mm comprimento, 2,5-3,0 mm largura, elipsóides, testa vinácea, levemente rugosa.

Distribuição geográfica e hábitats: Croton ceanothifolius é endêmica do estado de Minas Gerais onde ocorre em poucos municípios, como Ouro Branco, Ouro Preto e Sabará; desse último há apenas uma coleção, do ano de 1900, sem localidade específica. No primeiro, ocorre na Serra do Ouro Branco e, no segundo, em várias localidades, entre elas a Estação Ecológica do Tripuí, onde é particularmente freqüente, o Morro do Carvalho e próximo ao Pico do Itacolomi. É encontrada, preferencialmente, em altitudes superiores aos $1.000 \mathrm{~m}$, em regiões serranas, em geral, nos diversos tipos de fisionomias de cerrado, como campo cerrado, campo sujo e cerrado sensu strictu, podendo habitar diversos tipos de ambientes, como margens de cursos d'água, bordas de capoeiras e matas, campos úmidos, em solo areno-pedregoso.

Fenologia: Flores foram observadas de janeiro a setembro e frutos em janeiro, fevereiro e agosto.

Material examinado: Brasil: s.d. (fl), Riedel s.n. (G, NY 00504026, P); s.d. (fl), P. Claussen s.n. (W 134035); s.d. (fl), Sellow 1147 (SP). Minas Gerais: 1820 (fl), Steven s.n. (GDC); 1842-1843 (fl), P. Claussen 210 (K). Ouro Branco: Serra do Ouro Branco, 13 set. 1989 (fl), M.G.V. Torquato et al. s.n. (BHCB 17284). Ouro Preto: s.d. (fl), A.C. Campos 986 (OUPR); s.d. (fl), A.C. Campos s.n. (OUPR 2483); s.d. (fl), L. Damazio 1006 (OUPR); Tripuí, s.d. (fl), Martius 854 (G, M); Vila Rica, s.d. (fl), Pohl 1634 (W); 9 abr. 1887 (fl), Schwacke 5480 (RB); Reserva Biológica do Tripuí, 22 jan. 1986 (fl), B. Irgang \& G. Pedralli s.n. (ICN 81157); id., 7 fev. 1893 (fl), A.G. Silva s.n. (OUPR 3553); id., 7 fev. 1893 (fl), L.E. Coelho s.n. (OUPR 3723); id., 13 fev. 1893 (fl, fr), F.L.S. Brandão s.n. (OUPR 3693); id., 13 maio 1894 (fl), A.T. Abreu s.n. (OUPR 4216); 1904 (fl), Schwacke s.n. (BHCB 582); 1904 (fl), Schwacke s.n. (BHCB 3420); Tombador, 11 ago. 1937 (fl, fr), M. Barreto 9114 (BHCB, F); Saramenha, 13 jan. 1942 (fl), M. Magalhães 1060 (BHCB, IAN); Morro da Cruz, 16 jan. 1942 (fl), M. Magalhães 1105 (BHCB, ESA, MBM); Pirite, 13 jan. 1942 (fl, fr), M. Magalhães 1109 (IAN 14570, IAN 104292, IAN 104299); ca. de $3 \mathrm{~km}$ ao sul de Ouro Preto, no Pico do Itacolomi, elev. ca. 1.650 m, 31 jan. 1971 (fl), H.S. Irwin, 
R.M. Harley \& O. Onishi 29495 (B, IAN, K, M, MO, NY); Morro do Carvalho, jul. 1972 (fl), s.c. (OUPR 6115); Reserva Biológica Tripuí, set. 1987 (fl), M. Sobral et al. 5640 (BHCB, G, ICN, MBM, PACA); id., 15 mar. 2004 (fl), L.R. Lima 352 (SP, SPF, WIS). Sabará: 1900 (fl), L. Damazio 107 (G).

Croton ceanothifolius é uma espécie bastante semelhante quanto ao hábito, forma das folhas e tipo de nervação a $C$. pallidulus Baill., entretanto o tipo de indumento da face adaxial das folhas é diferente nessas duas espécies. Em C. ceanothifolius o indumento é constituído por tricomas simples, enquanto em C. pallidulus os tricomas da face adaxial das folhas são estrelados ou a lâmina apresenta essa região glabra. Tal caráter é de muito fácil visualização e bastante útil na distinção entre esses dois táxons. Além disso, sua distribuição geográfica é fortemente alopátrida: C. ceanothifolius ocorre somente no estado de Minas Gerais, enquanto $C$. pallidulus é encontrada, principalmente, na região Sul do Brasil. Apesar do indumento da face adaxial das folhas ser composto, principalmente, por tricomas simples e eretos pode-se notar, algumas vezes, a presença de tricomas estrelados, curtamente estipitados, com raios laterais bastante curtos e raio central longo entre os tricomas simples. Tal fato pode ser observado em algumas coleções como, por exemplo, Coelho s.n. (OUPR 3723). Nesse caso, os tricomas são diferentes daqueles de $C$. pallidulus var. pallidulus (Baill.) L.B. Smith \& S.F. Smith pois apresentam um raio porrecto bastante evidente, com cerca do dobro do tamanho dos raios laterais, ao contrário dos observados em C. pallidulus, em que o raio porrecto é semelhante aos raios laterais.

Croton ceanothifolius foi descrita por Baillon (1864), no seu trabalho sobre as Euphorbiaceae americanas e foi caracterizada, entre outros aspectos, pela face adaxial das folhas "pubescentia rugosa". Para a descrição do táxon, o autor (Baillon 1864) baseou-se em materiais provenientes da região de Ouro Preto, em Minas Gerais. Nesse mesmo trabalho, Baillon (1864) descreveu C. pallidulus, baseado em um material proveniente de São Paulo, caracterizado pela face adaxial das folhas "... parceque tomentosa" e, apesar do autor não especificar o tipo de tricoma, fica claro, comparando-se com outras diagnoses, que se trata de um indumento formado por tricomas estrelados. Mueller (1866) também admite a existência de C. ceanothifolius como espécie distinta de C. pallidulus apontando, como caráter mais claro que distingue os dois táxons, a diferença entre o tipo de tricoma da face adaxial das folhas. Esse autor (Mueller 1866) sinonimizou C. itabirensis Baill. e C. minarum Müll. Arg. sob C. ceanothifolius. O primeiro táxon era, até então, considerado por Baillon (1864) apenas uma variedade. Na Flora brasiliensis, Mueller (1873) continuou mantendo a sua opinião anterior, ou seja, a de considerar $C$. ceanothifolius como distinta de $C$. pallidulus por conta do tipo de indumento e da distribuição geográfica. Aqui essa posição é seguida, ou seja, C. ceanothifolius e C. pallidulus são considerados táxons distintos, sendo tal decisão tomada por conta da facilidade em separar essas espécies com base no tipo de indumento presente na face adaxial das folhas e na distribuição geográfica. Apesar disso vale ressaltar que sua forte semelhança morfológica indica relações provavelmente bastante estreitas entre ambas. Allem (1978) sinonimizou $C$. ceanothifolius em C. migrans Casar $(=C$. splendidus Mart.), entretanto essa proposta não é aqui aceita, uma vez que foram observadas diferenças consideráveis entre essas duas espécies, que podem ser distinguidas mesmo apenas em estado vegetativo por conta, principalmente, do tipo de nervação, forma das folhas e tipo de indumento das duas faces foliares.

4. Croton chloroleucus Müll. Arg., Linnaea 34: 106. 1865. Tipo: 'In Brasilia meridionali’, s.d., Sellow [4299] (holótipo, B †; lectótipo, G!; isolectótipos, NY!, SP!; fotografia do holótipo, F!, NY!).

Croton erythroxyloides var. sordidus Baill., Adansonia 4: 298. 1864. Tipo: 'Brésil, San-Paolo', 1833, Gaudichaud 956 (holotipo, P!).
Figuras 2f-h; $15 \mathrm{~d}$.

Arbustos monóicos: caule lepidoto, tricomas estrelado-lepidotos, raios laterais parcialmente unidos (ca. de 50\% do comprimento total), raio porrecto ausente, acastanhados, sésseis. Folhas levemente discolores, inteiras, cartáceas, elípticas a ovais, ápice acuminado, base aguda, margem inteira, lâmina 2,5-4,0 cm comprimento, 0,5-1,5 cm largura, nervação broquidódroma, evidente nas duas faces foliares, face adaxial lepidota, tricomas estrelado-lepidotos, raios laterais parcialmente unidos (ca. 50\% do comprimento total), raio porrecto ausente, creme a dourados, sésseis, face abaxial lepidota, tricomas estrelado-lepidotos, raios laterais parcialmente unidos (ca. de 50\% do comprimento total), raio porrecto ausente, creme a amarelados, sésseis; pecíolos 2,0-5,0 mm comprimento Inflorescências racemos bissexuados, 1,0-1,5 cm comprimento, lepidotos, tricomas estrelado-lepidotos, raios laterais parcialmente unidos (ca. de $50 \%$ do comprimento total), raio porrecto ausente, acastanhados, sésseis; brácteas inteiras, persistentes, 1,5-2,0 mm comprimento, triangulares, ápice agudo, face abaxial lepidota, tricomas estrelado-lepidotos, raios laterais parcialmente unidos (ca. 50\% do comprimento total), raio porrecto ausente, acastanhados, sésseis, face adaxial glabra. Flores estaminadas 2,0-4,0 mm comprimento; pedicelos 1,0-2,0 mm comprimento; sépalas ca. $2,5 \mathrm{~mm}$ comprimento, cartáceas, ovais, ápice acuminado, face abaxial lepidota, tricomas estrelado-lepidotos, raios laterais parcialmente unidos (ca. de $50 \%$ do comprimento total), raio porrecto ausente, dourados a acastanhados, sésseis, face adaxial glabra; pétalas ca. 2,5 $\mathrm{mm}$ comprimento, membranáceas, espatuladas, ápice arredondado, metade proximal da margem vilosa, tricomas simples, creme, faces abaxial e adaxial glabras; estames 15-16, filetes ca. 3,0 mm comprimento, filiformes, glabros, anteras ca. 1,0 mm comprimento, conectivos glabros; receptáculo tomentoso, tricomas simples, alvos; disco 5-lobado. Flores pistiladas 3,0-4,0 mm comprimento; pedicelos ca. 1,5 mm comprimento; sépalas desiguais, três menores, 2,0-3,0 mm comprimento, duas maiores, 2,5-3,5 $\mathrm{mm}$ comprimento, coriáceas, ovais a oblongas, ápice agudo, face abaxial lepidota, tricomas estrelado-lepidotos, raios laterais parcialmente unidos (ca. de 50\% do comprimento total), raio porrecto ausente, creme a amarelados, sésseis, metade distal da face adaxial tomentosa, tricomas estrelados, raio porrecto presente, creme a dourados, sésseis; pétalas ausentes; disco inteiro; ovário lepidoto, tricomas estrelado-lepidotos, raios laterais parcialmente unidos (ca. de 50\% do comprimento total), raio porrecto ausente, creme a amarelados, sésseis; estiletes bífidos, ramificados desde a base, lepidotos, tricomas estrelado-lepidotos, raios laterais parcialmente unidos (ca. 50\% do comprimento total), raio porrecto ausente, creme a amarelados, sésseis; regiões estigmáticas 6, glabras. Frutos ca. 7,0 mm comprimento, ca. 6,0 mm largura; sementes ca. 4,0 mm comprimento, ca. 3,0 mm largura, elipsóides, testa paleácea, levemente rugosa.

Distribuição geográfica e hábitats: Trata-se de uma espécie conhecida apenas de poucas coleções, uma muito antiga de São Paulo, outras duas mais recentes, de Santa Catarina, onde foi coletada apenas nos municípios de São Joaquim e de Urupema, no primeiro em região campestre e, no segundo, próxima a um riacho.

Fenologia: A escassez de material não permite muitas inferências; flores foram observadas em fevereiro e em dezembro e frutos somente em dezembro.

Material examinado: Brasil: Santa Catarina: São Joaquim: fev. 1954 (fl), J. Mattos s.n. (PACA 60711). Urupema: 27 dez. 1982 (fl, fr), A. Krapovickas \& A. Schinini 38371 (CTES, G, MBM).

Croton chloroleucus apresenta indumento lepidoto, formado por tricomas estrelado-lepidoto em praticamente todos seus órgãos. As folhas dessa espécie são levemente discolores, com face abaxial mais clara onde se pode notar a presença de pontos acastanhados dados pela região central do tricoma que, em geral, é mais escura que as 
demais regiões e pode ser vista a olho nu. Em alguns dos materiais examinados, as folhas estão distribuídas de modo bastante denso, umas bastantes próximas às outras, conferindo à planta uma aparência de filotaxia quase que imbricada.

Croton chloroleucus foi descrita por Mueller (1865) com base em um material proveniente da região meridional do Brasil. Este autor citou a presença de 12 a 18 estames nas flores estaminadas da espécie, no entanto nas coleções aqui examinadas, o androceu é composto por 15 a 16 estames. O autor (Mueller 1865) também comentou que as duas faces foliares são opacas, caráter este que pode ser observado mesmo no material seco. Na Flora brasiliensis, Mueller (1873) classificou C. chloroleucus como pertencente à série Argyrocroton, no grupo cujas espécies possuem estiletes uma única vez bífidos e indumento formado por escamas longamente radiadas, ou seja, com raios laterais não completamente unidos entre si. Neste mesmo trabalho o autor (Mueller 1873) propôs a sinonimização de C. erythroxyloides var. sordidus Baill. em C. chloroleucus, o que é bastante coerente e aceito no presente trabalho.

5. Croton cinerellus Müll. Arg., Linnaea 34: 137. 1865. Tipo: 'In Brasilia meridionali’, s.d., Riedel s.n. (holótipo, B †ं; lectótipo, W!; isolectótipos, $\mathrm{K}$ !, P!; fotografias do holótipo, G!, MO!).

Figuras 3a-e; $15 \mathrm{e}$.

Arbustos, 0,5-1,0 m altura, monóicos; caule lepidoto, tricomas lepidoto-típicos, raios laterais parcialmente unidos (ca. 95\% do comprimento total), raio porrecto ausente, dourados, sésseis. Folhas levemente discolores, inteiras, cartáceas a subcoriáceas, estreitamente elípticas a estreitamente oblongas, ápice agudo a acuminado, base aguda, margem inteira, lâmina 1,5-4,7 cm comprimento, 2,0-5,0 mm largura, nervação broquidódroma, nervura primária impressa na face adaxial, saliente na abaxial, nervuras secundárias não evidentes nas duas faces foliares, face adaxial lepidota, tricomas lepidoto-típicos, raios laterais parcialmente unidos (90-95\% do comprimento total), raio porrecto presente, verde-claro a verde-acinzentados, sésseis, face abaxial lepidota, tricomas lepidoto-típicos, raios laterais parcialmente unidos (90-95\% do comprimento total), raio porrecto ausente, creme a dourados, sésseis; pecíolos 1,0-2,0 mm comprimento Inflorescências racemos bissexuados, 1,5-3,0 cm comprimento, lepidotos, tricomas lepidoto-típicos, raios laterais parcialmente unidos (ca. $90 \%$ do comprimento total), raio porrecto ausente, dourados, sésseis; brácteas inteiras, persistentes, ca. 2,0 mm comprimento, estreitamente triangulares, ápice agudo a acuminado, face abaxial lepidota, tricomas estrelado-lepidotos, raios laterais parcialmente unidos (ca. 50\% do comprimento total), raio porrecto ausente, creme a dourados, sésseis, face adaxial glabra. Flores estaminadas alvas a creme, ca. $3,0 \mathrm{~mm}$ comprimento; pedicelos ca. 1,5 $\mathrm{mm}$ comprimento; sépalas ca. 2,0 mm comprimento, coriáceas, ovais, ápice agudo, face abaxial lepidota, tricomas lepidoto-típicos, raios laterais parcialmente unidos (ca. 90\% do comprimento total), raio porrecto ausente, dourados, sésseis, face adaxial glabra; pétalas ca. 2,5 mm comprimento, cartáceas, estreitamente elípticas, ápice agudo, ápice e metade distal da margem ciliados, tricomas simples, alvos, metade proximal da margem vilosa, tricomas simples, alvos, metade distal da face abaxial lepidota, tricomas lepidoto-típicos, raios laterais parcialmente unidos (ca. 90\% do comprimento total), raio porrecto ausente, creme, sésseis, região proximal da face adaxial tomentosa, tricomas simples, alvos; estames 10-12, filetes 1,5-2,0 mm comprimento, filiformes, pubescentes, tricomas simples, alvos, anteras ca. 1,0 mm comprimento, conectivos pubescentes, tricomas simples, alvos; receptáculo tomentoso, tricomas simples, alvos; disco 5-lobado. Flores pistiladas creme a douradas, 3,5-5,5 mm comprimento; pedicelos ca. 1,5 mm comprimento; sépalas desiguais, duas menores ca. 3,0 mm comprimento, três maiores ca. 3,8 mm comprimento, coriáceas, estreitamente oblongas, ápice agudo, face abaxial lepidota, tricomas lepidoto-típicos, raios laterais parcialmente unidos (ca. 95\% do comprimento total), raio porrecto ausente, creme a dourados, sésseis, metade distal da face adaxial lepidota, tricomas estrelado-lepidotos, raios laterais parcialmente unidos (ca. $40 \%$ do comprimento total), raio porrecto ausente, alvos a creme, sésseis; disco 5-lobado; pétalas ausentes; ovário lepidoto, tricomas lepidoto-típicos, raios laterais parcialmente unidos (ca. $80 \%$ do comprimento total), raio porrecto ausente, creme, sésseis; estiletes bibífidos, primeira ramificação na base, segunda ramificação na extrema porção distal, lepidotos, tricomas lepidoto-típicos, raios laterais parcialmente unidos (ca. 80\% do comprimento total), raio porrecto ausente, alvos a creme, sésseis, regiões estigmáticas 12, glabras. Frutos ca. 5,0 mm comprimento, 4,0-5,0 mm largura; sementes ca. 4,0 mm comprimento, ca. 3,0 mm largura, elipsóides, testa castanho-escura, lisa.

Distribuição geográfica e hábitats: Conhecida de Minas Gerais e Mato Grosso do Sul, Croton cinerellus ocorre, preferencialmente, em regiões de cerrado e cerradão. Foi coletada também em áreas com solo rochoso, em fissuras de rochas calcárias e em regiões alagadas, no Pantanal. No Mato Grosso do Sul ocorre em regiões com cotas altitudinais relativamente baixas variando dos 80 aos $200 \mathrm{~m}$ de altitude. A coleção analisada por Mueller, no protólogo, não possui localidade precisa porém, na Flora brasiliensis (Mueller 1873) o autor cita coleções provenientes de Minas Gerais.

Fenologia: Flores foram observadas janeiro a março e em junho, julho e outubro. Foi analisado apenas um material com fruto, coletado em fevereiro.

Material examinado: Brasil: s.d. (fl), Burchell 5645 (K, P). Mato Grosso do Sul: Aquidauana: Serra da Bodoquena, ca. $150 \mathrm{~km}$ a oeste de Aquidauana, 23 jul. 1977 (fl), P.E. Gibbs et al. 5428 (UEC). Caracol: km 6 da rodovia para Bela Vista, 12 fev. 1993 (fl, fr), G. Hatschbach, A. Schinini \& J.M. Silva 58852 (CTES, G, K, MBM). Miranda: Serra da Bodoquena, $6 \mathrm{~km}$ a sudeste de Guaicurus, 12 jun. 1973 (fl), J.S. Silva 183 (SP). Ponta Porã: Songa Puitã, 29 out. 1986 (fl), T.M. Pedersen 14764 (CTES, G). Selvíria: Fazenda de Ensino e Pesquisa da Unesp, Campus Ilha Solteira, 18 mar. 1985 (fl), M.R. Pereira-Noronha 561 (SP); id., 7 fev. 1991 (fl), O. Tiritan \& M. Paiva. 480 (SP); id., 23 mar. 1991 (fl), O. Tiritan \& M. Paiva 537 (UEC). Minas Gerais: s.d. (st), Riedel s.n. (NY s.n). Ituiutaba: 10 jan. 1956 (fl), A. Macedo 4133 (SP); ca. 7 km de Ituiutaba em direção a Prata, 13 jul. 2000 (fl), V.C. Souza, J.P. Souza \& G.O. Romão 23833 (ESA, SPF). Uberaba: 1849 (fl), A.F. Regnell 1083 (F, G).

Croton cinerellus é bastante semelhante a C. paraguayensis e C. subcinerellus Croizat quanto ao hábito e ao tipo de indumento presente em toda a planta, sendo relativamente difícil distinguir esses três táxons quando apenas em estado vegetativo. As flores pistiladas dessas três espécies também são semelhantes e apresentam as sépalas desiguais no tamanho, porém enquanto em $C$. cinerellus as sépalas são estreitamente oblongas, em $C$. paraguayensis elas são estreitamente espatuladas e, em $C$. subcinerellus, largamente ovais, encobrindo completamente o gineceu. Em geral, as folhas de C. cinerellus são mais estreitas e mais longas do que as encontradas em C. paraguayensis, mas por se tratar de um caráter comparativo é necessária a familiaridade com o grupo para poder ser utilizado.

Croizat (1944) comenta que C. subcinerellus é uma espécie relacionada à $C$. cinerellus, no entanto, na última, o indumento é "mais metálico" e os lobos das sépalas das flores pistiladas menores. A distribuição geográfica pode auxiliar na distinção dos dois táxons, pois C. subcinerellus é endêmica do Paraguai, de regiões serranas e rochosas ao passo que $C$. cinerellus ocorre apenas no Brasil, em áreas pouco elevadas, em geral, de cerrado. De acordo com o protólogo (Mueller 1865), as flores estaminadas de C. cinerellus apresentam androceu constituído por 12 estames. Na Flora brasiliensis (Mueller 
1873), o mesmo autor cita a presença de 11 estames para o androceu de $C$. cinerellus. Aqui, foram observadas desde flores estaminadas com 10, com 11 e com 12 estames.

6. Croton dichrous Müll. Arg., Linnaea 34: 105. 1865. Tipo: 'In Brasilia meridionali’, s.d., Sellow s.n. (holótipo, B†; lectótipo, G!; isolectótipo, SP!; fotografias do holótipo, F!, MO!, SP!, SPF!).

Croton puncticulatus Müll. Arg. in Mart. \& Eichl., Fl. bras. 11 (2): 249. 1873. Tipo: [Brasil], 'Habitat prope Rio de Janeiro', [Pico do Andarahy Grande à Tijuca], [fev.-mars. 1871], Glaziou 2710 (lectótipo, P!; isolectótipo, P!). Remanescentes dos síntipos originais: [Brasil], 'Habitat prope Rio de Janeiro', Glaziou 891, 2710 (G!). [Brasil], 'Habitat prope Rio de Janeiro', Glaziou 891 (P!). syn. nov.

\section{Figuras 3f-j; $15 f$.}

Subarbustos a arbustos, 0,3-2,5 m altura, monóicos; caule lepidoto, tricomas lepidoto-típicos, raios laterais parcialmente unidos (90-95\% do comprimento total), raio porrecto ausente, creme, dourados a ferrugíneos, sésseis. Folhas fortemente discolores, inteiras, cartáceas, elípticas a ovais, ápice agudo, arredondado a acuminado, mucronulado, base aguda a arredondada, margem inteira, lâmina 1,1-5,5 cm comprimento, 0,5-2,1 cm largura, nervação broquidódroma, nervura primária impressa na face adaxial, saliente na abaxial, nervuras secundárias pouco evidentes na face adaxial, pouco ou não evidentes na face abaxial, face adaxial glabra a, raramente, estrigosa, tricomas simples, alvos a creme ou lepidota, tricomas estrelado-lepidotos, raios laterais parcialmente unidos (ca. $50 \%$ do comprimento total), raio porrecto presente, alvos a creme, sésseis, face abaxial lepidota, tricomas lepidoto-típicos, raios laterais parcialmente unidos (80-90\% do comprimento total), raio porrecto ausente, creme, dourados a cinéreos, sésseis; pecíolos $0,2-1,0 \mathrm{~cm}$ comprimento Inflorescências racemos bissexuados, 0,8-4,0 cm comprimento, lepidotos, tricomas lepidoto-típicos, raios laterais parcialmente unidos (90-95\% do comprimento total), raio porrecto ausente, creme a dourados, sésseis; brácteas inteiras, persistentes, 1,0-3,0 mm comprimento, lanceoladas a estreitamente triangulares, ápice agudo, face abaxial lepidota, tricomas lepidoto-típicos, raios laterais parcialmente unidos (90-95\% do comprimento total), raio porrecto ausente, creme a dourados, face adaxial glabra. Flores estaminadas alvas a creme, 1,5-3,0 $\mathrm{mm}$ comprimento; pedicelos 1,0-2,0 mm comprimento; sépalas 1,5-2,0 mm comprimento, coriáceas, ovais, ápice agudo, face adaxial lepidota, tricomas lepidototípicos, raios laterais parcialmente unidos (ca. 90\% do comprimento total), raio porrecto ausente, creme a dourados, sésseis, face adaxial glabra; pétalas 2,2-3,0 mm comprimento, cartáceas, espatuladas, ápice arredondado, ápice e metade distal da margem ciliados, tricomas simples, alvos, metade proximal da margem vilosa, tricomas simples, alvos, face abaxial lepidota, tricomas lepidoto-típicos, raios laterais parcialmente unidos (ca. 90\% do comprimento total), raio porrecto ausente, alvos a creme, sésseis, face adaxial glabra; estames (10-)11(-12), filetes ca. 1,5 mm comprimento, filiformes, pubescentes, tricomas simples, alvos, anteras ca. $0,5 \mathrm{~mm}$ comprimento, conectivos glabros; receptáculo tomentoso, tricomas simples, alvos; disco 5-lobado. Flores pistiladas alvas, creme, creme-esverdeadas a creme-amareladas, 2,5-5,0 mm comprimento; pedicelos 0,8-3,0 mm comprimento; sépalas desiguais, duas menores 2,0-2,5 mm comprimento, três maiores 3,0-4,0 mm comprimento, coriáceas, ovais a obovais, ápice agudo, face abaxial lepidota, tricomas lepidoto-típicos, raios laterais parcialmente unidos (ca. de $90 \%$ do comprimento total), raio porrecto ausente, creme a dourados, sésseis, face adaxial glabra; pétalas presentes, reduzidas; disco inteiro; ovário lepidoto, tricomas lepidoto-típicos, raios laterais parcialmente unidos (ca. de 90\% do comprimento total), raio porrecto ausente, creme a dourados, sésseis; estiletes bífidos, ramificados desde a base, glabros a lepidotos apenas na região proximal, tricomas lepidoto-típicos, raios laterais parcialmente unidos (ca. de $90 \%$ do comprimento total), raio porrecto ausente, creme a dourados, sésseis, regiões estigmáticas 6, glabras. Frutos 5,0-6,0 mm comprimento, 4,5-6,0 mm largura; sementes ca. 3,5 mm comprimento, ca. 2,5 mm largura, elipsóides, testa vinácea a atro-acastanhada, lisa a levemente rugosa.

Distribuição geográfica e hábitats: Croton dichrous foi coletada somente na região Sudeste do Brasil, nos estados de São Paulo, Rio de Janeiro e Minas Gerais. Ocorre em diversos tipos de ambientes como campo, campo sujo, campo rupestre e capão de mata, nesse caso, especialmente em clareiras. Também foi coletada junto a cursos d'água. No município de Campos do Jordão, em São Paulo, é encontrada nas Matas de Araucária e em Queluz, foi coletada apenas uma vez em local com vegetação herbácea e subarbustiva, sobre rochas, na região da Pedra da Mina, próxima dos $2.770 \mathrm{~m}$ de altura. No Rio de Janeiro parece ocorrer apenas no Parque Nacional de Itatiaia, em regiões rochosas, com baixa drenagem. Está sempre associada a localidades com altitudes elevadas, superiores aos $1.000 \mathrm{~m}$, podendo ser encontrada em regiões com elevações superiores aos $2.500 \mathrm{~m}$ de altura.

Fenologia: Flores foram encontradas o ano inteiro, exceto no mês de julho. Frutos foram observados em março, maio, junho e outubro.

Material examinado: Brasil: Minas Gerais: Camanducaia: Monte Verde, Pedra do Selado, 15 maio 2001 (fl), L.D. Meireles et al. 293 (SP, UEC); id., 28 jun. 2001 (fl), L.D. Meireles \& R. Belinello 339 (SP); id., Pedra Redonda, 13 jul. 2004 (fl), M.B.R. Caruzo \& D.A. Ferro 59 (SP, WIS); id., Rua do Aeroporto (rua de terra), 14 jul. 2004 (fl), M.B.R. Caruzo \& D.A. Ferro 60 (SP, WIS); id., Rua do Aeroporto (rua de terra), 14 jul. 2004 (fl), M.B.R. Caruzo \& D.A. Ferro 61 (SP); id., Rua do Aeroporto (rua de terra), 14 jul. 2004 (fl, fr), M.B.R. Caruzo \& D.A. Ferro 62 (SP); id., Av. as Montanhas, além da caixa d'água da COPASA, 14 jan. 206 (fl), M. Kirizawa \& C.C. Xifreda 3518 (SP). Córrego do Bom Jesus: Serra de São Domingos, elev. 2.050 m, 29 mar. 1999 (fl), J.R. Stehmann et al. 2504 (BHCB). Rio de janeiro: Campos da Bocaina, 7 set. 1879 (fl), M.A. Glaziou 11550 (K, P); Serra da Bocaina, mar. 1963 (fl, fr), A.P. Duarte 7691 (RB, SPF). Itatiaia: s.d. (fl), H. Luederwaldt s.n. (SP 13726); Campos de Itatiaia, 1873 (fl), M.A. Glaziou 6681 (G, K, P); 1879 (fl), H. Wawia 388 (W); Serra do Itatiaia, elev. 2.100 m, 31 out. 1906 (fl), P. Dusén 102 (K); Serra do Itatiaia, elev. 2.400 m, 4-10 jun. 1913 (fl), T. Tamandaré \& A.C. Brade 6364 (SP); Serra do Itatiaia, elev. 2.400 m, jun. 1913 (fl), T. Toledo \& A.C. Brade 696 (RB); 20 out. 1922 (fl), P.C. Porto s.n. (MG 49542, RB 20759); id., Agulhas Negras, elev. ca. 2.300m, 22 out. 1927 (fl), A. Ginzberger \& H. Zerny s.n. (W 9388); id., base das Agulhas Negras, 23 out. 1931 (fl), P.C. Porto 2091 (RB); Prateleiras, 18 jan. 1935 (fl), P.C. Porto 2687 (B, RB); Rio das Flores, 31 jan. 1935 (fl), P.C. Porto 2715 (B, RB); Rio d'Ouro, 1 fev. 1935 (fl), P.C. Porto 2739 (B, RB); 16 jan. 1936 (fl), L. Laustyac s.n. (RB 93546); Agulhas Negras, elev. 2.500 m, 22-28 nov. 1938 (fl), Markgrat \& A.C. Brade 3696 (RB); 29 abr. 1949 (fl, fr), E. Kuhlmann s.n. (SP 75857); Parque Nacional do Itatiaia, elev. ca. 1.800 m, set.-out. 1958 (fl), W. Schwabe s.n. (B 100086890); id., ca. 1.800 m, set.-out. 1958 (fl), W. Schwabe s.n. (B 100086892); elev. 2.000-2.200 m, 13 abr. 1963 (fl), E. Pereira \& C. Pereira 7574 (NY); id., $200 \mathrm{~m}$ a sudeste do Abrigo Rebouças, $22^{\circ} 25-26^{\prime} \mathrm{S}$ e $44^{\circ}$ 41-42'W, elev. 2.300 m, 3 nov. 1965 (fl), G. Eiten \& L.T. Eiten 6558 (K, NY, SP); id., km 12 ao longo da estrada que leva ao Abrigo Rebouças, 22 ${ }^{\circ} 25^{\prime} \mathrm{S}$ e $44^{\circ} 42^{\prime} \mathrm{W}$, elev. $2.250 \mathrm{~m}$, 6 nov. 1965 (fl, fr), G. Eiten \& L.T. Eiten 6676 (K, NY, SP); id., elev. 2.450 m, 18 dez. 1968 (fl), H. Merxmüller 255776 (M);id., Agulhas Negras, elev. ca. 2.400 m, 27 maio 1969 (fl), D. Sucre \& T. Plowmann 2835 (RB); Agulhas Negras, elev. ca. 2.400 m, 30 maio 1969 (fl, fr), T. Plowman 2835 (K); Serra da Mantiqueira, na estrada entre Itatiaia e São Lourenço para Agulhas Negras, elev. 2.100 m, 6 set. 1973 (fl), 
F. Ehrendorfer \& G. Gottsberger 73906-26 (SP); Prateleiras, elev. 2.300 m, 24 maio 1975 (fl), A.M. Cameril 26 (K); Parque Nacional do Itatiaia, planalto próximo ao Abrigo Rebouças, elev. ca. 2.200 m, 6 nov. 1976 (fl), G. Martinelli et al. 1078 (RB); id., Pico das Agulhas Negras, elev. 2.350 m, 29 abr. 1977 (fl), M.S.F. Silvestre 83 (SP); id., abrigo Rebouças, elev. 2.300 m, 11 out. 1977 (fl), P.J. Maas \& G. Martinelli 3191 (RB); id., ao longo da estrada para Agulhas Negras, $22^{\circ} 25^{\prime} \mathrm{S}$ e $44^{\circ} 40^{\prime} \mathrm{W}$, elev. 2.000-2.600 m, 18 out. 1977 (fl), L.R. Landrum 2109 (RB); id., ao longo da estrada para Agulhas Negras, ca. $22^{\circ} 25^{\prime} \mathrm{S}$ e $44^{\circ} 40^{\prime} \mathrm{W}$, elev. 2.000-2.600 m, 18 out. 1977 (fl, fr), L.R. Landrum 2125 (RB); id, estrada para Prateleiras, próximo do abrigo Rebouças, 4 jun. 1978 (fl), H.P. Bautista \& V.M. Schettino 292 (HRB, MG); id., estrada para Agulhas Negras, 18 jan. 1979 (fl), P. Occhioni 8682 (MBM); id., próximo ao abrigo Rebouças, elev. 2.400 m, 9 out. 1981 (fl), G. Martinelli et al. 7763 (RB); id., Agulhas Negras, 2 dez. 1983 (fl), A. Furlan \& Cesar 130 (HRCB); id., estrada em direção as Prateleiras, 5 out. 1991 (fl), S.A. Nicolau 234 (SP, SPF). São Paulo: Serra da Bocaina, set. 1879 (fl), L. Damazio s.n. (RB 82951); id., elev. 1650 m, 22 abr. 1951 (fl), A.C. Brade 20681 (RB). Campos do Jordão: Parque Estadual de Campos do Jordão, s.d. (fl), J. Mattos 16356 (NY, SP, SPF); 5-20 fev. 1937 (fl), P.C. Porto 2973 (RB); 22 out. 1938 (fl), G. Hashimoto 39 (SP); Umuarama, 22 nov. 1949 (fl), E. Kuhn \& M. Kuhlmann 2058 (SP); arredores do Pico de Itapeva, 23 maio 1957 (fl), G.F.J. Pabst 4200 (RB); Parque Estadual de Campos do Jordão, 23 out. 1974 (fl), J. Mattos 15941 (SP); id., perto da sede, 30 out. 1974 (fl), J. Mattos 16197 (SP); estrada desde Monteiro Lobato, perto do Hotel Toriba, 28 set. 1976 (fl), P.H. Davis et al. 2963 (RB, UEC); Parque Estadual de Campos do Jordão, 26 jul. 1985 (fl), M. Kirizawa \& M. Sugiyama 1499 (SP); Morro do Elefante, 23 maio 1991 (fl), M.J. Robim et al. 699 (SP, SPSF n.v.); Parque Estadual, trilha do rio Sapucaí, 24 jun. 1991 (fl), S. Xavier \& E. Caetano 110 (MBM, SP, SPSF n.v.); id., trilha do rio Sapucaí, 7 jun. 1992 (fl), E. Martins et al. 26486 (UEC); Pico do Itapeva, 9 jun. 1992 (fl), K. Yamamoto et al. 26726 (UEC); id., 9 jun. 1992 (fl, fr), K. Yamamoto et al. 26727 (UEC); id., 9 jun. 1992 (fl), K. Yamamoto et al. 26744 (UEC); Morro do Elefante, 10 jun. 1992 (fl, fr), R. Godenberg et al. 26418 (UEC); id., 15 out. 1992 (fl), S. Xavier et al. 310 (SP, SPSF n.v.); Salto, 25 ago. 1993 (fl), K.D. Barreto, G.D. Fernandes \& F.X. Vitti 1069 (ESA, HUEFS n.v., MBM, UNIP n.v.); Parque Estadual dos Mananciais, 5 set. 1994 (fl), M.J. Robim \& S. Aragaki 794 (SP, SPSF n.v.); Parque Estadual de Campos do Jordão, trilha do rio Sapucaí, $22^{\circ} 41^{\prime} 20^{\prime \prime} \mathrm{S}$ e $45^{\circ} 28^{\prime} 60^{\prime}$ W, elev. $1.620 \mathrm{~m}, 27 \mathrm{fev} .2002$ (fl), I. Cordeiro et al. 2771 (SP, SPF); id., 29 out. 2003 (fl), L.R. Lima \& P.M. S. Rosa 320 (SP, SPF, WIS); estrada para São José doas Alpes, 25 out. 2004 (fl), M.B.R. Caruzo \& S.E. Martins 69 (SP, SPF, WIS). Cruzeiro: limite entre os estados de São Paulo e Minas Gerais, alto do Pico Itaguaré, elev. 2.400 m, 4 jun. 1995 (fl), L.R. Parra et al. 10 (SP, SPF). Pindamonhangaba: alto de São José dos Alpes, Usina Isabel, elev. 1.960 m, 29 mar. 1994 (fl), L. Rossi et al. 1452 (ESA, HRCB, RB, SP, SPF, UEC). Queluz: Pedra da Mina, $22^{\circ} 25^{\prime} 41^{\prime}$ " S e 44 50' 34” W, elev. 2.770 m, 19 fev. 1997 (fl), G.J. Shepherd et al. 97-79 (HRCB, SPF, UEC). São José do Barreiro: Serra da Bocaina, elev. 1.770 m, 29 maio 1958 (fl), O. Handro 781 (NY, SP, SPF); Reserva Florestal da Bocaina, elev. 1.600-1.700 m, 8 maio 1968 (fl), D. Sucre 3061, P.T.T. Braga 778 \& D.J. Guimarães (RB); Parque Nacional da Bocaina, fazenda Floresta, elev. 1.560 m, 16 jul. 1994 (fl), L. Rossi \& E.L.M. Catharino 1547 (RB, SP, SP, SPF, UEC); id., fazenda Floresta, 23 jan. 1996 (fl), H. Longhi-Wagner et al. 3001 (SP, UEC); id., 26 dez. 1997 (fl), L. Freitas \& I.S. Martin-Gajardo 15 (UEC); id., 26 dez. 1997 (fl), L. Freitas \& I.S. Martin-Gajardo 16 (SP, UEC); id., 26 dez. 1997 (fl), L. Freitas \& I.S. Martin-Gajardo 17 (UEC); id., morro à esquerda da guarita do IBAMA, 17 mar. 1999 (fl, fr), L. Freitas 619 (ESA, SP).
Croton dichrous pode ser distinguida das demais espécies da seção por conta, principalmente, das folhas fortemente discolores com a face adaxial, em geral, completamente glabra, entretanto, quando jovem, a face adaxial pode apresentar tricomas simples que caem à medida que a folha se desenvolve, fato que foi observado, exclusivamente, nos materiais provenientes da região de Itatiaia, no Rio de Janeiro. As características listadas acima como diferenciais de $C$. dichrous podem ser observadas em C. muellerianus L.R. Lima, o que faz com que haja uma confusão na delimitação dos dois táxons e que se reflete nas identificações observadas nos herbários. No entanto, as duas espécies podem ser diferenciadas pela textura e formato das folhas, em geral cartáceas e variando de ovais a elípticas em $C$. dichrous e, coriáceas, variando de largamente ovais a largamente elípticas em C. muellerianus. Além disso, enquanto na primeira as sépalas das flores pistiladas são desiguais, no tamanho, e ovais ou obovais, na segunda elas são iguais e estreitamente espatuladas. Também na distribuição geográfica elas estão separadas: $C$. muellerianus é endêmica do estado do Paraná, ao passo que $C$. dichrous ocorre somente na região Sudeste do Brasil, nos estados de São Paulo, Rio de Janeiro e Minas Gerais.

As populações de $C$. dichrous provenientes de cada um dos estados supracitados parecem apresentar características próprias. Os espécimes coletados no Rio de Janeiro apresentam folhas elípticas, com ápice agudo, densamente distribuídas nos ramos e com a face adaxial, muitas vezes, possuindo tricomas simples, sendo essa característica observada somente nos indivíduos provenientes do Parque Nacional do Itatiaia. As coleções de Minas Gerais assemelham-se muito às do Rio de Janeiro exceto por terem sempre a face adaxial das folhas glabras. As coleções de São Paulo também possuem a face adaxial das folhas glabras, mas apresentam as folhas, em geral, mais ovais, com ápice acuminado, distribuídas menos densamente nos ramos e com face abaxial extremamente prateada. Talvez, tenha sido essa variação populacional o principal motivo que levou Mueller (1873) a descrever uma nova espécie, C. puncticulatus, baseado em materiais provenientes do Rio de Janeiro, entretanto aqui esses dois táxons são considerados sinônimos.

7. Croton dusenii Croizat, J. Arnold. Arbor. 21: 106. 1940. Tipo: [Brasil], [Santa Catarina], 'Paraná, Calmon in subpaludosis', [15. mar.] 1910, Dusén 9265 (holótipo, A; isótipos, F 839916!, G!, MO!; fotografia do holótipo na web, A 47286!).

Figuras 4a-e; 16a.

Subarbustos a arbustos, 0,2-1,0 m altura, monóicos; caule lepidoto, tricomas lepidoto-típicos, raios laterais parcialmente unidos (ca. $80 \%$ do comprimento total), raio porrecto presente, creme, dourados a acastanhados. Folhas levemente discolores, inteiras, cartáceas, elípticas, obovais, oblanceoladas a estreitamente oblongas, ápice agudo, obtuso a arredondado, base aguda, margem inteira, levemente revoluta, lâmina 0,6-1,5 cm comprimento, 2,0-6,0 mm largura, nervação broquidódroma, nervura primária impressa na face adaxial, saliente na abaxial, nervuras secundárias pouco evidentes nas duas faces foliares, face adaxial tomentosa, tricomas estrelados, raio porrecto presente, creme a dourados, sésseis a curto-estipitados, face abaxial lepidota, tricomas estrelado-lepidotos, raios laterais parcialmente unidos (ca. $40 \%$ do comprimento total), raio porrecto presente, creme a dourados, sésseis; pecíolos 1,0-2,5 mm comprimento Inflorescências racemos unissexuados, 0,8-2,0 cm comprimento, lepidotos, tricomas lepidototípicos, raios laterais parcialmente unidos (ca. $80 \%$ do comprimento total), raio porrecto presente, creme, dourados a acastanhados, sésseis; brácteas inteiras, persistentes, 3,0-4,0 mm comprimento, estreitamente triangulares, ápice agudo a acuminado, face abaxial lepidota, tricomas lepidoto-típicos, raios laterais parcialmente unidos (ca. $80 \%$ do comprimento total), raio porrecto presente, creme, 
sésseis, face adaxial glabra. Flores estaminadas creme a amareladas, 2,0-3,5 mm comprimento; pedicelos 1,0-3,0 mm comprimento; sépalas 1,5-2,0 mm comprimento, coriáceas, ovais, ápice agudo a acuminado, face abaxial lepidota, tricomas lepidoto-típicos, raios laterais parcialmente unidos (ca. $80 \%$ do comprimento total), raio porrecto presente, creme a dourados, sésseis, face adaxial glabra; pétalas ca. 2,0 mm comprimento, membranáceas, estreitamente oblongas, ápice arredondado, ciliado, tricomas simples, alvos, metade proximal da margem vilosa, tricomas simples, alvos, faces abaxial e adaxial glabras; estames 10-11, filetes 2,0-2,5 mm comprimento, filiformes, glabros, anteras $0,5-1,0 \mathrm{~mm}$ comprimento, conectivos glabros; receptáculo tomentoso, tricomas simples, alvos, alvos; disco 5-lobado. Flores pistiladas creme, 3,0-4,0 mm comprimento; pedicelos 2,0-3,5 mm comprimento; sépalas iguais, 2,5-3,0 $\mathrm{mm}$ comprimento, coriáceas, ovais, ápice agudo, face abaxial lepidota, tricomas estrelado-lepidotos, raios laterais parcialmente unidos (ca. $40 \%$ do comprimento total), raio porrecto presente, creme a dourados, sésseis, metade distal da face adaxial tomentosa, tricomas simples, alvos; pétalas presentes, reduzidas; disco 5-lobado; ovário lepidoto, tricomas estrelado-lepidotos, raios laterais parcialmente unidos (ca. $40 \%$ do comprimento total), raio porrecto presente, creme a dourados, sésseis; estiletes bífidos, ramificados desde a base, glabros; regiões estigmáticas 6, glabras. Frutos não observados.

Distribuição geográfica e hábitats: Croton dusenii é endêmica do estado de Santa Catarina, onde ocorre em regiões de campos alagados. Segundo Smith et al. (1988), trata-se de uma espécie heliófila e seletiva higrófila pouco freqüente e pode ser encontrada, preferencialmente, nos banhados dos campos e orla dos capões situados em solos úmidos. Segundo esses mesmos autores, C. dusenii formaria, algumas vezes, pequenos agrupamentos juntamente com C. pallidulus e C. tenuissimus. Porém isso não foi aqui observado e $C$. dusenii parece ser sempre alopátrida em relação a essas duas espécies. Ocorre simpatridamente com C. splendidus na Serra do Quiriri, no município de Campo Alegre.

Fenologia: Flores foram observadas em fevereiro, abril, setembro e outubro, mas talvez, esse pequeno período fenológico seja reflexo do baixo número de coleções disponíveis. Não foram analisados materiais com fruto.

Material examinado: Santa Catarina: Caçador: Fazenda dos Carneiros, elev. 1.100 m, 28 out. 1962 (fl), R. Reitz \& R.M. Klein 13775 (NY); id., 28 out. 1962 (fl), R. Reitz \& R.M. Klein 13779 (MBM). Calmon: arredores da cidade, 14 abr. 2004 (fl), L.R. Lima \& J.M. Silva 355 (MBM, SP, SPF). Campo Alegre: Serra Quiriri, elev. 1.350 m, 29 set. 2001 (fl), O.S. Ribas et al. 3655 (MBM, SPF). Porto União: entre Matos Costa e Calmon (22 km), elev. 900-1.100 m, 5 fev. 1957 (fl), L.B. Smith \& R. Klein 10854 (K, NY).

Croton dusenii pode ser distinguida das demais espécies da seção Lamprocroton, pois possui as folhas com margem levemente revoluta, caráter exclusivo desse táxon. Além disso, as folhas são relativamente pequenas e densamente distribuídas nos ramos. Outra característica que pode auxiliar na identificação de $C$. dusenii é a forma das folhas que, em geral, são mais largas acima da metade do seu comprimento, variando de oblanceoladas a obovais. As inflorescências são pequenas, paucifloras e ficam quase que totalmente encobertas pelas folhas terminais.

Allem (1978) considerou C. dusenii como um sinônimo de C. migrans alegando que esses dois táxons expressam apenas variações no hábito e que a morfologia floral e dos frutos é a mesma, entretanto a forma das folhas, disposição dessas nos ramos e tipo de indumento são bastante distintos e possibilitam a separação, de modo relativamente fácil, dessas duas espécies. De acordo com Croizat (1940), C. dusenii assemelha-se, quanto aos caracteres florais, a $C$. argentinus e $C$. serpyllifolius Baill., duas outras espécies da seção Lamprocroton, porém pode ser distinta de ambas por meio da forma, margem e indumento das folhas. Segundo Croizat (1940) o hábito de $C$. dusenii é muito semelhante ao de $C$. pycnocephalus e $C$. tartonraira Müll. Arg., entretanto novamente a distinção entre esses táxons pode ser realizada, especialmente, por meio do tipo de indumento presente nessas espécies.

8. Croton ehrenbergii Schltdl., Linnaea 19: 248. 1847. Tipo: [México], [Hidalgo], 'Prope Mineral del Monte in Cuesta Blanca, altura 13-1400 hex', Ehrenber [236] (holótipo, HAL!).

Figuras 4f-i; $16 \mathrm{~b}$.

Subarbustos 0,3-1,0 m altura, monóicos; caule lepidoto, tricomas pseudo-lepidotos a estrelado-lepidotos, raios laterais parcialmente unidos (30-40\% do comprimento total), raio porrecto presente, creme, sésseis. Folhas levemente discolores, inteiras, cartáceas, elípticas a ovais, ápice agudo, base obtusa a arredondada, margem inteira, lâmina 0,7-2,2 cm comprimento, 0,6-1,1 cm largura, nervação broquidódroma, nervura primária impressa na face adaxial, saliente na abaxial, nervuras secundárias pouco evidentes nas duas faces foliares, face adaxial lepidota, tricomas pseudo-lepidotos a estrelado-lepidotos, raios laterais parcialmente unidos (30-40\% do comprimento total), raio porrecto presente, creme a dourados, sésseis, face abaxial lepidota, tricomas pseudo-lepidotos a estrelado-lepidotos, raios laterais parcialmente unidos (30-40\% do comprimento total), raio porrecto presente, creme a cinéreos, sésseis; pecíolos 3,0-6,0 mm comprimento Inflorescências racemos bissexuados, 6,0-7,0 mm comprimento, lepidotos, tricomas pseudo-lepidotos a estrelado-lepidotos, raios laterais parcialmente unidos (30-40\% do comprimento total), raio porrecto presente, creme a cinéreos, sésseis; brácteas inteiras, persistentes, ca. 1,0 $\mathrm{mm}$ comprimento, triangulares, ápice agudo a acuminado, face abaxial lepidota, tricomas pseudo-lepidotos a estrelado-lepidotos, raios laterais parcialmente unidos (30-40\% do comprimento total), raio porrecto presente, creme, sésseis, face adaxial glabra. Flores estaminadas alvas, creme a amareladas, ca. 2,5 mm comprimento; pedicelos ca. 1,5 mm comprimento; sépalas ca. 2,0 mm comprimento, coriáceas, ovais, ápice agudo, face abaxial lepidota, tricomas lepidoto-típicos, raios laterais parcialmente unidos (ca. 90\% do comprimento total), raio porrecto ausente, creme a dourados, sésseis, face adaxial glabra; pétalas ca. $2,5 \mathrm{~mm}$ comprimento, membranáceas, estreitamente espatuladas, ápice arredondado, metade proximal da margem vilosa, tricomas simples, alvos, faces abaxial e adaxial glabras; estames 12 , filetes ca. 1,5 mm comprimento, levemente subulados, pubescentes, tricomas simples, alvos, anteras ca. 1,0 mm comprimento, conectivos glabros; receptáculo tomentoso, tricomas simples, alvos; disco 5-lobado. Flores pistiladas esverdeadas a amareladas, ca. 2,0 mm comprimento; 1,0-1,5 mm comprimento; sépalas iguais, ca. $1,8 \mathrm{~mm}$ comprimento, coriáceas, triangulares, ápice acuminado, face abaxial lepidota, tricomas pseudo-lepidotos a estrelado-lepidotos, raios laterais parcialmente unidos (30-40\% do comprimento total), raio porrecto presente, creme, sésseis, face adaxial glabra; pétalas ausentes; disco inteiro; ovário lepidoto, tricomas pseudo-lepidotos a estrelado-lepidotos, raios laterais parcialmente unidos (30-40\% do comprimento total), raio porrecto presente, creme, sésseis; estiletes bífidos, ramificados a partir do terço distal, lepidotos, tricomas pseudo-lepidotos a estrelado-lepidotos, raios laterais parcialmente unidos (30-40\% do comprimento total), raio porrecto presente, creme, sésseis; regiões estigmáticas 6, glabras. Frutos ca. 6,0 mm comprimento, ca. 5,0 $\mathrm{mm}$ largura; sementes ca. 4,5 mm comprimento, ca. 3,5 mm largura, elipsóides, testa castanha, levemente rugosa.

Distribuição geográfica e hábitats: Trata-se de uma espécie endêmica do México, onde ocorre nas províncias de Hidalgo (maioria das coleções), Queretaro de Arteaga e Vera Cruz-Llave. Ocorre em 
região de pasto sobre as rochas vulcânicas dos grupos San Cristóbal e San Juan, geralmente, em associação com espécies dos gêneros Agave L. e Yucca L.. Também foi coletada em áreas com vegetação xerófila do tipo carrasco, e em regiões com solo removido, em áreas de reflorestamento. É encontrada em regiões com cotas altitudinais elevadas, acima dos $2.000 \mathrm{~m}$ de altura.

Fenologia: Flores ocorrem de julho a novembro. Frutos foram observados apenas em agosto e setembro.

Material examinado: México: Hidalgo: Ajacuba: colina a nordeste de "La Mesa Chata", cerro a noroeste do povoado de Santiago Tezontlale, Serra do "Mexe", 20 10' 55" N e 99 7' 35" W, elev. 2.460 m, 14 set. 1988 (fl), I.D. Vilchis, F. Gonzáles M. \& A. Hernandez G. 217 (M, MEXU); noroeste do povoado de Santiago Tezontlale, vertente sul da Serra do Mexe, elev. 2.460 m, 14 set. 1988 (fl, fr), I.D. Vilchis, F. González M. \& A. Hernández G. 226 (MBM, MEXU, NY); "La barranca", ao norte do povoado de Emiliano Zapata, vertente sul da Serra de Chicavasco, $20^{\circ}$ 9' 30" N e 99 1'30" W, elev. 2.180 m, 26 out. 1989 (fl), I.D. Vilchis, A. Díaz V. \& A. Díaz V. 597 (MEXU). Pachuca: 7 ago. 1948 (fl), F. Miranda 4450 (MEXU). San Augustin Tlaxiaca: $2 \mathrm{~km}$ ao norte de Huixmi, elev. $2.500 \mathrm{~m}, 31$ ago. 1980 (fl), $J$. Rzedowski 36942 (MO). Tulancingo: $4 \mathrm{~km}$ a leste de Tulancingo, elev. 2.400 m, 4 jul. 1979 (fl), R. Hernández M. 3308 (MEXU); Tracción, El Abra, ca. $2 \mathrm{~km}$ a nordeste de Tulancingo, 9 set. 1981 (fl), A. Mancera O. 156 (MEXU). Queretaro de Arteaga: Landa de Matamoros: Cerro Grande, 6-7 km a nordeste de Lagunita de San Diego, elev. 2.5002.600 m, 27 out. 1990 (fl), H. Rubio 2042 (MEXU); El Puerto de La Cíenega, ca. 3,5 km a nordeste de La Lagunita de San Diego, elev. 2.100 m, 21 set. 1999 (fl), E. Pérez \& E. Caranza 3945 (MEXU). Pinal de Amoles: a sudoeste de 4 Palos, elev. 2.370 m, 28 nov. 1990 (fl), E. Carranza 2973 (MEXU). Veracruz-Llave: Acultizingo: caminho para a ponte Colorado, limite entre Veracruz e Puebla, $18^{\circ}$ 42' N e $21^{\circ} \mathrm{W}$, elev. 2.350 m, 6 nov. 1985 (fl), J.L. Martinez \& $R$. Acosta 1014 (NY).

Croton ehrenbergii, espécie mexicana, é muito semelhante, morfologicamente, a $C$. hypoleucus Schltdl., outra espécie endêmica do México, ocorrendo nos mesmos tipos de hábitats. A distinção entre esses dois táxons pode ser feita por meio do tipo de indumento da face adaxial das folhas, pois enquanto em $C$. ehrenbergii a face adaxial das folhas é coberta por tricomas que variam de pseudo-lepidotos a estrelado-lepidotos, com raios laterais unidos em 30 a $40 \%$ da sua extensão total, em C. hypoleucus os tricomas dessa região são estrelados, com raios laterais totalmente livres. Além disso, em C. hypoleucus, os tricomas da face adaxial das folhas são caducos e caem à medida que as folhas se desenvolvem deste modo, é possível observar, em um mesmo indivíduo, desde folhas com a face adaxial indumentada até aquelas completamente glabras.

Croton ehrenbergii e C. hypoleucus são os dois únicos representantes da seção Lamprocroton que ocorrem fora da América do Sul e, apesar dessa ser uma distribuição geográfica incomum, os caracteres morfológicos que exibem forte evidência de que essas espécies sejam classificadas na supracitada seção. Foram observados materiais de outras espécies de Croton que ocorrem no México e que possuem folhas pequenas e com indumento lepidoto, como C. dioicus Müll. Arg. e C. neomexicanus Müll. Arg., porém nessas espécies os estiletes são multífidos e assim elas não foram incluídas na seção Lamprocroton (Webster 1993). Assim, decidiu-se incluir C. ehrenbergii no tratamento taxonômico de $C$. sect. Lamprocroton, por conta dos caracteres morfológicos, aceitando-se a proposição de Webster (1993), segundo quem ela seria um representante típico da citada seção.

9. Croton ericoides Baill., Adansonia 4: 293. 1864. Tipo: [Brasil], 'Prov. de RioGrande-do-Sul', [1816-1821], Saint-Hilaire C2-1812 (holótipo, P!).

Figuras 5a-g; 16c.
Arbustos, 0,3-1,0 m altura, monóicos; caule lepidoto, tricomas lepidoto-típicos, raios laterais parcialmente unidos (ca. 95\% do comprimento total), raio porrecto ausente, dourados a acastanhados, sésseis. Folhas levemente discolores, inteiras, subcoriáceas, lanceoladas, estreitamente oblongas a estreitamente elípticas, ápice agudo, acuminado, arredondado a apiculado, base aguda, margem inteira, lâmina 0,5-1,3 cm comprimento, 0,5-1,5 mm largura, nervação hifódroma, impressa na face adaxial, saliente na abaxial, face adaxial lepidota, tricomas lepidoto-típicos, raios laterais parcialmente unidos (ca. 95\% do comprimento total), raio porrecto ausente, creme a dourados, sésseis, face abaxial lepidota, tricomas lepidototípicos, raios laterais parcialmente unidos (ca. 95\% do comprimento total), raio porrecto ausente, creme a dourados, sésseis; pecíolos 0,8-1,5 mm comprimento Inflorescências racemos unissexuados, 0,5-1,7 cm comprimento, lepidotos, tricomas lepidoto-típicos, raios laterais parcialmente unidos (ca. $90 \%$ do comprimento total), raio porrecto ausente, dourados a acastanhados, sésseis; brácteas inteiras, persistentes, 0,5-2,0 mm comprimento, estreitamente triangulares, ápice agudo, face abaxial lepidota, tricomas lepidoto-típicos, raios laterais parcialmente unidos (ca. 95\% do comprimento total), raio porrecto ausente, creme a dourados, sésseis, face adaxial glabra. Flores estaminadas alvas a creme, 1,3-2,5 mm comprimento; pedicelos 1,0-2,0 mm comprimento; sépalas 1,8-2,0 mm comprimento, coriáceas, ovais, ápice agudo, face abaxial lepidota, tricomas lepidototípicos, raios laterais parcialmente unidos (ca. 95\% do comprimento total), raio porrecto ausente, creme a dourados, sésseis, face adaxial glabra; pétalas ca. 1,5 mm comprimento, membranáceas, oblanceoladas, ápice arredondado, ápice e metade distal da margem ciliados, tricomas simples, alvos, metade proximal da margem vilosa, tricomas simples, alvos, face abaxial lepidota, tricomas estrelado-lepidotos, raios laterais parcialmente unidos (ca. 50\% do comprimento total), raio porrecto ausente, alvos a creme, sésseis, face adaxial glabra; estames 10-13, filetes ca. 1,5 mm comprimento, levemente subulados, glabros, anteras 0,5-1,0 mm comprimento, conectivos glabros; receptáculo tomentoso, tricomas simples, alvos; disco 5-lobado. Flores pistiladas alvas a creme, 1,8-3,0 mm comprimento; pedicelos 1,5-2,0 mm comprimento; sépalas desiguais, duas menores, 1,5-2,5 mm comprimento, três maiores, 2,0-3,0 mm comprimento, coriáceas, estreitamente-triangulares, ápice agudo, face abaxial lepidota, tricomas lepidoto-típicos, raios laterais parcialmente unidos (ca. 95\% do comprimento total), raio porrecto ausente, creme a dourados, sésseis, metade distal da face adaxial tomentosa, tricomas estrelados, raio porrecto presente, alvos, sésseis; pétalas presentes, reduzidas; disco 5-lobado; ovário lepidoto, tricomas lepidoto-típicos, raios laterais parcialmente unidos (ca. 95\% do comprimento total), raio porrecto ausente, creme a dourados, sésseis; estiletes bífidos, ramificados desde a base, glabros; regiões estigmáticas 6 , glabras. Frutos 4,0-5,0 mm comprimento, 4,0-4,5 mm largura; sementes ca. 3,0 mm comprimento, ca. 2,0 mm largura, ovóides a elipsóides, testa castanho-alaranjada, lisa a levemente rugosa.

Distribuição geográfica e hábitats: Croton ericoides ocorre, exclusivamente, no estado do Rio Grande do Sul, onde foi coletada nos municípios de Capão da Canoa, Osório, Palmares do Sul, Torres e Tramandaí. Allem (1978), no seu trabalho sobre o gênero Croton no Rio Grande do Sul, faz inferências sobre o possível endemismo de C. ericoides para o citado estado, dizendo que a espécie ocorre exclusivamente no litoral do Rio Grande do Sul, em dunas e nas proximidades de lagoas, em solo arenoso e tais inferências foram aqui corroboradas. Parece ocorrer, preferencialmente, em regiões de capoeira, em campo, em ambientes litorâneos, na margem de lagos e lagoas e próxima a afloramentos rochosos, sempre em solo arenoso, em regiões com cotas altitudinais baixas, geralmente, ao nível do mar. 
Fenologia: Foram observados indivíduos com flores nos meses de janeiro, fevereiro, abril e de setembro a dezembro. Frutos foram encontrados apenas nos meses de fevereiro, outubro e novembro.

Material examinado: Brasil: Rio Grande do Sul: Capão da Canoa: Curumirim, entre Curumirim e Arroio do Sal, fev. 1978 (fl), Pfadenhauer 290 (ICN). Osório: Fazenda do Arroio, 4 jan. 1950 (fl), B. Rambo s.n. (LIL n.v., PACA 45186, W); id., 14 abr. 1950 (fl), B. Rambo s.n. (ICN, PACA 46768); 11 set. 1950 (fl), B. Rambo s.n. (ICN, MO, NY, PACA 48773); 11 set. 1950 (fl), B. Rambo s.n. (B, G, ICN, PACA 48799, W); Fazenda do Arroio para Osório, 3 out. 1954 (fl), B. Rambo s.n. (PACA 55886); Fazenda do Arroio, 3 out. 1954 (fl, fr), B. Rambo s.n. (B, PACA 55887); id., set. 1957 (fl), B. Rambo s.n. (PACA 61458); id., set. 1957 (fl), B. Rambo s.n. (B, PACA 61459); Lagoa dos Barros, $10 \mathrm{~km}$ a sudoeste de Osório, 12 nov. 1972 (fl, fr), J.C. Lindeman et al. s.n. (ICN 20802); na estrada à direita do acesso à Tramandaí, na Free Way, 30 jan. 1974 (fl), A. Allem et al. s.n. (ICN 25278). Palmares do Sul: Balneário de Dunas Altas, Lagoa da Porteira, próximo à fazenda Duas Lagoas, 27 nov. 2003 (fl, fr), L.R. Lima 321 (SPF). Torres: ca. de $12 \mathrm{~km}$ a sudoeste de Torres, s.d. (fl), J.C.L. et al. s.n. (ICN 9267); 11 fev. 1954 (fl), B. Rambo s.n. (B, PACA 54764); 11 fev. 1954 (fl, fr), B. Rambo s.n. (B, PACA 54824). Tramandaí: Tramandaí para Osório, 13 fev. 1933 (fl), B. Rambo 110 (PACA); Parque Osório, 8 nov. 1975 (fl), B. Irgang s.n. (ICN 29761); Lagoa do Manoel Nunes, 9 dez. 1981 (fl), M. Sobral \& P. Brack 802 (MBM).

Croton ericoides talvez seja uma das espécies de Croton mais fáceis de serem reconhecidas e isso é possível mesmo quando em estado vegetativo. As folhas são muito pequenas, com no máximo $1,3 \mathrm{~cm}$ de comprimento, e estreitas, com largura variando de 0,5 a $1,5 \mathrm{~mm}$. O tamanho das folhas é ressaltado pelo próprio autor da espécie, já que no protólogo Baillon (1864) cita, como limites máximos de comprimento e largura das folhas de $C$. ericoides, $2,0 \mathrm{~cm}$ e 1,0 a 2,0 mm, respectivamente. Há outra espécie da seção Lamprocroton que também ocorre no Rio Grande do Sul e possui folhas relativamente pequenas. Trata-se de um novo táxon denominado C. pygmaeus L.R. Lima, muito semelhante a C. ericoides que pode, a princípio, ser confundido com esta espécie, entretanto enquanto em $C$. ericoides os tricomas das duas faces foliares são tipicamente lepidotos, com raios laterais unidos em aproximadamente $95 \%$ do seu comprimento total, em C. pygmaeus a face adaxial das folhas é coberta por indumento tomentoso, formado por tricomas estrelados, com raios laterais completamente livres. Além disso, enquanto C. ericoides ocorre em regiões de restinga, com solo arenoso e com cotas altitudinais baixas, C. pygmaeus foi coletada apenas em regiões elevadas, próximas a afloramentos rochosos. Croton tenellus, uma espécie endêmica de Minas Gerais, também possui folhas pequenas, porém, nesse táxon, as folhas são elípticas enquanto em $C$. ericoides e $C$. pygmaeus elas variam de lanceoladas a estreitamente elípticas.

Croton ericoides foi descrita por Baillon (1864), com base em um material proveniente do Rio Grande do Sul e apesar de alguns caracteres observados aqui não coincidirem com a diagnose, como, por exemplo, o número de estames - 15 na descrição original e, no máximo, 13 nos materiais aqui estudados - a análise do holótipo e a coincidência de outras características presentes na diagnose tais como tamanho e largura das folhas, tamanho dos pecíolos e local de ocorrência da espécie (Rio Grande do Sul), não deixam dúvidas sobre a identidade da mesma. No Prodromus, Mueller (1866) comentou a proximidade de $C$. ericoides e $C$. myrianthus, mas as manteve como entidades distintas por conta da presença de "flores monoici" na primeira e "flores dioici", na segunda. Acredita-se aqui que o que Mueller (1866) chama de "flores monoici" possa significar planta monóica, ou seja, mesmo que o tipo de inflorescência apresentado pela espécie seja o unissexuado, em um mesmo indivíduo podem existir tanto inflorescências masculinas como femininas. Em contrapartida, o chamado por Mueller (1866) "flores dioici" deve significar planta dióica, caso de $C$. myrianthus.

10. Croton erythroxyloides Baill., Adansonia 4: 297. 1864. Tipo: [Brasil], 'Prov. de Minas-Geräes', [1816-1821], Saint-Hilaire B2-2245 pr. p. (holótipo, P!).

Croton erythroxyloides var. buxifolius Baill., Adansonia 4: 297. 1864. Croton buxifolius (Baill.) Müll. Arg. in De Candolle, Prodr. 15 (2): 676. 1866. Tipo: [Brasil], 'Prov. de Minas Geraës', [1816-1821], Saint-Hilaire [B2]2245 pr. p. (holótipo, P!).

Croton erythroxyloides var. cneorifolius Baill., Adansonia 4: 297. 1864. Croton cneorifolius var. genuinus Müll. Arg. in De Candolle, Prodr. 15 (2): 677. 1866. nom. inval. Tipo: [Brasil], 'Prov. de Minas-Geräes', 1844, Weddell, ex don. Claussen s.n. (holótipo, P!). syn. nov.

Croton erythroxyloides var. longifolius Baill., Adansonia 4: 298. 1864. Croton cneorifolius var. longifolius Müll. Arg. in De Candolle, Prodr. 15 (2): 676. 1866. Tipo: [Brasil], 'Prov. de Minas Geräes', [1816-1821], Saint-Hilaire B1-78[0] (holótipo, P!). syn. nov.

Croton erythroxyloides var. lanceolatus Baill., Adansonia 4: 298. 1864. Croton cneorifolius var. lanceolatus (Baill.) Müll. Arg., in De Candolle, Prodr. 15 (2): 677. 1866. Tipo: [Brasil], 'Prov. de Minas-Geräes, Carassa', 1843, Claussen 330 (lectótipo, P!; isolectótipo, P!). syn. nov.

Croton oleoides Müll. Arg., Linnaea 34: 82. 1865. Tipo: 'In Brasilia prov. Minas Geräes', Pohl 1616 (lectótipo, W!; isolectótipo, K!). Remanescentes dos síntipos originais: 'In Brasiliae prov. Minas Geraës', s.d., Casaretto 2508 (G!). 'In Brasilia prov. Minas Geräes', s.d., Lund s.n. (B †). 'In Brasiliae prov. Minas Geraës', [1834], Riedel s.n. (G!, P!, W!). syn. nov.

Croton riedelianus Müll. Arg., Linnaea 34: 104. 1865. Tipo: 'In Brasiliae prov. Minas Geraës', [1834], Riedel s.n. (holótipo, B†; lectótipo, G!; isolectótipos, P!, W! fotografias do holótipo, G!, K!, NY!). Remanescentes dos síntipos originais: 'In Brasilia prov. Minas Geraës', s.d., Sellow s.n. (B†). 'In Brasilia prov. Minas Geraës', s.d., Lund s.n. (G!).

Croton widgrenianus Müll. Arg., Linnaea 34: 104. 1865. Tipo: 'In Brasiliae prov. Minas Geraës', [1845], Widgren [315] (holótipo, UPS!; isótipos, G!, W!). syn. nov.

Croton squamulosus Müll. Arg. in Mart. \& Eichl., Fl. bras. 11 (2): 244.1873. nom. illeg. [non Vahl] = Croton macrolepsis Radcl.-Sm. \& Govaerts. Tipo: [Brasil], 'Habitat prope Rio de Janeiro', [grand plateau des Orgues], [8 out. 1969], Glaziou 3742 (holótipo, BR!; isótipos, F 538453!, K!). syn. nov.

Figuras 5h-s; 16d.

Subarbustos a arbustos, 0,4-2,0 m altura, monóicos; caule lepidoto, tricomas lepidoto-típicos, raios laterais parcialmente unidos (ca. 95\% do comprimento total), raio porrecto ausente, acastanhados a dourados, sésseis. Folhas discolores, inteiras, cartáceas, elípticas, ovais a, raramente, obovais, ápice agudo a arredondado, mucronulado, base aguda, arredondada a, raramente, assimétrica, margem inteira, lâmina 1,2-5,2 cm comprimento, 0,4-2,2 cm largura, nervação broquidódroma, nervura primária impressa na face adaxial, saliente na abaxial, nervuras secundárias pouco evidentes nas duas faces foliares, face adaxial, lepidota, tricomas lepidoto-típicos, raios laterais parcialmente unidos (ca. 95\% do comprimento total), raio porrecto presente, cinéreos, creme, dourados a esverdeados, sésseis, face abaxial lepidota, tricomas lepidoto-típicos, raios laterais parcialmente unidos (ca. 95\% do comprimento total), raio porrecto presente, cinéreos, creme, dourados a esverdeados, sésseis; pecíolos 1,0-10,0 mm comprimento Inflorescências racemos bissexuados, 1,0-3,5 cm comprimento, lepidotos, tricomas lepidoto-típicos, raios laterais parcialmente unidos (ca. $90 \%$ do comprimento total), raio porrecto ausente, creme a dourados, sésseis; brácteas inteiras, persistentes, 1,0-4,0 mm comprimento, estreitamente triangulares, ápice agudo a acuminado, face abaxial lepidota, tricomas lepidoto-típicos, raios laterais parcialmente unidos (ca. $90 \%$ do comprimento total), raio porrecto ausente, creme a dourados, sésseis, metade distal da 
face adaxial tomentosa, tricomas estrelados, raio porrecto ausente, alvos a creme, sésseis. Flores estaminadas alvas, creme, amarelas a creme-esverdeadas, 1,5-4,0 mm comprimento; pedicelos 1,0-3,0 $\mathrm{mm}$ comprimento; sépalas 1,5-3,0 mm comprimento, coriáceas, ovais, ápice agudo a acuminado, face adaxial lepidota, tricomas lepidototípicos, raios laterais parcialmente unidos (ca. 95\% do comprimento total), raio porrecto ausente, creme a dourados, sésseis, face adaxial glabra; pétalas 2,0-3,5 mm comprimento, membranáceas, estreitamente elípticas, ápice arredondado, ápice e metade distal da margem ciliados, tricomas simples, alvos, metade proximal da margem vilosa, tricomas simples, alvos, face abaxial lepidota, tricomas lepidototípicos, raios laterais parcialmente unidos (ca. 90\% do comprimento total), raio porrecto ausente, creme, sésseis, região proximal da face adaxial vilosa, tricomas simples, alvos; estames (9-)10-12(-15), filetes 1,5-3,0 mm comprimento, filiformes, pubescentes, tricomas simples, alvos, anteras $0,5-1,0 \mathrm{~mm}$ comprimento, conectivos glabros; receptáculo tomentoso, tricomas simples, alvos; disco 5-lobado. Flores pistiladas creme, paleáceas, esverdeadas, ocráceas, acastanhadas a creme-esverdeadas, 3,0-6,0 $\mathrm{mm}$ comprimento; pedicelos 1,0-2,0 mm comprimento; sépalas desiguais, duas menores, 3,0-3,5 mm comprimento, três maiores, 4,0-5,0 mm comprimento, coriáceas, espatuladas a ovais, ápice agudo a arredondado, face abaxial lepidota, tricomas lepidoto-típicos, raios laterais parcialmente unidos (ca. 95\% do comprimento total), raio porrecto ausente, creme a dourados, sésseis, metade distal da face adaxial lepidota, tricomas lepidoto-típicos, raios laterais parcialmente unidos (ca. $80 \%$ do comprimento total), raio porrecto presente, alvos a creme, sésseis; pétalas presentes, reduzidas; disco inteiro; ovário lepidoto, tricomas lepidoto-típicos, raios laterais parcialmente unidos (ca. 90\% do comprimento total), raio porrecto ausente, creme a dourados, sésseis; estiletes bífidos, ramificados desde a base, lepidotos, especialmente na região proximal, tricomas lepidoto-típicos, raios laterais parcialmente unidos (ca. 90\% do comprimento total), raio porrecto ausente, alvos, creme a dourados, sésseis; regiões estigmáticas 6 , glabras a, raramente, lepidotas, tricomas lepidoto-típicos, raios laterais parcialmente unidos (ca. $90 \%$ do comprimento total), raio porrecto ausente, creme a dourados, sésseis. Frutos 4,0-8,0 mm comprimento, ca. 4,0 mm largura; sementes 3,5-4,0 mm comprimento, ca. 2,5 mm largura, elipsóides, testa castanho-clara a atro-acastanhada, lisa.

Distribuição geográfica e hábitats: Croton erythroxyloides é encontrada, freqüentemente, em campos de altitude, campo sujo e campo rupestre, sempre associada a afloramentos rochosos, em regiões com altitudes superiores aos $1.000 \mathrm{~m}$. Isso sem dúvida explica a sua documentação geográfica fragmentada e pontual, como descrita a seguir. A grande maioria das coleções examinadas de C. erythroxyloides é proveniente da Serra da Piedade, localizada no município de Caeté, no estado de Minas Gerais. Vale ressaltar que muitas das coleções citadas por Mueller (1866), no protólogo de C. buxifolius, um dos sinônimos de C. erythroxyloides, são dessa região como, por exemplo, Riedel 2805 e Lund 34. Pode também ser encontrada em outras localidades do estado de Minas Gerais como na Serra da Bandeirinha, localizada no Parque Nacional da Serra do Cipó; no Pico do Inficionado, localizado na Serra do Caraça; no Parque Nacional do Caparaó; no Pico do Itabirito, região localizada na Serra dos Inconfidentes e na Pedra Branca, no município de Caldas. O holótipo de C. erythroxyloides var. lanceolata (Claussen 330) foi coletado na Serra do Caraça, entretanto, além dessa existem algumas outras poucas coleções provenientes dessa região, o que leva a crer que $C$. erythroxyloides é, atualmente, uma espécie rara nessa localidade visto que, nessa área, há um esforço de coleta grande. Há também registros de C. erythroxyloides no estado do Rio de Janeiro, onde foi coletada no Parque Estadual do Desengano, em Santa Maria Madalena; no Morro da Bandeira, no município de Petrópolis e, em
Teresópolis, próximo à Pedra do Sino, no Parque Estadual da Serra dos Órgãos. No estado de São Paulo, foi coletada apenas na região de São Bento do Sapucaí, na Pedra do Bauzinho e, em Santa Catarina, somente na Serra Geral e na Serra do Rio do Rastro.

Fenologia: Flores foram observadas o ano inteiro. Frutos foram observados de janeiro a março e em julho, agosto e outubro.

Material examinado: Brasil: s.d. (fl), s.c. (RB 10303); s.d. (fl), s.c. (G 5335); s.d. (fl), Riedel s.n. (P); s.d. (fl), Riedel s.n. (NY s.n.); s.d. (fl), Riedel s.n. (NY 00503996); s.d. (fl), Riedel s.n. (NY 00503997); s.d. (fl), Sellow 2113 (NY, SP); s.d. (fl), M. Warming 1707 (G); s.d. (fl), Riedel 374 (W); s.d. (fl), Sellow 2074 (SP); mar. 1841 (bt), Gardner 5833 (K); 1843 (fl), M. Claussen 398 (G). Minas Gerais: s.d. (fl), Gardner 5773 (W); s.d. (fl), P. Claussen 184 (W); ago-abr. 1840 (fl), P. Claussen s.n. (K). Barão de Cocais: Serra do Garimpo, 13 jan. 1921 (fl), F.C. Hoehne 4947 (SP); Mina de Brucutu, CVRD, 9 fev. 1999 (fl), M.R.S.M. Marques-Leitão et al. s.n. (BHCB 45744); id., 9 fev. 1999 (fl), M.R.S.M. Marques-Leitão et al. s.n. (BHCB 45760); id., Picha do Cavalo, $19^{\circ} 53$ ' 8" S e 43 26' 10,9" W, 31 jan. 2002 (fl), A.M. Oliveira \& J.R. Stehmann 19 (BHCB, SPF). Caeté: Serra da Piedade, s.d. (fl), M. Warming s.n. (G 41); id., 10 out. 1880 (fl), M. Warming s.n. (P); id., 1893 (fl), C. Thomas 1075 (OUPR); id., nov. 1893 (fl), Schwacke 2778 (RB); id., 28 jul. 1933 (fl), M. Barreto 2701 (BHCB); id., 6 maio 1934 (fl), M. Barreto 8119 (F); id., elev. 1800 m, 29 mar. 1957 (fl, fr), E. Pereira 2668 \& Pabst 3504 (RB); id., 35 km a leste de Belo Horizonte, próximo à BR 31, elev. 1.800-2.000 m, 13 jan. 1971 (fl, fr), H.S. Irwin, R.M. Harley \& E. Onishi 30234 (K, MO, NY, RB); id, ca. de $35 \mathrm{~km}$ a leste de Belo Horizonte, próximo à BR 31, elev. ca. 2.000 m, 18 jan. 1971 (fl), H.S. Irwin, R.M. Harley \& E. Onishi 30646 (F, K, MO, NY, RB); id., 20 out. 1973 (fl), C. Koczicki 294 (MBM); id., km 1-5 na estrada do topo da serra, $19^{\circ} 55^{\prime} \mathrm{S}$ e $43^{\circ} 45^{\prime} \mathrm{W}$, elev. 1.200-1.700 m, 2 fev. 1982 (fl, fr), L.R. Landrum 4259 (MBM, MO, NY); id., elev. 1.620 m, 28 abr. 1985 (fl), M.N. Elcione, G.S. Jussara \& T.S.M. Grandi 1742 (BHCB); id., 19 49' S e 43 40' W, elev. 1.720 m, 29 jun. 1985 (fl), J. Siqueira, J. Paula \& T.S.M. Grandi 1858 (BHCB); id., $19^{\circ} 49^{\prime}$ S e $43^{\circ} 40^{\prime}$ W, elev. 1.650 m, 4 nov. 1985 (fl), J. Paula et al. 2144 (BHCB); id., 28 ago 1986 (fl), J.L. Silva s.n. (OUPR 2343); id., alto da serra, $20^{\circ} 40^{\prime} \mathrm{S}$ e $43^{\circ} 40^{\prime} \mathrm{W}$, elev. ca. $1.600 \mathrm{~m}, 20$ jul. 1987 (fl), D.C. Zappi, J.R. Pirani \& R. Mello-Silva CFCR 11154 (SPF); Serra da Moeda, 19 out. 1987 (fl), M.M.N. Braga et al. s.n. (BHCB 13771); id, 19 out. 1987 (fl), M.M.N. Braga et al. s.n. (BHCB 13375); id., 27 out. 1987 (fl), M.M.N. Braga 155 (BHCB); Morro da Piedade, Serra da Moeda, 26 out. 1988 (fl), S.B. Velten 3 (BHCB); id., 26 out. 1988 (fl, fr), S.B. Velten 4 (BHCB, MBM); Serra da Piedade, $19^{\circ} 54^{\prime} \mathrm{S}$ e $43^{\circ} 38^{\prime} \mathrm{W}$, elev. 1.480-1.650 m, 14 maio 1990 (fl), M.M. Arbo et al. 4101 (SP, SPF); Serra da Piedade, $19^{\circ} 49^{\prime} 7,6^{\prime \prime} \mathrm{S}$ e $43^{\circ} 40^{\prime} 44,1^{\prime \prime} \mathrm{W}$, elev. $1.480 \mathrm{~m}, 11$ jan. 1996 (fl), V.C. Souza et al. 10062 (CESJ n.v., CTES,

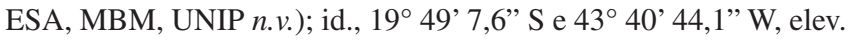
$1.480 \mathrm{~m}, 11$ jan. 1996 (f), V.C. Souza et al. 10069 (CESJ n.v., ESA, UNIP n.v.); id., $19^{\circ} 49^{\prime} 7,6^{\prime \prime} \mathrm{S}$ e $43^{\circ} 40^{\prime} 44,1^{\prime}$ ' W, elev. $1.480 \mathrm{~m}$, 11 jan. 1996 (fl), V.C. Souza et al. 10073 (ESA, SPF); id., $19^{\circ} 49^{\prime} 25,5^{\prime}$ ' $\mathrm{S}$ e 43 40' 18,7' W, elev. $1.640 \mathrm{~m}, 11$ jan. 1996 (fl), V.C. Souza et al. 10101 (CESJ n.v., ESA); id., 19 49' 25,5” S e 43 40' 18,7' W, elev. 1.640 m, 11 jan. 1996 (fl), V.C. Souza et al. 10106 (BHCB, ESA, SPF); id., 19² 49' S e 43 40’ W, 15 ago. 1998 (fl), R.C. Forzza et al. 964 (SP, SPF). Caldas: s.d. (fl), A.F. Regnell s.n. (G ); 18-23 out. 1845 (fl, fr), A.F. Regnell 1082 (F, K, M, P, WU); 1874 (fl), Mosén 2000 (P); Pedra Branca, 21 jan. 1919 (fl), F.C. Hoehne 2837 (NY, SP); id., elev. 2000 m, 24 jan. 1980 (fl, fr), A. Krapovickas \& C.L. Cristóbal 35484 (CTES, F); Pocinhos do Rio Verde, Pedra Branca, 15 maio 2005 (fl, fr), L.R. Lima 379 (SP, SPF, WIS). Camanducaia: Serraria Esperança, 19 dez. 1951 (fl), P. Gonçalves \& M. Kuhlmann 3192 (SP); ca. de $15 \mathrm{~km}$ da fazenda 
Boa Vista, na estrada para Camanducaia, 14 out. 1968 (fl), J. Mattos 15413 (SP). Caparaó: Serra do Caparaó, elev. 2.700 m 8 set. 1941 (fl), A.C. Brade 16978 (RB); a 4 km do Pico da Bandeira, elev. 2.500 m, 6 ago. 1969 (fl), A.B. Souza \& Márcia 4 (RB); Parque Nacional do Caparaó, elev. 2.500 m, 2 jan. 1993 (fl), L.S. Leoni 2044 (SP). Itabira: Serra de Itabira do Campo, s.d. (fl), L. Damazio s.n. (RB 82952); id., s.d. (fl), L. Damazio s.n. (OUPR 6114); Cauê, 12 fev. 1934 (fl), A. Sampaio 7076 (BHCB). Itabirito: Pico do Itabirito, ca. $50 \mathrm{~km}$ a sudeste de Belo Horizonte, elev. 1750 m, 11 fev. 1968 (fl, fr), H.S. Irwin, H. Maxwell \& D.C. Wasshausen 19822 (B, F, G, K, M, MO, NY, P, SP); 19 dez. 1970 (fl), L. Krieger 9733 (RB); 19 dez. 1970 (fl), P.I.S. Braga et al. 2040 (RB); Serra dos Inconfidentes, Pico do Itabirito, 31 maio 1994 (fl, fr), W.A. Teixeira s.n. (BHCB 25086). Mariana: Gandarela, elev. 1570 m, 13 jul. 1972 (fl), L. Emygdio et al. 3249 (R n.v., NY); elev. 1300 m, 14 jul. 1972 (fl), L. Emygdio et al. 3341 (R n.v., NY); área da Samarco, 15 ago. 2000 (fl, fr), A.E. Brina s.n. (BHCB 60048); id., 10 dez. 2000 (fl), A.E. Brina s.n. (BHCB 60074). Nova Lima: Capão Xavier, $20^{\circ} 2$ ' $55^{\prime \prime}$ S e $43^{\circ} 58^{\prime} 43^{\prime \prime} \mathrm{W}$, elev. 1.474 m, 13 mar. 2001 (fl), M. Pimentel et al. 64 (BHCB). Ouro Preto: próximo à cidade, s.d. (fl), Martius 1128 (M); Lavras Novas, Serra de Lavras Novas, ca. $20 \mathrm{~km}$ ao sul de Ouro Preto, 26 ago. 1960 (fl), B. Maguire, G.M. Magalhães \& C.K. Maguire 49307 (MO, NY); Alegria Sul, Samarco, Mineração Antônio Pereira, 23 jul. 1996 (fl), M.B. Roshel \& J. Craig 229 (OUPR); id., estrada da torre, 10 jan. 1997 (fl, fr), M.B. Roshel 547 (OUPR). Sapucaí Mirim: Serraria Boa Vista, 26 out. 1950 (fl, fr), M. Kuhlmann 2591 (SP); id., 26 out. 1950 (fl), M. Kuhlmann 2592 (NY, SP). Santa Bárbara: s.d. (fl), Pohl 3468 (F, W); Pico do Inficcionado, 1839 (fl), Lund s.n. (P); 1841 (fl), Gardner 5173 (K); Serra do Caraça, perto do Inficcionado, nov. 1898 (fl), Schwacke 13703 (RB); Serra de Catas Altas, 2 mar. 1943 (fl), M. Magalhães 2824 (IAN); $45 \mathrm{~km}$ ao norte de Mariana, no caminho para Santa Bárbara, $20^{\circ} 4^{\prime}$ S e $43^{\circ} 24^{\prime}$ W, 13 mai. 1990 (fl), M.M. Arbo et al. 4023 (CTES, SP, SPF); Serra do Caraça, Pico do Inficcionado, 20 8' 5" S e 43 27' 5" W, elev. 1.900-2.060 m, 26 maio 1997 (fl), R. Mello-Silva, M.L. Kawasaki \& A. Rapini 1379 (SP, SPF, UEC); id., elev. 2.050 m, 8 jan. 2000 (fl, fr), M.F. Vasconcelos s.n. (BHCB 52574). Santana do Riacho: Parque Nacional da Serra do Cipó, Serra da Bandeirinha, elev. ca. 1200 m, 7 set. 1987 (fl), I. Cordeiro et al. CFSC 10476 (SP, SPF); id., 9 set. 1987 (fl), I. Cordeiro et al. CFSC 10499 (SP, SPF); id., próximo à casa do IBDF, elev. ca. 1200 m, 9 set. 1987 (fl), I. Cordeiro et al. CFSC 10500 (F n.v., SP, SPF). Viçosa: alto da Serra do Gramma, 22 mar. 1941 (fl), M. Carmo s.n. (BHCB 36017); id., 22 mar. 1941 (fl), M. Carmo s.n. (BHCB 36018, MBM 258702); id., 22 mar. 1941 (fl), M. Carmo s.n. (BHCB 63264). Rio de Janeiro: 15 jun. 1875 (fl), M.A. Glaziou 3743 (P). Petrópolis: Serra dos Órgãos, 10 set. 1866 (fl), M.A. Glaziou 16334 (G, K, P); Campo da Serra do Palmital, 25 fev. 1884 (fl), M.A. Glaziou 15401 (P); Serra dos Órgãos, elev. 2000 m, 15 jul. 1975 (fl, fr), A.M. Cameril 242 (K); Correias, picada para Açu, próximo ao Morro da Bandeira, elev. 2.000-2.100 m, 31 ago. 1985 (fl), C. Farrey, E.C. Dalcin \& M. Pena 808 (RB, SPF). Santa Maria Madalena: alto do Desengano, elev. 2.000 m, 3 mar. 1934 (fl), J.S. Lima \& Brade 13255 (RB); id., out. 1934 (fl), J.S. Lima 275 (B, RB); Pedra do Abreuzinho, mai. 1936 (fl), J.S. Lima 351 (RB); Parque Estadual do Desengano, Pedra do Desengano, elev. 1.500-1.650 m, 17 set. 1986 (fl), C. Farney \& J.M. Caruso 1198 (K n.v., R n.v., RB); id, Pedra do Desengano, elev. 1.840 m, 4 out. 1988 (fl, fr), G. Martinelli et al. 13117 (F, K., R n.v., RB); id., elev. ca. 1.700 m, 24 mar. 2002 (fl), C.G. Gomes et al. 152 (SPF). Teresópolis: Parque Nacional da Serra dos Órgãos, ca. de $7 \mathrm{~km}$ a sudoeste de Teresópolis, na base da Pedra do Sino, $22^{\circ} 27-28^{\prime}$ 'S e $43^{\circ} 2-3^{\prime}$ W, elev. $2.100 \mathrm{~m}$, 22 abr. 1966 (fl), G. Eiten \& L.T. Eiten 7145 (K, NY, SP); Campo das Antas, 20 abr. 1949 (fl), A. Barb. 117 (RB); id., 21 nov. 1952 (fl),
Rizzini 1149 (RB); id., no caminho para a Pedra do Sino, 13 abr. 2001 (fl), P. Fiaschi, A.Q. Lobão \& S. Vieira 760 (SPF). São Paulo: Cunha: estrada em direção à Pedra da Macela, ca. de $15 \mathrm{~km}$ de Cunha, elev. ca. 1.800 m, 22 mar. 1996 (fl), C.B. Costa, M. Kirizawa \& A. Rapini 176 (SP). São Bento do Sapucaí: Pedra do Bauzinho, $22^{\circ} 41^{\prime} 24$ ' S e 45 39' 27' W, 13 abr. 1995 (fl), J.Y. Tamashiro et al. 857 (ESA, HRCB, SP, SPF, UEC); trilha para a Pedra do Bauzinho, 23 fev. 2003 (fl, fr), L.R. Lima \& A.F. Pontes 287 (SPF); Pedra do Bauzinho, 25 out. 2004 (fl), M.B.R. Caruzo, I. Cordeiro \& S.E. Martins 74 (SP, SPF, WIS). Santa Catarina: Serra Geral, fev. 1890 (fl), E. Ule 1560 (P). Lauro Müller: $15 \mathrm{~km}$ a leste de Bom Jardim da Serra, Serra do Rio do Rastro, elev. 1.400 m, 27 jan. 1982 (fl, fr), A. Krapovickas \& C.L. Cristóbal 37786 (CTES n.v., G); margem da rodovia Bom Jardim da Serra, 10 mar. 1995 (fl), G.F. Arbocz 1225 (SP, WIS).

Croton erythroxyloides é uma das espécies mais polimórficas da seção Lamprocroton e por conta disso desde o momento da sua descrição sempre foi subdividida em variedades, primeiro por Baillon (1864) e em seguida por Mueller (1866). Entretanto, alguns caracteres são sempre constantes e podem ser utilizados como distintivos para o reconhecimento do táxon, entre eles a presença de indumento lepidoto nas duas faces foliares, constituído por tricomas tipicamente lepidotos. A coloração das folhas, verde-acastanhadas na face adaxial e variando de verde-cinéreas a argênteas na face abaxial, é outro caráter que pode auxiliar na identificação da espécie. As folhas são bastante variáveis quanto à forma e tamanho, e o caule é sempre muito ramificado. Baillon (1864) citou a presença de indumento escamoso para a face adaxial das sépalas das flores pistiladas o que foi aqui observado. É interessante comentar que os materiais coletados nos estados de São Paulo e Rio de Janeiro possuem flores pistiladas um pouco diferentes daqueles provenientes de Minas Gerais e Santa Catarina. Nesses materiais (SP e RJ), as sépalas das flores pistiladas são, em geral, ovais e os estiletes são sempre glabros enquanto naqueles coletados nos outros estados as sépalas das flores pistiladas são espatuladas e os estiletes indumentados. Todavia, a análise de outros caracteres morfológicos nos levou a tratar todos esses espécimes como um único táxon. De qualquer modo, uma análise populacional seria interessante para tentar elucidar se tais diferenças morfológicas, associadas a diferentes áreas geográficas, poderiam implicar em diferenças taxonômicas consistentes.

Trata-se de uma espécie muito semelhante a $C$. imbricatus L.R. Lima \& Pirani, uma nova espécie da seção Lamprocroton, da qual pode ser diferenciada pelo tipo de tricoma lepidoto presente nas folhas - lepidoto-típicos, com raios laterais parcialmente unidos - e pelas sépalas das flores pistiladas - espatuladas e desiguais. A forma das brácteas e o indumento da face abaxial dessas estruturas também podem ser utilizados na distinção entre esses dois táxons. Outro fator que reforça o reconhecimento desse novo táxon é sua distribuição geográfica restrita ao estado da Bahia, especialmente aos municípios que compõem a Chapada Diamantina, enquanto $C$. erythroxyloides nunca foi coletada na Bahia, ocorrendo nos estados de São Paulo, Rio de Janeiro, Minas Gerais e Santa Catarina, em regiões com altitudes superiores aos $1.000 \mathrm{~m}$.

11. Croton eskuchei Ahumada, Darwiniana 37 (1-2): 172. 1999. Tipo: 'Argentina, Corrientes, Depto. San Cosme, Isla Toledo', 19 out. 1994 (fl. pist., fr.), Eskuche 06515 (holótipo, CTESN n.v.; isótipo, SI n.v.).

Figuras 1 e 4a-g em Darwiniana 37 (1-2): 173. 1999.

Subarbustos a arbustos, 30,0-50,0 cm, dióicos; caule lepidoto, tricomas dentado-lepidotos, raios laterais parcialmente unidos (ca. $80 \%$ do comprimento total), raio porrecto presente, creme, sésseis. Folhas levemente discolores, inteiras, cartáceas, estreitamente elípticas a estreitamente oblongas, ápice agudo a arredondado, base aguda 
a arredondada, margem inteira, lâmina 1,0-3,0 cm comprimento, 2,0-4,0 mm largura, nervação hifódroma, evidente nas duas faces foliares, face adaxial tomentosa, tricomas estrelados, raio porrecto presente, creme, sésseis, face abaxial lepidota, tricomas estreladolepidotos, raios laterais parcialmente unidos (40-50\% do comprimento total), raio porrecto ausente, creme a ferrugíneos, sésseis; pecíolos 0,8-2,0 mm comprimento Inflorescências racemos unissexuados, 1,5-3,5 cm comprimento, lepidotos, tricomas dentado-lepidotos, raios laterais parcialmente unidos (ca. $80 \%$ do comprimento total), raio porrecto presente, creme a ferrugíneos, sésseis; brácteas inteiras, persistentes, 1,0-3,0 mm comprimento, lineares, ápice agudo, face abaxial lepidota, tricomas estrelado-lepidotos, raios laterais parcialmente unidos (40-50\% do comprimento total), raio porrecto ausente, creme a creme-amarelados, sésseis, face adaxial glabra. Flores estaminadas alvas, 5,0-6,0 mm comprimento; pedicelos 1,5-3,0 mm comprimento; sépalas 1,5-3,0 mm comprimento, cartáceas, ovais, ápice acuminado, face abaxial lepidota, tricomas estrelado-lepidotos, raios laterais parcialmente unidos (40-50\% do comprimento total), raio porrecto ausente, creme a ferrugíneos, sésseis, face adaxial glabra; pétalas 2,0-3,0 mm comprimento, cartáceas, lanceoladas, ápice agudo, metade proximal da margem vilosa, tricomas simples, alvos, face abaxial pubescente, tricomas estrelados, face adaxial glabra; estames (11-)12-16, filetes ca. 3,0 mm comprimento, filiformes, pubescentes, tricomas simples, alvos a creme, anteras ca. $1,5 \mathrm{~mm}$ comprimento, conectivos pubescentes, tricomas estrelados, alvos a creme; receptáculo tomentoso, tricomas simples, alvos; disco 5-lobado. Flores pistiladas esverdeadas, 6,0-7,0 $\mathrm{mm}$ comprimento; pedicelos 1,0-2,5 mm comprimento; sépalas desiguais, três menores, 2,5-3,5 mm comprimento, duas maiores, 3,0-5,0 mm comprimento, coriáceas, oblongas a triangulares, ápice agudo a acuminado, face abaxial lepidota, tricomas estrelado-lepidotos, raios laterais parcialmente unidos (40-50\% do comprimento total), raio porrecto ausente, creme, sésseis, metade distal da face adaxial tomentosa, tricomas estrelados, raio porrecto presente, alvos, sésseis; pétalas presentes, reduzidas; disco 5-lobado; ovário lepidoto, tricomas estrelado-lepidotos, raios laterais parcialmente unidos (40-50\% do comprimento total), raio porrecto ausente, creme-esverdeados a ferrugíneos, sésseis; estiletes bibífidos, primeira ramificação na base, segunda ramificação no quarto distal, lepidotos, tricomas estrelado-lepidotos, raios laterais parcialmente unidos (40-50\% do comprimento total), raio porrecto ausente, creme a ferrugíneos, sésseis; regiões estigmáticas 12, glabras. Frutos ca. 5,0 mm comprimento, ca. 3,0 mm largura; sementes ca. 3,0 mm comprimento, ca. 2,0 mm largura, elipsóides, testa castanha, lisa.

Distribuição geográfica e hábitats: Croton eskuchei é conhecida apenas de localidades próximas dos rios Paraguai e Paraná. Ocorre, no Paraguai, no Departamento Central, no Lago e Esteros de Ypoá e nas antigas dunas ao sul do Departamento de Ñeembucú (Ahumada 1999). E, na Argentina, sobre depósito arenoso eólico da Isla Toledo, em Corrientes e, no Paso Naranjito (Departamento de Ituizangó), sobre dunas do rio Paraná (Ahumada 1999), em regiões com vegetação campestre.

Fenologia: Flores e frutos foram observados de outubro a fevereiro (Ahumada 1999).

Material examinado: Argentina: Corrientes: Ituizangó: arroio Santa Isabel e rota 12, 9 dez. 1987 (fl), R. Vanni \& A. Randovancich 979 (CTES n.v., MO); Paso Naranjito, próximo ao Country, após o Camping Mirador, $27^{\circ} 32^{\prime} 14,1^{\prime}$ ' S e 56 40' 27,9” W, elev. $71 \mathrm{~m}$, 14 fev. 2004 (fl, fr), L.R. Lima, M.A. Farinaccio \& A.B. Junqueira 340 (SP, SPF, WIS).

Croton eskuchei foi descrita por Ahumada (1999) que a incluiu na seção Lamprocroton devido ao hábito arbustivo e ao indumento lepidoto presente na planta toda. Segundo a autora, C. eskuchei é uma espécie bastante semelhante a C. cinerellus Müll. Arg. da qual pode ser diferenciada por ser dióica e apresentar tricomas dos ramos e da face abaxial das folhas diferentes. Além disso, C. cinerellus ocorre somente no Brasil, nos estados de Minas Gerais e Mato Grosso do Sul. De acordo com Ahumada (1999), Ibarrola coletou C. eskuchei pela primeira vez em Isla Toledo em 1944 e a espécie foi coletada pela segunda vez, na mesma localidade, depois de mais de 50 anos, pelo Dr. Ulrich Eskuche e o epíteto específico é uma homenagem ao segundo coletor.

A prancha de C. eskuchei apresentada no protólogo é bastante completa com hábito, detalhes do indumento e flores estaminada e pistilada e por isso a espécie não foi ilustrada no presente trabalho.

12. Croton hypoleucus Schltdl., Linnaea 19: 246. 1847. Tipo: [México], 'Inter Zimapan et S. José del Oro', jun., Schiede [1063] (holótipo, HAL!; isótipo, B!).

Croton parvulus Müll. Arg., Linnaea 34: 106. 1865. Tipo: 'In America calida', s.c., (holótipo, G!). syn. nov.

Figuras 6a-e; 16e.

Subarbustos a arbustos, 0,25-1,5 m altura, monóicos; caule lepidoto, tricomas dentado-lepidotos, raios laterais parcialmente unidos (ca. 70\% do comprimento total), raio porrecto ausente, creme, dourados, creme-acinzentados a creme-amarelados, sésseis. Folhas discolores, inteiras, cartáceas a subcoriáceas, elípticas, ovais a largamente elípticas, ápice agudo, acuminado a arredondado, base obtusa, arredondada a quase truncada, raramente aguda, margem inteira, lâmina 0,7-4,7 cm comprimento, 0,5-1,7 cm largura, nervação broquidódroma, nervura primária impressa na face adaxial, saliente na abaxial, nervuras secundárias pouco evidentes na face adaxial, salientes na abaxial, face adaxial glabrescente, tricomas estrelados, raio porrecto ausente, alvos a creme, sésseis, face abaxial lepidota, tricomas dentado-lepidotos, raios laterais parcialmente unidos (ca. 70\% do comprimento total), raio porrecto ausente, alvos, creme a amarelados, sésseis a curto-estipitados; pecíolos 2,0-10,0 mm comprimento Inflorescências racemos bissexuados, 0,9-3,0 cm comprimento, lepidotos, tricomas dentado-lepidotos, raios laterais parcialmente unidos (ca. 70\% do comprimento total), raio porrecto ausente, creme, dourados a creme-amarelados, sésseis; brácteas inteiras, persistentes, 0,3-0,8 mm comprimento, triangulares, ápice agudo, face abaxial lepidota, tricomas dentado-lepidotos, raios laterais parcialmente unidos (ca. $70 \%$ do comprimento total), raio porrecto ausente, dourados, ferrugíneos a acastanhados, sésseis, face adaxial glabra. Flores estaminadas creme, esverdeadas a amareladas, 1,5-3,0 mm comprimento; pedicelos 0,5-1,0 mm comprimento; sépalas 1,5-3,0 mm comprimento, cartáceas a subcoriáceas, ovais, ápice agudo, face abaxial lepidota, tricomas dentado-lepidotos, raios laterais parcialmente unidos (ca. 70\% do comprimento total), raio porrecto ausente, creme a dourados, sésseis, face adaxial glabra; pétalas 2,0-3,0 mm comprimento, membranáceas, estreitamente elípticas, ápice agudo a arredondado, metade proximal da margem vilosa, tricomas simples, alvos, faces abaxial e adaxial glabras; estames 12-16, filetes 1,0-2,0 mm comprimento, levemente subulados, glabros, anteras ca. 1,0 mm comprimento, conectivos glabros; receptáculo tomentoso, tricomas simples, alvos; disco 5-lobado. Flores pistiladas esverdeadas a acastanhadas, 2,0-4,0 $\mathrm{mm}$ comprimento; pedicelos 0,2-1,0 mm comprimento; sépalas iguais, ca. 2,0 mm comprimento, coriáceas, triangulares, ápice acuminado, face abaxial lepidota, tricomas dentado-lepidotos, raios laterais parcialmente unidos (ca. $70 \%$ do comprimento total), raio porrecto ausente, creme a dourados, sésseis, face adaxial glabra; pétalas presentes, reduzidas; disco 5-lobado; ovário lepidoto, tricomas dentado-lepidotos, raios laterais parcialmente unidos (ca. 70\% do comprimento total), raio porrecto ausente, creme a dourados, sésseis; estiletes bífidos, ramificados desde a base, lepidotos, tricomas dentado-lepidotos, raios laterais 
parcialmente unidos (ca. $70 \%$ do comprimento total), raio porrecto ausente, creme a dourados, sésseis; regiões estigmáticas 6 , glabras. Frutos ca. 6,0 mm comprimento, ca. 7,0 mm largura; sementes ca. 4,5 mm comprimento, ca. 3,5 mm largura, elipsóides, testa castanhoescura, rugosa.

Distribuição geográfica e hábitats: Croton hypoleucus, assim como $C$. ehrenbergii, é uma espécie endêmica do México, ocorrendo em diversas províncias. É freqüente nos tipos de vegetação denominados chaparral ou matorral, sempre junto a afloramentos rochosos, em solo escasso e pedregoso e, na maioria das vezes, sobre afloramentos de calcário, em solo negro. Pode ser encontrada também em bosque de Pinus cembroides Gord., em áreas onde o solo é vermelho e junto a populações de Pinus resinosa Roezl, em regiões de matorral. Todos os materiais aqui examinados são provenientes de regiões com altitude próximas ou superiores que os $2.000 \mathrm{~m}$ de altura, entre 1.700 e $2.200 \mathrm{~m}$.

Fenologia: Flores não foram observadas apenas nos meses de abril e dezembro. Frutos foram vistos somente em agosto.

Material examinado: México: s.d. (fl), Salzmann s.n. (B s.n.). Coahuila de Zaragoza: Coahuila: Sierra de la Paila, Mina El Aguirreno, lado norte da Sierra de la Paila, $26^{\circ} 5^{\prime} 30^{\prime \prime} \mathrm{N} \mathrm{e} 101^{\circ} 36^{\prime} \mathrm{W}$, elev. 1.700-2.200 m, 5 jul. 1973 (fl), M.C. Johnston, T.L. Wendt \& F. Chiang 11710 (F, MO, NY). Galeana: Rayones: ca. de $5 \mathrm{~km}$ de Rayones, elev. 1.600 m, 27 jun. 1994 (fl), G.B. Hinton 24463 (NY). Guanajuato: Atarjea: Cuicillos, elev. 2300 m, 14 ago. 1990 (fl), E. Ventura \& E. López 8270 (MEXU). Hidalgo: elev. 2.000 m, 6 set. 1979 (fl), R. Hernández M. 3701 (MEXU). Cardonal: cerro Boludo de Tolantongo, $42 \mathrm{~km}$ a nordeste de Ixmiquilpan, 31 ago. 1976 (fl), F.G. Medrano et al. 9612 (MEXU, MO). Ixmiquilpan: Tajshado, ca. de $10 \mathrm{~km}$ a sudeste de Ixmiquilpan, elev. ca. $1.800 \mathrm{~m}$, s.d. (fl), J. Rzedowski 9479 (MEXU); jul.-set. 1905 (fl), C.A. Purpus et al. 1451 (MO, NY); jul. 1908 (fl), C.A. Purpus 3451 (NY); nov. 1910 (fl), C.A. Purpus 5062 (MO, NY); próximo ao km 146, a sudeste de Ixmiquilpan, fora da cidade do México, Laredo Highway, 4 ago. 1943 (fl), C.L. Lundell \& A.A. Lundell 12334 (NY); id., a sudoeste de Ixmiquilpan, fora da cidade do México, Laredo Highway, 4 ago. 1943 (fl), C.L. Lundell \& A.A. Lundell 12335 (NY); $10 \mathrm{~km}$ a sudeste de Ixmiquilpan, elev. 1.900 m, 20 mar. 1966 (fl), L. González 3379 (MO, NY); 8,5 km a sudeste de Ixmiquilpan, elev. $2000 \mathrm{~m}, 12$ ago. 1965 (fl), L.G. Quintero 2791 (WIS); Daxdhó, Cañada Chica, 12 km ao sul de Ixmiquilpan, elev. 2200 m, 25 jun. 1981 (fl), R. Hernández $M$. et al. 6215 (MEXU); ca. 14 milhas ao norte de Zimapán, na highway 85, elev. 1850 m, 5 jan. 1982 (fl), J. Bacon \& M. Dillon 1730 (F). Zimapán: km 231,5 da highway acima de Zimapán, 16 jul. 1943 (fl), C.L. Lundell 12273 (MO, NY); próximo a Puerto Ing. Isidro Díaz, km 230-235 na highway entre Zimapán e Jacala, elev. 2.070 m, 7 jul. 1948 (fl), H.E. Moore Jr. \& C.E. Wood Jr. 3768 (WIS); Sierra Madre Oriental, na highway 85, entre Zimapán e Jacala, $35,5 \mathrm{~km}$ na estrada a nordeste para Zimapán, $11 \mathrm{~km}$ na estrada a noroeste de Los Duraznos, $20^{\circ} 50^{\prime} \mathrm{N}$ e $99^{\circ} 14^{\prime}$ W, elev. 1.980 m, 2 ago. 1979 (fl, fr), G. Diggs \& C. Corcoran 2357 (WIS); $10 \mathrm{~km}$ ao norte de Zimapán, próximo à Mina de San Miguel, elev. 2.200 m, 28 jun. 1981 (fl), R. Hernández et al. 6282 (MEXU). Oaxaca: Chocani: vizinhança de San Luis Tultilanapa, jul. 1908 (fl), C.A. Purpus 3457 (F); 1 km a oeste de Chocani, 13 km a sudeste de Tamazulapan, 23 fev. 1982 (fl), C.A.G. Mendoza 900 (MEXU, MO). Puebla: Caltepec: vertente norte da "Mesa de Pala", a sudeste de Acatepec, elev. $2.180 \mathrm{~m}$ altura, 14 ago. 1984 (fl), P. Tenório L. \& C. Romero T. 6880 (MEXU). Chilac: Barranca Tlacuilosto, a sudoeste de San Juan Atzingo, 18 17' N e 97² 23' W, 24 set. 1990 (fl), A. Salinas T. et al. 5802 (MEXU, MO). Teontepec: $5 \mathrm{~km}$ a sudeste de San Pedro Nopala, $18^{\circ} 30^{\prime}$ N e 97 36' W, elev. 2.070 m, 26 out. 1986 (fl), P. Tenorio L. \& D. Frame 12255 (F). Queretaro de Arteaga: Cadereyta: $5 \mathrm{~km}$ ao sul de Vizanón, no caminho para Cadereyta, elev.
2300 m, 16 ago. 1989 (fl), J. Rzedowski 48692 (MEXU). San Luis Potosi: San Pedro: Sierra Madre Oriental, elev. 2.150-2.200 m, 29 jul. 1934 (fl), F.W. Pennell 17736 (NY). Tamaulipas: Bustamante: 18 km a sudeste de Bustamante, próximo de La Pesita e Tula, $23^{\circ} 21^{\prime} \mathrm{N}$ e $99^{\circ} 40^{\prime} \mathrm{W}$, elev. 1.700 m, 20 maio 1973 (fl), M.C. Johnston, T.L. Wendt \& F. Chiang 11159 (F, MO, NY). Ciudad Victoria: Carretera Victoria - San Luis Postosi, 8 milhas ao sul de Palimillas, 20 jul. 1985 (fl), S. Ginzbarg \& A. Whittemore 118 (K). Palmillas: 14 km a sudeste de Palmillas, a oeste do rancho El Balcon, elev. $1.700 \mathrm{~m}$, 24 set. 1977 (fl), F. González-Medrano, A. Sandoval \& P. Zavaleta 9984 (MEXU). Tula: $34 \mathrm{~km}$ ao norte de Tula e 5,5 km ao norte de La Presita, na highway para Palmillas, $23^{\circ} 16^{\prime} \mathrm{N}$ e $99^{\circ} 39^{\prime} \mathrm{W}$, elev. 1.700 m, 20 maio 1973 (fl), M.C. Johnston, T.L. Wendt \& F. Chiang 11144 (MEXU, NY).

Croton hypoleucus é bastante semelhante, morfologicamente, a $C$. ehrenbergii, entretanto enquanto na segunda a face adaxial das folhas é lepidota, com indumento formado por tricomas cujos raios laterais são unidos em 30 a $40 \%$ do seu comprimento total, na primeira, além dos tricomas serem diferentes por serem estrelados, eles caem à medida que as folhas se desenvolvem deste modo, em um mesmo indivíduo pode-se observar desde folhas tomentosas até aquelas completamente glabras. A face abaxial das folhas é, in sicco, amarelada. Croton hypoleucus é aqui tratada como um representante de Lamprocroton pelo fato de os caracteres morfológicos coincidirem com aqueles previstos para os representantes da seção. Porém, deve-se ressaltar que flores com 16 estames ocorrem com baixa frequiência nessa espécie.

Webster (1993) citou C. hypoleucus como uma das espécies representativas da seção Lamprocroton. O indumento lepidoto presente em quase toda a planta como ramos, face abaxial das folhas, inflorescências, sépalas, entre outras, bem como os estiletes bífidos são congruentes com o que o autor (Webster 1993) reconheceu para os membros desta seção. Nossa posição é concordante com a de Webster (1993), porém, como comentado para C. ehrenbergii, a distribuição geográfica de C. hypoleucus diverge daquela observada na maioria das espécies da seção Lamprocroton e, talvez, um estudo filogenético detalhado do gênero Croton que inclua um número considerável de terminais possa revelar outro posicionamento para esse táxon.

13. Croton imbricatus L.R. Lima \& Pirani, Kew Bull. 63 (1), no prelo. Tipo: 'Brasil, Bahia, Rio de Contas, Cachoeira do Fraga, $13^{\circ} 35$ ' 56" S e $41^{\circ} 49^{\prime} 36^{\prime \prime}$ W, elev. 950 m', 31 jan. 2003 (fl), L.R. Lima et al. 257 (holótipo, SPF; isótipos, SPF, WIS).

Figuras 7a-g; $16 f$.

Subarbustos a arbustos, 0,6-3,0 m altura, monóicos; caule lepidoto, tricomas lepidoto-típicos, raios laterais totalmente unidos, raio porrecto ausente, acastanhados a dourados, sésseis. Folhas levemente discolores, inteiras, papiráceas a cartáceas, elípticas, ovais a, raramente, obovais, ápice agudo, às vezes, arredondado, mucronulado, base aguda, margem inteira, lâmina 0,9-4,0 cm comprimento, 0,5-1,5 cm largura, nervação broquidódroma, nervura primária evidente na face adaxial, bastante saliente na abaxial, nervuras secundárias pouco evidentes nas duas faces foliares, face adaxial lepidota, tricomas lepidoto-típicos, raios laterais totalmente unidos, raio porrecto presente, verde-claro a verde-acinzentados, sésseis, face abaxial lepidota, tricomas lepidoto-típicos, raios laterais parcialmente unidos (ca. 95\% do comprimento total), raio porrecto ausente, creme, dourados, castanhos a cinéreos, região central acastanhada a ferrugínea, sésseis; pecíolos 1,5-7,0 mm comprimento Inflorescências racemos bissexuados, $0,5-1,5 \mathrm{~cm}$ comprimento, lepidotos, tricomas lepidoto-típicos, raios laterais totalmente unidos, raio porrecto ausente, creme, dourados a acastanhados, sésseis; brácteas inteiras, persistentes, 0,5-1,5 mm comprimento, triangulares, ápice agudo, 
margem vilosa, tricomas simples, creme, faces abaxial e adaxial glabras. Flores estaminadas alvas, creme, amareladas, paleáceas, esverdeadas a creme-esverdeadas, 2,0-5,0 $\mathrm{mm}$ comprimento; pedicelos 1,0-3,0 mm comprimento; sépalas 1,5-2,0 mm comprimento, coriáceas, ovais a largamente ovais, ápice agudo, às vezes, ciliado, tricomas simples, alvos, face abaxial lepidota, tricomas lepidototípicos, raios laterais totalmente unidos, raio porrecto ausente, dourados, sésseis, face adaxial glabra a tomentosa, tricomas simples, adpressos, alvos, adpressos; pétalas 2,0-3,5 mm comprimento, membranáceas, oblongas a estreitamente oblongas, ápice arredondado, ciliado, tricomas simples, alvos, metade proximal da margem vilosa, tricomas simples, alvos, faces abaxial e adaxial glabras; estames 11 , filetes $1,8-4,0 \mathrm{~mm}$ comprimento, levemente subulados, glabros, anteras 0,5-1,0 mm comprimento, conectivos glabros; receptáculo tomentoso, tricomas simples, alvos; disco 5-lobado. Flores pistiladas esverdeadas a paleáceas, 2,0-4,5 $\mathrm{mm}$ comprimento; pedicelos 0,5-1,0 mm comprimento; sépalas iguais, 2,0-2,5 mm comprimento, coriáceas, ovais, ápice agudo, face abaxial lepidota, tricomas lepidoto-típicos, raios laterais totalmente unidos, raio porrecto ausente, dourados a acastanhados, sésseis, face adaxial glabra ou com a metade distal tomentosa, tricomas estrelados, raio porrecto ausente, alvos, sésseis; pétalas ausentes; disco 5-lobado; ovário lepidoto, tricomas lepidoto-típicos, raios laterais totalmente unidos, raio porrecto ausente, acastanhados, sésseis; estiletes bífidos, ramificados desde a base, glabros; regiões estigmáticas 6, glabras. Frutos 6,0-8,0 mm comprimento, 5,0-7,5 mm largura; sementes ca. 4,0 mm comprimento, ca. 3,0 mm largura, elipsóides a largamente elipsóides, testa castanha, lisa.

Distribuição geográfica e hábitats: Trata-se de uma espécie endêmica do estado da Bahia onde ocorre em diversos dos municípios que compõem a Chapada Diamantina, em áreas de caatinga herbáceo-arbustiva, em solo areno-pedregoso e com afloramentos rochosos esparsos, geralmente na região de transição entre a caatinga e o campo rupestre. É freqüente também nas regiões de cerrado aberto com afloramentos rochosos além de ocorrer próxima a rios e em fendas de rochas. No município de Abaíra (BA) pode ser encontrada em regiões de carrasco com solo arenoso e rochas. Desenvolve-se, principalmente, em regiões com altitudes superiores aos $800 \mathrm{~m}$.

Fenologia: Floresce praticamente durante o ano todo, exceto em junho. Frutos foram vistos em março e abril.

Material examinado: Brasil: Bahia: Abaíra: Mata da Pedra Grande, $13^{\circ} 14^{\prime} \mathrm{S}$ e $41^{\circ} 54^{\prime} \mathrm{W}$, elev. 1.500-1.550 m, 2 mar. 1992 (fr), T. Laessoe \& P.T. Sano H 52513 (CEPEC n.v., HUEFS n.v., K n.v., MO, NY, SPF n.v.); estrada Catolés-Abaíra, ca. 4 km da Catolés, estrada velha do engenho, $13^{\circ} 18^{\prime} \mathrm{S}$ e $41^{\circ} 50^{\prime} \mathrm{W}$, elev. $1.000 \mathrm{~m}, 13$ nov. 1992 (fl), W. Ganev 1423 (SP); Marques, caminho ligando Marques à estrada velha da Furna, $13^{\circ} 22^{\prime} \mathrm{S}$ e $41^{\circ}$ 47' W, elev. $1.050 \mathrm{~m}, 6$ nov. 1993 (fl),

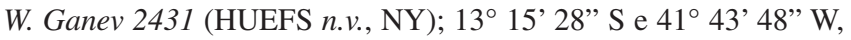
elev. 776 m, 31 out. 1996 (fl), L.P. Queiroz \& M.M. Silva 3836 (ALCB, HRB, SP, SPF). Caetité: distrito de Brejinho das Ametistas, ca. de $3 \mathrm{~km}$ a sudoeste da sede do distrito, $18 \mathrm{fev} .1992$ (fl), A.M. Carvalho et al. 3744 (CEPEC n.v., MBM, MO, NY, SP); Santa Luzia, 18 km da cidade, $14^{\circ} 8^{\prime}$ ' 19" S e 42 27' 33" W, 10 mar. 1994 (fl), V.C. Souza et al. 5426 (SPF); Brejinho das Ametistas, estrada Brejinho das Ametistas-Caetité, 22 maio 1999 (fl), V.C. Souza et al. 23054 (ESA, SPF). Ibicoara: Chapada Diamantina, encosta da Serra da Jibóia, $13^{\circ} 26^{\prime} \mathrm{S}$ e $41^{\circ} 30^{\prime} \mathrm{W}$, elev. $1.230 \mathrm{~m}, 10$ jul. 2000 (st), M.A. Nóbrega 60 (SPF); Chapada Diamantina, encosta da Serra da Jibóia, $13^{\circ} 26^{\prime} \mathrm{S}$ e $41^{\circ} 30^{\prime} \mathrm{W}$, elev. 1.230 m, 11 jul. 2000 (st), M.A. Nóbrega 70 (SPF); Chapada Diamantina, Pediplano Central, $13^{\circ} 14^{\prime} \mathrm{S}$ e $41^{\circ} 29^{\prime} \mathrm{W}$, elev. 1.040 m, 21 nov. 2000 (fl), M.A. Nóbrega 250 (SPF). Jussiape: à margem do Rio de Contas, próximo da cidade, Cachoeira do Fraga, 16 fev. 1987 (fl), R.M. Harley et al. 24341 (F, K., SP, SPF). Livramento do Brumado: subida para Rio de Contas, elev. 850 m, 6 abr. 1992 (fl), G. Hatschbach, M. Hatschbach \& E. Barbosa 56674 (G, K, MBM). Mucugê: estrada Mucugê-Guiné, a 5 km de Mucugê, 7 set. 1981 (fl), A. Furlan et al. CFCR 1979 (K, SPF); 16 dez. 1996 (fl), L.M.C. Gonçalves 254 (HRB). Rio de Contas: Serra do Rio de Contas, entre 2,5 a $5 \mathrm{~km}$ ao sul de Rio de Contas, na estrada a oeste para Livramento, próximo ao rio Brumado, $13^{\circ} 36^{\prime} \mathrm{S}$ e $41^{\circ} 50^{\prime} \mathrm{W}$, elev. ca. 980 m, 28 mar. 1977 (fl), R.M. Harley et al. 20080 (K, NY, SPF, UEC); estrada para a Cachoeira do Fraga, no rio Brumado, a $3 \mathrm{~km}$ de Rio de Contas, 22 jul. 1981 (fl), A. Furlan et al. CFCR 1685 (K, SPF); Cachoeira do Fraga, 18 set 1989 (fl), G. Hatschbach, M. Hatschbach \& V. Nicolack 53442 (MBM); Poço do Ciência, margem do Rio da Água Suja, divisa Rio de Contas-Abaíra (Arapiranga), $13^{\circ} 49^{\prime} \mathrm{S}$ e $42^{\circ}$ 26' W, elev. 1.020 m, 8 ago. 1993 (fl), W. Ganev 2054 (HUEFS n.v., NY); Serra do Tombador, $13^{\circ} 37^{\prime} 50^{\prime \prime} \mathrm{S}$ e $41^{\circ} 47^{\prime} 42^{\prime}$ 'W, elev. 1.100 m, 19 nov. 1996 (fl, fr), N. Roque et al. 4493 (ALCB, HRB, $\mathrm{K}, \mathrm{SPF}$ ); arredores da cidade, $13^{\circ} 35^{\prime} 23^{\prime \prime} \mathrm{S}$ e $41^{\circ} 48^{\prime} 80^{\prime \prime} \mathrm{W}$, elev. 840 m, 20 out. 1997 (fl), M. Alves et al. 1200 (HRB, UFP n.v.); Serra de Rio de Contas, arredores da cidade, $13^{\circ} 57^{\prime} 75^{\prime}$ ' S e $41^{\circ} 48^{\prime} 44^{\prime \prime} \mathrm{W}$, 20 out. 1997 (fl), M. Alves et al. 1232 (HRB, UFP n.v.); trilha da Cachoeira do Fraga, 13 nov. 1998 (fl), M.M. Silva et al. 136 (HUEFS n.v., SP); 13 nov. 1998 (fl), M.M. Silva et al. 155 (HUEFS n.v., SP); estrada Livramento-Rio de Contas, a $3 \mathrm{~km}$ de Rio de Contas, 10 abr. 1999 (fl, fr), R.C. Forzza et al. 1116 (CEPEC n.v., NY n.v., SP, SPF); estrada Real, $13^{\circ} 32^{\prime}$ S e $41^{\circ} 57^{\prime}$ W, 2 jan. 2000 (fl), A.M. Giulietti \& R.M. Harley 1632 (HUEFS n.v., K). Seabra: Serra do Bebedor, a 40 km de Seabra, elev. 1.090 m, 15 nov. 1983 (fl), G.C.P. Pinto et al. 415/83 (HRB, RB).

As folhas de C. imbricatus são levemente discolores com a face adaxial variando de verde-escura a verde-acinzentada e a face abaxial bastante cinérea ou apenas um pouco mais acinzentada ou prateada do que a adaxial. As duas faces foliares são cobertas por indumento lepidoto formado por tricomas tipicamente lepidotos, com raios laterais quase ou completamente unidos e região central ferrugínea facilmente visível a olho nu. Tal característica torna a espécie facilmente reconhecível em campo já que a região central dos tricomas aparece como nítidos pontos acastanhados. Na maioria das folhas, a nervação pode parecer hifódroma já que, por conta da densidade do indumento, as nervuras laterais tornam-se muito pouco evidentes, porém a análise de diversas coleções mostrou que a nervação em C. imbricatus é broquidódroma, tipo encontrado em vários dos representantes da seção Lamprocroton. Apesar de a inflorescência ser bissexuada, em muitos dos espécimes analisados há apenas um tipo de flor nos racemos. Tal fato ocorre devido ao fato de a protoginia ser um fenômeno comum no gênero; porém em algumas coleções podem-se observar inflorescências bissexuadas (Roque 4493, Harley 24341 e Ganev 1423). Trata-se de uma espécie bastante semelhante, vegetativamente, a $C$. erythroxyloides, pois ambas possuem as duas faces foliares lepidotas. No entanto, quando em flor, $C$. imbricatus pode ser distinguida da outra espécie supracitada, principalmente, pelas sépalas das flores pistiladas que são ovais e semelhantes entre si ao passo que, naquela, elas são, geralmente, espatuladas e bastante desiguais no tamanho. As brácteas também podem ser utilizadas como um caráter que distingue esses dois táxons pois em $C$. imbricatus elas são triangulares e glabras na face abaxial, ao passo que em C. erythroxyloides, variam de lanceoladas a estreitamente triangulares e possuem a face abaxial densamente lepidota.

Nos herbários, é bastante comum encontrar exsicatas de C. imbricatus identificadas como C. burchellii. Entretanto, a análise do material-tipo de $C$. burchellii e de outras coleções desse táxon não deixa dúvida de que as duas espécies devem ser consideradas entidades distintas, uma vez que o tamanho e forma das folhas, tipo de indumento, forma das sépalas das flores pistiladas, entre outras carac- 
terísticas, mostram-se são bastante diferentes entre elas. Além disso, enquanto $C$. burchellii ocorre, principalmente, em áreas de cerrado de Goiás, Tocantins e Maranhão, $C$. imbricatus é endêmica da Bahia e é encontrada, principalmente, junto a afloramentos rochosos.

14. Croton linearifolius Müll. Arg. in Mart. \& Eichl., Fl. bras. 11 (2): 142 1873. Tipo: [Brasil], 'Habitat in prov. Bahia, in Silvis Catingas, locis apricis ad Quemadas', Martius s.n. (holótipo, G!; isótipos, M 0086083 !, M 0089107!, M 0089108!; fotografias do isótipo, F!, G! ex M).

Figuras 6f-j; 17a.

Arbustos, 0,5-2,0 m altura, monóicos; caule lepidoto, tricomas lepidoto-típicos, raios laterais parcialmente unidos (ca. $80 \%$ do comprimento total), raio porrecto ausente, alvos a creme, região central castanha a ferrugínea, sésseis. Folhas fortemente discolores, inteiras, cartáceas, lanceoladas, estreitamente oblongas a estreitamente elípticas, ápice agudo, mucronulado, base aguda, margem inteira, lâmina 1,0-6,0 cm comprimento, 2,0-6,0 mm largura, nervação hifódroma, impressa na face adaxial, saliente na abaxial, face adaxial glabra, face abaxial lepidota, tricomas lepidoto-típicos, raios laterais parcialmente unidos (ca. $80 \%$ do comprimento total), raio porrecto ausente, creme, dourados a cinéreos, sésseis; pecíolos 1,0-5,0 mm comprimento Inflorescências racemos bissexuados, 1,0-5,5 cm comprimento, lepidotos, tricomas lepidoto-típicos, raios laterais parcialmente unidos (ca. de $80 \%$ do comprimento total), raio porrecto ausente, creme a dourados, sésseis; brácteas inteiras, persistentes, 1,0-2,5 mm comprimento, triangulares a estreitamente triangulares, ápice agudo, face abaxial lepidota, tricomas lepidoto-típicos, raios laterais parcialmente unidos (ca. 80\% do comprimento total), raio porrecto ausente, alvos a creme, com região central ferrugínea, sésseis, face adaxial glabra. Flores estaminadas alvas a esverdeadas, 2,0-3,5 mm comprimento; pedicelos 1,5-3,0 mm comprimento; sépalas 1,5-2,5 mm comprimento, cartáceas, ovais, ápice agudo, ápice e margem ciliados, tricomas simples, alvos, face abaxial lepidota, tricomas lepidoto-típicos, raios laterais parcialmente unidos (ca. 80\% do comprimento total), raio porrecto presente, creme a dourados, sésseis, face adaxial glabra; pétalas 1,5-2,0 mm comprimento, membranáceas, espatuladas a oblanceoladas, ápice agudo, ápice e metade distal da margem ciliados, tricomas simples, alvos, metade proximal da margem vilosa, tricomas simples, alvos, faces abaxial e adaxial glabras; estames 10-12, filetes 1,5-2,5 mm comprimento, filiformes, glabros, anteras 0,3-1,0 mm comprimento, conectivos glabros; receptáculo tomentoso, tricomas simples, alvos; disco 5-lobado. Flores pistiladas creme-esverdeadas, 2,0-4,0 mm comprimento; pedicelos 1,5-2,0 mm comprimento; sépalas iguais, 2,0-2,5 mm comprimento, coriáceas, triangulares, ápice acuminado, face abaxial lepidota, tricomas lepidoto-típicos, raios laterais parcialmente unidos (ca. $80 \%$ do comprimento total), raio porrecto ausente, creme a dourados, sésseis, face adaxial glabra; pétalas presentes, reduzidas; disco 5-lobado; ovário lepidoto, tricomas lepidoto-típicos, raios laterais parcialmente unidos (ca. $80 \%$ do comprimento total), raio porrecto ausente, creme, dourados a amarelados, sésseis; estiletes bífidos, ramificados desde a base, glabros; regiões estigmáticas 6, glabras. Frutos ca. 4,5 mm comprimento, ca. 4,0 mm largura; sementes ca. 4,0 mm comprimento, ca. 2,5 mm largura, elipsóides, testa castanha a castanho-alaranjada, levemente rugosa.

Distribuição geográfica e hábitats: Apesar da coleção-tipo de C. linearifolius ter sido coletada no estado da Bahia, os demais materiais aqui examinados desse táxon são provenientes da região Sul do Brasil, dos estados do Paraná e de Santa Catarina. Nessa região, ocorre, especialmente, em locais com baixa drenagem como campo úmido e próxima a brejos, e também, na borda de matas degradadas, a cerca de $750 \mathrm{~m}$ de altura.
Fenologia: Flores foram observadas em janeiro, fevereiro, abril, outubro e novembro. Frutos foram vistos apenas em abril.

Material examinado: Brasil: Paraná: União da Vitória: São Cristóvão, 18 nov. 1972 (fl), G. Hatschbach 30678 (G, MBM, MO, W); estrada para o bairro São Cristóvão, antes da ponte sobre o rio Iguaçu, 14 abr. 2004 (fl, fr), L.R. Lima \& J.M. Silva 353 (MBM, SPF, WIS). Santa Catarina: Ponte Alta: Rod. SC-425, trevo para Curitibanos, 11 fev. 1996 (fl), O.S. Ribas, J. Cordeiro \& C.B. Poliquesi 1211 (G, MBM, W). Porto União: elev. 750 m, 6 jan. 1962 (fl), R. Reitz \& R.M. Klein 11667 (NY); elev. 750 m, 26 out. 1962 (fl), R. Reitz \& R.M. Klein 13634 (MBM, NY).

Croton linearifolius apresenta hábito bastante semelhante ao de C. burchellii, ambas as espécies possuem folhas estreitas variando de lanceoladas a estreitamente elípticas. Entretanto, enquanto em C. burchellii a face adaxial das folhas é indumentada, com tricomas estrelado-lepidotos cujos raios laterais são unidos em 40 a 50\% do comprimento total, em $C$. linearifolius, a face adaxial das folhas é completamente glabra. Além disso, na primeira as sépalas das flores pistiladas são desiguais no tamanho ao passo que na segunda elas são semelhantes entre si. Ressalte-se ainda que $C$. burchellii ocorre em regiões de cerrado de Goiás, Tocantins, Piauí e Maranhão e, C. linearifolius, atualmente, parece ocorrer somente na região mais meridional do Brasil, nos estados do Paraná e de Santa Catarina.

Smith et al. (1988) identificaram, na Flora Ilustrada Catarinense, a coleção Reitz \& Klein 13634 como C. tenuissimus Baill. porém, a análise desse material leva a crer que sua identidade correta seja $C$. linearifolius já que, em $C$. uruguayensis, nome correto de C. tenuissimus, as inflorescências são unissexuadas e os tricomas da face abaxial das folhas possuem os raios laterais lepidoto-típicos, com raios laterais unidos em cerca de $90 \%$ do seu comprimento total, ao passo que em $C$. linearifolius eles são dentado-lepidotos.

15. Croton muellerianus L.R. Lima., Kew Bull. 63(1), no prelo. Tipo: 'Brasil, Paraná, Campina Grande do Sul, Pico Caratuva', 16 abr. 2004 (fl), L.R. Lima, J.M. Silva \& O.S. Ribas 358 (holótipo, SPF; isótipos, MBM, SP, WIS).

Figuras 8a-f; 17b.

Subarbustos a arbustos, 0,3-3,0 m altura, monóicos; caule lepidoto, tricomas lepidoto-típicos, raios laterais totalmente unidos, raio porrecto ausente, creme, dourados a acastanhados, sésseis. Folhas fortemente discolores, inteiras, coriáceas, largamente elípticas a largamente ovais, raramente obovais, ápice arredondado a obtuso, mucronulado, base obtusa, margem inteira, lâmina 1,2-3,6 cm comprimento, 0,9-2,3 cm largura, nervação broquidódroma, nervura primária impressa na face adaxial, saliente na abaxial, nervuras secundárias não evidentes nas duas faces foliares, face adaxial glabra, face abaxial lepidota, tricomas lepidoto-típicos, raios laterais parcialmente unidos (90-95\% do comprimento total), raio porrecto ausente, creme, dourados a creme-cinéreos, região central acastanhada a ferrugínea, sésseis; pecíolos 0,3-1,7 cm comprimento Inflorescências racemos bissexuados, 1,0-2,6 cm comprimento, lepidotos, tricomas lepidototípicos, raios laterais totalmente unidos, raio porrecto ausente, creme, dourados a acastanhados, sésseis; brácteas inteiras, persistentes, 0,5-1,5 mm comprimento, estreitamente triangulares, ápice agudo, face abaxial lepidota, tricomas lepidoto-típicos, raios laterais totalmente unidos, raio porrecto ausente, creme, dourados a acastanhados, sésseis, face adaxial glabra. Flores estaminadas alvas, creme a creme-esverdeadas, 2,0-5,0 mm comprimento; pedicelos 1,0-3,0 mm comprimento; sépalas 2,0-2,5 mm comprimento, coriáceas, ovais, ápice acuminado, face abaxial lepidota, tricomas lepidoto-típicos, raios laterais totalmente unidos, raio porrecto ausente, creme, acastanhados a dourados, sésseis, face adaxial glabra; pétalas 2,0-2,5 mm comprimento, subcartáceas, espatuladas, ápice agudo a levemente 
arredondado, ciliado, tricomas simples, alvos, metade proximal da margem vilosa, tricomas simples, alvos, face abaxial glabra, raramente lepidota, tricomas lepidoto-típicos, raios laterais parcialmente unidos (ca. $80 \%$ do comprimento total), raio porrecto ausente, alvos a creme, sésseis, face adaxial glabra; estames 10-11, filetes 1,0-2,0 mm comprimento, filiformes, glabros, anteras ca. $0,5 \mathrm{~mm}$ comprimento, conectivos glabros; receptáculo tomentoso, tricomas simples, alvos; disco 5-lobado. Flores pistiladas alvas, creme a acastanhadas, 3,07,0 mm comprimento; pedicelos ca. 1,0 mm comprimento; sépalas iguais, 2,5-5,0 mm comprimento, coriáceas, espatuladas, ápice agudo, face abaxial lepidota, tricomas lepidoto-típicos, raios laterais totalmente unidos, raio porrecto ausente, creme, dourados a acastanhados, sésseis, face adaxial glabra; pétalas presentes, reduzidas; disco inteiro; ovário lepidoto, tricomas lepidoto-típicos, raios laterais totalmente unidos, raio porrecto ausente, creme a dourados, sésseis; estiletes bífidos, ramificados a partir da metade distal, lepidotos, tricomas lepidoto-típicos, raios laterais totalmente unidos, raio porrecto ausente, creme a dourados, sésseis, regiões estigmáticas 6 , glabras. Frutos ca. 5,0 mm comprimento, ca. 4,0 mm largura; sementes ca. 3,0 mm comprimento, 2,0-2,5 mm largura, elipsóides, testa castanhoalaranjada a vinácea, lisa.

Distribuição geográfica e hábitats: Croton muellerianus é endêmica do estado do Paraná onde ocorre somente nos municípios de Campina Grande do Sul e Morretes. É encontrada na borda das matas nebulares, nas encostas dos morros e em campos de altitude, em locais com solo areno-pedregoso e junto a afloramentos rochosos. Está fortemente associada a localidades com altitudes elevadas já que todas as coleções analisadas são provenientes de ambientes com cotas altitudinais superiores aos $1.000 \mathrm{~m}$ atingindo até $2.600 \mathrm{~m}$ de altura.

Fenologia: Flores não foram observadas em abril, agosto e dezembro. Frutos foram vistos apenas no mês de março.

Material examinado: Paraná: Campina Grande do Sul: Pouso Torre, escarpa do Pico Paraná, 2 maio 1971 (fl), N. Imaguire 510 (MBM); Serra dos Órgãos, elev. 1.600 m, 4 jul. 1991 (fl), C.V. Roderjan $925 b$ (EFC n.v., MBM); Serra do Ibitiraquire, subida para o Pico Paraná, 14 jul. 1996 (fl), O.S. Ribas \& F.Schwerdt 1451 (MBM). Morretes: Serra Marumbi, Crista do Gigante, 22 out. 1946 (fl), O. Curial 542 (MBM, SP); Crista do Gigante, 22 out. 1946 (fl), G. Hatschbach 542 (PACA); id., Pico Olimpo, elev. 1.547 m, 15 jan. 1950 (fl), G. Hatschbach 1746 (MBM); id., 13 nov. 1970 (fl), G. Hatschbach 25385 (MBM); id., encosta do morro, 16 jun. 1974 (fl), R. Kummrow 591 (MBM, MO); id., picada frontal, 18 fev. 1982 (fl), G. Hatschbach 44586 (MBM, MO); id., Abrolhos, 5 set. 1993 (fl), M.C. Portes s.n. (MBM 171159); id., subida para o Pico Olimpo, elev. 1.300 m, 23 out. 1995 (fl), O.S. Ribas, E.P. Santos \& J. Cordeiro 926 (BHCB, ESA, G, MBM, SP, SPF); id., Pico Olimpo, 10 jan. 1996 (fl), O.S. Ribas, J.M. Silva \& E. Barbosa 943 (MBM, RB); id., Ponta do Tigre, 19 mar. 1997 (fl, fr), A Soares \& W. Maschio 176 (HFC n.v., MBM).

Croton muellerianus possui hábito muito ramificado, característica comum nos representantes da seção Lamprocroton. Pode ser distinguida das demais espécies da seção, especialmente, por possuir as folhas fortemente discolores com a face adaxial totalmente glabra. Possui as nervuras secundárias muito pouco evidentes, o que pode levar, num primeiro momento, a uma caracterização errônea do seu tipo da nervação já que apenas a nervura principal é evidente nas duas faces foliares. No campo, pode ser facilmente reconhecida, pois as folhas são quase que imbricadas e ficam voltadas para cima, praticamente eretas. Talvez isso confira proteção contra a incidência direta dos raios solares, já que $C$. muellerianus é freqüente em áreas abertas, com vegetação baixa, altamente expostas ao excesso de luminosidade. As escamas da face abaxial das folhas são, em geral, alvas, creme a cinéreas e possuem a região central ferrugínea visível a olho nu. As folhas variam bastante quanto à forma e ao tamanho, mas são, em geral, largamente ovais a largamente elípticas. Trata-se de uma espécie extremamente semelhante a $C$. dichrous, outro táxon da seção Lamprocroton e, muitas vezes, é identificada como tal. Ambas possuem a face adaxial das folhas, em geral, glabra e a face abaxial coberta por tricomas lepidoto-típicos, no entanto em C. muellerianus as folhas são mais largas e coriáceas e os tricomas da face abaxial das folhas possuem raios laterais mais unidos quando comparados aos de $C$. dichrous. Além disso, em $C$. muellerianus as sépalas das flores pistiladas são estreitamente espatuladas e semelhantes entre si, ao passo que em $C$. dichrous elas são ovais e, na maioria das vezes, desiguais no tamanho. A distribuição geográfica também auxilia na separação desses dois táxons pois C. muellerianus ocorre apenas no estado do Paraná enquanto $C$. dichrous é restrita à região Sudeste do Brasil, ocorrendo em Minas Gerais, no Rio de Janeiro e em São Paulo.

16. Croton myrianthus Müll. Arg., Linnaea 34: 138. 1865. Croton pallidulus var. myrianthus (Müll. Arg.) L.B. Smith \& S.F. Smith, Flora Ilustrada Catarinense: Euforbiáceas: 127. 1988. Tipo: 'In Brasilia Meridionali', s.d., Sellow s.n. (holótipo, B†; lectótipo, SP!; isolectótipo, SP!; fotografias do holótipo, MO!, NY!)

Figuras 9a-f; 17c.

Subarbustos a arbustos, 0,5-2,0 m altura, monóicos; caule lepidoto, tricomas lepidoto-típicos, raios laterais parcialmente unidos (ca. de $90 \%$ do comprimento total), raio porrecto presente, creme, dourados a ferrugíneos, sésseis. Folhas fortemente discolores, inteiras, cartáceas, elípticas, obovais, oblongas a estreitamente elípticas, ápice arredondado, agudo a acuminado, mucronulado, base aguda, margem inteira, lâmina 1,0-2,5 cm comprimento, 0,6-1,2 cm largura, nervação broquidódroma, nervura primária impressa na face adaxial, saliente na abaxial, nervuras secundárias, em geral, não evidentes nas duas faces foliares, raramente, levemente salientes na face abaxial, face adaxial lepidota, tricomas lepidoto-típicos, raios laterais parcialmente unidos (ca. de $90 \%$ do comprimento total), raio porrecto presente, creme a dourados, sésseis, face abaxial lepidota, tricomas lepidoto-típicos, raios laterais parcialmente unidos (ca. de $90 \%$ do comprimento total), raio porrecto presente, creme a dourados, sésseis; pecíolos 2,5-4,0 mm comprimento Inflorescências racemos unissexuados, 0,9-1,5 cm comprimento, lepidotos, tricomas lepidoto-típicos, raios laterais parcialmente unidos (ca. de $90 \%$ do comprimento total), raio porrecto presente, creme, dourados a ferrugíneos, sésseis; brácteas inteiras, persistentes, 1,8-2,0 mm comprimento, lanceoladas a estreitamente triangulares, ápice agudo a acuminado, face abaxial lepidota, tricomas lepidoto-típicos, raios laterais parcialmente unidos (ca. de $90 \%$ do comprimento total), raio porrecto presente, creme a dourados, sésseis, face adaxial glabra. Flores estaminadas alvas, creme a creme-esverdeadas, 2,0-3,0 $\mathrm{mm}$ comprimento; pedicelos 2,0-3,0 mm comprimento; sépalas ca. 2,0 mm comprimento, subcoriáceas, ovais a triangulares, ápice agudo a acuminado, face abaxial lepidota, tricomas lepidoto-típicos, raios laterais parcialmente unidos (ca. de $90 \%$ do comprimento total), raio porrecto ausente, creme a dourados, sésseis, face adaxial glabra; pétalas ca. 2,5 mm comprimento, membranáceas, espatuladas a estreitamente elípticas, ápice agudo, ápice e metade distal da margem ciliados, tricomas simples, alvos, metade proximal da margem vilosa, tricomas simples, alvos, face abaxial glabra, raramente, região distal lepidota, tricomas lepidoto-típicos, raios laterais parcialmente unidos (ca. $90 \%$ do comprimento total), raio porrecto ausente, alvos a creme, sésseis, face adaxial glabra; estames 11(-15); filetes 1,8-2,0 mm comprimento, filiformes, glabros; anteras $0,8-1,0 \mathrm{~mm}$ comprimento, conectivos glabros; receptáculo tomentoso, tricomas simples, alvos; disco 5-lobado. Flores pistiladas creme a alvascentas, 4,0-5,0 mm comprimento; pedicelos 2,0-3,5 mm comprimento; sépa- 
las desiguais, duas menores, ca. 3,0 mm comprimento, três maiores, ca. 4,0 mm comprimento, coriáceas, ovais, ápice agudo, face abaxial lepidota, tricomas lepidoto-típicos, raios laterais parcialmente unidos (ca. de $90 \%$ do comprimento total), raio porrecto ausente, dourados, sésseis, face adaxial tomentosa, tricomas estrelados, raio porrecto presente, sésseis; pétalas ausentes; disco 5-lobado; ovário lepidoto, tricomas lepidoto-típicos, raios laterais parcialmente unidos (ca. de 90\% do comprimento total), raio porrecto ausente, dourados, sésseis; estiletes bífidos, ramificados desde a base ou, às vezes, a partir do quarto proximal, glabros; regiões estigmáticas 6, glabras. Frutos 4,0-5,0 mm comprimento, 4,0-5,0 mm largura; sementes ca. 3,5 mm comprimento, ca. 3,0 mm largura, elipsóides, testa castanha, lisa a levemente rugosa.

Distribuição geográfica e hábitats: Croton myrianthus ocorre apenas na região Sul do Brasil, nos estados do Paraná, Santa Catarina e Rio Grande do Sul, em altitudes que variam entre 700 e $1.700 \mathrm{~m}$. É encontrada, geralmente, em regiões de campo limpo ou campo sujo, próxima a afloramentos rochosos, na margem de rios, em locais úmidos, em capoeiras e na borda de matas nebulares, intactas ou desmatadas.

Fenologia: Foram observadas flores praticamente o ano inteiro, com exceção do mês de julho. Frutos ocorrem em fevereiro e março e de setembro a dezembro.

Material examinado: Brasil: Rio Grande do Sul: Água Azul: Água Azul para Caxias do Sul, 3 jan. 1947 (fl), E. Henz s.n. (PACA 35760). Bom Jesus: Taimbesinho para São Francisco de Paula, 7 fev. 1941 (fl, fr), B. Rambo s.n. (PACA 4330); id., 8 fev. 1941 (fl), B. Rambo s.n. (PACA 4316); Serra da Rocinha para Bom Jesus, 12 fev. 1941 (fl), B. Rambo s.n. (PACA 4624); Rio dos Touros para Bom Jesus, 13 jan. 1942 (fl), B. Rambo s.n. (PACA 8496); Serra da Rocinha para Bom Jesus, 14 jan. 1942 (fl), B. Rambo s.n. (PACA 8624); 15 jan. 1942 (fl), B. Rambo s.n. (PACA 8810); id., 28 fev. 1946 (fl), B. Rambo s.n. (PACA 32425); id., 14 fev. 1947 (fl), B. Rambo s.n. (PACA 35238); id., 18 jan. 1950 (fl), A. Sehnem s.n. (PACA 4240); id., 18 jan. 1950 (fl), B. Rambo s.n. (B, PACA 45352); id., 19 jan. 1950 (fl), A. Sehnem s.n. (B, PACA 4297); Taimbesinho para São Francisco de Paula, 30 jan. 1950 (fl), B. Rambo s.n. (NY s.n., PACA 45539); id., 18 dez. 1950 (fl, fr), B. Rambo s.n. (PACA 49354); id., 18 dez. 1950 (fl), B. Rambo s.n. (PACA 49407); id., elev. 1000 m, 19 dez. 1950 (fl), A. Sehnem 5139 (B, PACA); id., 21 fev. 1951 (fl), B. Rambo s.n. (PACA 50064); id., 21 fev. 1951 (fl), B. Rambo s.n. (PACA 50066); id., 21 fev. 1951 (fl, fr), B. Rambo s.n. (PACA 50076); id., 21 fev. 1951 (fl), B. Rambo s.n. (PACA 50106); id., 21 fev. 1951 (fl), B. Rambo s.n. (B, PACA 50160); id., 21 fev. 1951 (fl, fr), B. Rambo s.n. (PACA 50161); id., 21 fev. 1951 (fl), B. Rambo s.n. (B, PACA 50164, W); id., 9 ago. 1952 (fl), B. Rambo s.n. (PACA 52787); Serra da Rocinha para Bom Jesus, 3 fev. 1953 (fl), B. Rambo s.n. (B, PACA 53795); id., 3 fev. 1953 (fl), B. Rambo s.n. (B, PACA 53855); id., 3 fev. 1953 (fl), B. Rambo s.n. (PACA 53879); id., 3 fev. 1953 (fl), B. Rambo s.n. (PACA 53911); Taimbesinho para São Francisco de Paula, 20 fev. 1953 (fl), B. Rambo s.n. (B, PACA 53968); Taimbesinho para Bom Jesus, 20 fev. 1953 (fl), B. Rambo s.n. (B, PACA 53975); Itaimbezinho-Cambará, 28 abr. 1974 (fl), A. Allem et al. s.n. (ICN 26918); elev. 950 m, 1 out. 1987 (fl), L. Roth s.n. (ICN 68262). Cambará do Sul: Serra da Rocinha, 14 set. 1975 (fl), A. Alvarez et al. s.n. (ICN 30505); id., 14 set. 1975 (fl), M.L. Porto et al. 1611 (ICN); id., 28 out. 1983 (fl), B. Irgang s.n. (ICN 81213); Fortaleza, elev. 1.050 m, 27 set. 1992 (fl), R. Wasum 8656 (HUCS, G); id., elev. 1.000 m, 24 nov 1994 (fl), G. Hatschbach \& O.S. Ribas 61342 (MBM); id, elev. 1200 m, 1 mar. 1997 (fl), R. Wasum et al. s.n. (HUCS 12148, MBM 220245, MO 5696769); próximo a Cambará do Sul, 21 out. 1997 (fl, fr), R.S. Rodrigues 488 (ICN); id., 27 out. 1997 (fl, fr), R.S. Rodrigues 489 (ICN); Parque
Nacional da Serra Geral, trilha para a Pedra do Segredo, 10 abr. 2003 (fl), L.R. Lima \& M. Magenta 294 (MBM, RB, SPF, WIS); Parque Nacional da Serra Geral, cânion Fortaleza, 10 abr. 2003 (fl), L.R. Lima \& M. Magenta 295 (SPF, WIS); Parque Nacional do Itaimbezinho, "entrada de pesquisadores" (desativada), próximo à Mata de Araucária e à "casa do Fernando" (ex administrador do Parque), 10 abr. 2003 (fl), L.R. Lima \& M. Magenta 296 (SP, SPF, WIS). Cambiju: 15 jan. 1880 (fl), L. Damazio s.n. (RB 82984); 15 jan. 1880 (fl), L. Damazio s.n. (RB 82998). Canela: Passo do Inferno para Canela, 10 fev. 1941 (fl), B. Rambo s.n. (PACA 4831); Lage da Pedra, 18 set. 1971 (fl, fr), J.C. Lindeman s.n. (ICN 8124, PACA 76210); id., 13 maio 1973 (fl), L.R.M. Baptista \& M.L. Porto s.n. (ICN 24311, K); id., 13 maio 1973 (fl, fr), Mariath 11 (ICN); id., 25 abr. 1977 (fl), M. Fleig 411 (ICN); proximidades do hotel Lage de Pedra, fev. 1986 (fl), M. Sobral \& R. Silva 4928 (UEC); 17 set. 1998 (fl), S. Diesel 1559 (NY). Caracol: Caracol para Canela, mar. 1945 (fl), K. Emrich s.n. (PACA 28750). Caxias do Sul: Vila Oliva para Caxias do Sul, 6 jan. 1946 (fl), B. Rambo s.n. (LIL n.v., PACA 31088, W); id., 28 ago. 1949 (fl), B. Rambo s.n. (PACA 43128); Lagoa Azul para Caxias do Sul, 21 jun. 1950 (fl), B. Rambo s.n. (PACA 47176); Vila Oliva para Caxias do Sul, 24 fev. 1954 (fl), B. Rambo s.n. (B, PACA 55050); id., 24 fev. 1954 (fl), B. Rambo s.n. (B, PACA 55051); id., 8 fev. 1955 (fl), B. Rambo s.n. (PACA 56757); id., 13 set. 1975 (fl), M.L. Porto 1558 (ICN); Campus da UCS, 3 out. 1986 (fl), R. Wasum 2049 (HUCS, G, MO); Criúva, Ilhéus, elev. 750 m, 17 set. 1988 (fl), R. Wasum 4448 (HUCS, MBM, MO, WIS, WU); Ana Rech-Faxinal, elev. 700 m, 16 set. 1988 (fl), M.T. Poloni et al. 4416 (G, HUCS, MBM, MO, NY, WIS); id., elev. 700 m, 23 nov. 1989 (fr), R. Wasum et al. 6449 (HUCS, G, MO, NY); Jardim Botânico, elev. 750 m, 18 set. 1992 (fl), R. Wasum \& A. Jasper 8652 (B, HUCS, MO, NY, W); Ana Rech, 12 fev. 2000 (fl), A. Kegler 647 (HUCS, MBM); id., 12 fev. 2000 (fl), A. Kegler 669 (HUCS, NY); Ana Rech-São Nicolau, elev. 780 m, 13 fev. 2000 (fl), L. Scur 456 (HUCS, MBM); Criúva, elev. 780 m, 25 mar. 2000 (fl), L. Scur 691 (HUCS); Santa Lúcia do Piaí, elev. 780 m, 1 abr. 2000 (fl), L. Scur 739 (HUCS, MO). Erechim: Gaurama, elev. 700 m, 10 jan. 1996 (fl), A. Butzke et al. s.n. (HUCS 11671). Esmeralda: 23 set. 1978 (fl), L. Arzivenco 167 (ICN); Estação Ecológica de Aracuri, ago. 1984 (fl), M. Sobral, E. Albuquerque \& M. Paiva 3014 (ICN); 30 ago. 1984 (fl), L.R.M. Baptista s.n. (ICN 62675); Estação Ecológica de Aracuri, ago. 1984 (fl), M. Sobral, E. Albuquerque \& M. Paiva 3030 (HRB, ICN, SP); id., 10 nov. 1984 (fl, fr), S. Miotto 999 (ICN); id., elev. ca. 900 m, 5 out. 1985 (fl, fr), F.A. Silva 595 (ICN); Fazenda da Guabiroba, elev. 850 m, 12 nov. 1987 (fl), R. Wasum et al. 3204 (HUCS, G, MO, NY). Farroupilha: 18 nov. 1957 (fl, fr), O.R. Camargo 2578 (B, PACA). Jaquirana: Fazenda das Cachoeiras, Cachoeira dos Venâncios, 2 mar. 1999 (fl), R.S. Rodrigues \& A. Flores 930 (ICN); id., Cachoeira dos Venâncios, 2 mar. 1999 (fl, fr), R.S. Rodrigues \& A. Flores 932 (ICN). Gramado: Gramado para Canela, 10 jan. 1941 (fl), B. Rambo s.n. (PACA 4990). Palmeira das Missões: campo Boi Preto, elev. 500 m, 29 set. 1906 (fl), A. Bornmüller 729 (M). Passo Fundo: dez. 1955 (fr), P. Frediani s.n. (PACA 57365); 20 out. 1957 (fl, fr), O.R. Camargo 2200 (B). Pelotas: a 7 km do rio Pelotas, 23 out. 1961 (fl), E. Pereira 6440 \& Pabst 6267 (RB). Ronda Alta: a 12 km de Ronda Alta, em direção a Passo Fundo, 14 nov. 1976 (fl), M.L. Porto et al. 2383 (ICN). São Francisco de Paula: 14 jan. 1937 (fl), B. Rambo s.n. (PACA 1815); 14 jan. 1937 (fl), B. Rambo s.n. (PACA 2540); fazenda Englert para São Francisco de Paula, 8 fev. 1941 (fl), B. Rambo s.n. (PACA 4567); id., jan. 1944 (fl), P. Buck s.n. (PACA 11549); id., jan. 1944 (fl), P. Buck s.n. (PACA 11636); 14 fev. 1946 (fl, fr), B. Rambo (K, LIL n.v, PACA 32203.); 18 dez. 1949 (fl), B. Rambo s.n. (PACA 44903); 31 jan. 1950 (fl), B. Rambo s.n. (PACA 45656); 13 mar. 1950 (fl), B. Rambo s.n. (LIL n.v., PACA 46285, W); 9 set. 1952 (fl), B. Rambo 
s.n. (B, PACA 52967); 9 set. 1952 (fl), B. Rambo s.n. (PACA 52969); fazenda Englert, 2 jan. 1955 (fr), B. Rambo s.n. (PACA 56267); Barragem de Blang, 26 set. 1958 (fl), O.R. Camargo 84 (PACA); elev. 900 m, 15 ago. 1965 (fl), A. Sehnem 8454 (HUCS); 26 jan. 1969 (fl), L. Körner \& B. Irgang s.n. (ICN 5727); São Francisco de Paula-Cambará do Sul, próximo ao IBDF, 18 set. 1981 (fl), B. Irgang s.n. (ICN 50462); id., próximo ao IBDF, 18 set. 1981 (fl), B. Irgang s.n. (ICN 50463); Floresta Nacional I, elev. 850 m, 24 set. 1994 (fl), R. Wasum et al. 10239 (B, HUCS, G, MBM, MO, NY, W); centro de britagem, 27 out. 1997 (fl, fr), R.S. Rodrigues 479 (ICN); 5 mar. 1998 (fl), S. Diesel 1252 (NY); Lajeado Grande, junto ao arroio, elev. 800 m, 12 set. 1999 (fl), R. Wasum 122 (B, HUCS, MBM, MO); 17 mar. 2001 (fl), S. Diesel 2424 (MO); Parque das Cachoeiras, elev. 830 m, 21 set. 2002 (fl), R. Wasum 1553 (G, HUCS n.v.); São Francisco de Paula-Cazuza Ferreira, elev. 830 m, 28 out. 2002 (fr), R. Wasum 1588 (G, HUCS n.v.). São Marcos: BR 116, elev. 780 m, 3 set. 1998 (fl), A. Kegler 38 (HUCS, G, MBM, MO). Taquari: Estação Experimental de Pomicultura, 9 nov. 1958 (fl, fr), O.R. Camargo 3365 (PACA 66454). Vacaria: Fazenda da Ronda para Vacaria, 3 jan. 1947 (fl), B. Rambo s.n. (PACA 34765); Hidráulica, 18 fev. 1976 (fl), L. Arzivenco s.n. (ICN 42104); Encanados, 18 dez. 1997 (fl), J. Mauhs s.n. (PACA 85120); id., 18 dez. 1997 (fl), J. Mauhs s.n. (PACA 85121); Encanados, 18 dez. 1997 (fl), R.A. Záchia et al. 2686 (BHCB); estrada para Bom Jesus, elev. 900 m, 6 out. 2000 (fl), R. Wasum et al. 683 (HUCS). Santa Catarina: Bom Retiro: elev. 1.300-1.400 m, 22 dez. 1956 (fl), L.B. Smith 7870 (F). Guarapuava: rio Coitinho, elev. 1.000 m, 15 dez. 1965 (fl), R. Reitz \& R.M. Klein 17657 (NY, P). São Joaquim: 10 jan. 1958 (fl), J. Mattos s.n. (PACA 64216). Urubici: Morro da Igreja, elev. 1.700 m, 16 out. 1993 (fl), D.B. Falkenberg 6280 (FLOR n.v., MBM); id., elev. 1800 m, 16. out. 1993 (fl), D.B. Falkenberg 6294 (FLOR n.v., MBM). Xanxerê: norte de Abelardo, elev. 500-600 m, 19 fev. 1957 (fl), L.B. Smith \& R. Klein 11470 (NY).

Croton myrianthus é uma espécie bastante semelhante a C. erythroxyloides quanto ao hábito e tipo de indumento sendo, muitas vezes, difícil distinguir esses dois táxons, já que em ambos as faces foliares são lepidotas, com indumento formado por tricomas tipicamente lepidotos. Entretanto, C. erythroxyloides possui inflorescências bissexuadas, face adaxial das sépalas das flores pistiladas e estiletes lepidotos, ao passo que em C. myrianthus as inflorescências são unissexuadas, a face adaxial das sépalas das flores pistiladas é tomentosa, coberta por tricomas estrelados, e os estiletes são completamente glabros. A forma e tamanho das folhas são caracteres bastante variáveis nos dois táxons e essa variação é uma característica comum nas diversas espécies de Croton, porém em geral, C. myrianthus possui as folhas mais estreitas e mais longas quando comparadas às de C. erythroxyloides.

Croton myrianthus foi descrita por Mueller (1865) na seção Decarinium, no grupo de espécies com estiletes apenas uma vez bífidos. Nesse grupo foram descritas, além de C. myrianthus, mais três espécies - C. minarum Müll. Arg., C. minutiflorus Müll. Arg. e C. boissieri Müll. Arg. - as duas primeiras, espécies do Brasil e a última, uma espécie peruana. Segundo o autor (Mueller 1865), as espécies brasileiras podem ser distinguidas entre si, principalmente, pela presença ou não de indumento na face adaxial das folhas e, quando presente, pelo tipo de tricoma que compõe tal indumento. Posteriormente, C. minarum foi sinonimizada em C. ceanothifolius (Mueller 1873) e C. minutiflorus em C. gaudichaudii e, logo depois, em $C$. uruguayensis. Infelizmente, não foram vistas, nos herbários visitados, coleções de $C$. boissieri, entretanto esse táxon parece não pertencer à seção Lamprocroton, já que possui flores estaminadas com 20 estames, sendo 16 o limite máximo de estames para a seção Lamprocroton e, portanto não foi tratada no presente trabalho.
Em praticamente todos os espécimes analisados além das inflorescências serem unissexuadas há apenas um tipo de inflorescência na planta, ou seja, existem apenas flores estaminadas ou pistiladas na planta toda, o que poderia indicar uma dioicia da espécie. No entanto, por conta de alguns materiais possuírem inflorescências bissexuadas preferiu-se interpretar esse fato como decorrente de uma provável dicogamia, caso em que um mesmo indivíduo produziria flores estaminadas em época distinta da produção de flores pistiladas. Um estudo mais detalhado de biologia floral é necessário para que seja esclarecido se na espécie prevalece ou não a dioicia.

Allem (1978) sinonimizou C. myrianthus em C. tenuissimus, alegando que a presença de indumento na face adaxial das folhas era um caráter regional, isto é, nos indivíduos provenientes do sudoeste do Rio Grande do Sul a face adaxial das folhas é glabra e, naqueles provenientes do nordeste, indumentada, porém preferiu-se aqui considerar essas duas espécies como entidades distintas. No entanto, às vezes, os tricomas da face adaxial das folhas de C. myrianthus caem e algumas das folhas podem apresentar a face adaxial completamente glabra ou com alguns tricomas esparsos e, nesses casos, $C$. myrianthus pode assemelhar-se bastante a $C$. uruguayensis (nome correto de C. tenuissimus). Smith et al. (1988) propuseram, de modo não formal, o rebaixamento de $C$. myrianthus Müll. Arg. a uma variedade de C. pallidulus Baill., sem que dessem nenhuma explicação do motivo dessa mudança de categoria taxonômica. Aqui, isso não é aceito, pois essas duas espécies possuem caracteres suficientemente consistentes para serem mantidas como táxons distintos, tais como tipo de tricomas das duas faces foliares, tipo de inflorescência, ambiente em que ocorrem, entre outros

17. Croton pallidulus Baill., Adansonia 4: 296. 1864. Tipo: citado abaixo, sob a var. pallidulus.

Subarbustos a arbustos, 0,3-2,5 m altura, monóicos; caule lepidoto, tricomas estrelado-lepidotos a dentado-lepidotos, raios laterais parcialmente unidos (50-70\% do comprimento total), raio porrecto presente, creme, dourados, acastanhados a creme-cinéreos, sésseis. Folhas fortemente discolores, inteiras, cartáceas, elípticas a ovais, ápice agudo, acuminado a levemente arredondado, base aguda a arredondada, margem inteira, lâmina 1,2-4,5 $(-8,0)$ cm comprimento, 0,5-1,5(-4,0) cm largura, nervação broquidódroma, impressa na face adaxial, saliente na abaxial, face adaxial glabra a tomentosa, tricomas estrelados, raio porrecto presente, creme a dourados, sésseis a curto-estipitados, face abaxial lepidota, tricomas pseudo-lepidotos, raios laterais parcialmente unidos (ca. $30 \%$ do comprimento total), raio porrecto presente, creme, dourados a creme-cinéreos, sésseis a curto-estipitados; pecíolos 1,5-8,0 mm comprimento Inflorescências racemos bissexuados, 1,5-5,5 cm comprimento, lepidotos, tricomas estrelado-lepidotos a dentado-lepidotos, raios laterais parcialmente unidos (50-70\% do comprimento total), raio porrecto presente, creme, dourados a creme-cinéreos, sésseis; brácteas inteiras, persistentes, 1,5-3,0 mm comprimento, lanceoladas a estreitamente triangulares, ápice agudo, face abaxial lepidota, tricomas estrelado-lepidotos a dentado-lepidotos, raios laterais parcialmente unidos $(50-70 \%$ do comprimento total), raio porrecto presente, creme, dourados a creme-cinéreos, sésseis, face adaxial glabra. Flores estaminadas alvas, creme, ocráceas, amarelo-pálidas a amarelo-esverdeadas, 1,5-3,0 mm comprimento; pedicelos 1,5-3,0 mm comprimento; sépalas 1,5-2,5 mm comprimento, cartáceas, ovais, ápice agudo, face abaxial lepidota, tricomas estrelado-lepidotos a dentado-lepidotos, raios laterais parcialmente unidos (50-70\% do comprimento total), raio porrecto presente, creme a dourados, sésseis, face adaxial glabra; pétalas ca. 2,0 $\mathrm{mm}$ comprimento, cartáceas, estreitamente oblongas a estreitamente elípticas, ápice agudo a arredondado, ápice e metade ou terço distal da margem ciliados, tricomas simples, 
alvos, metade proximal da margem vilosa, tricomas simples, alvos, face abaxial glabra a, raramente, lepidota, tricomas lepidoto-típicos, raios laterais parcialmente unidos (ca. $90 \%$ do comprimento total), raio porrecto ausente, creme a dourados, sésseis, região proximal da face adaxial vilosa, tricomas simples, alvos; estames 12-15, filetes ca. 2,0 mm comprimento, filiformes, glabros, anteras $0,8-1,0 \mathrm{~mm}$ comprimento, conectivos glabros; receptáculo tomentoso, tricomas simples, alvos; disco 5-lobado. Flores pistiladas creme, alvascentas, esverdeadas a amarelo-esverdeadas, 3,0-5,0 $\mathrm{mm}$ comprimento; pedicelos 1,5-2,5 mm comprimento; sépalas desiguais, duas menores, 2,5-3,0 mm comprimento, três maiores, 3,5-4,0 mm comprimento, coriáceas, ovais, ápice agudo, face abaxial lepidota, tricomas estrelado-lepidotos a dentado-lepidotos, raios laterais parcialmente unidos (50-70\% do comprimento total), raio porrecto ausente, creme, dourados a creme-cinéreos, sésseis, metade distal da face adaxial tomentosa, tricomas estrelados, raio porrecto presente, creme a alvos, sésseis; pétalas presentes, reduzidas; disco 5-lobado; ovário lepidoto, tricomas estrelado-lepidotos a dentado-lepidotos, raios laterais parcialmente unidos (50-70\% do comprimento total), raio porrecto presente, creme a dourados, sésseis e, tricomas estrelados, raio porrecto presente, dourados, estipitados; estiletes bífidos, ramificados desde a base, glabros; regiões estigmáticas 6, glabras. Frutos ca. 5,0 mm comprimento, ca. 6,0 mm largura; sementes ca. 3,0 mm comprimento, ca. 2,0 mm largura, elipsóides, testa castanho-clara a castanho-alaranjada, lisa a levemente rugosa.

Alguns indivíduos de $C$. pallidulus possuem a face adaxial das folhas totalmente glabras ou pubescentes apenas na região da nervura mediana. Essa característica parece ser suficientemente consistente para ser utilizada na proposta de uma nova variedade $-C$. pallidulus var. glabrus L.R. Lima - distinta da variedade típica especialmente por conta da ausência, ou quase ausência de indumento na face adaxial das folhas.

\section{Chave de identificação para as variedades de C. pallidulus}

1. Face adaxial das folhas tomentosa....

17.2. C. pallidulus var. pallidulus

2. Face adaxial das folhas glabra ou raramente pubescente apenas na nervura principal

17.1. C. pallidulus var. glabrus

17.1. Croton pallidulus var. glabrus L.R. Lima, var. nov. Tipo: Paraná, Curitiba, 'Parque Municipal do Iguaçu', 26 jan. 2004 (fl), L.R. Lima, M.A. Farinaccio \& J.M. Silva 325 (holótipo, SPF; isótipos, SP, WIS).

Figuras $9 \mathrm{j}-\mathrm{k}$; $17 \mathrm{~d}$.

A var. pallidulus, caeterius simillima, foliis supra glabris raro ad nervo médio strigosis diversa.

Face adaxial das folhas glabra a, raramente, estrigosa apenas na nervura primária, tricomas estrelados, raio porrecto presente, alvos a creme, sésseis; pétalas das flores estaminadas estreitamente elípticas. Essa variedade distingue-se da variedade típica por apresentar a face adaxial da folha glabra a, raramente, estrigosa apenas na nervura primária.

Distribuição geográfica e hábitats: Ocorre somente nos estados de São Paulo, Paraná e Santa Catarina, preferencialmente, em áreas com baixa drenagem como brejos e margem de rios, em locais com solo arenoso e com altitudes modestas. Também foi coletada em borda de mata ciliar.

Fenologia: Foram observados materiais com flores de agosto a janeiro e em junho. Frutos foram vistos em janeiro, agosto, setembro e dezembro.

Material examinado: Brasil: Paraná: Curitiba: elev. 900 m, 13 set. 1915 (fl), P. Dusén 17188 (G, MO); 29 set. 1948 (fl), G. Tessmann s.n. (MBM 265925); bairro do Atuba, estrada federal, set. 1959 (fl, fr), R. Lanje s.n. (MBM 195573, RB 125793); Boqueirão, 28 jan. 1975 (fl), L.F. Ferreira 194 (MBM, MO); Parque Regional do Iguaçu, 18 ago. 1979 (fl), A. Meijer s.n. (MBM 208210); id., jan. 1985 (fl, fr), A. Meijer 32 (MBM); Parque Náutico, 16 set. 1985 (fl, fr), J. Cordeiro 167 (MBM); Parque Municipal do Iguaçu, 26 jan. 2004 (f), L.R. Lima, M.A. Farinaccio \& J.M. Silva 325 (SP, SPF, WIS); id., 26 jan. 2004 (fl), L.R. Lima, M.A. Farinaccio \& J.M. Silva 326 (SP, SPF). Palmeira: s.d. (fl), L.T. Dombrowski \& P. Scherer Neto 868 (MBM). Piraquara: rio Palmital, 30 jun. 1977 (fl), N. Imaguire 5020 (MBM); próximo ao rio Iraí, 19 ago. 1992 (fl, fr), S.R. Ziller 370 (MBM). Ponta Grossa: Parque Vila Velha, 21 out. 1989 (fl), A.C. Cervi et al. 2896 (MBM). São José dos Pinhais: Colônia Roseira, 30 out. 1967 (fl), G. Hatschbach 17638 (MBM); Boneca do Iguaçu, 24 out. 1979 (fl), P.I. Oliveira 128 (MBM, MO). São Mateus do Sul: Fazenda do Durgo, 21 set. 1986 (fl), R.M. Britez 826, S.M. Silva 700 \& W.S. Souza 267 (MBM). Santa Catarina: Água Doce: rio Chapecó, $12 \mathrm{~km}$ ao sul de Horizonte (Paraná), ca. $26^{\circ} 41^{\prime} \mathrm{S}$ e $51^{\circ} 37^{\prime} \mathrm{W}$, elev. 1.000-1.100 m, 4 dez. 1964 (fl, fr), L.B. Smith \& R.M. Klein 13563 (SP). Lages: 1935 (fl), A. Bruxel s.n. (PACA 6821). Matos Costa: elev. 1.000 m, 27 out. 1962 (fl), R. Reitz \& R.M. Klein 13737 (B). Urubici: Mundo Novo, elev. ca. 1500 m, 12. nov. 1964 (fl), J. Mattos 12120 (SP). São Paulo: Campos do Jordão: Parque Estadual de Campos do Jordão, trilha do rio Sapucaí, 29 out. 2003 (fl), L.R. Lima \& P.M.S. Rosa 319 (SPF).

17.2. Croton pallidulus Baill. var. pallidulus. Tipo: [Brasil], 'Prov. de Saint.Paul', [1816-1821], Saint-Hilaire C2-1473 (holótipo, P!; isótipo, F!).

Croton ceanothifolius sensu Smith \& Downs, Sellowia 11: 184, pl. 12, Figuras e-h. 1959, non Baill.

Figuras 9g-j; 17e.

Nome popular: "velame-do-campo" (L. Krieger 1014)

Face adaxial das folhas tomentosa, tricomas estrelados, raio porrecto presente, alvos a creme, sésseis a curto-estipitados; pétalas das flores estaminadas estreitamente oblongas.

Distribuição geográfica e hábitats: Ocorre, principalmente, na região Sul do Brasil, nos estados do Paraná, Santa Catarina e Rio Grande do Sul. É bastante freqüente no Paraná onde ocorre em diversos municípios. Em São Paulo, foi coletada apenas nos municípios de Campos do Jordão, de Itararé e da capital, nos dois últimos, uma única vez. Ocorre também em alguns municípios de Minas Gerais, em geral, naqueles próximos aos limites com o estado de São Paulo. Há somente uma coleção proveniente do Rio de Janeiro, contudo a ausência de dados na etiqueta da exsicata impossibilita saber em que município desse estado a planta teria sido coletada. Pode ser encontrada nos mais diversos tipos de ambientes como afloramentos rochosos, campo arenoso, cerrado pedregoso, campo úmido, campo sujo, capão de mata, capoeira, campo com palmeiras do gênero Butia Becc. ("butiazal") e em borda de mata de galeria. Trata-se também de uma planta invasora, freqüente em regiões de campo degradado. Foi coletada em localidades cujas altitudes variam dos 700 aos $2.000 \mathrm{~m}$. No município de Campos do Jordão (SP) é comum nas regiões de campo junto às Matas de Araucária, na borda de capão e em regiões de capoeira, a cerca de $1.500 \mathrm{~m}$ de altura.

Fenologia: Floresce durante o ano inteiro. Não foram observados materiais com frutos nos meses de março e julho.

Material examinado: Minas Gerais: São Roque de Minas: São José do Barreiro, estrada para Itajubá, 20 abr. 1939 (fl, fr), M. Kuhlmann \& A. Gehrt s.n. (NY s.n., SP 40236). Belo Horizonte: Serra Rola Moça, 4 maio 1960 (fl), M. Magalhães 17680 (NY). Caeté: União, 26 nov. 1942 (fl), M. Magalhães 2727 (IAN). Delfim Moreira: São Francisco dos Campos, alto do Morro do Cabrito, 7 jun. 1950 (fl, fr), M. Kuhlmann 2442 (SP); margem da rodovia para Piquete, 20 jul. 1995 (fl), G.F. Arbocz 1598 (SP, SPF). Itajubá: divi- 
sa com o estado de São Paulo, na rodovia Campos do Jordão-Itajubá, via Fazenda da Guarda, 26 ago. 1967 (fl), J. Mattos \& N. Mattos 15041 (SP). Paraná: Serra do Mar, 23 nov. 1972 (fl), L.T. Dombrowski \& Y.S.Kuniyoshi 4306 (P). Almirante Tamandaré: 23 set. 1976 (fl, fr), R. Kummrow 1140 (MBM). Calmão: 14 mar. 1910 (fl), P. Dusén 9401 (MO); 20 mar. 1910 (fl), P. Dusén 9372 (MO). Campo Largo: alto da Serra de São Luiz do Purunã, 23 fev. 1960 (fl, fr), H. Moreira Filho 187 (MBM). Castro: Carambeí, rio São João, 2 jun. 1963 (fl, fr), G. Hatschbach 10090 (MBM); id., ca. 24 30' S e 50²' W, elev. 950 m, 15 jan. 1965 (fl), L.B. Smith, R.M. Klein \& G. Hatschbach 14528 (B, F); id., rio São João Castro, elev. 950 m, 17 dez. 1965 (fl), R. Reitz \& R.M. Klein 17850 (B). Colombo: estrada para Colombo, 23 set. 1974 (fl, fr), L.F. Ferreira 40 (MBM). Curitiba: $1 \mathrm{~km}$ a leste de Curitiba, 8 set. 1966 (fl), J.C. Lindeman \& J.H. Haas 2421 (K, W, WIS); $6 \mathrm{~km}$ a leste de Curitiba, 27 set. 1966 (fl, fr), J.C. Lindeman \& J.H. Haas 2534 (K, NY, WIS); Vila Parolim, 26 fev. 1970 (fl), G. Hatschbach 23919 (MBM); Barigui, 1 fev. 1971 (fl), G. Hatschbach 26228 (G, MBM, MO); Umbará, rio Iguaçu, 31 set. 1972 (fl), G Hatschbach 30385 (MBM, MO.); Boqueirão, 23 ago. 1982 (fl), P.I. Oliveira 648 (MBM); bosque Tapajós, 6 out. 1986 (fl), E.F. Paciornik 298 (MBM); Tolstoi, 11 set. 1987 (fl, fr), N. Imaguire 8536 (MBM). General Carneiro: cabeceira do rio Iratim, 11 fev. 1966 (fl), G. Hatschbach, H. Haas \& J. Lindeman 13717 (K, MBM, NY, W, WIS); id., 10 out. 1966, (fl), G. Hatschbach 14585 (F, MBM); id., 18 out. 1966 (fl), G. Hatschbach 14989 (MBM); id, 18 out. 1966 (fl), G. Hatschbach 14989-A (MBM); id., 18 out. 1966 (fl), G. Hatschbach 14989-B (MBM, P). Guarapuava: entre rio Coutinho e Cavernoso, 21 out. 1960 (fl), G. Hatschbach 7400 (MBM, MO); fazenda Campo Real, elev. 1000 m, 16 dez. 1965 (fl), R. Reitz \& R.M. Klein 17794 (B). Laranjeiras do Sul: 1 maio 1957 (fl), G. Hatschbach 3963 (MBM). Mandirituba: Santo Amaro, Rio de Vargem, 1 out. 1986 (fl), R. Kummrow \& J. Cordeiro 2785 (MBM, PACA); arredores da cidade, 23 ago. 1988 (fl), R. Kummrow, G. Pringle \& O.S. Ribas 3055 (MBM). Palmas: Horizonte, elev. 1200 m, 18 set. 2001 (fl), G.Hatschbach, R. Goldenberg \& J.M. Silva 72370 (MBM). Palmeira: 15 jul. 1938 (fl), J.E. Rombouts s.n. (IAC 2594, SP 40755); fazenda Santa Rita, 6 maio 1980 (fl), L.T. Dombrowski 10399 (MBM); id., 4 jul. 1980 (fl), L.T. Dombrowski 11416 \& P. Scherer 1875 (MBM); id., 22 jul. 1980 (fl), L.T. Dombrowski 11440 (MBM); id., 17 nov. 1980 (fl), L.T. Dombrowski 11836 (MBM); Colônia Primavera, fazenda Cambiju, 1 ago. 1999 (fl), S.R. Ziller 1842 (MBM, W). Piên: 1 set. 1986 (fl), R. Kummrow \& J. Cordeiro 2788 (MBM); 1 set. 1986 (fl, fr), R. Kummrow \& J. Cordeiro 2789 (MBM, SPF). Pinhão: rio Jordão, Salto da Tia Chica, 24 fev. 1996 (fl), G. Hatschbach, S.R. Ziller \& J.M. Silva 64536 (MBM, W). Piquete: estrada velha para São Francisco dos Campos, 20 jul. 1995 (fl), G.F. Arbocz 1616 (SP, SPF). Piraquara: Nova Tirol, 20 ago. 1976 (fl), G. Hatschbach 38846 (MBM); 7 jul. 1977 (fl), G. Hatschbach 40001 (MBM, UEC). Ponta Grossa: arredores da cidade, 7 jan. 1944 (fl), L. Krieger 1014 (SP); Vila Velha, fazenda Lagoa Dourada, $21 \mathrm{~km}$ a sudeste de Ponta Grossa, elev. 830 m, 7 fev. 1948 (fl), G. Tessmann s.n. (MBM 263840); id., 14 jan. 1964 (fl), E. Pereira 8291 (RB); 18 dez. 1971 (fl), L. Krieger 11245 (RB); id., nov. 1964 (fl), L.T. Dombrowski 891, Y. Saito 681 \& M.L. Pereira 274 (MBM); Vila Velha, $25^{\circ} 13^{\prime}$ S e $50^{\circ} 2^{\prime}$ W, elev. 890-920 m, 14 jan 1965 (fl, fr), L.B. Smith, R.M. Klein \& G. Hatschbach 14451 (MO, WIS); Parque Vila Velha, 28 jun. 1975 (fl), A. Dziewa 38 (MBM, MO); noroeste de Ponta Grossa, elev. ca. $150 \mathrm{~m}, 19$ set. 1976 (fl, fr), P.H. Davis \& G.J. Shepherd 61016 (UEC); Rodovia do Café, Curitiba-Ponta Grossa, $9 \mathrm{~km}$ a leste de Vila Velha, elev. 870 m, 11 out. 1977 (fl), E. Forero 3753 (MBM); estação de ônibus de Ponta Grossa, ca. $25^{\circ} 10^{\prime} \mathrm{S}$ e $50^{\circ} 10^{\prime} \mathrm{W}$, elev. ca. $900 \mathrm{~m}$, 15 nov. 1977 (fl), L.R. Landrum 2511 (MBM); rio Barrozinho, 6 mar. 1982 (fl), R. Kummrow, J.G. Stutts \& S. Graham 1894 (MBM); Vila
Velha, 28 out. 1983 (fl), A.C. Cervi et al. 2230 (NY, UPCB n.v.); id., Parque Nacional de Vila Velha, $25^{\circ} 10^{\prime} \mathrm{S}$ e $50^{\circ} \mathrm{W}$, elev. ca. $800 \mathrm{~m}$, 15 ago. 1990 (fl, fr), I. Rauscher 43 (W); Prudentópolis: Relógio, 28 jan. 1968 (fl, fr), G. Hatschbach 18298 (MBB, MO). São José dos Pinhais: Rincão, 9 fev. 1947 (fl), G. Hatschbach 623 (MBM, PACA); Lagoinha, 2 ago. 1952 (fl), G. Hatschbach 2810 (MBM); Rio Pequeno, 10 set. 1967 (fl, fr), N. Imaguire 179 (MBM); Colônia Murici, nov. 1966 (fl, fr), L.T. Dombrowski 1936 \& Y.S. Kuniyoshi 1671 (MBM); Contenda, 22 jun. 1971 (fl), G. Hatschbach 26815 (MBM, MO); Colônia Murici, 12 nov. 1979 (fl), P.I. Oliveira 152 (MBM, MO); Contenda, 17 set. 1981 (fl), R. Kummrow 1570 (MBM, MO); próximo a Curitiba, na rodovia BR 376, elev. $850 \mathrm{~m}, 10 \mathrm{dez}$. 1987 (fl), S. Tsugaru, Y. Fugimoto \& T. Tariki B-2361 (MO, NY); APA do Arujá, 23 maio 1997 (fl), L. Rocha \& D. Zakrzewski s.n. (MBM 226622); Reservatório da Sanepar, estrada São José dos Pinhais-Guaratuba, 26 jan. 2004 (fl, fr), L.R. Lima, M.A. Farinaccio \& J.M. Silva 327 (SP, SPF, WIS). Quatro Barras: nov. 1979 (fl), L.T. Dombrowski 13546 (MBM). Tijucas do Sul: Campinas, 46 km ao sul de Curitiba, 14 fev. 1978 (fl, fr), A. Krapovickas \& C.L. Cristóbal 33660 (CTES n.v., MBM, MO). Rio de Janeiro: s.d. (fl, fr), M. Kuhlmann s.n. (RB 80706). Rio Grande do Sul: Barracão: Parque Estadual Espigão Alto, 24 out. 1985 (fl, fr), J.R. Stehmann 723 (ICN). Campo Bonito: BR 101, km 6, ca. de $8 \mathrm{~km}$ a sudoeste de Torres, 10 fev. 1983 (fl, fr), A. Krapovickas \& C.L. Cristóbal 38470 (CTES n.v., MBM). Itapoã: Granja Neugebauer para Itapoã, 11 out. 1950 (fl), B. Rambo s.n. (PACA 48970). Lagoa dos Quadros: Lagoa dos Quadros para Torres, 21 fev. 1950 (fl), B. Rambo s.n. (PACA 45985). Morro Grande: Morro Grande para Osório, 10 fev. 1952 (fr), B. Rambo s.n. (PACA 51763). Passo do Socorro: Passo do Socorro para Vacaria, 3 dez. 1955 (fl), B. Rambo s.n. (B, PACA 51550). São Brás: entre São Brás e Torres, 9 nov. 1972 (fl), M.H. Homrich s.n. (ICN 20786). Torres: 25 set. 1969 (fl), J. Vasconcellos, L. Baptista \& B. Irgang s.n. (ICN 7041); 25 set. 1969 (fl), J. Favalli, B. Irgang \& L. Baptista s.n. (ICN 7060); 2 out. 1975 (fl, fr), A. Allem s.n. (ICN 29447); 28 mar. 1998 (fl), R.S. Rodrigues 468 (ICN). Santa Catarina: Água Doce: Campos de Palmas, $15-19 \mathrm{~km}$ ao sul de Horizonte (Paraná), ca. $26^{\circ} 44^{\prime} \mathrm{S}$ e $51^{\circ} 37^{\prime} \mathrm{W}$, elev. 1.100-1.200 m, 4-5 dez. 1964 (fl, fr), L.B. Smith \& R.M. Klein 13606 (K). Bom Retiro: elev. 900 m, 29 set. 1986 (fl), D.B. Falkenberg 3483 (ICN); id., 29 set. 1986 (fl), D.B. Falkenberg 3485 (ICN). Caçador: 8 km ao norte de Caçador, elev. 950-1.100 m, 21 dez. 1956 (fl), L.B. Smith \& R. Reitz 8959 (F, P); id., elev. 900-1.100 m, 7 fev. 1957 (fl), L.B. Smith \& R. Klein 10949 (MO); fazenda Carneiros, elev. 1100 m, 16 set. 1962 (fl), R.M. Klein 3092 (B, G, K); id., elev. 1100 m, 16 set. 1962 (fl), R.M. Klein 3094 (M). Canoinhas: Horto Florestal do I.N.P., elev. 750 m, 15 set. 1962 (fl), R.M. Klein 3018 (K). Curitibanos: elev. 850 m, 8 set. 1957 (fl), R. Reitz \& R.M. Klein 4906 (NY). Lages: 10 jan. 1951 (fl), B. Rambo s.n. (HUCS 5655 n.v., PACA 49522); ao longo da Estrada de Rodagem Federal, ao sul de Lages, elev. ca. 900 m, 3 dez. 1956 (fl), L.B. Smith \& R.M. Klein 8123 (SP); 25 dez. 1956 (fr), J. Mattos s.n. (PACA 61066); Pedra Branca, 10 nov. 1964 (fl), J. Mattos 11978 (SP, UEC); id., 10 nov. 1964 (fl), J. Mattos s.n. (UEC 4685); $30 \mathrm{~km}$ após a ponte sobre o rio Pelotas, 21 nov. 1997 (fl), R.S. Rodrigues 398 (ICN); em direção a São José do Cerrito, $13 \mathrm{~km}$ após o trevo, BR 282, 21 nov. 1997 (fl, fr), R.S. Rodrigues 400 (ICN); id., 21 nov. 1997 (fl, fr), R.S. Rodrigues 401 (ICN); id., 21 km após o trevo, BR 282, 21 nov. 1997 (fl), R.S. Rodrigues 407 (ICN); $23 \mathrm{~km}$ do trevo para Lages, BR 282, 21 nov. 1997 (fl), R.S. Rodrigues 410 (ICN); Capão Alto, BR 116, km 262, 27 nov. 1997 (fl), R.S. Rodrigues \& A. Flores 452 (ICN). Matos Costa: rodovia SC 114, 23 fev. 1972 (fl), G. Hatschbach \& T. Koyama 29184 (MBM, MO). Porto União: elev. ca. 750 m, 14 mar. 1957 (fl), L.B. Smith \& R. Klein 12153 (M); elev. 750 m, 6 jan. 1962 (fl, fr), R. Reitz \& R.M. Klein 
11654 (NY); Calmon, elev. 900 m, 23 fev. 1962 (fl), R. Reitz \& R..M. Klein 12326 (MBM); id., elev. 900 m, 23 fev. 1962 (fl, fr), R. Reitz \& R.M. Klein 12329 (K, M); 22 abr. 1962 (fl), R. Reitz \& R.M. Klein 12754 (NY, PACA); elev. 750 m, 16 set. 1962 (fl), R.M.Klein 3052 (MBM); 26 out. 1962 (fr), R. Reitz \& R.M. Klein 13630 (B). São José: Serra da Boa Vista, elev. 1.000 m, 23 mar. 1961 (fl), R. Reitz \& R.M. Klein 10791 (B, G). Sombrio: 20 ago. 1945 (fl), R. Reitz 1995 (MBM); 7 fev. 1946 (fl), B. Rambo s.n. (PACA 31784); Praia das Gaivotas, 15 abr. 1994 (fl), G. Hatschbach, M. Hatschbach \& E. Barbosa 60597 (MBM). São Paulo: Bom Sucesso do Itararé: fazenda São Nicolau, 24 16' S e 49 9' W, elev. 1.200 m, 10 set. 1993 (fl), V.C. Souza et al. 4042 (BHCB, ESA, MBM, RB, SP); estrada de terra Bom Sucesso do Itararé-Itapirapuã Paulista, 14 fev. 2004 (fl), M.B.R. Caruzo et al. 30 (SP, SPF, WIS); id., 14 fev. 2004 (fl), M.B.R. Caruzo et al. 31 (SP, SPF, WIS). Campos do Jordão: Fazenda da Guarda, 15 dez. 1966 (fl), J. Mattos \& N. Mattos 14357 (SP); Parque Estadual de Campos do Jordão, Pedra Chorona, elev. 2.000 m, 25 out. 1974 (fl), P. Carauta 1742 (RB); id., Pedra Chorona, 25 out. 1974 (fl), J. Mattos 15903 (SP); Reserva do Instituto Florestal, estrada para Paiol, 30 set. 1976 (fl), P.H. Davis et al. 3088 (UEC); id., $22^{\circ} 45^{\prime} \mathrm{S}$ e $45^{\circ} 30^{\prime} \mathrm{W}$, elev. ca. $1.700 \mathrm{~m}, 28$ maio 1983 (fl), A. Amaral-Jr. et al. 5-28583 (SP); id., 23 mar. 1984 (fl), M.J. Robim \& J.P.M. Carvalho 8433 (SP, SPSF n.v.); estrada entre a Reserva do Instituto Florestal e São José dos Alpes, elev. 1.700 m, 22 set. 1984 (fl), L.S. Kinoshita \& N. Taroda 16484 (UEC); Parque Estadual de Campos do Jordão, Instituto Florestal, trilha da cachoeira, 8 out. 1984 (fl), M.J. Robim \& J.P.M. Carvalho s.n. (SP 237470, SPSF 8736 n.v.); id., Instituto Florestal, região do Ribeirão, 15 mar. 1988 (fl), M.J. Robim 564 (SP, SPSF n.v.); id., trilha do rio Sapucaí, 27 maio 1991 (fl, fr), S. Xavier \& E. Caetano 42 (MBM, SP); id., 16 mar. 1992 (fl), S. Xavier \& E. Caetano 173 (SP, SPSF n.v.); id., trilha do rio Sapucaí, 7 jun. 1992 (fl, fr), E. Martins et al. 26467 (UEC); id., 7 jun. 1992 (fl), I. Koch et al. 26346 (UEC); id., 7 jun. 1992 (fl), J.Y. Tamashiro et al. 26649 (UEC); id., trilha do rio Sapucaí, 15 out. 1992 (fl), S. Xavier et al. 308 (SP, SPSF n.v.); id., trilha do rio Sapucaí, 15 out. 1992 (fl), S. Xavier et al. 309 (SP, SPSF n.v.); Reserva do Instituto Florestal, $22^{\circ} 39^{\prime} 15,2^{\prime \prime} \mathrm{S}$ e 45 $27^{\circ}$ 1” W, 23 set. 1993 (fl), K.D. Barreto, G.D. Fernandes \& F.X. Vitti 1274 (ESA, SP); Parque Estadual de Campos do Jordão, trilha do rio Sapucaí, ca. $22^{\circ} 41^{\prime} \mathrm{S}$ e $45^{\circ} 28^{\prime}$ W, elev. ca. 1.500 m, 5 dez. 2000 (fl), P. Fiaschi et al. 495 (SPF); id., 22 $2^{\circ} 41^{\prime} 20^{\prime \prime} \mathrm{S}$ e $45^{\circ} 28^{\prime} 60^{\prime \prime} \mathrm{W}$, elev. ca. $1.620 \mathrm{~m}, 27 \mathrm{fev}$. 2002 (fl, fr), I. Cordeiro et al. 2772 (SP, SPF, WIS); id., 27 fev. 2002 (fl), I. Cordeiro et al. 2773 (SP, SPF, WIS); id., trilha da cachoeira, 25 out. 2004 (fl), M.B.R. Caruzo \& S.E. Martins 68 (SP, SPF, WIS); id., trilha do rio Sapucaí, 25 out. 2004 (fl), M.B.R. Caruzo \& S.E. Martins 70 (SP, SPF, WIS). Franco da Rocha: 3 out. 1945 (fl), W. Hoehne s.n. (SP 48514). São Paulo: Belém, 3 out. 1945 (fl, fr), F.C. Hoehne s.n. (SPF 13289).

A observação de indivíduos bastante semelhantes entre si quanto à morfologia, diferindo apenas pela presença ou não de indumento na face adaxial das folhas, ocorrendo em populações distintas, mas em áreas geográficas próximas e no mesmo tipo de ambiente, foram os fatores que levaram à proposição de duas variedades em C. pallidulus. Apesar de, atualmente, o modelo de especiação mais aceito ser a especiação geográfica (Mayr 1942), no qual a alopatria é, provavelmente, a única "regra da especiação" amplamente aceita (Coyne \& Orr 1989), Maynard Smith (1966) demonstrou a viabilidade da especiação simpátrida, na qual polimorfismos estáveis teriam chances de se desenvolver em ambientes heterogêneos como uma etapa crucial na especiação simpátrida. Assim, a decisão sobre que categoria taxonômica adotar para as duas entidades supracitadas, uma com a face adaxial das folhas indumentada e a outra com a face adaxial das folhas glabra, não foi tomada facilmente, já que poderiam ser consideradas não duas variedades, mas sim duas espécies distintas que teriam surgido por meio de especiação simpátrida. Entretanto, a similaridade acentuada entre os indivíduos e ambiente em que ocorrem foram os principais fatores que levaram à proposição de duas variedades e não de duas espécies. Efetivamente, não existe um critério único para definir táxons e o nível no qual alguém os reconhece é apenas convencional (Stevens 1998). Entretanto, segundo Henderson (2005), a delimitação de espécies em monografias e revisões deveria empregar uma metodologia explícita, quantitativa e passível de repetibilidade, além obedecer ao conceito de espécie utilizado; esta hipótese (isto é, a espécie) deveria ser proposta e testada ao mesmo tempo.

O reconhecimento de variedades em $C$. pallidulus não é novidade. Smith et al. (1988) propuseram duas variedades para C. pallidulus baseadas, principalmente, na forma das folhas e no indumento da face adaxial desse órgão. Segundo esses autores (Smith et al. 1988), C. pallidulus var. pallidulus, caracteriza-se por possuir folhas elípticas até oblongo-ovais, muitas vezes mais alargadas próximo à base e com a face adaxial coberta por tricomas estrelados. Já a outra variedade, C. pallidulus var. myrianthus, possui folhas mais estreitas, atenuadas e freqüentemente, mais largas no centro, com face adaxial, em geral, glabra. Entretanto, essa última variedade não é aceita aqui sendo C. pallidulus var. myrianthus (Müll. Arg.) L.B. Smith \& S.F. Smith tratada como um sinônimo de C. myrianthus. Apesar da maioria dos indivíduos ser passível de uma identificação correta, apenas observando-se a face adaxial das folhas, na categoria de variedade, em alguns casos, essa identificação pode ser problemática. Isso se dá diante de algumas coleções em que a maioria das folhas tem a face adaxial das folhas glabras, porém uma ou outra folha apresenta tricomas esparsos nessa região, como por exemplo em Dombrowski 868 e Bruxel s.n. (PACA 6821). Nesses casos, preferiu-se atribuir tais materiais a $C$. pallidulus var. glabrus já que a densidade de tricomas é relativamente baixa quando comparada à de $C$. pallidulus var. pallidulus.

Croton pallidulus é extremamente semelhante a C. ceanothifolius quanto ao hábito, forma e tamanho das folhas, tipo de nervação e inflorescência, porém enquanto na primeira a face adaxial das folhas é completamente glabra ou com indumento formado por tricomas estrelados, na segunda essa região da planta é sempre coberta por tricomas simples. Tal característica pode ser utilizada, de maneira eficaz, na distinção entre as duas espécies. A distribuição geográfica também fornece subsídios para o reconhecimento dessas duas espécies, pois enquanto $C$. ceanothifolius é endêmica do estado de Minas Gerais, principalmente dos municípios de Ouro Branco e Ouro Preto, a distribuição de $C$. pallidulus se estende pelos três estados da região Sul do Brasil e, apesar de C. pallidulus var. pallidulus poder ser encontrada no estado de Minas Gerais, não parece ocorrer nos municípios de Ouro Branco e Ouro Preto. Allem (1978) sinonimizou C. pallidulus em C. migrans (=C. splendidus), pois, segundo ele, C. migrans seria uma espécie de ampla distribuição geográfica e de acentuadas variações vegetativas, especialmente polimorfismo foliar e de indumento. No entanto, tal proposição não foi aceita no presente trabalho e esses dois táxons são tratados como espécies distintas.

18. Croton paraguayensis Chodat., Bull. Herb. Boiss. sér. 2, 1: 396. 1901. Tipo: Paraguai, 'Inter 20-28 lat. merid. et. 59-63 long. occ., annis 1885-1895, collectae', Hassler 1866 (holótipo, G!; isótipos, K!, NY!, P!).

Figuras 10a-d; $17 \mathrm{f}$.

Nome popular: "chirca" (R. Spichiger 1600).

Subarbustos a arbustos, 0,3-1,5 m altura, monóicos; caule lepidoto, tricomas lepidoto-típicos, raios laterais parcialmente unidos (90-95\% do comprimento total), raio porrecto ausente, creme a dourados, sésseis. Folhas levemente discolores, inteiras, cartáceas a subcoriáceas, elípticas, ovais, oblongas, estreitamente elípticas a 
estreitamente oblongas, ápice agudo, mucronulado, base aguda a arredondada, margem inteira, lâmina 1,5-4,1 cm comprimento, 0,2-1,1 cm largura, nervação broquidódroma, nervura principal evidente na face adaxial, saliente na abaxial, nervuras secundárias não evidentes nas duas faces foliares, face adaxial lepidota, tricomas lepidoto-típicos, raios laterais parcialmente unidos (90-95\% do comprimento total), raio porrecto ausente, dourados a creme-esverdeados, sésseis, face abaxial lepidota, tricomas lepidoto-típicos, raios laterais parcialmente unidos (90-95\% do comprimento total), raio porrecto ausente, creme a dourados, sésseis; pecíolos 1,5-3,0 mm comprimento Inflorescências racemos bissexuados, 1,0-2,0 cm comprimento, lepidotos, tricomas lepidoto-típicos, raios laterais parcialmente unidos (90-95\% do comprimento total), raio porrecto ausente, creme a dourados, sésseis; brácteas inteiras, persistentes, 2,0-4,0 mm comprimento, lanceoladas a estreitamente triangulares, ápice agudo, face abaxial lepidota, tricomas lepidoto-típicos, raios laterais parcialmente unidos (90-95\% do comprimento total), raio porrecto ausente, creme a dourados, sésseis, face adaxial glabra. Flores estaminadas alvas a esverdeadas, 3,0-3,5 mm comprimento; pedicelos 1,5-3,0 mm comprimento; sépalas ca. 2,0 mm comprimento, coriáceas, ovais, ápice agudo, face abaxial lepidota, tricomas lepidoto-típicos, raios laterais totalmente unidos, raio porrecto ausente, creme, sésseis, face adaxial glabra; pétalas 2,5-3,5 mm comprimento, cartáceas, estreitamente elípticas, ápice agudo, ápice e terço distal da margem ciliados, tricomas simples, dourados, metade proximal da margem vilosa, tricomas simples, dourados, metade distal da face abaxial lepidota, tricomas estreladolepidotos, raios laterais parcialmente unidos (ca. de 50\% do comprimento total), raio porrecto ausente, creme, sésseis, região proximal da face adaxial vilosa, tricomas simples, alvos; estames 14, filetes ca. $1,5 \mathrm{~mm}$ comprimento, filiformes, pubescentes, tricomas simples, dourados, anteras ca. 1,0 mm comprimento, conectivos pubescentes, tricomas simples, alvos; receptáculo tomentoso, tricomas simples, dourados; disco 5-lobado. Flores pistiladas creme a esverdeadas, 3,5-6,0 mm comprimento; pedicelos 1,5-2,5 mm comprimento; sépalas desiguais, duas menores, 2,0-3,0 mm comprimento, duas médias 2,5-4,0 mm comprimento, uma maior 3,5-5,0 mm comprimento, coriáceas, estreitamente espatuladas, ápice agudo, face abaxial lepidota, tricomas lepidoto-típicos, raios laterais parcialmente unidos (90-95\% do comprimento total), raio porrecto ausente, creme, dourados a dourado-esverdeados, raio porrecto ausente, metade distal da face adaxial lepidota, tricomas lepidoto-típicos, raios laterais parcialmente unidos (90-95\% do comprimento total), raio porrecto ausente, creme, sésseis; pétalas presentes, reduzidas; disco inteiro; ovário lepidoto, tricomas lepidoto-típicos, raios laterais parcialmente unidos (90-95\% do comprimento total), raio porrecto ausente, creme a dourados, sésseis; estiletes bibífidos, primeira ramificação na metade distal, segunda ramificação na extrema porção distal, lepidotos, tricomas lepidototípicos, raios laterais parcialmente unidos (90-95\% do comprimento total), raio porrecto ausente, alvos, creme a dourados, sésseis; regiões estigmáticas 12, glabras. Frutos 4,0-5,0 mm comprimento, 4,0-5,0 mm largura; sementes ca. 4,0 mm comprimento, 2,5-3,0 mm largura, elipsóides, testa castanha a castanho-alaranjada.

Distribuição geográfica e hábitats: Croton paraguayensis é endêmica do Paraguai, onde parece ser bastante comum, ocorrendo em diversos municípios. Desenvolve-se, especialmente, em regiões com solo arenoso ou pedregoso, junto a afloramentos rochosos, entretanto pode também ser encontrada em locais com solo úmido, próximas a rios.

Fenologia: Flores foram observadas em todos os meses do ano. Frutos foram vistos em janeiro, fevereiro, outubro e dezembro.

Material examinado: Paraguai: s.d. (fl), D.E. Hassler 4038 (G, K, NY, P, W); s.d. (fl), P. Jorgensen 3519 (NY); 1914 (fl), Chodat 401 (G). Amambay: Sierra de Amambay, 1912-1913 (fl), D.E. Hassler
11279 (G, K, NY, P, W). De La Cordillera: Tobati: cerro Tobati, 11 jan. 1903 (fl, fr), K. Fiebrig 690 (P); Zobaty, cerro Capilla, fev. 1968 (fl), A. Schinini 1362 (CTES, G, P); cerro Tobati, 28 dez. 1973 (fl, fr), P. Arenas 295 (CTES); id., 3 jan. 1979 (fl), I. Basualdo 251 (G); id., Cordillera de Altos, 11 out. 1981 (fl, fr), A. Schinini \& E. Bordas 21260 (CTES); Zobaty, 25 set. 1987 (fl), R. Degen \& E. Zardini 292 (CTES); id., 28 out. 1987 (fl), R. Degen \& E. Zardini 418 (CTES); id., 18 nov. 1987 (fl), R. Degen \& E. Zardini 482 (CTES); id., 16 dez. 1987 (fl), E. Zardini \& R. Degen 4042 (F, MO); cerro Ybitú Silla, $1 \mathrm{~km}$ ao sul de Tobati, $25^{\circ} 12^{\prime} \mathrm{S}$ e $57^{\circ} 7^{\prime}$ W, elev. $297 \mathrm{~m}, 28$ jun. 1988 (fl), E. Zardini \& R. Degen 5223 (MO); Serrania de Tobati, $25^{\circ} 12^{\prime}$ 'S e $57^{\circ} 7^{\prime}$ W, elev. $297 \mathrm{~m}, 25$ ago. 1988 (fl), E. Zardini 6718 (MO); cerro Tobati, 9 jan. 1989 (fl, fr), E. Bordas 4371 (CTES, G, K). Piribebuy: 7,6 km a sudeste de Piribebuy, caminho a Paraguari, ca. $0,1 \mathrm{~km}$ a norte de A. Yhaguay Guazu, $25^{\circ} 30^{\prime} \mathrm{S}$ e $57^{\circ} \mathrm{W}, 7 \mathrm{fev}$. 1987 (fl), S. Ginzbarg, J. Davalos \& I. Fox 432 (NY); 4,6 km ao sul de Piripebuy, caminho a Paraguari, $10 \mathrm{~km}$ a leste do caminho, rio Y-acá, Salto Piraretá, $0,5 \mathrm{~km}$ a oeste do salto, $25^{\circ} 30^{\prime} \mathrm{S}$ e $56^{\circ} 55^{\prime} \mathrm{W}$, 7 fev. 1987 (fl), S. Ginzbarg, J. Davalos \& I. Fox 433 (NY); Piripebuy, $25^{\circ} 28^{\prime}$ e $57^{\circ} 1^{\prime}$ W, elev. 250 m, 30 abr. 1988 (fl), A. Charpin \& L. Ramella 21286 (G); Piripebuy-Piraretá, 10 mar. 1989 (fl), N. Soria 3180 (MO); Piripebuy, Salto Amambay, 20 abr. 1989 (fl), N. Soria 3520 (CTES); id., Salto Amambay, 20 abr. 1989 (fl), M. Ortiz 1203 (G). Valenzuela: Mbocayá guazú ty, 26 dez. 1950 (fl), G.J. Schwarz 11365 (CTES); Guazu, 5 mar. 1883 (fl), B. Balansa 4670 (G, K, P). Guaira: Colonia Independencia: cerro Peró, $25^{\circ} 55^{\prime} \mathrm{S}$ e $56^{\circ} 15^{\prime} \mathrm{W}$, mar. 1924 (fl), T. Rojas 4825 (AS n.v., MO). Villa Rica: cerro Pelado, abr. 1876 (fl), B. Balansa 1649 (G, K, P). Paraguari: cerro Cordillerita, $25^{\circ} 46^{\prime} \mathrm{S}$ e $56^{\circ} 47^{\prime} \mathrm{W}$, jul. 1932 (fl), T. Rojas 6092 (AS n.v., MO); Piraretá, 18 dez. 1965 (fl), T.M. Pedersen 7603 (CTES, NY); Parque Nacional Ybicuy, elev. 250 m, 4 set. 1977 (fl), L.C.R. Caballero 44 (G); Tebiuary Mí, próximo a Isla Alta, 17 nov. 1978 (fl), Bernardi 18718 (NY); cerro Cordillerita, 14 out. 1969 (fl), T.M. Pedersen 9286 (CTES, P); Salto Piraretá, mar. 1972 (fl), A. Schinini 4426 (CTES, P); id., 15 out. 1978 (fl), Bernardi 18044 (NY); id., margem do arroio Yhaguy Guazú, 14 nov. 1978 (fl, fr), M.M. Arbo et al. 1722 (CTES); Parque Nacional de Ybycuí, a $4 \mathrm{~km}$ da casa florestal, no caminho para La Colmena, 13 set. 1980 (fl), J.F. Casas \& J. Molero 3554 (G, NY); id., 20 jan. 1984 (fl), R. Duré \& W. Hahn 238 (CTES); id., $26^{\circ} 5^{\prime} \mathrm{S}$ e $56^{\circ}$ 50' W, 4 ago. 1984 (fl), W. Hahn 2666 (CTES, G, MO n.v.); id., limite norte do parque, caminho a oeste de Corrientes, 6 out. 1984 (fl), L. Pérez 373 (CTES, PY n.v.); id., 16 fev. 1985 (fl, fr), L.C.S. Ortega 2341 (G, MO); entre Salto Cristal e La Colmena, $25^{\circ} 50^{\prime} \mathrm{S}$ e $56^{\circ} 43^{\prime} \mathrm{W}, 25$ set. 1985 (fl), R. Spichiger \& P.A. Laizeau 1600 (G, NY); margem do arroio Corriente, Passo a Mbocarusú, 30 maio 1987 (fl), E. Zardini \& L. Pérez 2785 (G, MO n.v.); Parque Nacional de Ybicuí, 26 3' S e 56 50' W, elev. 150 m, 23 jun. 1988 (fl, fr), E. Zardini 5041 (MO, NY); id., $5 \mathrm{~km}$ ao norte do prédio da administração do parque, na estrada para César Barrientos, $26^{\circ} 3^{\prime} \mathrm{S}$ e $56^{\circ} 50^{\prime} \mathrm{W}, 14$ dez. 1988 (fl), E. Zardini 8668 (F); id., $5 \mathrm{~km}$ ao norte do prédio da administração do parque, na estrada para César Barrientos, $26^{\circ} 3^{\prime} \mathrm{S}$ e $56^{\circ} 50^{\prime} \mathrm{W}, 14$ dez. 1988 (fl), E. Zardini 8681 (F); id., 2 km ao norte de Salto Cristal $26^{\circ} 3^{\prime}$ ' S e 56 50' W, 27 jan. 1989 (fl, fr), E. Zardini \& R. Velásquez 10190 (F, MO n.v.); id., $2 \mathrm{~km}$ ao norte de Salto Cristal $26^{\circ} 3^{\prime}$ S e 56 50' W, 27 jan. 1989 (fl, fr), E. Zardini \& R. Velásquez 10191 (F, MO n.v.); id., 3 km ao norte de Salto Cristal, $26^{\circ} 3^{\prime} \mathrm{S}$ e $56^{\circ} 50^{\prime} \mathrm{W}, 27$ jan. 1989 (fl), E. Zardini \& guarda do parque 10200 (F, MO n.v.); $5 \mathrm{~km}$ ao norte do prédio da administração do parque, $26^{\circ} 3^{\prime} \mathrm{S}$ e $56^{\circ} 50^{\prime} \mathrm{W}, 18$ mar. 1989 (fl), E. Zardini \& guarda do parque 11887 (F, MO n.v); id., 5 km ao norte da área da administração, 4 jun. 1989 (fl), E. Zardini 12657 (F, MO n.v.); id., 4 km ao norte da administração, 26 4' S e 56 48' W, 31 out. 1989 (fl, fr), E. Zardini \&




18 out. 1994 (fl, fr), A. Krapovickas et al. 45698 (CTES, G); Parque Nacional Ybicui, $26^{\circ} 1^{\prime}$ S e $57^{\circ} 1^{\prime}$ W, 25 out. 2000 (fl), R. Kiesling, E.A. Ullibarri \& M. Quintana 9838 (G, SI n.v.).

Croton paraguayensis assemelha-se muito a outras espécies da seção Lamprocroton por conta, principalmente, do hábito subarbustivo a arbustivo, bastante ramificado e das folhas com indumento tipicamente lepidoto nas duas faces. Entre as espécies que são, morfologicamente, semelhantes a $C$. paraguayensis estão C. subcinerellus e C. cinerellus. Croton paraguayensis distingue-se de $C$. cinerellus, principalmente, por conta das folhas mais largas e pelos estiletes que são duas vezes bífidos e cobertos por indumento lepidoto. Além disso, enquanto C. cinerellus ocorre, exclusivamente, no Brasil, C. paraguayensis é uma espécie endêmica do Paraguai. Em contrapartida, assim como C. paraguayensis, $C$. subcinerellus também ocorre no Paraguai, porém em conjunto com as folhas mais estreitas, esta espécie apresenta flores pistiladas extremamente grandes em relação às demais espécies da seção Lamprocroton, variando de 9,0 a $11 \mathrm{~mm}$ de comprimento ao passo que em $C$. paraguayensis as maiores flores pistiladas atingem $6,0 \mathrm{~mm}$ de comprimento. Assim como em C. cinerellus, em C. subcinerellus os estiletes são, em geral, apenas simplesmente bífidos e, apesar de algumas vezes ocorrer uma segunda ramificação ela não é observada em todos os ramos dos estiletes. Croton paraguayensis pode ser distinguida das outras espécies da seção Lamprocroton, especialmente, por conta das flores pistiladas com sépalas desiguais, em geral, espatuladas e bastante coriáceas. Os estiletes lepidotos, com uma segunda ramificação na extrema porção distal, também podem ser utilizados como um caráter útil no reconhecimento da espécie.

19. Croton perintrincatus Croizat, Darwiniana 6: 450. 1944. Tipo: 'Bolivia, Huayavilla, $2300 \mathrm{~m}$ altura', [7 dez. 1903], Fiebrig 2510 (holótipo, A 47377!; isótipos, B!, NY! W!).

\section{Figuras 10e-f; 18 a.}

Subarbustos, ca. 50,0 cm altura, dióicos; caule lepidoto, tricomas lepidoto-típicos, raios laterais parcialmente unidos (80-90\% do comprimento total), raio porrecto ausente, creme, dourados a acastanhados, sésseis. Folhas levemente discolores, inteiras, cartáceas a subcoriáceas, estreitamente elípticas a estreitamente oblongas, ápice agudo a arredondado, base aguda, margem inteira, lâmina 5,0-11 mm comprimento, 1,0-2,0 mm largura, nervação hifódroma, impressa na face adaxial, saliente na abaxial, face adaxial lepidota, tricomas pseudo-lepidotos, raios laterais parcialmente unidos (ca. 20\% do comprimento total), raio porrecto presente, creme a dourados, curto-estipitados; face abaxial lepidota, tricomas dentado-lepidotos, raios laterais parcialmente unidos (ca. 70\% do comprimento total), raio porrecto ausente, creme, sésseis; pecíolos 0,5-1,5 mm comprimento Inflorescências racemos unissexuados, ca. 1,0 cm comprimento, lepidotos, tricomas lepidoto-típicos, raios laterais parcialmente unidos (80-90\% comprimento total), raio porrecto ausente, creme, dourados a acastanhados, sésseis; brácteas inteiras, persistentes, ca. 2,0 mm comprimento, linear-triangulares, ápice agudo, face abaxial lepidota, tricomas dentado-lepidotos, raios laterais parcialmente unidos (ca. 70\% do comprimento total), raio porrecto ausente, creme, sésseis, face adaxial glabra. Flores estaminadas alvas a creme, ca. 3,0 mm comprimento; pedicelos ca. 1,0 mm comprimento; sépalas ca. 2,0 mm comprimento, coriáceas, ovais, ápice agudo, face abaxial lepidota, tricomas lepidoto-típicos, raios laterais parcialmente unidos (ca. 90\% do comprimento total), raio porrecto ausente, creme a dourados, sésseis, face adaxial glabra; pétalas ca. 2,5 mm comprimento, subcartáceas, oblanceoladas, ápice arredondado, ápice e metade distal da margem ciliados, tricomas simples, alvos, metade proximal da margem vilosa, tricomas simples, alvos, face abaxial lepidota, tricomas lepidoto-típicos, raios laterais parcialmente unidos (ca. 90\% do comprimento total), raio porrecto ausente, creme a dourados, sésseis, região proximal da face adaxial vilosa, tricomas simples, alvos; estames 12 , filetes ca. 2,0 mm comprimento, filiformes, pubescentes, tricomas simples, alvos, anteras ca. 1,0 mm comprimento, conectivos glabros; receptáculo tomentoso, tricomas simples, alvos; disco 5-lobado. Flores pistiladas creme, ca. 2,5 mm comprimento; pedicelos ca. 1,5 mm comprimento; sépalas levemente desiguais, duas menores ca. $2,0 \mathrm{~mm}$ comprimento, três maiores, ca. 2,5 mm comprimento, coriáceas, largamente ovais, ápice agudo, face abaxial lepidota, tricomas lepidoto-típicos (ca. $90 \%$ do comprimento total), raio porrecto ausente, creme a dourados, sésseis, metade distal da face adaxial tomentosa, tricomas estrelados, raio porrecto presente, sésseis, alvos; pétalas ausentes; disco inteiro; ovário lepidoto, tricomas lepidoto-típicos, raios laterais parcialmente unidos (ca 90\% comprimento total), raio porrecto ausente, creme a amarelados, sésseis; estiletes bífidos, ramificados desde a base, lepidotos, tricomas lepidoto-típicos, raios laterais parcialmente unidos (ca. 90\% do comprimento total), raio porrecto ausente, alvos, sésseis; regiões estigmáticas 6 , glabras. Frutos ca. 5,0 mm comprimento, ca. 6,0 mm largura; sementes ca. 3,0 mm comprimento, ca. 2,5 mm largura, elipsóides, testa castanho-alaranjada, lisa.

Distribuição geográfica e hábitats: Croton perintrincatus foi coletada apenas na Argentina e na Bolívia. Ocorre, preferencialmente, em áreas abertas e secas, com solo rochoso, em regiões com altitudes variando dos 2.000 aos $2.300 \mathrm{~m}$.

Fenologia: Flores foram observadas nos meses de fevereiro e abril e frutos apenas em abril. Tal fato deve-se, provavelmente, ao pouco número de coletas de $C$. perintrincatus.

Material examinado: Argentina: Corrientes: San Martín: Tres Cerros, Colonia Nazareno, Colonia de Coutinho, 14 fev. 1979 (fl), A. Schinini et al. 17041 (CTES, MO); id., Colonia Pelón, 15 fev. 1979 (fl), A. Schinini et al. 17150 (CTES, MO). Bolívia: Tarija: Arce: $39,9 \mathrm{~km}$ ao sul de jet. da rodovia de Entre Rios, na estrada Padcaya, $21^{\circ} 54^{\prime} \mathrm{S}$ e $64^{\circ} 41^{\prime} \mathrm{W}$, elev. 2.100-2.200 m, 29 abr. 1983 (fl, fr), J.C. Solomon 10207 (F, MO, NY).

Croton perintrincatus é uma espécie que pode ser facilmente reconhecida por conta do hábito subarbustivo, extremamente ramificado, e das folhas muito pequenas, com aproximadamente $1,0 \mathrm{~cm}$ de comprimento, variando de estreitamente elípticas a estreitamente oblongas, densamente distribuídas nos ramos. Tais caracteres podem também ser observados em C. ericoides, espécie que ocorre, exclusivamente, na região Sul do Brasil, endêmica do estado do Rio Grande do Sul. Porém, enquanto $C$. ericoides é freqüente em dunas e nas proximidades de lagoas, em regiões com cotas altitudinais baixas, $C$. perintrincatus ocorre em áreas com afloramentos rochosos, em regiões bastante elevadas, com altitude em torno dos $2.000 \mathrm{~m}$. Além disso, o indumento da face adaxial das folhas também pode ser utilizado na distinção entre esses dois táxons já que em $C$. ericoides é constituído por tricomas lepidoto-típicos ao passo que em C. perintrincatus, por tricomas pseudo-lepidotos. Croton perintrincatus também é uma espécie bastante semelhante à C. pygmaeus, mas pode ser distinguida dessa tanto pela distribuição geográfica quanto pelo indumento da face adaxial das folhas já que C. pygmaeus também é endêmica do Rio Grande do Sul e possui a face adaxial das folhas tomentosa, com indumento formado por tricomas estrelados enquanto em $C$. perintrincatus os tricomas dessa região da folha são pseudo-lepidotos com raios laterais unidos em cerca de $20 \%$ do seu comprimento total.

Croton perintrincatus foi descrita por Croizat (1944) com base em um único material proveniente da Bolívia e, no protólogo, o autor comenta a proximidade desse táxon com outras espécies de Croton como C. ericoides, C. dusenii, C. gnaphalii Baill. e C. serpyllifolius, as duas primeiras e a última representantes da seção Lamprocroton. 
Todas essas espécies, assim como C. perintrincatus, possuem folhas relativamente pequenas e por isso, muitas vezes, pode ser difícil distingui-las. No entanto, a distribuição geográfica auxilia na identificação desses táxons, uma vez que todas essas espécies ocorrem, exclusivamente, no Brasil ao passo que $C$. perintrincatus não. $\mathrm{O}$ tipo de tricoma presente na face adaxial das folhas também auxilia no reconhecimento dessas espécies, pois em $C$. perintrincatus eles são pseudo-lepidotos, em C. dusenii, C. gnaphalii e C. serpyllifolius, estrelados e, em C. ericoides, lepidoto-típicos.

Apesar do autor (Croizat 1944) não classificar C. perintrincatus no nível seccional e nem Webster (1993) ter citado-a como uma das espécies representativas da seção Lamprocroton, os caracteres morfológicos presentes nesse táxon são aqueles descritos para a supracitada seção.

20. Croton pseudoadipatus Croizat, Darwininana 6: 456. 1944. Tipo: 'Brasil, Minas Gerais, Serra d'Itabira do Campo', [dez. 1888], Glaziou 17759a (holótipo, A 47386!; isótipo, F 47386!).

Croton russulus Croizat, Darwininana 6: 456. 1944. Tipo: 'Brasil, Minas Geraës, Serra do Cipó, ad. km 131, [14 abr. 1935], Mello Barreto 17020 (holótipo, A 47408!; isótipo, F). syn. nov.

Figuras 11a-i; $18 b$.

Subarbustos a arbustos, 0,5-1,7 m altura, monóicos; caule lepidoto, tricomas estrelado-lepidotos, raios laterais parcialmente unidos (40-50\% do comprimento total), raio porrecto presente, dourados, ferrugíneos a acastanhados, longo-estipitados. Folhas inteiras, discolores, papiráceas a cartáceas, elípticas, ovais a largamente ovais, ápice agudo a arredondado, base obtusa a reta, margem inteira, lâmina 0,8-3,7 cm comprimento, 0,6-2,5 cm largura, nervação actinódroma reticulada basal, nervuras secundárias broquidódromas, impressas na face adaxial, saliente na abaxial, face adaxial tomentosa, tricomas estrelados, raio porrecto presente, creme, dourados a ferrugíneos, sésseis a curto-estipitados, face abaxial lepidota, tricomas estreladolepidotos, raios laterais parcialmente unidos (40-50\% do comprimento total), raio porrecto presente, creme, dourados, amarelo-dourados a alvo-esverdeados, sésseis a curto estipitados; pecíolos 2,5-10,0 mm comprimento Inflorescências racemos bissexuados, 1,5-4,5 cm comprimento, lepidotos, tricomas estrelado-lepidotos, raios laterais parcialmente unidos (40-50\% do comprimento total), raio porrecto presente, dourados, ferrugíneos a acastanhados, longo-estipitados e tricomas estrelados, raio porrecto presente, dourados, ferrugíneos a acastanhados, estipitados; brácteas inteiras, persistentes, 2,0-6,0 mm comprimento, lanceoladas a estreitamente triangulares, ápice agudo, face abaxial tomentosa, tricomas estrelados, raio porrecto presente, creme, dourados a ferrugíneos, sésseis a curto-estipitados, face adaxial glabra. Flores estaminadas alvas, creme a amareladas, 2,5-5,0 mm comprimento; pedicelos 1,5-4,5 mm comprimento; sépalas 2,5-3,0 mm comprimento, coriáceas, ovais a triangulares, ápice agudo a acuminado, face abaxial lepidota, tricomas dentado-lepidotos, raios laterais parcialmente unidos (50-70\% do comprimento total), raio porrecto presente, dourados, sésseis, face adaxial glabra; pétalas ca. 3,0 mm comprimento, membranáceas, espatuladas a obovais, ápice agudo a arredondado, ápice e metade distal da margem ciliados, tricomas simples, alvos, metade proximal da margem vilosa, tricomas simples, alvos, face abaxial lepidota, tricomas lepidoto-típicos, raios laterais parcialmente unidos (80-90\% do comprimento total), raio porrecto ausente, creme a dourados, sésseis, região proximal da face adaxial vilosa, tricomas simples, alvos; estames 15-16, filetes 2,5-3,5 mm comprimento, filiformes, pubescentes, tricomas simples, alvos, anteras 0,5-1,5 mm comprimento, conectivos glabros; receptáculo tomentoso, tricomas simples, alvos; disco 5-lobado. Flores pistiladas creme, ferrugíneas, acastanhadas a alvo-ferrugíneas, 2,0-9,0 mm comprimento; pedicelos 1,5-2,0 $\mathrm{mm}$ comprimento; sépalas desiguais, duas menores, ca. 4,0 mm comprimento, três maiores, ca. 6,0 mm comprimento, coriáceas, elípticas a espatuladas, ápice agudo a acuminado, face abaxial lepidota, tricomas estreladolepidotos, raios laterais parcialmente unidos (40-50\% do comprimento total), raio porrecto presente, creme, dourados a ferrugíneos, sésseis a curto-estipitados, face adaxial tomentosa, tricomas estrelados, raio porrecto presente, creme a creme-esverdeados, sésseis; pétalas presentes, reduzidas; disco inteiro; ovário lepidoto, tricomas estrelado-lepidotos, raios laterais parcialmente unidos (40-50\% do comprimento total), raio porrecto presente, creme a dourados, sésseis; estiletes bífidos, ramificados desde a base ou, raramente, a partir da metade distal, lepidotos, tricomas estrelado-lepidotos, raios laterais parcialmente unidos (40-50\% do comprimento total), raio porrecto presente, creme a creme-esverdeados, sésseis; regiões estigmáticas 12, glabras. Frutos 6,0-8,0 mm comprimento, 6,0-10,0 mm diâmetro; sementes 3,0-4,5 mm comprimento, 2,0-2,5 mm largura, elipsóides, testa castanha a castanho-alaranjada, lisa a levemente rugosa.

Distribuição geográfica e hábitats: Trata-se de uma espécie endêmica da porção mineira da Cadeia do Espinhaço, onde foi coletada apenas nos municípios de Conceição do Mato Dentro, Cristália, Jaboticatubas, Morro do Pilar e Santana do Riacho. Croton pseudoadipatus ocorre, geralmente, em pequenas populações à borda de matas ciliares, em solo arenoso e junto a gramíneas. Pode ser encontrada também, com menos freqüiência, em formações campestres, na orla de capões e em campo rupestre, na maioria das vezes em altitudes que superam os 1.000 m (Lima \& Pirani 2003).

Fenologia: Flores foram encontradas praticamente o ano inteiro, exceto no mês de dezembro. Frutos foram observados em fevereiro, março, abril, julho e agosto.

Material examinado: Brasil: Minas Gerais: Conceição do Mato Dentro: estrada de São José de Almeida a Conceição do Mato Dentro, $8 \mathrm{~km}$ a sudoeste do rio Cipó, ca. $19^{\circ} 22^{\prime} \mathrm{S}$ e $43^{\circ} 38^{\prime} \mathrm{W}$, elev. ca. 800 m, 10 fev. 1991 (fl, fr), M.M. Arbo et al. 4816 (SPF). Cristália: Serra do Batieiro, ca. de $10 \mathrm{~km}$ do rio Itacambiruçu, em direção à Cristália, ca. 16 33' S e 42 53’ W, 12 mar. 1999 (fl, fr), A. Rapini \& M.L. Kawasaki 755 (SPF); Parque Natural Municipal do Ribeirão do Campo, 19 7' 20,32" S e 43 36' 1"'W, 13 set. 2003 (fl), R.C. Mota et al. 2144 (BHCB, SPF). Jaboticatubas: Serra do Cipó, $35 \mathrm{~km}$ ao norte, 18 jan. 1972 (fl), G. Hatschbach \& C. Koczicki 28843 (MBM, MO); km 140 ao longo da rodovia Lagoa Santa-Conceição do Mato Dentro-Diamantina, 6 mar. 1972 (fl, fr), A.B. Joly et al. 1326 (NY, SP, UEC); Serra do Cipó, 5 ago. 1972 (fl, fr), G. Hatschbach 29910 (MBM, MO). Morro do Pilar: Serra do Cipó, rodovia Belo Horizonte-Conceição do Mato Dentro (MG 010), ca. de 1,5 km antes da bifurcação entre Morro do Pilar e Conceição do Mato Dentro, 26 out. 1993 (fl), M.T.V.A. Campos \& E.D.P. Souza CFSC 13483 (SPF). Santana do Riacho: Serra do Cipó, 25 abr. 1892 (fl), Schawcke s.n. (OUPR 6124); id., jun. 1908 (fl), L. Damazio s.n. (RB 82964); id., km 131, 14 abr. 1935 (fl, fr), M. Barreto 1195 \& E. Brade 14793 (B, RB); id., 1938 (fl), J.A. Borhidi \& M. Barreto s.n. (OUPR 6148); id., km 132, ca. $153 \mathrm{~km}$ ao norte de Belo Horizonte, $17 \mathrm{fev} .1968$ (fl), H.S. Irwin, H. Maxwell \& D.C. Wasshausen 20342 (MO, NY); id., próximo ao Palácio, km 135, elev. 1200 m, 25 abr. 1978 (fl), H.C. Lima 387 (RB); id., km 137 ao longo da rodovia Belo Horizonte-Conceição do Mato Dentro, 14 ago. 1979 (fl, fr), A.M. Giulietti et al. CFSC 5628 (SP); id., rodovia Belo Horizonte-Conceição do Mato Dentro, km 127, 1 mar. 1980 (fl), A. Furlan \& M.G. Sajo CFSC 5994 (SPF); id., rodovia Belo Horizonte-Conceição do Mato Dentro, km 131, 30 mar. 1980 (fl), I. Cordeiro et al. CFSC 6075 (SPF); id., rodovia Belo HorizonteConceição do Mato Dentro, km 123, 23 jul. 1980 (fl), A.M. Giulietti et al. CFSC 6407 (SPF); id., rodovia Belo Horizonte-Conceição do Mato Dentro, km 122, mata ciliar do córrego Três Pontinhas, 3 nov. 1981 (fl), J.R. Pirani \& I. Cordeiro CFSC 7686 (SPF, UEC); id., retiro 
do Alto do Palácio, $25 \mathrm{~km}$ a nordeste de Cardeal Mota, caminho para Conceição do Mato Dentro, 12 fev. 1991 (fl), M.M. Arbo et al. 4960 (K, MO, SPF); id., retiro do Alto do Palácio, elev. ca. 1.300 m, 1 maio 1993 (fl), F. Barros 2760 (SP); id., Alto do Palácio, próximo à estátua do Juquinha, 2 maio 1993 (fl), V.C. Souza \& C.M. Sakuragui 3434 (ESA, SP); id., rodovia Belo Horizonte-Conceição do Mato Dentro (MG 010), ca. de $400 \mathrm{~m}$ antes da bifurcação entre Morro do Pilar e Conceição do Mato Dentro, 8 ago. 1993 (fl), M.T.V.A. Campos \& N. Roque CFSC 13323 (SP, SPF); id., Alto do Palácio, 18 fev. 1994 (fl), J.A. Lombardi \& F.R.N. Toledo 503 (BHCB); id., Alto do Palácio, 18 fev. 1994 (fl), J.A. Lombardi \& F.R.N. Toledo 504 (BHCB); id., em frente à estátua do Juquinha, 7 abr. 1995 (fl), A.A. Conceição, A.A. Grillo \& M. Sztutman CFSC 13930 (SPF); id., rodovia Belo Horizonte-Conceição do Mato Dentro, $118 \mathrm{~km}$, próximo à estátua do Juquinha, 27 jul. 1999 (fl), L.R. Lima et al. 36 (SPF); id., rodovia Belo Horizonte-Conceição do Mato Dentro, km 118, próximo à estátua do Juquinha, 27 jul. 1999 (fl, fr), L.R. Lima et al. 37 (SPF); id., rodovia Belo Horizonte-Conceição do Mato Dentro, km 118, próximo à estátua do Juquinha, 27 jul. 1999 (fl, fr), L.R. Lima et al. 38 (SPF); id., rodovia Belo Horizonte-Conceição do Mato Dentro, km 120, caminho à esquerda da Cachoeira da Capivara, 23 set. 1999 (fl), L.R. Lima et al. 62 (SPF); id., próximo à estrada junto à

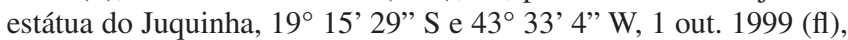
J.A. Lombardi 3226 (BHCB); id., rodovia Belo Horizonte-Conceição do Mato Dentro, 1,3 km depois da bifurcação para Morro do Pilar, margem direita da estrada, 6 jan. 2000 (fl), F.N. Costa et al. 128 (SPF); id., rodovia Belo Horizonte-Conceição do Mato Dentro, $1,3 \mathrm{~km}$ depois da bifurcação para Morro do Pilar, margem direita da estrada, 6 jan. 2000 (fl), F.N. Costa et al. 130 (SPF); id., rodovia Belo Horizonte-Conceição do Mato Dentro (MG 010), próximo à estátua do Juquinha, 23 ago. 2000 (fl), L.R. Lima et al. 132 (SPF); id., rodovia MG 010, bifurcação para Morro do Pilar, 16 jun. 2000 (fl), F.N. Costa \& P. Fiaschi 182 (SPF); id., APA Morro da Pedreira, atrás da estátua do Juquinha, 5 mar. 2002 (fl), L.R. Lima et al. 143 (SPF); id., estrada Lagoa Santa-Conceição do Mato Dentro (MG 010, km 118), 17 km ao norte do camping Véu da Noiva (Cardeal Mota), próximo ao córrego Três Pontinhas e da estátua do Juquinha, elev. 1132 m, 19 19' 12 ' 58' S e 43 33' 27' W, 18 jan. 2004 (fl), R. Riina et al. 1315 (NY, RB, SP, SPF, WIS).

Croton pseudoadipatus pode ser distinguida das demais espécies da seção Lamprocroton, especialmente, por apresentar os ramos com indumento cuja coloração varia de dourada a ferrugínea. Os tricomas lepidotos dessa região da planta são longamente estipitados, característica incomum para os demais representantes da seção. A nervação do tipo actinódroma reticulada basal é característica na espécie e é bastante conspícua na face abaxial das folhas. As inflorescências de racemos curtos, que lembram glomérulos, e as sépalas das flores pistiladas, desiguais e relativamente grandes, encobrindo o gineceu, são outros caracteres distintivos de C. pseudoadipatus.

Esta espécie foi descrita por Croizat (1944), com base em um material proveniente da Serra de Itabira do Campo, em Minas Gerais e, de acordo com esse autor, C. pseudoadipatus possui afinidades morfológicas com C. erythroxyloides. Entretanto, a distinção entre esses dois táxons pode ser feita de modo bastante simples: enquanto na primeira o indumento da face adaxial das folhas é constituído por tricomas estrelados e o da face abaxial por tricomas estreladolepidotos, com raios laterais unidos em 40 a $50 \%$ do comprimento total, na segunda as duas faces foliares são cobertas por tricomas lepidoto-típicos, com raios laterais quase que completamente unidos. Croton pseudoadipatus não foi classificada no nível de seção por nenhum dos autores que trabalhou com o gênero Croton, todavia o hábito arbustivo bastante ramificado, as folhas relativamente pequenas, o tipo de indumento, lepidoto, presente em diversas partes da planta, as sépalas das flores pistiladas desiguais e os estiletes bífidos são alguns dos caracteres citados para a seção Lamprocroton e presentes nessa espécie.

Em alguns trabalhos anteriores como Cordeiro $(1985,1992)$ e Lima \& Pirani (2003), C. pseudoadipatus foi tratada como C. julopsidium Baill., mas a análise dos materais-tipo de ambos os táxons deixou claro que esse nome foi incorretamente utilizado e que $C$. julopsidium é uma espécie que ocorre no Sul do Brasil, morfologicamente, bastante semelhante a $C$. campestris A. St.-Hill. e $C$. isabelli Baill., e que possui indumento formado por tricomas estrelados em ambas as faces foliares.

21. Croton pygmaeus L.R. Lima, Kew Bull. 63(1), no prelo. Tipo: 'Brasil, Rio Grande do Sul, Caçapava do Sul, na estrada de Caçapava para Pedra do Segredo, à esquerda da base do maior morro', 21 jan. 1994 (fl, fr), D.B. Falkenberg, J.R. Stehmann \& A.O. Vieira 6483 (holótipo, MBM; isótipos, BHCB, FLOR, UEL).

Figuras 12a-g; 18c.

Arbustos, 0,5-2,0 m altura, monóicos; caule bastante ramificado, lepidoto, tricomas lepidoto-típicos, raios laterais totalmente unidos, raio porrecto ausente, acastanhados, sésseis. Folhas fortemente discolores, inteiras, coriáceas, lineares, oblanceoladas a estreitamente oblongas, ápice agudo a acuminado, base aguda, margem inteira, lâmina 1,0-3,5 cm comprimento, 0,5-1,0 mm largura, nervação hifódroma, bastante evidente nas duas faces foliares, face adaxial tomentosa, tricomas estrelados, raio porrecto presente, creme, sésseis a curto-estipitados, face abaxial lepidota, tricomas lepidoto-típicos, raios laterais totalmente unidos, raio porrecto ausente, creme a dourados, sésseis; pecíolos 1,5-4,0 mm comprimento Inflorescências racemos unissexuados, $1,0-2,5 \mathrm{~cm}$ comprimento, lepidotos, tricomas lepidoto-típicos, raios laterais totalmente unidos, raio porrecto ausente, creme a dourados, sésseis; brácteas inteiras, persistentes, 2,0-2,5 mm comprimento, lineares, lanceoladas a estreitamente triangulares, ápice agudo, face abaxial lepidota, tricomas lepidoto-típicos, raios laterais totalmente unidos, raio porrecto ausente, creme a dourados, sésseis, face adaxial glabra. Flores estaminadas esverdeadas, 1,8-2,5 mm comprimento; pedicelos 1,0-2,5 mm comprimento; sépalas 1,5-2,0 mm comprimento, coriáceas, ovais a triangulares, ápice agudo a acuminado, face abaxial lepidota, tricomas lepidoto-típicos, raios laterais totalmente unidos, raio porrecto ausente, creme a dourados, sésseis, face adaxial glabra; pétalas 1,5-2,0 mm comprimento, membranáceas, espatuladas a oblanceoladas, ápice arredondado, ciliado, tricomas simples, alvos, metade proximal da margem vilosa, tricomas simples, alvos, faces abaxial e adaxial glabras; estames 14 , filetes ca. $1,5 \mathrm{~mm}$ comprimento, filiformes, glabros, anteras ca. 0,5 mm comprimento, conectivos glabros; receptáculo tomentoso, tricomas simples, alvos; disco 5-lobado. Flores pistiladas esverdeadas, 2,0-2,5 mm comprimento; pedicelos 0,5-1,5 mm comprimento; sépalas desiguais, duas menores, 1,5-2,0 mm comprimento, três maiores, 2,0-2,5 mm comprimento, coriáceas, estreitamente oblongas, ápice agudo, face abaxial lepidota, tricomas lepidoto-típicos, raios laterais totalmente unidos, raio porrecto ausente, dourados, sésseis, metade distal da face adaxial tomentosa, tricomas simples, creme a alvascentos; pétalas presentes, reduzidas; disco 5-lobado; ovário lepidoto, tricomas lepidoto-típicos, raios laterais totalmente unidos, raio porrecto ausente, dourados a acastanhados, sésseis; estiletes bífidos, ramificados desde a base, glabros; regiões estigmáticas 6, glabras. Frutos ca. 4,0 mm comprimento, ca. 3,5 mm largura; sementes ca. 3,0 mm comprimento, ca. 2,0 mm largura, elipsóides, testa castanha, lisa a levemente rugosa.

Distribuição geográfica e hábitats: Croton pygmaeus ocorre, exclusivamente, no Rio Grande do Sul, nos municípios de Bagé e de Caçapava do Sul. Desenvolve-se, preferencialmente, em regiões de 
capoeira, afloramentos rochosos, campos pedregosos, em geral, em áreas serranas e topo de morro.

Fenologia: Flores foram observadas nos meses de junho e novembro e frutos somente em novembro.

Material examinado: Brasil: Rio Grande do Sul: Bagé: Casa de Pedra, 8 nov. 1988 (fl), M.G. Rossoni 96 (ICN); id., 3 nov. 1989 (fl), M.G. Rossoni 225 (ICN); id., 23 nov. 1983 (fl), A.M. Girardi-Deiro et al. 984 (CNPO n.v., MBM); id., 3 nov. 1989 (fl), I. Fernandes 724 (ICN, PACA). Caçapava do Sul: Pedra do Segredo, 15 nov. 1984 (fl), L.R.M. Baptista et al. s.n. (ICN 69904); id., jun. 1986 (fl), M. Sobral et al. 5114 (ICN); id., jun. 1986 (fl, fr), M. Sobral et al. 5115 (ICN).

Croton pygmaeus é muito semelhante a C. ericoides por possuir as folhas relativamente pequenas e estreitas além de também apresentar inflorescências unissexuadas, caráter não muito comum para os representantes da seção Lamprocroton. Entretanto, os dois táxons podem ser distinguidos por conta do tipo de tricoma que forma o indumento da face adaxial das folhas: enquanto em $C$. ericoides ele é tipicamente lepidoto, com raios laterais quase que totalmente unidos, em C. pygmaeus essa região da planta é coberta por tricomas estrelados, cujos raios laterais são completamente livres. Adicionalmente, embora tanto C. pygmaeus como C. ericoides ocorram apenas no estado do Rio Grande do Sul, a segunda habita região litorânea ou próxima a lagos e lagoas ao passo que a primeira é encontrada em regiões com altitudes mais elevadas e sempre associada a afloramentos rochosos.

A presença de indumento lepidoto em diversas partes da planta como ramos, folhas, sépalas, ovário, aliada à ausência de glândulas na base das folhas, ao número de estames, à desigualdade no tamanho das sépalas das flores pistiladas e aos estiletes bífidos são algumas das características encontradas em C. pygmaeus utilizadas para classificála como um representante da seção Lamprocroton.

22. Croton serpyllifolius Baill., Adansonia 4: 355. 1864. Tipo: [Brasil], 'Prov. de Saint-Paul, prés d'un ruisseau, dans le voisinage d'Eneyda-Villa', [1816-1821], Saint-Hilaire C2-1495 (lectótipo, P!; isolectótipo, F!). Remanescente do síntipo original: [Brasil], 'Prov. de Saint-Paul, prés d'un ruisseau, dans le voisinage d'Eneyda-Villa', [1816-1821], SaintHilaire $\mathrm{C} 2-1580$ (P!).

Figuras $11 \mathrm{j}-\mathrm{n}$; $18 \mathrm{~d}$.

Subarbustos a arbustos, 30,0-50,0 cm, monóicos; caule lepidoto, tricomas lepidoto-típicos, raios laterais parcialmente unidos (ca. 90\% do comprimento total), raio porrecto ausente, creme a dourados, sésseis. Folhas levemente discolores, inteiras, cartáceas, estreitamente elípticas, ápice agudo, base aguda, margem inteira, lâmina 0,6-1,0 cm comprimento, 0,1-0,3 cm largura, nervação hifódroma, nervura primária pouco evidente na face adaxial, saliente na abaxial, face adaxial tomentosa, tricomas apresso-estrelados, raios laterais parcialmente unidos (ca. 10\% do comprimento total), raio porrecto ausente, alvos a creme, sésseis, face abaxial lepidota, tricomas lepidoto-típicos, raios laterais parcialmente unidos (80-90\% do comprimento total), raio porrecto ausente, creme, sésseis; pecíolos 1,5-2,5 mm comprimento Inflorescências racemos bissexuados, 0,9-1,2 cm comprimento, lepidotos, tricomas lepidoto-típicos, raios laterais parcialmente unidos (ca. 90\% do comprimento total), raio porrecto ausente, creme a dourados, sésseis; brácteas inteiras, persistentes, ca. 2,5 mm comprimento, linear-triangulares, ápice acuminado, face abaxial lepidota, tricomas estrelado-lepidotos, raios laterais parcialmente unidos (ca. 50\% do comprimento total), raio porrecto ausente, alvos a creme, sésseis a curto-estipitados, metade distal da face adaxial lepidota, tricomas estrelado-lepidotos, raios laterais parcialmente unidos (ca. 50\% do comprimento total), raio porrecto ausente, alvos a creme, sésseis. Flores estaminadas alvas, ca. 2,5 mm comprimento; pedicelos ca. $3,0 \mathrm{~mm}$ comprimento; sépalas ca. 2,0 mm comprimento, cartáceas, ovais, ápice agudo, face abaxial lepidota, tricomas lepidoto-típicos, raios laterais parcialmente unidos (80-90\% do comprimento total), raio porrecto ausente, creme, sésseis, face adaxial glabra; pétalas ca. 2,0 mm comprimento, membranáceas, ovais, ápice acuminado, ciliado, tricomas simples, alvos, metade proximal da margem vilosa, tricomas simples, alvos, face abaxial glabra, região proximal da face adaxial tomentosa, tricomas simples, alvos; estames 11, filetes ca. 2,0 mm comprimento, levemente subulados, glabros, anteras ca. 1,0 mm comprimento, conectivos glabros; receptáculo tomentoso, tricomas simples, alvos; disco 5-lobado. Flores pistiladas esverdeadas, ca. 3,0 mm comprimento; pedicelos ca. 1,5 mm comprimento; sépalas iguais, ca. 2,5 $\mathrm{mm}$ comprimento, coriáceas, triangulares, ápice acuminado, face abaxial lepidota, tricomas lepidoto-típicos, raios laterais parcialmente unidos (80-90\% do comprimento total), raio porrecto ausente, creme a dourados, sésseis, metade distal da face adaxial tomentosa, tricomas apresso-estrelados, raios laterais parcialmente unidos (ca. 10\% do comprimento total), raio porrecto ausente, creme a dourados, sésseis; pétalas presentes, reduzidas; disco 5-lobado; ovário tomentoso, tricomas apresso-estrelados, raios laterais parcialmente unidos (ca. 10\% do comprimento total), raio porrecto ausente, dourados, sésseis; estiletes bibífidos, primeira ramificação na base, segunda ramificação na extrema porção distal, tomentosos, tricomas apresso-estrelados, raios laterais parcialmente unidos (ca. $10 \%$ do comprimento total), raio porrecto ausente, creme, sésseis; regiões estigmáticas 6 a 12, glabras. Frutos ca. 7,0 mm comprimento, ca. 6,0 mm largura; sementes ca. 4,0 mm comprimento, ca. 3,0 mm largura, elipsóides, testa castanho-alaranjada, lisa.

Distribuição geográfica e hábitats: De acordo com Govaerts et al. (2000), C. serpyllifolius ocorre no Brasil, nos estados de São Paulo e Paraná e também na Argentina. Entretanto, todos os materiais aqui examinados, inclusive o tipo, são provenientes de São Paulo, de áreas de cerrado. Trata-se de uma espécie exclusiva do sul-sudoeste de São Paulo. A distribuição geográfica mais ampla proposta por Govaerts et al. (2000) deve se tratar de um erro de identificação dos materiais analisados por esses autores, problema bastante comum no gênero Croton.

Fenologia: Flores foram observadas em abril, maio e novembro e frutos apenas em maio. O pequeno período fenológico é, certamente, reflexo do pouco número de materiais examinados.

Material examinado: Brasil: São Paulo: Itapeva: Estação Ecológica de Itapeva, 24 4' 25' 'S e 49 3' 9' W, 12 nov. 1994 (fl), V.C. Souza et al. 7030 (ESA, SP). Itararé: fazenda Santa Andréia, 1 abr. 1989 (fl), C.A. Scaramuzza 172 \& V.C. Souza 792 (ESA, SP); id., 14 maio 1989 (fl, fr), C.A. Scaramuzza 257 \& V.C. Souza 877 (ESA, SP).

Existem poucas coleções de $C$. serpyllifolius, todas provenientes de regiões de cerrado do estado de São Paulo. Por conta do escasso número de materiais a observação da variabilidade morfológica dessa espécie ficou comprometida. Croton serpyllifolius é bastante semelhante a $C$. cinerellus, da qual pode ser distinguida, principalmente, pelo tipo de indumento da face adaxial das folhas que, na primeira, é formado por tricomas apresso-estrelados e na segunda por tricomas lepidoto-típicos. As sépalas das flores pistiladas iguais e triangulares encontradas em C. serpyllifolius e, desiguais e estreitamente oblongas em $C$. cinerellus também são úteis ma separação entre esses dois táxons. Além disso, enquanto $C$. cinerellus ocorre em regiões de cerrado e cerradão de Minas Gerais e do Mato Grosso do Sul, C. serpyllifolius parece ser endêmica do estado de São Paulo.

De acordo com Baillon (1864) e Mueller (1866, 1873), C. serpyllifolius apresenta folhas pequenas, com no máximo $10 \mathrm{~mm}$ de comprimento e $6 \mathrm{~mm}$ de largura, com a face adaxial coberta por tricomas estrelados. Esses caracteres foram aqui corroborados e são de fácil utilização no reconhecimento do táxon. 
23. Croton splendidus Mart. in Colla, Herb Pedem. 5: 110. 1836. Tipo: [Brasil], ‘Cabo Frio', Martius s.n. (holótipo, M!, isótipo, P!).

Croton migrans Casar., Nov. Stirp. Bras. 88. 1845. Tipo: [Brasil], 'Reperi in sylvulis arenosis maritimis (vulgo restingas) in provincia Rio de Janeiro', [ago. 1839], Casaretto 1255 (lectótipo, TO!). Remanescente do síntipo original: 'Accepi etiam ex interiore Brasiliae provinciâ Minas Geraes', [Serra d'Itatiaya], Claussen 2948 (TO!).

Figuras 13a-f; 19a.

Subarbustos a arbustos, 0,3-4,0 m altura, monóicos; caule lepidoto, tricomas lepidoto-típicos, raios laterais parcialmente unidos (ca. de 95\% do comprimento total), raio porrecto ausente, creme a dourados, sésseis. Folhas fortemente discolores, inteiras, cartáceas, estreitamente elípticas a elípticas, ápice agudo, acuminado a levemente arredondado, mucronulado, base aguda, às vezes, assimétrica, margem inteira, lâmina 0,8-3,5 cm comprimento, 0,2-0,8 cm largura, nervação broquidódroma, nervura primária impressa na face adaxial, saliente na abaxial, nervuras secundárias, geralmente, não evidentes nas duas faces foliares, face adaxial tomentosa, tricomas estrelados, raio porrecto presente, alvos a creme, sésseis a curto-estipitados, face abaxial lepidota, tricomas lepidoto-típicos, raios laterais parcialmente unidos (ca. de 95\% do comprimento total), raio porrecto ausente, creme, acastanhados, creme-esverdeados a alvo-esverdeados, região central dourada a acastanhada, sésseis; pecíolo 1,0-6,0 mm comprimento Inflorescências racemos bissexuados, $0,7-2,5 \mathrm{~cm}$ comprimento, lepidotos, tricomas lepidoto-típicos, raios laterais parcialmente unidos (ca. de 95\% do comprimento total), raio porrecto ausente, creme a dourados, sésseis; brácteas inteiras, persistentes, 1,5-4,0 mm comprimento, lanceoladas a estreitamente triangulares, ápice agudo, face abaxial lepidota, tricomas lepidoto-típicos, raios laterais parcialmente unidos (ca. de 95\% do comprimento total), raio porrecto ausente, creme a dourados, sésseis, face adaxial glabra. Flores estaminadas creme, alvas a amareladas, 1,0-3,5 mm comprimento; pedicelos 0,5-2,5 mm comprimento; sépalas 1,5-2,0 mm comprimento, coriáceas, ovais a elípticas, ápice agudo a arredondado, face abaxial lepidota, tricomas lepidoto-típicos, raios laterais parcialmente unidos (ca. de 95\% do comprimento total), raio porrecto ausente, creme a dourados, sésseis, face adaxial glabra a, raramente, pubescente, tricomas simples, adpressos, alvos, adpressos; pétalas 2,0-3,5 mm comprimento, membranáceas, estreitamente elípticas a espatuladas, ápice agudo, ápice e metade distal da margem ciliados, tricomas simples, alvos, metade proximal da margem vilosa, tricomas simples, alvos, face abaxial lepidota, tricomas lepidoto-típicos, raios laterais parcialmente unidos (ca. 95\% do comprimento total), raio porrecto ausente, creme, sésseis, região proximal da face adaxial vilosa, tricomas simples, alvos; estames (9-)11(-13), filetes 1,0-2,0 mm comprimento, levemente subulados, pubescentes, tricomas simples, alvos, anteras $0,5-1,5 \mathrm{~mm}$ comprimento, conectivos glabros; receptáculo tomentoso, tricomas simples, alvos; disco 5-lobado. Flores pistiladas creme, alvas, amareladas a creme-esverdeadas, 3,0-4,0 mm comprimento; pedicelos 1,0-2,0 mm comprimento; sépalas iguais, 3,0-3,5 mm comprimento, coriáceas, obovais a largamente espatuladas, ápice agudo, face abaxial lepidota, tricomas lepidoto-típicos, raios laterais parcialmente unidos (ca. de $95 \%$ do comprimento total), raio porrecto ausente, creme a dourados, sésseis, face adaxial tomentosa, tricomas estrelados, raio porrecto presente, alvos a creme, sésseis a curto-estipitados; pétalas presentes, reduzidas; disco 5-lobado; ovário lepidoto, tricomas lepidoto-típicos, raios laterais parcialmente unidos (ca. de $95 \%$ do comprimento total), raio porrecto ausente, dourados a acastanhados, sésseis; estiletes bífidos, ramificados desde a base, glabros a pubescentes, especialmente na região proximal, tricomas estrelados, raio porrecto presente, alvos a creme, sésseis; regiões estigmáticas 6, glabras. Frutos 3,0-5,0 mm comprimento, 3,0-5,0 mm diâmetro; sementes ca. 4,0 mm comprimento, ca. 2,5 mm largura, elipsóides, testa castanho-alaranjada, lisa.

Distribuição geográfica e hábitats: Segundo Smith et al. (1988) a área de distribuição desta espécie compreende os estados de Minas Gerais, Espírito Santo, Rio de Janeiro, Paraná e Santa Catarina, distribuição ora corroborada. Trata-se de uma planta heliófila que ocorre nos mais diversos tipos de ambientes como restinga aberta, campo, campo rupestre, campo cerrado e borda de capão. Também foi coletada em campos de altitude e junto a matas nebulares. Pode ser encontrada tanto em locais com solo arenoso, de restinga e margem de rios, quanto em ambientes com solo pedregoso, como o dos campos rupestres. Foi coletada também, menos freqüentemente, em matas de galeria, como a do rio Caraça, no município de Santa Bárbara (MG) e a do Rio dos Papagaios, no município de Palmeira (PR). Existe uma coleção (Dombrowski 12228), proveniente de uma área de cerrado, na Chapada de Santo Antônio, no município de Jaguariaíva (PR), porém C. splendidus não parece ser freqüente nesse tipo de ambiente. Desenvolve-se, preferencialmente, como espécie de altitude entre os 1.000 e $1.600 \mathrm{~m}$ de altura, entretanto ocorre também ao nível do mar, nas restingas, porém segundo Smith et al. (1988), nesse tipo de ambiente, bem como nos campos litorâneos, ocorre esporadicamente como elemento raro e estranho.

Fenologia: Floresce durante o ano inteiro. Frutos não foram observados nos meses de março, maio, junho, setembro e dezembro.

Material examinado: Brasil: s.d. (fl), Riedel s.n.(P); s.d. (fl), Sellow 646 (K); s.d. (fl), Sellow 2112 (NY); s.d. (fl), Riedel s.n. (NY s.n.); Brasil meridional, s.d. (fl), Sellow 216 (MO 713898, NY s.n.); id., s.d. (st), M. Gandover s.n. (MO 1905224). Espírito Santo: Castelo: Forno Grande, 6 dez. 1956 (fl), E. Pereira 2129 (RB). Espera Feliz: Parque Nacional do Caparaó, 27 maio 1999 (fl), W. Forster \& L.S. Leoni 61 (ESA, SP) Minas Gerais: s.d. (fl), Langsdorff s.n. (K); s.d. (fl), M. Claussen 6 (NY, P); s.d. (fl), M. Claussen 60 (NY, P); 1830 (fl), Custódio 61 (P); 1833 (fl), C. Gaudichaud 176 (P); ago.-abr. 1840 (fl), P. Claussen s.n. (K, P); Cachoeira do Campo, s.d. (fl), Riedel s.n. (W); Serra de Itatiaia, 1842 (fl), P. Claussen s.n. (GDC); id., s.d. (fl), P. Claussen 6 (K, P); id., ago.-abr. 1840 (fl) P. Claussen 451 (G). Aiuruoca: Pico do Papagaio, 19 abr. 1878 (fl), M.A. Glaziou s.n. (P); 16 jun. 1943 (fl), M. Magalhães 4997 (IAN). Alto Caparaó: Parque Nacional do Caparaó, caminho entre Tronqueira e o Pico da Bandeira, $20^{\circ} 25^{\prime} 4^{\prime \prime}$ 'S e $41^{\circ} 48^{\prime} 27,4$ ' W, elev. entre 1.970 e 2.890 m, 2 set. 1996 (fl), V.C. Souza et al. 12193 (ESA, SP). Caparaó: Serra do Caparaó, elev. 2.650 m, 25 nov. 1929 (fl), Y. Mexia 4012 (K, MO, NY, P, WIS); Pico do Caparaó, Serra da Bandeira, elev. 9.200 m, 3 mar. 1959 (fl), H.S. Irwin 2769 (F, NY); Serra do Caparaó, Macieiras, 14 nov. 1960 (fl), B. Flaster 97 (MBM); id.,elev. 1.950 m, 18 mai 1971 (fl), A.P. Duarte 13968 (RB); elev. 2.000 m, 9 jul. 1976 (fl), L. Krieger, Leise \& Márcio 1467 (SP,UFJF n.v.); Pico da Bandeira, 6 set. 1977 (fl), G.J. Shepherd et al. 5776 (HRCB, MBM, UEC); Serra do Caparaó, 19 mar. 1988 (fl), R.F.N. Camargo et al. 23 (SP, UFJF n.v.); Parque Nacional do Caparaó, perto da Tronqueira,1 maio 1988 (fl), L. Krieger et al. 22299 (SP, UFJF n.v.);id., Vale Verde, 19 nov. 1988 (fl), L. Krieger et al. 537 (SP, UFJF n.v.). Carangola: Serra da Gramma, elev. 1.700 m, 1 fev. 1930 (fl), Y. Mexia 4288 (K, MO, NY, P, WIS). Carrancas: Cachoeira da Zilda, 6 out. 1998 (fl), L.S. Kinoshita, C. Kozera \& A.M. Filliettaz, 98-241 (UEC). Lima Duarte: Parque Estadual do Ibitipoca, próximo à nascente do rio Salto, 12 nov. 1987 (fl), H.O. Sousa s.n. (BHCB 16017); id., mata ciliar do Lago Espelho, 28 abr. 1989 (fl), A.P. Duarte \& M.A.D. 1187 (BHCB). Ouro Branco: Serra do Itatiaia, jun. 1972 (fl), J. Badini s.n. (OUPR 5549). Ouro Preto: Morro do Carvalho, s.d. (fl), H. Magalhães 7036 (OUPR); Serra do Itatiaia, s.d. (fl), M.A. Lisboa s.n. (OUPR 6103); 6 dez. 1907 (fl), A. Baeta s.n. (OUPR 6099); Alto do Cabloco, 12 ago. 1937 (fl), M. Barreto 9115 (BHCB); Serra de Lavras Novas, 18 jan. 1942 (fl), M. Magalhães 1062 
(BHCB); Lavras Novas, Serra de Lavras Novas, ca. $20 \mathrm{~km}$ ao sul de Ouro Preto, 26 ago. 1960 (fl, fr), B. Maguire, G.M. Magalhães \& C.K. Maguire 49293 (NY); Chapada, elev. 1.150 m, 5 fev. 1978 (fl), A. Krapovickas \& C.L. Crsitóbal 33543 (CTES); Chapada, 24 maio 1979 (fl), L Mantone et al. 845 (RB); Serra do Itatiaia, jul. 1979 (fl, fr), s.c. (OUPR 6102); Chapada, elev. 1.200-1.300 m, 5 ago. 1980 (fl), H.C. Lima et al. 1284 (R n.v., RB); Falcão, 6 jun. 1985 (fl), J. Badini s.n. (OUPR 6104); id., 6 jun. 1985 (fl), J. Badini s.n. (OUPR 6105). Santa Bárbara: Serra do Caraça, s.d. (fl), Martius 1130 (M); id, jun. 1907 (fl), L. Damazio s.n. (OUPR 6101); id., 1912 (st.), J.S. Tavares 323 (M); id., 14 abr. 1933 (fl), M. Barreto 2699 (BHCB); id., fev. 1957 (fl), E. Pereira 2548 \& G. Pabst 3384 (B); Catas Altas, Serra do Caraça, ca. $10 \mathrm{~km}$ a oeste de Barão de Cocais, elev. ca. 1.400 m, 22 jan. 1971 (fl), H.S. Irwin, R.M. Harley \& E. Onishi 28851 (K, RB, MO, NY); Serra do Caraça, 17 nov. 1977 (fl), N.D. Cruz et al. 6320 (RB, UEC); id., 18 nov. 1977 (fl), N.D. Cruz et al. 6389 (UEC); id., 12 dez. 1978 (fl, fr), H.F. Leitão-Filho et al. 9570 (UEC); id., 22 fev. 1980 (fl), J.A. Oliveira 146 (BHCB); id., orla do tanque grande, 1 maio 1980 (fl), T.S.M. Grandi \& Tales 143 (BHCB); id., a $1 \mathrm{~km}$ do hotel, trilha para a piscina, 9 jan. 1982 (fl), N. Hensold et al. CFCR 2777 (SPF); id., caminho para a Cascatona, 18 dez. 1982 (fl), J.R. Pirani, D.M. Vital \& E. Favalli 367 (SP, SPF); id., caminho para a Cascatinha, atrás do monastério, Parque Natural do Caraça, $20^{\circ} 15^{\prime} \mathrm{S}$ e $43^{\circ} 30^{\prime} \mathrm{W}$, elev. 1.300 m, 16 jan. 1985 (fl), E. Zardini \& C. Farney 49614 (MO); id., caminho para Belchior, 12 dez. 1986 (fl), M.B. Horta et al. 25 (BHCB); id., caminho para a piscina, 23 maio 1987 (fl), M.B. Horta et al. 213 (BHCB); id., caminho para a Cascatinha, 28 set. 1987 (fl), M.B. Horta et al. 266 (BHCB); id., Cascatinha, 28 set. 1987 (fl), M.M.N. Braga s.n. (BHCB 13374, SP 238035, SPF 238035); id., Parque Estadual do Caraça, caminho para a Cascatinha, 29 abr. 1988 (fl), I.R. Andrade et al. 291 (BHCB); id., caminho para o tanque grande, 6 out. 1988 (fl), N.C. Attala 74 (BHCB); id., caminho para a Cascatinha, 29 abr. 1988 (fl), M.B. Horta et al. s.n. (BHCB 12333); id., caminho para a Mata dos Pinheiros, 6 out. 1988 (fl), N.C. Attala 62 (BHCB); id., Seminário do Caraça, caminho para a Cascatinha, 26 jul. 1989 (bt, fr), S. Romaniuc Neto \& I. Cordeiro 890 (G, MBM, NY, SP, SPF); id., Colégio Caraça, caminho da Cachoeirinha, 14 mar. 1990 (fl), W.M. Ferreira et al. 196 (SPF, UEC); id., a sudoeste de Catas Altas, Cascatinha, 20 $5^{\prime} \mathrm{S}$ e 43 $27^{\prime}$ W, elev. 1.270-1.350 m, 14 maio 1990 (fl), M.M. Arbo et al. 4050 (SP, SPF); id., 10 set. 1990 (fl), J.R. Stehmann et al. s.n. (BHCB 28399, MBM 194132, SPF 112245); id., trilha entre o Mosteiro e a Cascatinha, 12 out. 1992 (fl), V.C. Souza \& C.M. Sakuragui 2073 (ESA); id., Parque do Caraça, Serra de Catas Altas, 10 jan. 1996 (fl), V.C. Souza et al. 10013 (CESJ n.v., CTES n.v., ESA, UNIP n.v.); id., 2 out. 1999 (fl), R.C. Mota 83 (BHCB); id., 8 maio 2003 (fl), L.R. Lima et al. 314 (SPF); id., 8 maio 2003 (fl), L.R. Lima et al. 315 (SPF); id., 8 maio 2003 (fl), L.R. Lima 316 (SPF); id., estrada para o santuário, 20 5' $\mathrm{S}$ e $43^{\circ} 28^{\prime} \mathrm{W}$, elev. $1.200 \mathrm{~m}, 28$ jan. 2004 (fl, fr), R. Riina et al. 1372 (RB, SP, SPF, WIS). Tombos: alto da Pedra Dourada, 10 jun. 1941 (fl), J.E. Oliveira 578 (BHCB, MBM). Paraná: 17 jun. 1946 (fl), G. Hatschbach s.n. (PACA 33645). Balsa Nova: Tamanduá, 29 ago. 1979 (fl), L.T. Dombrowski 1014 (MBM). Bocaiúva do Sul: Serra da Bocaina, 8 abr. 1998 (fl), J.M. Silva \& L.M. Abe 2320 (MBM). Campina Grande do Sul: Serra do Capivari Grande, elev. 1.750 m, 6 ago. 1961 (fl), G. Hatschbach 8184 (MBM); Pico Caratuva, elev. 1.950 m, 20 maio 1967 (fl), G. Hatschbach 16461 (B, M, MBM, P, WIS); Serra do Ibitiraquire, Morro do Luar, elev. 1.300 m, 17 set. 1967 (fl), N. Imaguire 291 (MBM); Serra do Capivari Grande, elev. 1700 m, 14 jun. 1969 (fl), G. Hatschbach 21646 (MBM, MO, NY); id., 18 jul. 1986 (fl), J. Cordeiro \& J.M. Silva 312 (G, HRB, MBM); id., 24 ago. 1989 (fl), V. Nicolack \& O.S. Ribas 12 (MBM, HUCS); id., elev. 1.200 m, 13 mar. 1990 (fl), J.M. Silva \& J. Cordeiro 833 (ESA, G, MBM); Pico Paraná, elev. 1.887 m, 5 jul. 1991 (fl), C.V. Roderjan \& E. Struminski 950 (MBM);
Serra do Capivari, elev. 1.200 m, 5 set. 1991 (fl), O.S. Ribas et al. 379 (BHCB, MBM, SP, W); Serra do Ibitiraquire, subida para o Pico Paraná, elev. 1.500-1.700 m, 14 jul. 1996 (fl), O.S. Ribas \& F. Schwerdt 1449 (MBM); Serra do Capivari, 26 nov. 1996 (fl), A.C. Cervi \& R.C. Tardivo 6226 (MBM, UEC, UPCB n.v.); id., elev. 1.520 m, 21 maio 1998 (fl), C.V. Roderjan \& Y.S. Kuniyoshi 1503 (EFC n.v., MBM); Pico Caratuva, 16 abr. 2004 (fl, fr), L.R. Lima, J.M. Silva \& O.S. Ribas 357 (MBM, SP, SPF, RB, WIS). Campo Largo: Rio dos Papagaios, 17 jun. 1946 (fl), G. Hatschbach s.n. (MBM 39978); serra São Luiz de Puruña, 23 fev. 1960 (fl), E. Pereira 5455 (B). Guarapuava: fazenda Reserva, $85 \mathrm{~km}$ a sudoeste de Guarapuava, no rio Reserva, 18 mar. 1967 (fl), W. Punt \& J.C. Lindeman 1969 (SP). Jaguariaíva: Chapada Santo Antônio, 20 nov. 1980 (fl), L.T. Dombrowski 12228 (MBM). Morretes: Parque

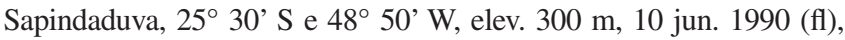
I. Rauscher 3 (NY, W); Parque Estadual do Marumbi, Pico da Boa Vista, elev. 1.300 m, 10 dez. 2001 (fl), P.H. Labiak \& M. Kaehler 2067 (MBM). Palmeira: Rio do Salto, elev. 860 m, 29 mar. 1959 (fl), G. Hatschbach 5571 (MBM); Rio dos Papagaios, 12 out. 1970 (fl), L.T. Dombrowski \& Y. Knaiyoshi 2963 (P); id., 11 mar. 1973 (fl), L.T. Dombrowski 4532 (MBM); 17 ago. 1977 (fl), L.T. Dombrowski \& P. Scherer 102 (MBM); Rodovia do Café, rio Tibagi, 16 nov. 1977 (fl, fr), G. Hatschbach 40224 (MBM); 29 ago. 1979 (fl), L.T. Dombrowski \& P. Scherer 10639 (MBM); Rio dos Papagaios, 20 jun. 1989 (fl), L.T. Dombrowski 13894 (MBM); id., 22 abr. 1993 (fl), A.C. Cervi et al. 4086 (MBM, UPCB n.v); rio Lajeado, 5 jul. 1997 (fl), O.S. Ribas \& L.B.S. Pereira 1889 (MBM, G, SPF); Recanto dos Papagaios, Rio dos Papagaios, 5 set. 1997 (fl), E.P. Santos \& C.M.S. Coimbra 329 (BHCB, G, UPCB n.v.). Ponta Grossa: Rodovia do Café, rio Tibagi, elev. $780 \mathrm{~m}$, 12 ago. 1962 (fl), G. Hatschbach 9223 (MBM); limite entre Ponta Grossa e Palmeira, rio Tibagi, ca. $25^{\circ} 20^{\prime} \mathrm{S}$ e $49^{\circ} 50^{\prime} \mathrm{W}$, elev. ca. $1.000 \mathrm{~m}$, 16 nov. 1977 (fl), L.R. Landrum 2546 (MBM); Rio dos Papagaios, $25^{\circ} 25^{\prime} \mathrm{S}$ e $49^{\circ} 44^{\prime}$ W, 12 nov. 1997 (fl), A.C. Cervi et al. 6420 (NY, UPCB n.v.); formador do rio Tibagi, cruzamento BR 376, 31 jan. 1999 (fl), S.R. Ziller 1725 (MBM). Quatro Barras: Morro do Anhangava, elev. 1.100-1.200 m, 7 jun. 1981 (fl), N. Imaguire 5618 (MBM); id., 14 jun. 1981 (fl), R. Kummrow 1525 (MBM, SPF, WIS); Serra da Baitaca, elev. 1.400 m, 9 abr. 1989 (fl, fr), C.V. Roderjan 774 (EFC n.v., MBM); id., elev. 1.400 m, 6 abr. 1990 (fl), Y.S. Kuniyoshi \& F. Galvão 5513 (MBM, W); Morro do Anhangava, 3 maio 1994 (fl), N. Silveira 11860 (MBM); Serra da Baitaca, 24 out. 1996 (fl), J. Cordeiro \& J.M. Cruz 1355 (MBM); Morro do Anhangava, elev. 1.300 m, 1 nov. 1996 (fl), E.P. Santos, H. Meneses \& R. Anjos 157 (G, UPCB n.v.); Serra da Baitaca, Morro do Anhangava, $25^{\circ} 23^{\prime} 10^{\prime \prime} \mathrm{S}$ e $49^{\circ} 0$ ' $16^{\prime}$ ' W, elev. 1.240 m, 9 maio 1998 (fl), F. França, E. Melo \& D.F. Pereira 2522 (HUEFS s.n., SP). Rio Branco do Sul: Caeté, 6 out. 1977 (fl), G. Hatschbach 40358 (MBM, MO n.v.); Serra do Bromado, 9 fev. 1982 (fl), G. Hatschbach 44543 (MBM, MO n.v.). Tibagi: Salto Conceição, Fazenda Monte Alegre, margem do rio Tibagi, 3 maio 1958 (fl), G. Hatschbach 4566 (MBM, PACA); balsa para Piraí, margem do rio Tibagi, elev. 696 m, 5 jun. 1959 (fl), G. Hatschbach 6027 (MBM); bancos de areia do rio Tibagi, 25 jun. 1967 (fl), J.C. Lindeman \& J.H. Haas 5536 (NY); Taipa de Pedra, 19 out. 1993 (fl, fr), G. Hatschbach \& J. Cordeiro 59670 (MBM); arredores da cachoeira, tributário do rio Tibagi, 3 nov. 1995 (fl), F.C. Silva \& L.H. Soares-Silva 1787 (SP);13 set. 1997 (fl), E.R. Barbosa \& W.N. Silva Jr. s.n. (FUEL 2139 n.v., SP 338838). Rio de Janeiro: s.d. (fl), M.A. Glaziou 728 (K, P); s.d. (fl), Sellow 817 (P); s.d. (fl), Schott 1621 (W); s.d. (fl), Schuech s.n. (W); s.d. (fl), Vauthier s.n. (W); 1833 (fl), Schott 4200 (G, W); 1841 (fl), Martius 846 (GDC, K, M, NY, P, W); 1907 (fl), M.A. Glaziou 7821 (P). Cabo Frio: 18 set. 1881 (fl), M.A. Glaziou 13175 (IAN, P); 22 jul. 1947 (fl), A.B. Joly s.n. (SPF 19660); Praia do Pontal, $22^{\circ} 56^{\prime} 48^{\prime \prime} \mathrm{S}$ e $42^{\circ} 1$ ' 54" W, próximo ao nível do mar, 17 abr. 1952 (fl), L.B. Smith et al. 6617 (NY); a oeste da cidade, 18 mar. 1964 (fl), K. Lems s.n. (NY s.n.); 
Restinga de Cabo Frio, 9 out. 1968 (fl), D. Sucre \& G. Barroso 3863 (RB n.v., G, M, NY). Casimiro de Abreu: perto de Rio das Ostras, jan. 1989 (fl), A. Souza s.n. (F 2170918). Macaé: fazenda Crubixaca, em direção ao Pico do Frade, 30 jul. 1982 (fl), C. Farney 50 (GUA n.v., RB); Pico do Frade, elev. 1.000 m, 16 set. 1982 (fl), C. Farney \& G. Martinelli 105 (F, GUA n.v., K, RB); trilha para o Pìco do Frade, elev. 1.400 m, 14 ago. 2001 (fl), M.G. Bovini et al. 2057 (RB, SPF). Nova Friburgo: 11 out. 1881 (fl), M.A. Glaziou 13174 (K, P); Pedra do Suspiro, 31 jul. 1887 (fl), M.A. Glaziou 17216 (NY, P); Cônego, Pedra do Imperador, alto da pedra, em trilha calçada que leva à torre, $22^{\circ} 19^{\prime} 14^{\prime \prime} \mathrm{S}$ e 42 31' 57" W, elev. $1.380 \mathrm{~m}, 16$ jun. 2004 (fl), R. Mello-Silva et al. 2621 (K, MBM, SP, SPF, WIS). Rio de Janeiro: Restinga da Tijuca, 29 mar. 1872 (fl), M.A. Glaziou 6128 (K, P); dez. 1878 (fl), M.A. Glaziou 17216 (K); id., 4 abr. 1945 (fl), O. Machado s.n. (K, RB 71131 n.v.); Restinga de Itapeba, 11 jun. 1960 (fl), H.F. Martins 125 (B); Restinga de Jacarepaguá, 13 ago. 1961 (fl), G.F.J. Pabst 5681 (B); Recreio dos Bandeirantes, 11 ago. 1963 (fl), E. Pereira 7653 (M, MBM, NY); id., 7 fev. 1964 (fl), W. Hoehne 5580 (NY, SP, SPF); id., $30 \mathrm{~km}$ a oeste do Rio de Janeiro, 5 mar. 1964 (fl), K. Lems s.n. (NY s.n.); id., 23 mar. 1964 (fl), W. Hoehne 5626 (NY, SP, SPF); Restinga de Jacarepaguá, 3 maio 1966 (fl), D.R. Hunt 5408 (K); Restinga da Tijuca, 4 maio 1966 (fl), C.L. Falcão, E.F. Guimarães \& D. Sucre 1 (F); Recreio dos Bandeirantes, $3 \mathrm{~km}$ do canal de Sernambetiba, 11 nov. 1967 (fl), J.P. Fontella 221 (F, K, MO, RB n.v.); Gávea, 10 mar. 1971 (fl), K. Kubitzki 71-4 (M); Restinga do Recreio dos Bandeirantes, 29 fev. 1972 (fl), J.A. Jesus 1302 (K, RB n.v.); Via 11, próximo à Pedra de Itaúna, a mais ou menos 1 km, 14 jun. 1972 (fl), J.A. Jesus 1627 (K); Restinga de Sernambetiba, jun. 1977 (fl), P. Occhioni 8235 (MBM); Barra da Tijuca, km 8 da rodovia Rio-Santos, em direção a Grumari, 1 ago. 1977 (fl), L. Mautone et al. 114 (F, K, RB n.v.); Restinga da Barra da Tijuca, out. 1979 (fl), P.R.M. Nunes 225 (M); Pedra de Itaúna, 20 ago. 1980 (fl), M.B. Casari et al. 273 (B); Restinga de Jacarepaguá, Bosque da Barra, 26 set. 1982 (fl), M.H.O. Lemos 14 (HRB); Barra da Tijuca, km 15 a oeste da Barra da Tijuca na rodovia Rio-Santos, $23^{\circ} 2^{\prime}$ ' S e $43^{\circ} 26^{\prime} \mathrm{W}$, elev. 3-5 m, 26 fev. 1988 (fl, fr), W.W. Thomas et al. 6175 (MO, NY, SP, SPF); id. Bosque da Barra, 22 nov. 1993 (fl), M.L. Guedes et al. s.n. (ALCB 27921, SPF 118154). Rio das Ostras: entre Macaé e Rio das Ostras, 15 maio 1993 (fl), J.R. Pirani \& R. Mello-Silva 2877 (K, NY, MO, SP, SPF). Teresópolis: Vale dos Videiros, Morro do Cuca, elev. 1.500-1.700 m, 10 out. 1979 (fl), G. Martinelli \& O. Santos 6159 (F, K). Santa Catarina: 10 jul. 1885 (fl), M.A.Glaziou s.n. (G s.n.). Campo Alegre: Pinheiral, escarpas baixas do Morro Iquererim, elev. 1.000-1.300 m, 8 nov. 1956 (fl), L.B. Smith \& R. Klein 7360 (B); base do Morro do Iquererim, elev. 900-1.100 m, 9 dez. 1956 (fl), L.B. Smith \& R. Klein 8488 (NY); id., base do morro, elev. 1.300-1.500 m, 9-10 dez. 1956 (fl), L.B. Smith \& R. Klein 8513 (M); acima da fazenda de Ernesto Scheide, elev. 900-1.100 m, 1 fev. 1.957 (fl), L.B. Smith \& R. Klein 10574 (K); Morro do Iquererim, elev. 900 m, 5 set. 1.957 (fl), R. Reitz \& R. Klein 4801 (NY); Morro do Campo Alegre, elev. 1.300 m, 3 set. 1960 (fl), R. Reitz \& R.M. Klein 9758 (NY); Rodeio Grande, 17 jan. 1996 (fl), O.S. Ribas, E. Barbosa \& L.B.P. Silva 990 (MBM, G, W); serra Quiriri, Rio dos Alemães, elev. 1.400 m, 28 abr. 2001 (fl), O.S. Ribas, E. Barbosa \& P.E.R. Silva 3524 (MBM, G); id., elev. 1.300 m, 29 set. 2001 (fl), O.S. Ribas et al. 3673 (MBM). Lages: Campo dos Padres para Bom Retiro, 21 dez. 1948 (fl), R. Reitz 3706 (PACA); Parque das Pedras Brancas, $10 \mathrm{~km} \mathrm{SE} \mathrm{de} \mathrm{Lages,}$ 17 jan. 1988 (fl), A. Krapovickas \& C.L. Cristóbal 42046 (CTES n.v., K, MBM); id., 26 mar. 1998 (fl), R.S. Rodrigues 454 (ICN); id., 26 mar. 1998 (fl), R.S. Rodrigues 455 (ICN); id., 26 mar. 1998 (fl), R.S. Rodrigues 456 (ICN). Laguna: Campo d'Una, mar. 1889 (fl), E. Ule 1178 (P). São Joaquim: Serra do Oratório, rio Capivaras, 10 km de Bom Jardim da Serra, elev. ca. 1.200 m, 16 jan. 1957 (fl), L.B. Smith \& P.R. Reitz 10153
(MO, P). São Miguel: Campo de São Miguel, 10 jul. 1885 (fl), Schwacke s.n. (P).

Croton splendidus também está entre as espécies da seção Lamprocroton mais fáceis de serem reconhecidas e pode ser identificada, mesmo em estado vegetativo, por meio das folhas fortemente discolores, densamente distribuídas nos ramos, com nervura primária bastante marcada e face adaxial das folhas coberta por indumento tomentoso, formado por tricomas estrelados, com os raios laterais totalmente livres. O tipo de tricoma da face adaxial das folhas foi o principal caráter utilizado, por exemplo, por Mueller (1873), para separar C. migrans (=C. splendidus) de $C$. burchellii já que esta última apresenta a face adaxial das folhas lepidota. Croton uruguayensis e C. dichrous também podem ser diferenciadas de $C$. splendidus por conta da face adaxial das folhas, pois nos dois primeiros táxons essa região é, em geral, glabra (exceção pode ser encontrada em $C$. dichrous, mas, nesse caso, os tricomas que constituem o indumento da face adaxial das folhas são diferentes daqueles observados em C. splendidus). Em alguns poucos materiais examinados, o indumento da face adaxial das folhas é constituído por tricomas estrelado-lepidotos, com raios laterais unidos em aproximadamente 50\% da sua extensão total (por exemplo, em Ribas 379), porém essa característica não compromete a correta identificação do táxon, já que existem outros caracteres consistentes que podem ser utilizados. Em uma das coleções examinadas (Smith 10153) algumas folhas apresentam a face adaxial tomentosa, mas esse tipo de indumento era constituído por tricomas simples. Outras folhas do mesmo indivíduo, entretanto, possuíam a face adaxial das folhas coberta por tricomas estrelados. Deste modo, vale ressaltar que, apesar do indumento ser, muitas vezes, útil na identificação da espécie é um caráter que, algumas vezes, pode variar e outros caracteres devem ser levados em consideração para que a identificação possa ser feita de modo mais confiável.

Allem (1978), no seu trabalho preliminar sobre o gênero Croton em Santa Catarina, sinonimizou cinco espécies em C. migrans: C. ceanothifolius, $C$. pallidulus, C. chloroleucus, C. dusenii e C. confinis L.B. Smith \& Downs argumentando que essas entidades expressavam apenas variação no hábito de um único táxon, porém essa proposta não é aceita aqui. Quatro dessas espécies - C. ceanothifolius, C. chloroleucus, $C$. pallidulus e $C$. dusenii - são aqui reconhecidas como espécies válidas e pertencentes à seção Lamprocroton. Infelizmente, não foram vistos materiais de $C$. confinis, no entanto a análise do protólogo dessa espécie leva a crer que ela não seja um sinônimo de C. splendidus por não possuir glândulas na base da lâmina foliar.

24. Croton subcinerellus Croizat, Darwiniana 6: 462. 1944. Tipo: 'Paraguay, Sierra de Amambay, Pedro Juan Caballeros', [dez. 1933], Rojas 6543 (holótipo, A 47433!).

Croton subcinerellus var. aquidabanensis Croizat, Darwiniana 6: 463. 1944 Tipo: 'Paraguay. Inter Río Apa et Río Aquidabán', [1908-1909], Fiebrig 4560 (holótipo, A 47434!; isótipos, G!, K!, P!, W!). syn. nov.

Figuras 13g-j; $19 \mathrm{~b}$.

Arbustos, 1,0-1,2 m altura, monóicos; caule lepidoto, tricomas lepidoto-típicos, raios laterais parcialmente unidos (80-90\% do comprimento total), raio porrecto ausente, creme a dourados, sésseis. Folhas discolores, inteiras, cartáceas, lanceoladas, estreitamente oblongas a estreitamente elípticas, ápice agudo a acuminado, base aguda a arredondada, margem inteira, lâmina 1,0-4,5 cm comprimento, 0,2-0,9 cm largura, nervação broquidódroma, nervura primária impressa na face adaxial, saliente na abaxial, nervuras secundárias evidentes na face adaxial, pouco evidentes na abaxial, face adaxial lepidota, tricomas lepidototípicos, raios laterais parcialmente unidos (80-90\% do comprimento total), raio porrecto ausente, creme a dourados, curto-estipitados, face abaxial lepidota, tricomas lepidoto-típicos, raios laterais parcialmente unidos (80-90\% do comprimento total), raio porrecto ausente, creme, sésseis; pecíolos 1,5-3,0 mm comprimento Inflorescências racemos 
bissexuados, 1,0-3,0 cm comprimento, lepidotos, tricomas lepidototípicos, raios laterais parcialmente unidos (80-90\% do comprimento total), raio porrecto ausente, creme, sésseis; brácteas inteiras, persistentes, 3,0-4,0 mm comprimento, lineares, ápice acuminado, face abaxial lepidota, tricomas lepidoto-típicos, raios laterais parcialmente unidos (80-90\% do comprimento total), raio porrecto ausente, alvos a creme, curto-estipitados, face adaxial glabra. Flores estaminadas alvas a creme, ca. 3,0 mm comprimento; pedicelos 1,0-3,5 $\mathrm{mm}$ comprimento; sépalas 2,0-2,5 mm comprimento, cartáceas, largamente ovais, ápice acuminado, face abaxial lepidota, tricomas lepidoto-típicos, raios laterais parcialmente unidos (ca. $90 \%$ do comprimento total), raio porrecto ausente, creme, sésseis, face adaxial glabra; pétalas ca. 2,2 mm comprimento, membranáceas, estreitamente elípticas, ápice arredondado, ápice e metade distal da margem ciliados, tricomas simples, alvos, metade proximal da margem vilosa, tricomas simples, alvos, faces abaxial e adaxial glabras; estames 11, filetes ca. 2,0 mm comprimento, filiformes, pubescentes, tricomas simples, alvos, anteras ca. 1,0 mm comprimento, conectivos pubescentes, tricomas simples, alvos; receptáculo tomentoso, tricomas simples, alvos; disco 5-lobado. Flores pistiladas creme a douradas, ca. 0,9-1,1 cm comprimento; pedicelos ca. 1,0 mm comprimento; sépalas desiguais, três menores ca. 7,0 mm comprimento, duas maiores 9,0-11,0 mm comprimento, coriáceas, largamente ovais, ápice acuminado, face abaxial lepidota, tricomas dentado-lepidotos, raios laterais parcialmente unidos (ca. $70 \%$ do comprimento total), raio porrecto ausente, creme a dourados, sésseis, face adaxial tomentosa, tricomas estrelados, raio porrecto presente, alvos a creme, sésseis; pétalas presentes, reduzidas; disco inteiro; ovário lepidoto, tricomas dentado-lepidotos, raios laterais parcialmente unidos (ca. 70\% do comprimento total), raio porrecto ausente, creme a dourados, sésseis; estiletes bífidos, ramificados a partir da metade distal, lepidotos, tricomas dentado-lepidotos, raios laterais parcialmente unidos (ca. 70\% do comprimento total), raio porrecto ausente, alvos, sésseis; regiões estigmáticas 6, glabras. Frutos ca. $1,1 \mathrm{~cm}$ comprimento, ca. 8,0 mm largura; sementes ca. 4,0 mm comprimento, ca. 3,0 mm largura, elipsóides, testa castanha, lisa.

Distribuição geográfica e hábitats: Croton subcinerellus é endêmica do Paraguai (Croizat 1944), onde ocorre em regiões elevadas, serranas, como na Serra de Amambay e a Serra de Maracayú. Além das coleções-tipo, foram analisados apenas mais três materiais da espécie sendo que apenas um possuía indicação precisa de localidade, tendo sido coletado na província de Central.

Fenologia: Flores foram observadas em julho e outubro e frutos apenas em julho. Porém, vale ressaltar, que o número de coleções de $C$. subcinerellus presente nos herbários é extremamente pequeno e, talvez, por conta disso o período fenológico apresentado aqui não reflita o que realmente ocorre na natureza.

Material examinado: Paraguai: s.d. (fl), D.E. Hassler 126 (NY); s.d. (fl), D.E. Hassler 9366 (G); entre o rio Apa e o rio Aquidaban, 29 jul. 1910 (fl, fr), K. Fiebrig 4560 (K). Amambay: Sierra de Maracayú, s.d. (fl), Hassler 5126 (G, K, NY, P, W); Sierra de Amambay, s.d. (fl), Hassler 9866 (K, P). Central: de Nueva Ytalia a Tacuara, Granja Meili (antes Peter William), 5 out. 1987 (fl), E. Zardini \& R. Degen 3525 (MO).

Croton subcinerellus é uma espécie bastante semelhante, quanto ao tipo de indumento presente em toda a planta, a C. paraguayensis e C. cinerellus e em geral é confundida com esses dois táxons. Porém, na primeira as sépalas das flores pistiladas são largamente ovais e encobrem totalmente o gineceu sendo sempre muito maiores do que as das duas outras espécies. As folhas estreitas de C. subcinerellus, variando de lanceoladas, estreitamente oblongas a estreitamente elípticas são outro caráter que pode auxiliar na distinção entre esses táxons. Segundo Croizat (1944) o indumento de C. cinerellus é mais metálico do que aquele presente em C. subcinerellus, entretanto essa característica é variável e de difícil utilização para a distinção entre essas espécies. Já a distribuição geográfica constitui bom subsídio para a identificação, pois enquanto a primeira é uma espécie exclusivamente brasileira que ocorre em São Paulo, Mato Grosso e Mato Grosso do Sul, em regiões de cerrado e cerradão, a segunda é endêmica do Paraguai, onde ocorre em regiões serranas. Em contrapartida, C. subcinerellus e $C$. paraguayensis são ambas as espécies exclusivamente paraguaias e que ocorrem nos mesmos tipos de ambientes; no entanto, as flores pistiladas podem facilmente utilizadas para distingui-las, pois além da forma das sépalas, o tipo de ramificação dos estiletes é diferente nessas espécies sendo, em geral, apenas uma vez bífidos naquela e sempre duas vezes bífidos nesta.

Croizat (1944), em seu trabalho sobre novas espécies de Croton na América do Sul, optou por não classificar essa espécie em nenhuma das seções propostas por Mueller (1866, 1873), alegando que isso não era uma tarefa simples e que uma evidência desse fato pode ser vista no trabalho de Léandri (1939) no qual o autor, trabalhando com o gênero Croton em Madagáscar, preferiu agrupar as espécies dessa região em "grupos", ou seja, em uma categoria informal e não taxonômica. Entretanto, apesar de C. subcinerellus não ter sido previamente classificada, nem por Croizat (1944), nem por Webster (1993), em alguma categoria infragenérica, essa espécie possui as características típicas dos representantes da seção Lamprocroton, como hábito arbustivo bastante ramificado, indumento lepidoto em diversas partes, número de estames e tipo de ramificação dos estiletes deste modo, ela foi aqui tratada como um representante desta seção.

25. Croton tenellus Müll. Arg. in Mart. \& Eichl., Fl. bras. 11 (2): 248.1873. Tipo: Brasil, Minas Gerais, 'ad Pirés', Martius s.n. (holótipo, G!; isótipo, M 0089121!; fotografia do isótipo, NY! ex M).

Figuras 14a-b; 19c.

Arbustos, ca. 50,0 cm altura, monóicos; caule lepidoto, tricomas lepidoto-típicos, raios laterais parcialmente unidos (ca. 90\% do comprimento total), raio porrecto ausente, creme a dourados, sésseis a curto-estipitados. Folhas fortemente discolores, inteiras, cartáceas, elípticas, ápice obtuso, base aguda, margem inteira, lâmina 4,0-8,0 mm comprimento, 2,0-3,0 mm largura, nervação hifódroma, impressa na face adaxial, saliente na abaxial, face adaxial tomentosa, tricomas estrelados, raio porrecto presente, alvos a creme, sésseis, face abaxial lepidota, tricomas lepidoto-típicos, raios laterais parcialmente unidos (ca. 95\% do comprimento total), raio porrecto ausente, creme a dourados, sésseis; pecíolos ca. 1,0 mm comprimento Inflorescências racemos bissexuados, ca. 1,2 cm comprimento, lepidotos, tricomas lepidoto-típicos, raios laterais parcialmente unidos (ca. $90 \%$ do comprimento total), raio porrecto ausente, creme a dourados, sésseis a curto-estipitados; brácteas inteiras, persistentes, ca. 0,5 mm comprimento, lanceoladas, ápice agudo, face abaxial lepidota, tricomas lepidoto-típicos, raios laterais parcialmente unidos (ca. $90 \%$ do comprimento total), raio porrecto ausente, creme a dourados, sésseis a curto-estipitados, face adaxial glabra. Flores estaminadas não observadas. Flores pistiladas creme, ca. 2,0 mm comprimento; pedicelos ca. 1,5 mm comprimento; sépalas iguais, ca. 2,0 mm comprimento, coriáceas, espatuladas, ápice agudo, face abaxial lepidota, tricomas lepidoto-típicos, raios laterais parcialmente unidos (ca. 95\% do comprimento total), raio porrecto ausente, creme a dourados, sésseis, face adaxial tomentosa, tricomas estrelados, raio porrecto presente, alvos a creme, sésseis; pétalas ausentes; disco não observado; estiletes não observados; regiões estigmáticas não observadas. Frutos não observados.

Distribuição geográfica e hábitats: Croton tenellus foi coletada apenas uma vez, no estado de Minas Gerais, sendo a espécie conhecida apenas dessa coleção-tipo. Nem o protólogo e nem a etiqueta do holótipo possuem informações acerca do tipo de ambiente em que a espécie ocorre. Sendo grande o esforço de coleta nesse estado pode-se temer que $C$. tenellus trate-se, provavelmente, de um táxon extinto. 
Fenologia: Não foi possível apresentar o período fenológico de $C$. tenellus já que foi analisada apenas a coleção-tipo que não apresentava data de coleta na etiqueta da exsicata.

A descrição de $C$. tenellus está bastante incompleta porque, além de ser baseada apenas no espécime-tipo, as flores estaminadas ainda se encontram em estádio de botão e a única flor pistilada examinada estava mal preservada e não possuía gineceu e nem disco nectarífero. Nesta coleção também não há frutos. Apesar disso, C. tenellus é uma espécie de fácil reconhecimento utilizando-se apenas o hábito, pois possui folhas relativamente pequenas, fortemente discolores, com face adaxial tomentosa, coberta por tricomas estrelados e face abaxial lepidota, com indumento formado por tricomas lepidoto-típicos cujos raios laterais são quase que completamente unidos.

Croton tenellus foi descrita por Mueller (1873) e o autor também não apresenta, no protólogo, informações acerca das flores estaminadas e dos frutos, entretanto diz que o ovário é lepidoto e que os estiletes são apenas uma vez bífidos. Apesar de Mueller (1873) classificar esse táxon como um representante da seção Decarinium, grupo que apresenta as sépalas das flores pistiladas desiguais, no material aqui examinado não se percebeu uma diferença evidente no tamanho ou forma das sépalas das flores pistiladas. De acordo com o autor (Mueller 1873) trata-se de uma espécie morfologicamente semelhante a $C$. migrans $(=C$. splendidus $)$, porém a forma e o tamanho das folhas é diferente entre esses dois táxons. Além disso, C. tenellus possui o hábito mais ramificado e as folhas mais densamente dispostas nos ramos e, enquanto em $C$. splendidus as sépalas das flores pistiladas variam de obovais a largamente espatuladas, em $C$. tenellus elas são espatuladas.

26. Croton uruguayensis Baill., Adansonia 4: 292. 1864. Tipo: 'Banda oriental del Uruguay', [1816-1821], Saint-Hilaire C2-2449 (lectótipo, P!). Síntipo excluído: [Uruguai], 'Banda oriental del Uruguay', [1816-1821], SaintHilaire $\mathrm{C} 2-2249(\mathrm{P})=$ Heliotropium $\mathrm{sp}$.

Croton gaudichaudii Baill., Adansonia 4: 293. 1864. Tipo: [Brasil], [Rio Grande do Sul], [1833], Gaudichaud 1672 (lectótipo, P!; fotografias do lectótipo, MO!). Remanescentes dos síntipos originais: [Brasil], 'Prov. de Rio-Grande', s.d., Saint-Hilaire C2-2525 (P!). [Brasil], [Rio Grande do Sul], [1833], Gaudichaud 1667 (P!).

Croton minutiflorus Müll. Arg., Linnaea 34: 138. 1865. Tipo: 'In Brasilia meridionali', s.d., Sellow s.n. (holótipo, B†).

Figuras 14c-h; 19d.

Nomes populares: "velame-de-gaudichaud" (Smith et al. 1988); "sarandí-blanco" (Schinini 4893); "sarandisillo" (Montes 27578).

Subarbustos a arbustos, 0,5-4,0 m altura, monóicos; caule lepidoto, tricomas lepidoto-típicos, raios laterais parcialmente unidos (ca. 90\% do comprimento total), raio porrecto presente, creme a dourados, sésseis. Folhas fortemente discolores, inteiras, cartáceas, ovais a lanceoladas, ápice agudo a acuminado, mucronulado, base aguda, margem inteira, lâmina 2,1-4,6 cm comprimento, 0,5-1,2 cm largura, nervação broquidódroma, nervura primária impressa na face adaxial, saliente na abaxial, nervuras secundárias pouco evidentes na face adaxial, salientes na abaxial, face adaxial glabra, face abaxial lepidota, tricomas lepidoto-típicos, raios laterais parcialmente unidos (ca. $90 \%$ do comprimento total), raio porrecto presente, creme, cinéreos a dourados, sésseis; pecíolos 2,0-7,0 mm comprimento Inflorescências racemos unissexuados, 1,5-7,5 cm comprimento, lepidotos, tricomas lepidoto-típicos, raios laterais parcialmente unidos (ca. 90\% do comprimento total), raio porrecto presente, creme a dourados, sésseis; brácteas inteiras, persistentes, 1,0-3,5 mm comprimento, triangulares a estreitamente triangulares, ápice agudo a acuminado, face abaxial lepidota, tricomas lepidoto-típicos, raios laterais parcialmente unidos (ca. $90 \%$ do comprimento total), raio porrecto presente, creme a dourados, sésseis, face adaxial glabra. Flores estaminadas alvas, creme a amareladas, 1,5-3,0 mm comprimento; pedicelos 1,5-2,5 $\mathrm{mm}$ comprimento; sépalas 1,5-2,0 mm comprimento, subcoriáceas, ovais a triangulares, ápice agudo, face abaxial lepidota, tricomas lepidototípicos, raios laterais parcialmente unidos (ca. $90 \%$ do comprimento total), raio porrecto presente, creme a dourados, sésseis, face adaxial glabra; pétalas 1,8-3,0 mm comprimento, membranáceas, espatuladas a estreitamente elípticas, ápice agudo a arredondado, ápice e metade distal da margem ciliados, tricomas simples, alvos, metade proximal da margem vilosa, tricomas simples, alvos, face abaxial lepidota, tricomas lepidoto-típicos, raios laterais parcialmente unidos (ca. 90\% do comprimento total), raio porrecto presente, alvos a creme, sésseis, face adaxial glabra; estames 10-12, filetes 1,5-2,0 mm comprimento, filiformes, glabros, anteras $0,5-0,8 \mathrm{~mm}$ comprimento, conectivos glabros; receptáculo tomentoso, tricomas simples, alvos; disco 5-lobado. Flores pistiladas creme a esverdeadas, 2,0-3,0 mm comprimento; pedicelos 1,5-2,0 mm comprimento; sépalas desiguais, duas menores, 1,5-2,5 mm comprimento, três maiores, 2,0-2,8 $\mathrm{mm}$ comprimento, coriáceas, oblongas a estreitamente oblongas, ápice acuminado, face abaxial lepidota, tricomas lepidoto-típicos, raios laterais parcialmente unidos (ca. $90 \%$ do comprimento total), raio porrecto presente, creme a dourados, sésseis, metade distal da face adaxial tomentosa, tricomas estrelados, raio porrecto presente, creme a alvos, sésseis; pétalas presentes, reduzidas; disco 5-lobado; ovário lepidoto, tricomas lepidoto-típicos, raios laterais parcialmente unidos (ca. 90\% do comprimento total), raio porrecto presente, dourados, sésseis; estiletes bífidos, ramificados desde a base, glabros; regiões estigmáticas 6, glabras. Frutos 4,0-5,0 mm comprimento, 3,5-4,0 mm largura; sementes 2,0-3,0 mm comprimento, 1,5-2,0 mm largura, elipsóides, testa castanha a castanho-alaranjada, lisa.

Distribuição geográfica e hábitats: Croton uruguayensis ocorre, no Brasil, exclusivamente na região Sul, nos três estados dessa região: Paraná, Santa Catarina e Rio Grande do Sul. Segundo Smith et al. (1988) trata-se de uma espécie muito rara em Santa Catarina, encontrada nos campos úmidos ou na margem de rios e regatos. Além do Brasil, ocorre na Argentina, Uruguai e Paraguai. Há apenas um registro de $C$. uruguayensis feito na Bolívia, proveniente de uma região com altitude de cerca de $2.000 \mathrm{~m}$. Em geral, está associada a lugares úmidos como matas ciliares e margem de rios, mas pode também ser encontrada em áreas de campo e capoeira, geralmente, em terrenos arenosos. É encontrada também, com menos freqüência, em mata costeira e áreas de pastagem com baixa drenagem.

Fenologia: Flores foram encontradas praticamente durante todo o ano, com exceção dos meses de junho e dezembro. Frutos foram observados de janeiro a março e em setembro e novembro.

Material examinado: Argentina: 7 mar. 1945 (fl), Bertoni 819 (NY). Corrientes: Concepción: 1877 (fl), P.G. Lorentz s.n (F 3919). Monte Caseros: $8 \mathrm{~km}$ ao sul de Labougle, margem do rio Uruguai, 22 fev. 1979 (fl), A. Schinini, E. Cabral \& R. Vanni 17559 (CTES, ICN, MO); campo General Avalos, Paso de la Barca, sobre o rio Miriñay, 11 set. 1979 (fl), A. Schinini, S.J. Tressens \& R. Vanni 18770 (CTES, ICN, K). Paso de los Libres: Paso de los Libres, 10 jan. 1945 (fl), C. Fbarrola 2020 (LIL n.v., NY); Laguna Mansa, 19 fev. 1972 (fl), A. Krapovickas \& C.L. Cristobal 21681 (P); próximo da Ponte Internacional, 20 set. 1973 (fl), A. Schinini, C.L. Cristóbal \& R. Carnevali 7194 (CTES, RB); estância El Recreo, $21 \mathrm{~km}$ a leste de Bonpland, margem do rio Uruguai, 18 nov. 1973 (fl), A. Lourteig, A. Schinini \& V. Maruñak 2771 (CTES, G, MBM, P); Paso Troncón, 8 dez. 1978 (fl), A. Krapovickas \& C.L. Cristóbal 34243 (CTES, MO). San Martín: La Cruz, 18 jul. 1944 (fl), C. Ibarrola 1732 (LIL n.v., NY, W); Yapeyú, 28 jan. 1976 (fl), A. Krapovickas \& C.L. Cristóbal 28994 (CTES); $5 \mathrm{~km}$ a leste de Guaviraví, na estrada vicinal, na margem do rio Uruguai, 13 fev. 1979 (fl), O. Ahumada 2871 (CTES, MO); costa do rio Uruguai, 14 set. 1979 (fl), A. Schinini, S.G. Tressens \& R. Vanni 18390 (CTES, K, MO). Santo Tomé: estância Garruchos, no arroio 
Garabí, 10 out. 1969 (fl), T.M. Pedersen 9243 (CTES, MBM, P); Rota 40, $20 \mathrm{~km}$ a sudoeste de Garruchos, 23 abr. 1975 (fl), R. Carnevali 3561 (CTES); arroio Chimiray, 2 km a leste da Rota 40, 2 fev. 1976 (fl), A. Krapovickas \& C.L. Cristóbal 29129 (CTES, MO); estância Timbó, arroio Ciriaco e Rota 40, 27 fev. 1983 (fl), A. Schinini et al. 23497 (CTES, F, MBM, WIS). Entre Rios: arroio Chancho, 25 maio 1880 (fl), P.G. Lorentz s.n. (MO 2020530). Concepcion del Uruguay: abr. 1875 (fl), P.G. Lorentz s.n. (W 3382); out. 1875 (fl), P.G. Lorentz. s.n. (W 3384); out. 1877 (fl), P.G. Lorentz 1151 (G, K, M, P, W); 1 maio 1880 (fl), P.G. Lorentz s.n. (MO 2020529); 14 jan. 1945 (fl), C. Lehulz 333 (LIL n.v., NY); nov. 1921 (fl), Hauman s.n. (CTES 38073). Colón: 12 fev. 1931 (fl), Castellanos s.n. (CTES 31/1117); ilha São José, nov. 1976 (fl, fr), N.S. Troncoso et al. 1022 (MBM, SI n.v.). Concordia: E.R. Puerto Yeruá, 20 dez. 1923 a 5 jan. 1924 (fl), Pennington s.n. (CTES 38140); arroio Ajuí Grande, 19 dez. 1957 (fl), T.M. Pedersen 4775 (MBM); San Carlos, jan. 1967 (fl), R.M. Crovetto \& Grondona 4176 (CTES, SPF). Federacion: rio Uruguai, jan. 1948 (fl), R.M. Crovetto \& Piccinini 4685 (CTES, MO); estância La Matilde, 23 nov. 1976 (fl), N.S. Troncoso et al. 1336 (CTES); arroio Madisoví, Rota 14, 29 set. 1978 (fl, fr), O. Bottino 52 (CTES). La Paz: arroio San Loreyo, 27 nov. 1934 (fl, fr), A.L. Cabrera 3254 (NY); isla Curuzú, 16 dez. 1963 (fl), A. Burkart 24840 (MO). Mendoza: General Alvear: Rota 40 e rio Aguapey, 20 nov. 1973 (fl), A. Lourteig, A. Schinini \& V. Maruñak 2835 (CTES, P); id., 7 fev. 1979 (fl), A. Schinini, E. Cabral \& R. Vanni 16796 (CTES, MO, WIS). Misiones: Campo Grande: jan. 1957 (fl), R.M. Crovetto 8716 (CTES). Candelaria: Garupa, 15 out. 1945 (fl), Bertoni 2218 (K, LIL n.v.); Rota 204, entre a Rota 12 e Profundidad, 29 set. 1972 (fl), A. Schinini 5410 (CTES, MBM, MO, NY, P). Posadas: Alto Paraná, 2 dez. 1907 (fl), E.L. Ekman 457 (G, NY); San Ignacio, 14 jan. 1908 (fl), E.L. Ekman 458 (F, K, MO); 25 set. 1909 (fl), Rodriguez 65 (LIL n.v., NY); 2-10 out. 1911 (fl), A.S. Muniz 58 (G); set. 1947 (fl), E. Grondona \& R. Spezazzini 1275 (CTES); elev. 110 m, 2 nov. 1949 (fl), Bertoni 4783 (LIL, K, NY, WIS); Rota 12, arroio Zaimán, 20 set. 1969 (fl), A. Krapovickas, C.L. Cristóbal \& V. Maruñak 15431 (MBM, MO, NY, P); Mercado de La Plazita, 14 jul. 1972 (fl), A. Schinini 4893 (CTES, P, WIS); arroio Zaimán, 7 out. 1972 (fl), T. Insaurralde 1112 (CTES); id., $27^{\circ} 25^{\prime}$ 6,3" S e 55 53' 53,2" W, elev. 90 m, 13 fev. 2004 (fl, fr), L.R. Lima, M.A. Farinaccio \& A.B. Junqueira 337 (SP, SPF, WIS). San Ignacio: arroio Yabebiry, 26 set. 1945 (fl, fr), J.G. Schwarz 1297 (LIL n.v., P, W); Corpus, elev. 220 m, 19 set. 1946 (fl), G.J. Schwarz, 3401 (LIL n.v., NY); Santo Pipó, 25 ago. 1947 (fl), G.J. Schwartz 4738 (LIL, MO); Oasis, 12 ago. 1950 (fl), G.J. Schwarz 10548 (LIL n.v., W); Nacanguasú, próximo do rio Paraná, elev. 290 m, 27 mar. 1958 (fl), A.J.E. Montes 27758 (NY). San Pedro: Campo Cumprido, 27 set. 1945 (fl), Bertoni 2156 (LIL n.v., W). Bolívia: Santa Cruz: San Ignacio de Velasco: elev. 2.000 m, jul. 1892 (fl), O. Kuntze s.n. (NY s.n.). Brasil: s.d. (fl), Sellow 3488 (B n.v., NY); 13 nov. 1907 (fl), Sellow s.n. (P); Brasil meridional, s.d. (fl, fr), Sellow s.n. (G 5335). Paraná: Capitão Marques, margem do rio Iguaçu, $25^{\circ} 30^{\prime} \mathrm{S}$ e $53^{\circ} 40^{\prime} \mathrm{W}$, 21 mar. 1993 (fl), S.M. Silva s.n. (NY 00504104, UPCB 20579). Dois Vizinhos: Fazenda do Chopim, 9 dez. 1968 (fl), G. Hatschbach \& O. Guimarães 20578 (MBM, MO). Guarapuava: fazenda Reserva, $85 \mathrm{~km}$ a sudoeste de Guarapuava, nos bancos do rio Reserva, 18 mar. 1967 (fl), J.C. Lindeman \& J.H. Haas 5019 (B, K, NY). Rio Grande do Sul: s.d. (fl), B. Rambo s.n. (PACA 4293). Bagé: Passo do Viola, 27 mar. 1984 (fl, fr), A.M. Girardi-Deiro \& J.O.N. Gonçalves 599 (CNPO n.v., MBM). Cambará do Sul: Cambará para São Franciso de Paula, fev. 1948 (fl), B. Rambo s.n. (B, PACA 36210); cânion Fortaleza, 28 out. 1997 (fl), R.S. Rodrigues 484 (ICN). Jaquirana: Jaquirana para São Francisco de Paula, 20 fev. 1952 (fl), B. Rambo s.n. (B, PACA 52027). Manoel Viana: 12 set. 1993 (fl), R.A. Záchia 1424 (HAS n.v., MBM). Quaraí: Cerro do Jarau, nov. 1973 (fl),
B. Irgang et al. s.n. (ICN 26922). São José dos Ausentes: 12 km após São José dos Ausentes, em direção a Bom Retiro, 28 out. 1997 (fl), R.S. Rodrigues 491 (ICN); Serra da Rocinha, elev. 1.100 m, 18 mar. 2002 (fl), R. Wasum 1418 (HUCS). Santa Catarina: Lages: 1935 (fl), A. Bruxel s.n. (PACA 6806); Vacas Gordas, elev. 900 m, 14 set. 1963 (fl), R. Reitz \& R.M. Klein 16307 (RB). São Joaquim: Morro da Igreja para São Joaquim, 3 jan. 1949 (fl), R. Reitz 3637 (PACA); 10 fev. 1958 (fl), J. Mattos 5831 (PACA). Urubici: Serra do Corvo Branco, nov. 1995 (fl), M. Sobral et al. 8116 (MBM). Paraguai: jan. 1875 (fl, fr), B. Balansa 1650 (K, P); 1888-1890 (fl, fr), T. Morong 518 (K, MO, NY); 1909-1910 (fl), K. Fiebrig 5385 (K). Caazaápa: Yuty: $15 \mathrm{~km}$ ao sul de Capitindy, 1 set. 1987 (fl), M.M. Arbo, A. Schinini \& I. Basualdo 2854 (CTES, G, MO); Dstrito Yuty, desvio a Tres de Mayo, Companhia Capitindy, 10 set. 1987 (fl, fr), E. Zardini, I. Basualdo \& N. Soria 2935 (MO). Guairá: Tebicuary: Azucarera de Terbicuary, s.d. (fl), P. Jorgensen 1328 (NY); arroio Yhacá, 12 jan. 1973 (fl), A. Schinini 5846 (CTES, G, MO, NY, P). Uruguai: jul. 1868 (fl), M.E. Gubert 262 (K). Rocha: Rocha: Paso de Averias, rio Cebrollati, 29 nov. 1937 (fl), Roseugurt B 2332 (F). Florida: Florida: estância Rincón de Santa Elena, rio Yí, entre os arroios Timote e Mansavillagra, 22 abr. 1943 (fl), R. Gallinal et al. PE-5214 (MO, NY); id., Picada Castro, arroio Mansavillagra, out. 1946 (fl), R. Gallinal 5721 (MO). Salto: Salto: 4 out. 1978 (fl), S.A. Renvoize 2896 (K). Soriano: Mercedes: rio Negro, próximo de Mercedes, 1867 (fl), M. Fruchard 11262 (P). Tacuarembó: Tacuarembó: Tacuarembó Grande, 19 jan. 1994 (fl), T.M. Pedersen 15893 (CTES, G). Treinta y Tres: Vergara: dez. 1932 (fl), W.G. Verter 849 (NY); 22 dez. 1933 (fl), W.G. Verter 1604 (F, M, MO); abr. 1935 (fl), C.D. Legrand 554 (F).

As folhas fortemente discolores, com face adaxial glabra e face abaxial densamente lepidota são as características mais facilmente utilizadas para o reconhecimento de $C$. uruguayensis. Aliadas a elas estão as longas inflorescências unissexuadas e a distribuição geográfica, uma vez que a espécie ocorre apenas na região Sul do Brasil e nos países mais meridionais da América do Sul, como Argentina, Paraguai e Uruguai. Apesar da maioria dos espécimes analisados possuir a face adaxial das folhas completamente glabra, em alguns exemplares pôdese notar a presença de tricomas lepidotos, com raios laterais quase que completamente unidos, esparsamente distribuídos nessa região da planta ou, especialmente, na margem foliar e na região das nervuras. Tal fato foi observado, por exemplo, nas coleções Hatschbach 20578, Krapovickas 29129e Sehem 2139. Quando isso ocorre, C. uruguayensis torna-se muito semelhante a $C$. myrianthus, porém as inflorescências da primeira são sempre maiores e mais delicadas do que as observadas na segunda. Apesar de C. muellerianus L.R. Lima também apresentar folhas com face adaxial glabra e abaxial lepidota dificilmente essa espécie é confundida com C. uruguayensis, pois a forma e o tamanho das folhas, bem como o tamanho e o tipo das inflorescências são bastante distintos entre essas duas espécies. Em C. muellerianus as folhas são menores e mais largas (1,2-3,6 cm comprimento x 0,9-2,3 cm largura), em geral, elípticas, largamente elípticas a largamente ovais e as inflorescências são bissexuadas, também menores, com comprimento variando de 1,0 a 2,6 cm. Em contrapartida, C. uruguayensis possui folhas ovais a lanceoladas, variando de 2,1 a $4,6 \mathrm{~cm}$ de comprimento e 0,5 a $1,2 \mathrm{~cm}$ de largura e as inflorescências são unissexuadas com 1,5 a 7,5 cm de comprimento.

Smith et al. (1988) citaram a presença de inflorescências bissexuadas em $C$. uruguayensis, porém todos os materiais aqui analisados apresentam apenas um tipo de flor na inflorescência. Talvez, as inflorescências sejam apenas funcionalmente unissexuadas já que em grande parte das espécies de Croton, ocorre protoginia, isto é, as flores pistiladas desenvolvem-se antes das estaminadas. No entanto, preferiu-se aqui descrever as inflorescências como unissexuadas já que esse foi o padrão observado nos indivíduos estudados. 


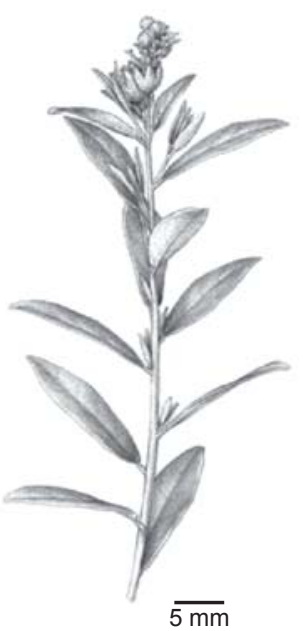

(a)

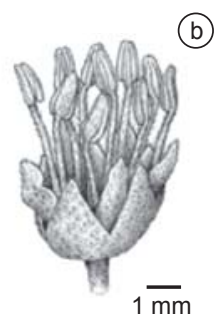

(b)
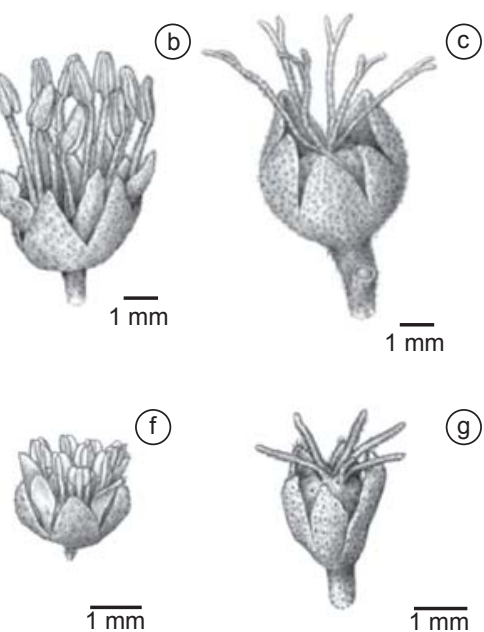

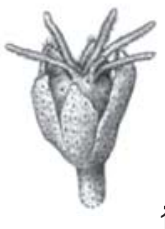

(9)

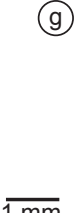

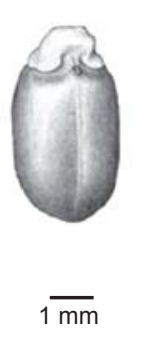

(n)

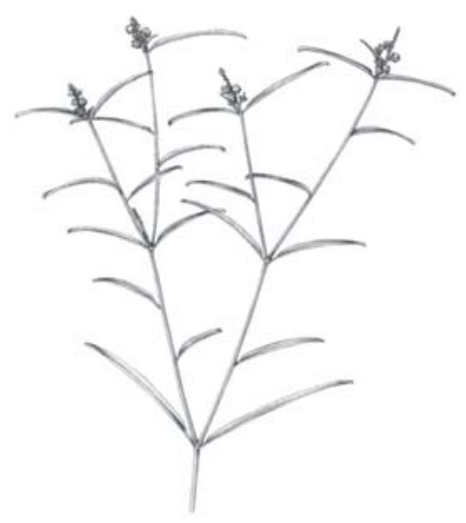

$\overline{2 \mathrm{~cm}}$
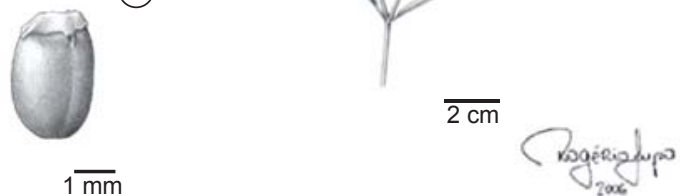

Figura 1. a-d) Croton argentinus: a) hábito; b) flor estaminada; c) flor pistilada; d) semente. e-h) Croton burchellii: e) hábito; f) flor estaminada; g) flor pistilada; e h) semente. (a-d) Lorentz 65; e e-h) Eiten 4562).

Figure 1. a-d) Croton argentinus: a) habit; b) staminate flower; c) pistillate flower; d) seed. e-h) Croton burchellii: e) habit; f) staminate flower; g) pistillate flower; and h) seed. (a-d) Lorentz 65; and e-h) Eiten 4562).

(a)

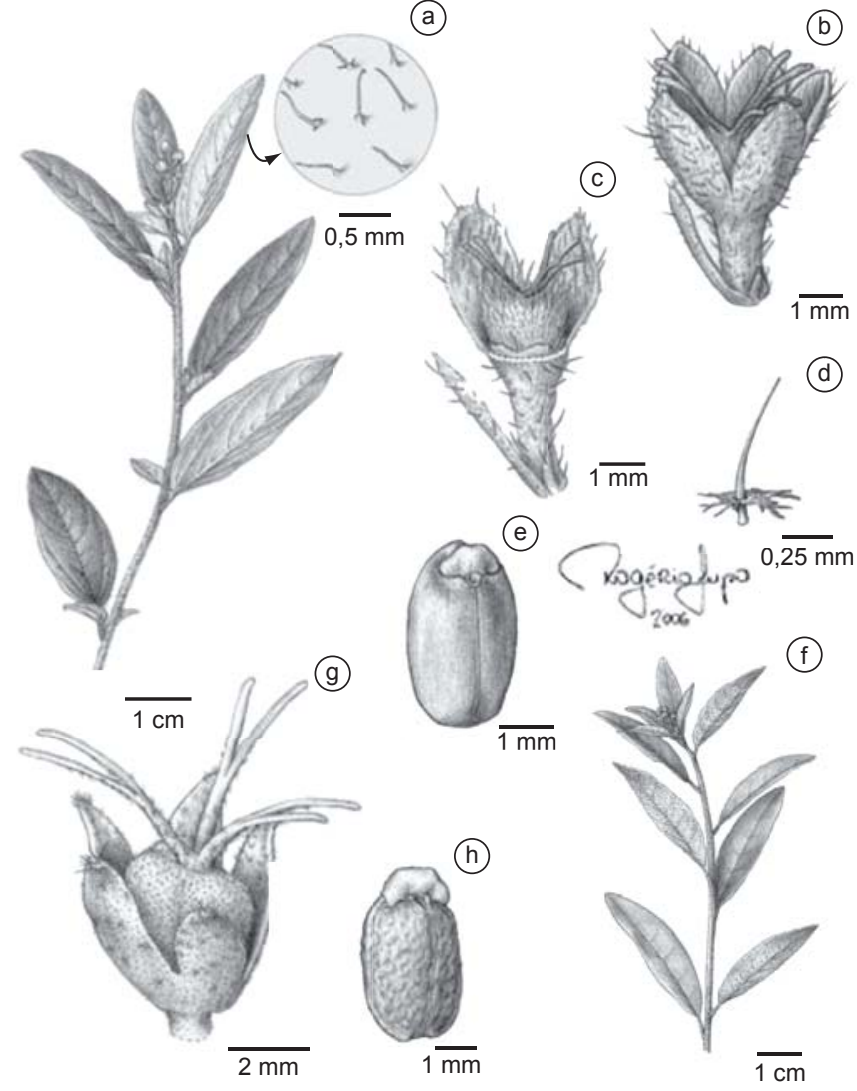

Figura 2. a-e) Croton ceanothifolius: a) hábito e detalhe dos tricomas simples da face adaxial das folhas; b) flor pistilada inteira; c) flor pistilada sem três sépalas; d) tricoma da face abaxial das folhas; e) semente. f-h) Croton chloroleucus: f) hábito; g) flor pistilada; e h) semente. (a-d) Lima 352; b-c) Brandão s.n. OUPR 3693; Magalhães 1105; e f-h) Krapovickas 38371).

Figure 2. a-e) Croton ceanothifolius: a) habit and simple trichomes of adaxial leaves surface in detail; b) entire pistillate flower; c) staminate flower without three sepals; d) trichome of abaxial leaves surface; e) seed. f-h) Croton chloroleucus: f) habit; g) pistillate flower; and h) seed. (a-d) Lima 352; b-c) Brandão s.n. OUPR 3693; Magalhães 1105; and f-h) Krapovickas 38371).
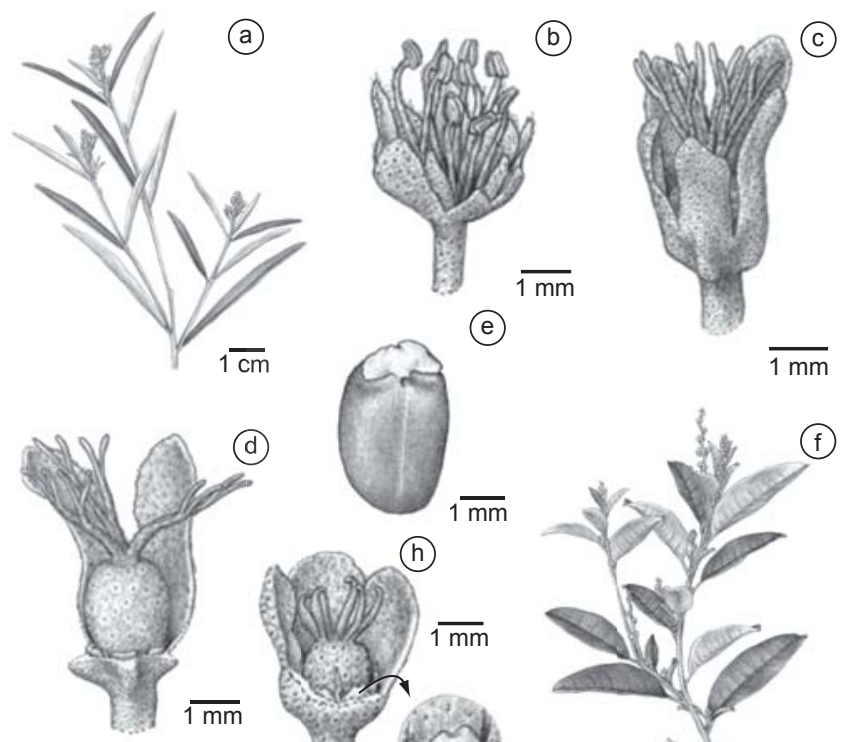

(d)
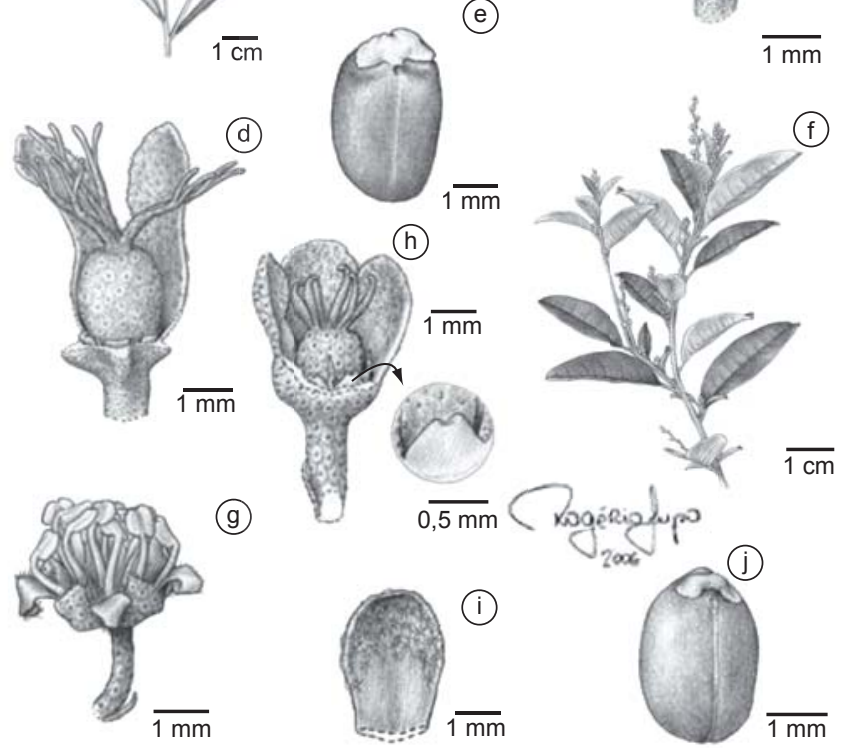

(9)
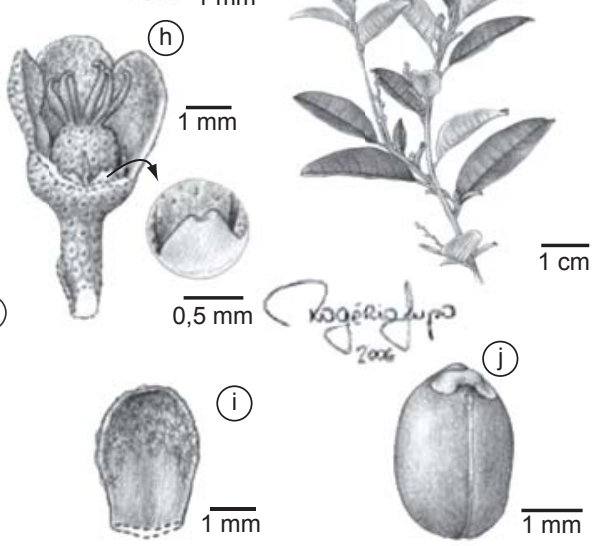

Figura 3. a-e) Croton cinerellus: a) hábito; b) flor estaminada; c) flor pistilada inteira; d) flor pistilada sem três sépalas; e) semente. f-j) Croton dichrous: f) hábito; g) flor estaminada; h) flor pistilada sem duas sépalas e detalhe do disco nectarífero; i) sépala da flor pistilada em vista adaxial; e j) semente. (a-e) Regnell s.n. F 575572; e f-j) Cordeiro 2771).

Figure 3. a-e) Croton cinerellus: a) habit; b) staminate flower; c) entire pistillate flower; d) pistillate flower without three sepals; e) seed. f-j) Croton dichrous: f) habit; g) staminate flower; h) pistillate flower without two sepals and nectarifer disk in detail; i) pistillate flower sepal in adaxial view; and j) seed. (a-e) Regnell s.n. F 575572; and f-j) Cordeiro 2771).

http://www.biotaneotropica.org.br/v8n2/pt/abstract?taxonomic-review+bn01108022008 

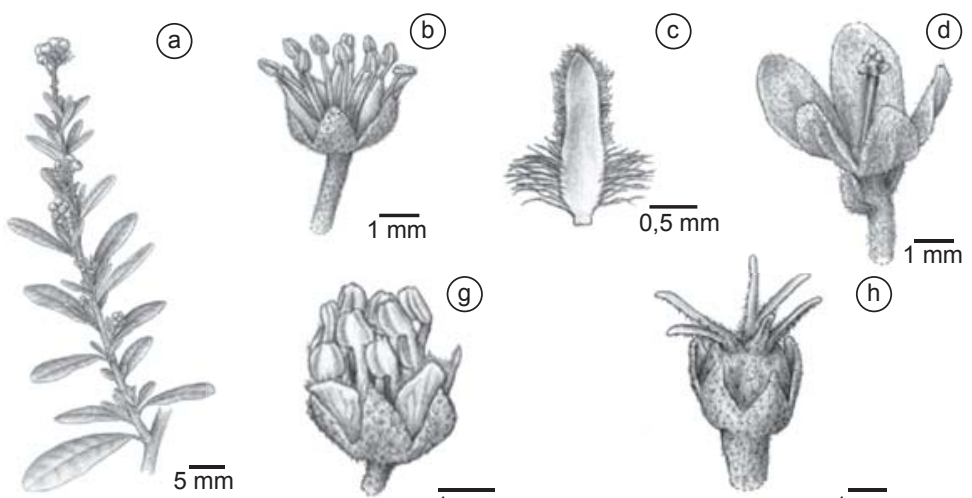

(d)
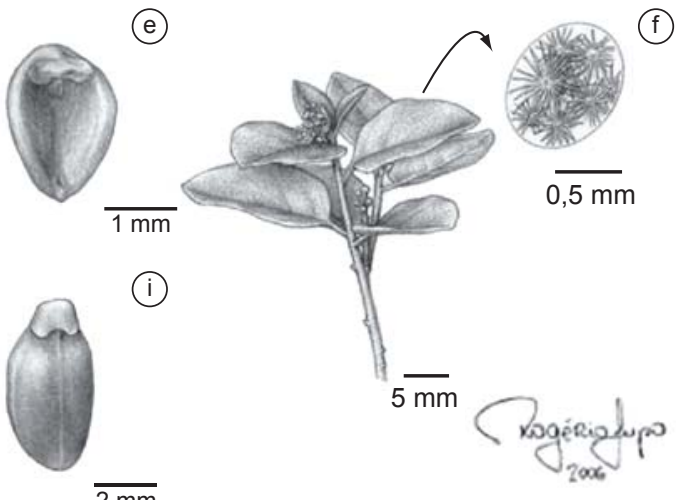

(†
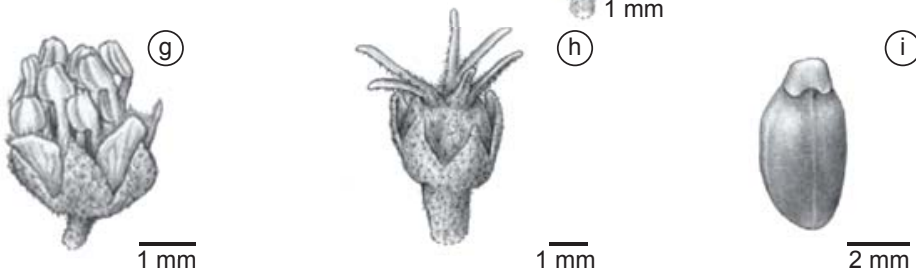

Figura 4. a-e) Croton dusenii: a) hábito; b) flor estaminada; c) pétala da flor estaminada em vista abaxial; d) resquício do cálice da flor pistilada com columela; e) semente. f-i) Croton ehrenbergii: f) hábito e detalhe do indumento da face adaxial das folhas; g) flor estaminada; h) flor pistilada; e i) semente. (a, d) Lima 355; b, c) Reitz 13779; e) Dombrovski 3252; f-h, i) Vilchis 226; e g) Hernandez 3308).

Figure 4. a-e) Croton dusenii: a) habit; b) staminate flower; c) staminate flower petal in abaxial view; d) residue pistillate flower sepals and column; e) seed. f-i) Croton ehrenbergii: f) habit and indumentum of adaxial leaves surface in detail; g) staminate flower; h) pistillate flower; and i) seed. (a, d) Lima 355; b-c) Reitz 13779; e) Dombrovski 3252; f-h, i) Vilchis 226; and g) Hernandez 3308).

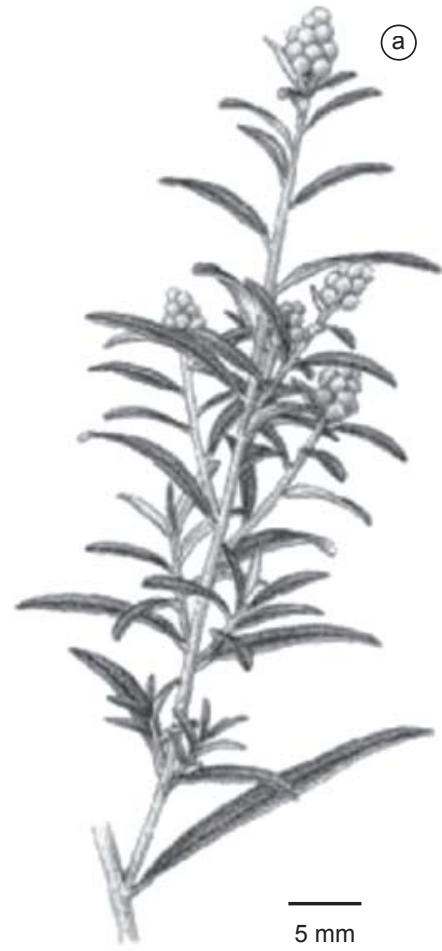

(I)

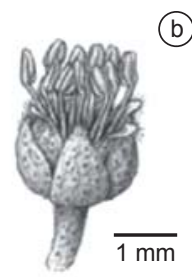

$(\uparrow$
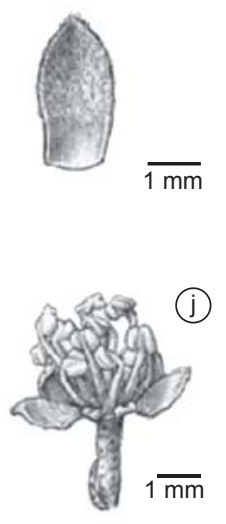

(n)

() (b)

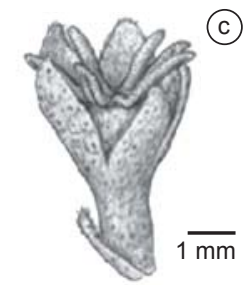

(9)

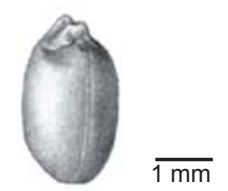

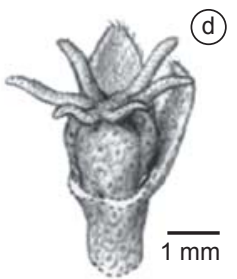

(d)

(e)

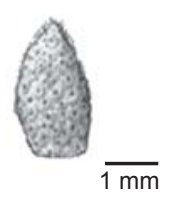


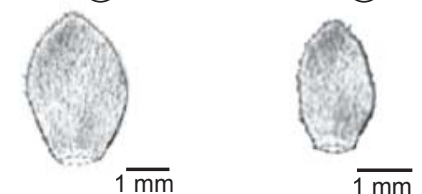

(P)
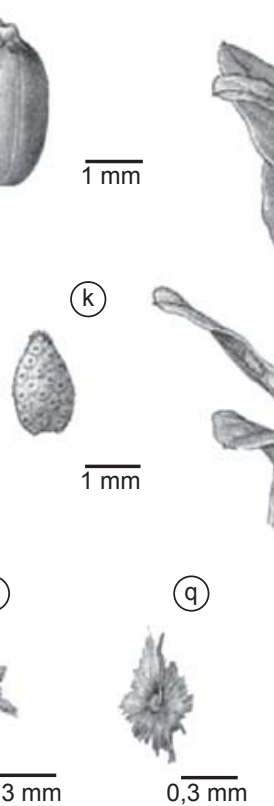

(h)

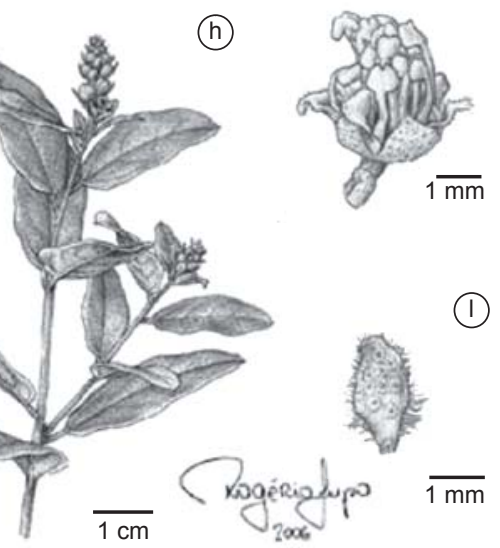

(1)

(i)
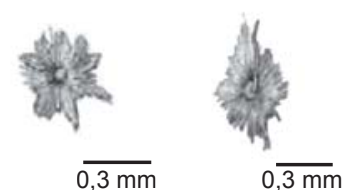

(1)

(s)

Figura 5. a-g) Croton ericoides: a) hábito; b) flor estaminada; c) flor pistilada inteira; d) flor pistilada sem três sépalas; e) sépala da flor pistilada em vista abaxial; f) sépala da flor pistilada em vista adaxial; g) semente. h-s) Croton erythroxyloides: h) hábito; i) flor estaminada inteira; j) flor estaminada sem três sépalas e duas pétalas; k) sépala da flor estaminada em vista abaxial; 1) pétala da flor estaminada em vista abaxial; $\mathrm{m}$ ) flor pistilada; $\mathrm{n}$ ) sépala maior da flor pistilada em vista adaxial; o) sépala menor da flor pistilada em vista adaxial; $p$-q) tricomas da face abaxial das sépalas das flores pistiladas em vista frontal; r) tricoma da face abaxial das sépalas das flores pistiladas em vista lateral; e s) semente. (a, c, f) Rambo s.n. PACA 61459; b) Rambo s.n. PACA 55886; g) Falkenberg 6483; e h-s) Tamashiro 857).

Figure 5. a-g) Croton ericoides: a) habit; b) staminate flower; c) entire pistillate flower; d) pistillate flower without three sepals; e) pistillate flower sepal in abaxial view; f) pistillate flower sepal in adaxial view; g) seed. h-s) Croton erythroxyloides: h) habit; i) entire staminate flower; j) staminate flower without three sepals and two petals; k)staminate flower sepal in abaxial view; 1 ) staminate flower petal in abaxial view; m)pistillate flower; $\mathrm{n}$ ) the bigger pistillate flower sepal in adaxial view; o) the smaller pistillate flower sepal in adaxial view; $\mathrm{p}$-q) trichomes of abaxial surface of pistillate flower sepals in frontal view; r) trichome of abaxial surface of pistillate flower sepals in lateral view; and s) seed. (a, c, f) Rambo s.n. PACA 61459; b) Rambo s.n. PACA 55886; g) Falkenberg 6483; and h-s) Tamashiro 857). 


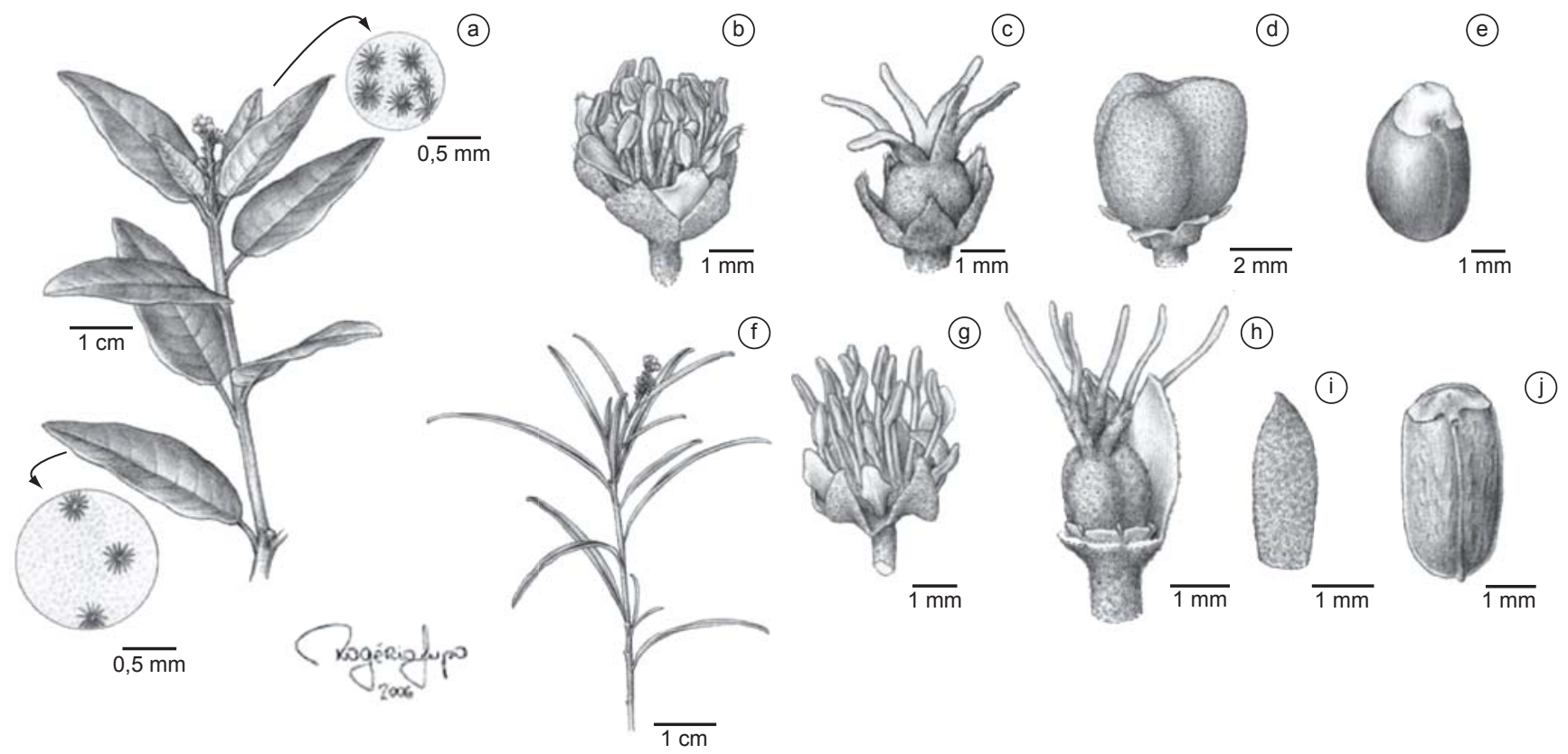

Figura 6. a-e) Croton hypoleucus: A. hábito e detalhes do indumento da face adaxial das folhas; b) flor estaminada; c) flor pistilada; d) fruto; e) semente. f-j) Croton linearifolius: f) hábito; g) flor estaminada; h) flor pistilada sem três sépalas; i) sépala da flor pistilada em vista abaxial; e j) semente. a-e) Hernandez 6282; f-g) Lima 353; h-j) Reitz 13634).

Figure 6. a-e) Croton hypoleucus: a) habit and indumentum of adaxial leaves surface in detail; b) staminate flower; c) pistillate flower; d) fruit; e) seed. f-j) Croton linearifolius: f) habit; g) staminate flower; h) pistillate flower without three sepals; i) pistillate flower sepal in abaxial view; and j) seed. a-e) Hernandez 6282; f-g) Lima 353; and h-j) Reitz 13634).

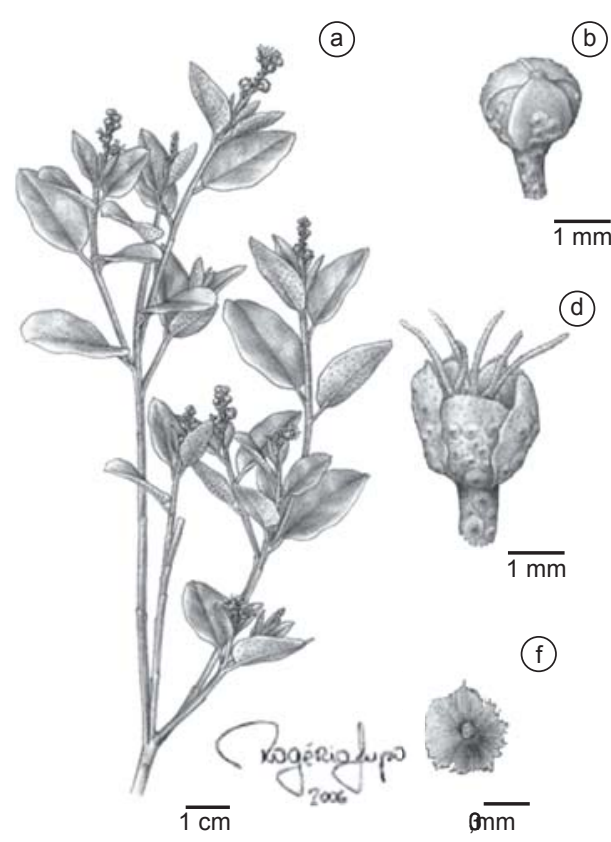

(b)

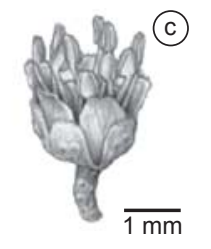

(d)
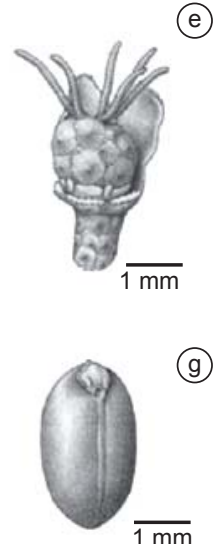

Figura 7. a-g) Croton imbricatus: a) hábito; b) botão da flor estaminada; c) flor estaminada; d) flor pistilada inteira; e) flor pistilada sem três sépalas; f) tricoma da face abaxial das sépalas das flores pistiladas; e g) semente. (a) Ganev 1423; b-c) Gonçalves 254; d-f) Pinto 415/83; e g) Carvalho 3744).

Figure 7. a-g) Croton imbricatus: a) habit; b) bud of staminate flower; c) staminate flower; d) entire pistillate flower; e) pistillate flower without three sepals; f) trichome of abaxial surface of pistillate flower sepals; and g) seed. (a) Ganev 1423; b-c) Gonçalves 254; d-f) Pinto 415/83; and g) Carvalho 3744).

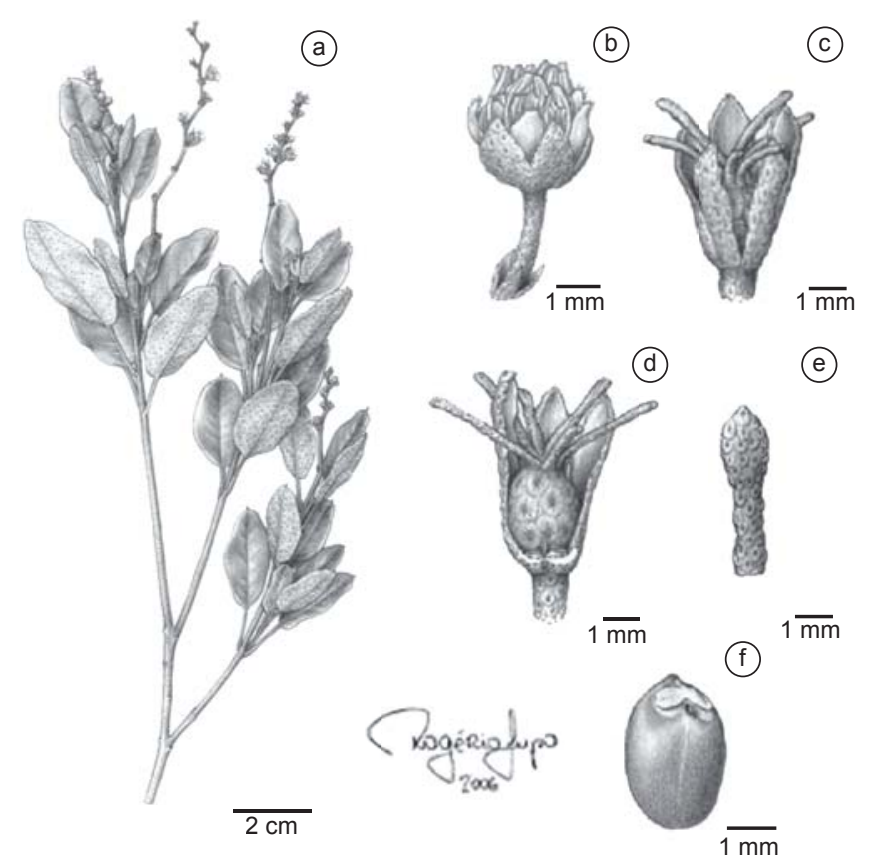

Figura 8. a-f) Croton muellerianus: a) hábito; b) flor estaminada; c) flor pistilada inteira; d) flor pistilada sem duas sépalas; e) sépala da flor pistilada em vista abaxial; e f) semente. (a, c-f) Imaguire 510; b) Ribas 943).

Figure 8. a-f) Croton muellerianus: a) habit; b) staminate flower; c) entire pistillate flower; d) pistillate flower without two sepals; e) pistillate flower sepal in abaxial view; and f) seed. (a, c-f) Imaguire 510; b) Ribas 943). 


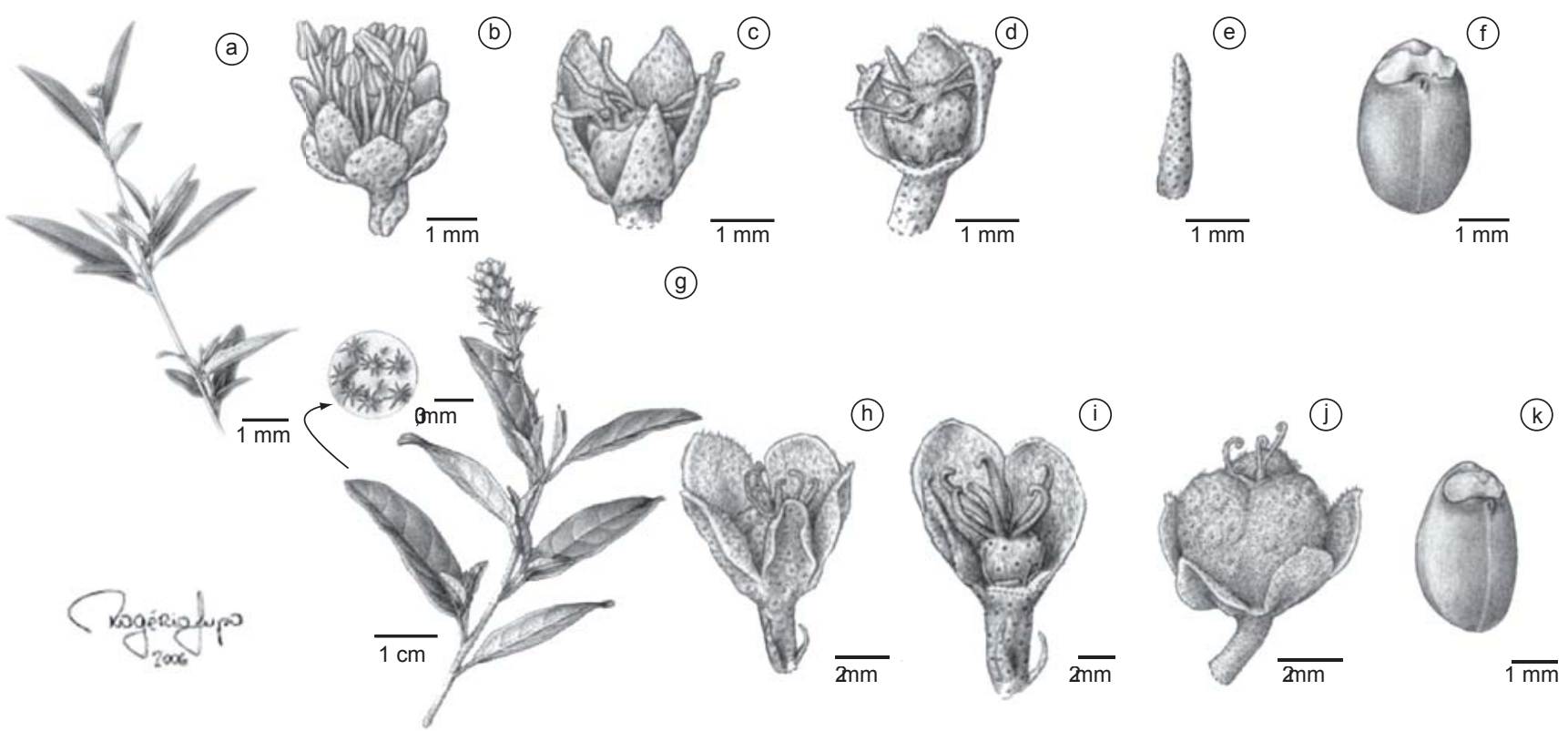

Figura 9. a-f) Croton myrianthus: a) hábito; b) flor estaminada; c) flor pistilada inteira; d) flor pistilada sem duas sépalas; e) bráctea; f) semente. g-i) Croton pallidulus var. pallidulus: g) hábito e detalhe do indumento da face abaxial das folhas; h) flor pistilada inteira; i) flor pistilada sem duas sépalas. k-1) Croton pallidulus var. glabrus: k) fruto; e 1) semente. a-e) Rambo s.n. PACA 46285; f) Rodrigues 488; g-i) Kummrow 2789; e j-k) Oliveira 128).

Figure 9. a-f) Croton myrianthus: a) habit; b) staminate flower; c) entire pistillate flower; d) pistillate flower without two sepals; e) bract; f) seed. g-i) Croton pallidulus var. pallidulus: g) habit and indumentum of abaxial leaves surface; h) entire pistillate flower; 1) pistillate flower without two sepals; i) seed. $\mathrm{k}-\mathrm{l}$ ) Croton pallidulus var. glabrus: k) fruit; and l) seed. a-e) Rambo s.n. PACA 46285; f) Rodrigues 488; g-i) Kummrow 2789; and j-k) Oliveira 128).
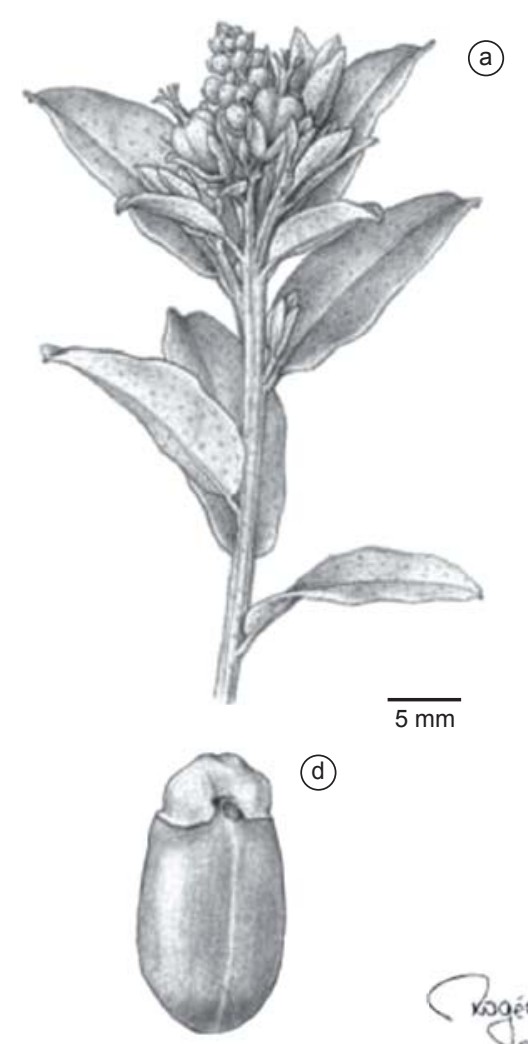

$\overline{1 \mathrm{~mm}}$

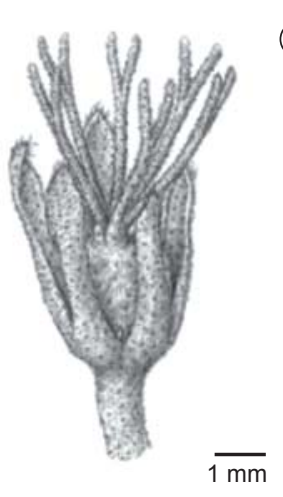

(b)

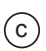

(C)
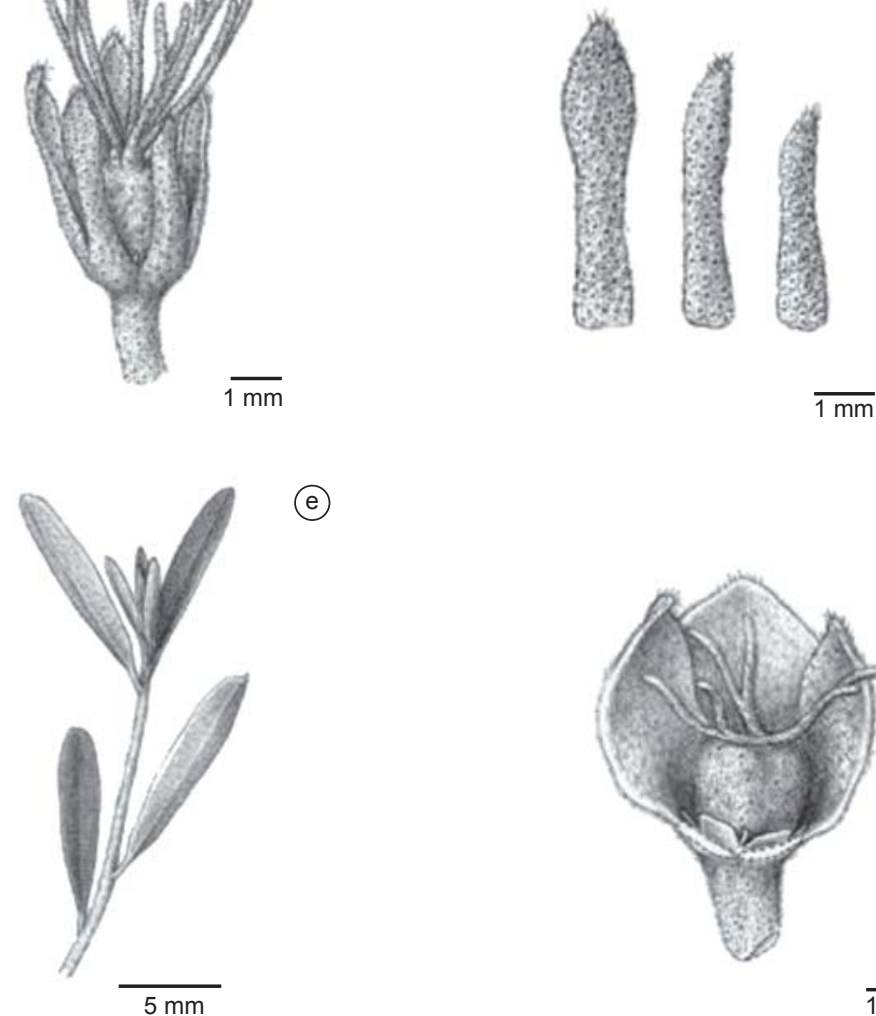

(e)

$(\uparrow$

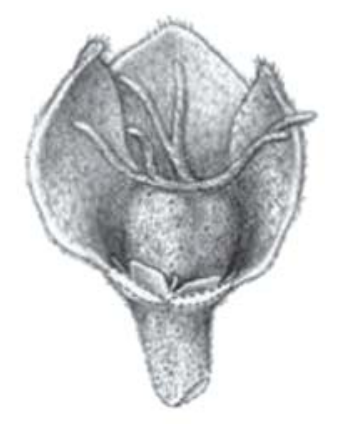

$\overline{1 \mathrm{~mm}}$

Figura 10. a-d) Croton paraguayensis: a) hábito; b) flor pistilada; c) sépalas desiguais das flores pistiladas em vista adaxial; d) semente. e-f) Croton perintrincatus: e) hábito; e f) flor pistilada sem duas sépalas. (a-d) Schinini 4426; e e-f) Fiebrig 2510).

Figure 10. a-d) Croton paraguayensis: a) habit; b) pistillate flower; c) unequals pistillate flower sepals in adaxial view; d) seed. e-f) Croton perintrincatus: e) habit; e f) pistillate flower without two sepals. (a-d) Schinini 4426; and e-f) Fiebrig 2510). 



(b)
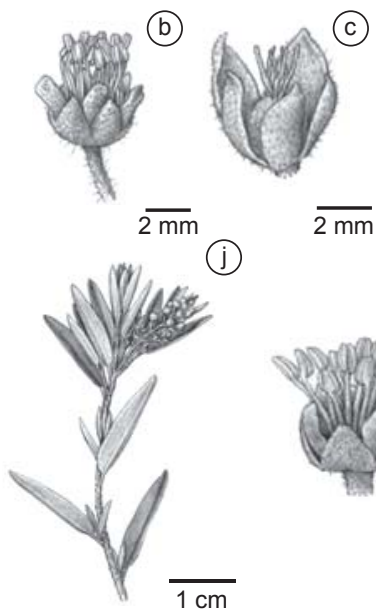

(d)

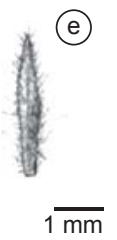

(1)
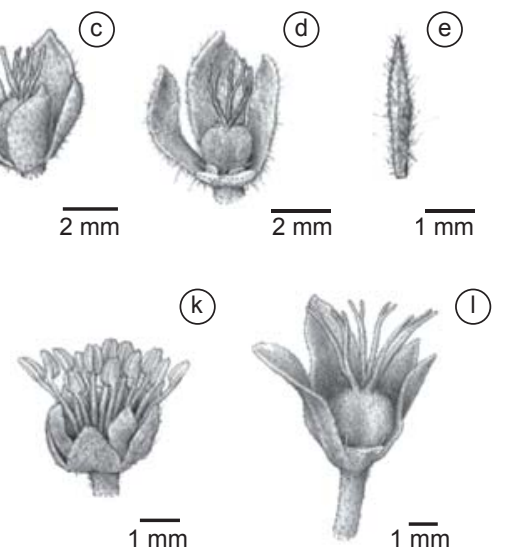

(
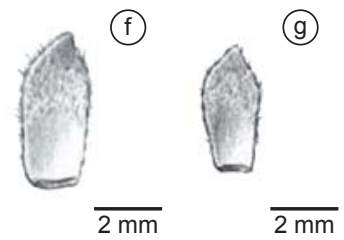

(m)

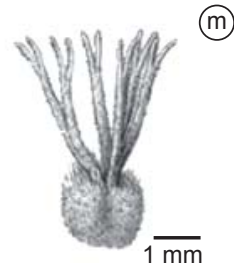

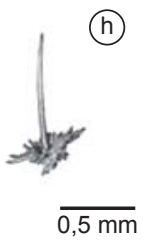

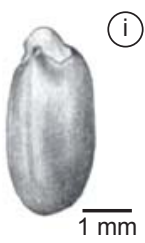

(n)

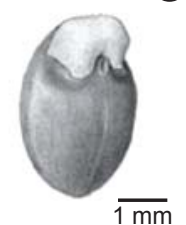

Figura 11. a-i) Croton pseudoadipatus: a) hábito; b) flor estaminada; c) flor pistilada inteira; d) flor pistilada sem duas sépalas; e) bráctea; f) sépala anterior da flor pistilada em vista adaxial; g) sépala média da flor pistilada em vista adaxial; h) tricoma da face adaxial das sépalas das flores pistiladas; i) semente. j-n) Croton serpyllifolius: j) hábito; k) flor estaminada; 1) flor pistilada sem uma sépala; m) gineceu; e n) semente. a-h) Costa 182; i) Arbo 4960; e j-n) Souza 7030).

Figure 11. a-i) Croton pseudoadipatus: a) habit; b) staminate flower; c) entire pistillate flower; d) pistillate flower without two sepals; e) bract; f) previous pistillate flower sepal in adaxialview; g) middle pistillate flower sepal in adaxial view; h) trichome of adaxial surface of pistillate flower sepals; i) seed. $\mathrm{j}$-n) Croton serpyllifolius: j) habit; k) staminate flower; 1) pistillate flower without one sepal; m) gynoecium; and n) seed. a-h) Costa 182; i) Arbo 4960; and j-n) Souza 7030).
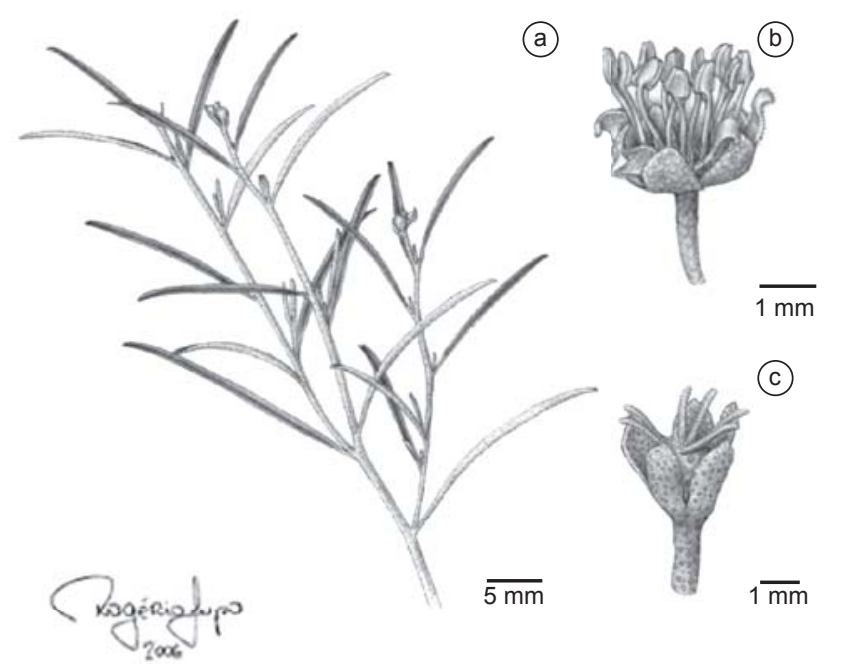

(d)
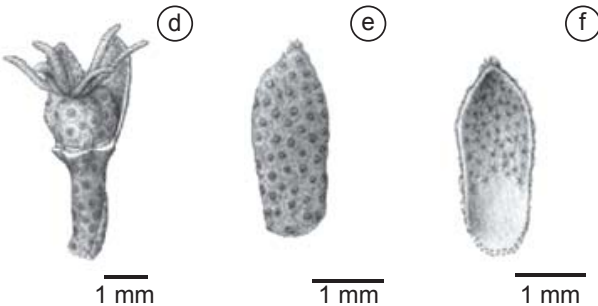

(f)

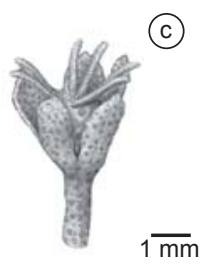

$\overline{1 \mathrm{~mm}}$

Figura 12. Croton pygmaeus: a) hábito; b) flor estaminada; c) flor pistilada inteira; d) flor pistilada sem três sépalas; e) sépala da flor pistilada em vista abaxial; f) sépala da flor pistilada em vista adaxial; e g) semente. a) Falkenberg 6483; b) Rossoni 96; c-e) Rossoni 225; e g) Sobral 5115).

Figure 12. Croton pygmaeus: a) habit; b) staminate flower; c) entire pistillate flower; d) pistillate flower without three sepals; e) pistillate flower sepal in abaxial view; f) pistillate flower sepal in adaxial view; and g) seed. a) Falkenberg 6483; b) Rossoni 96; c-e) Rossoni 225; and g) Sobral 5115).
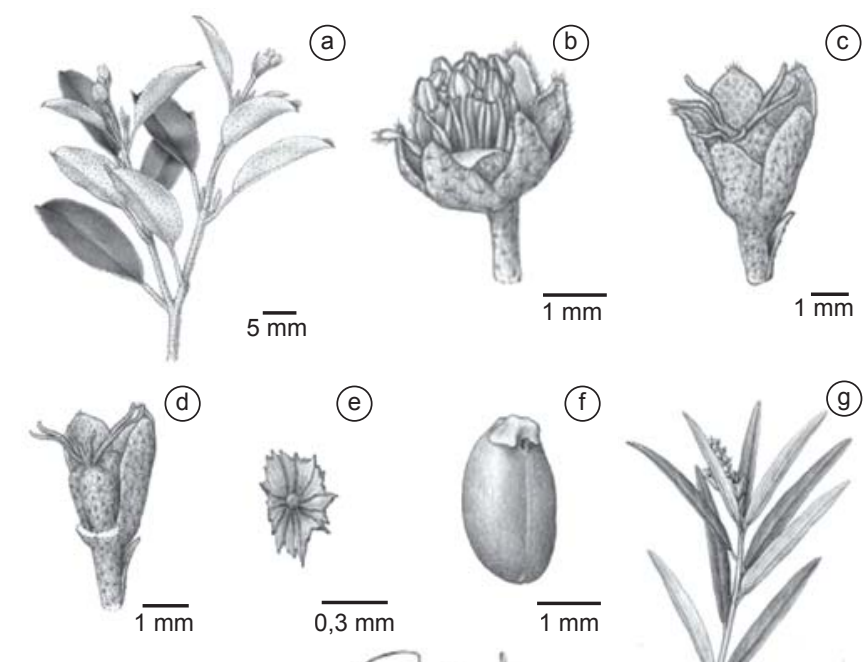

(e)
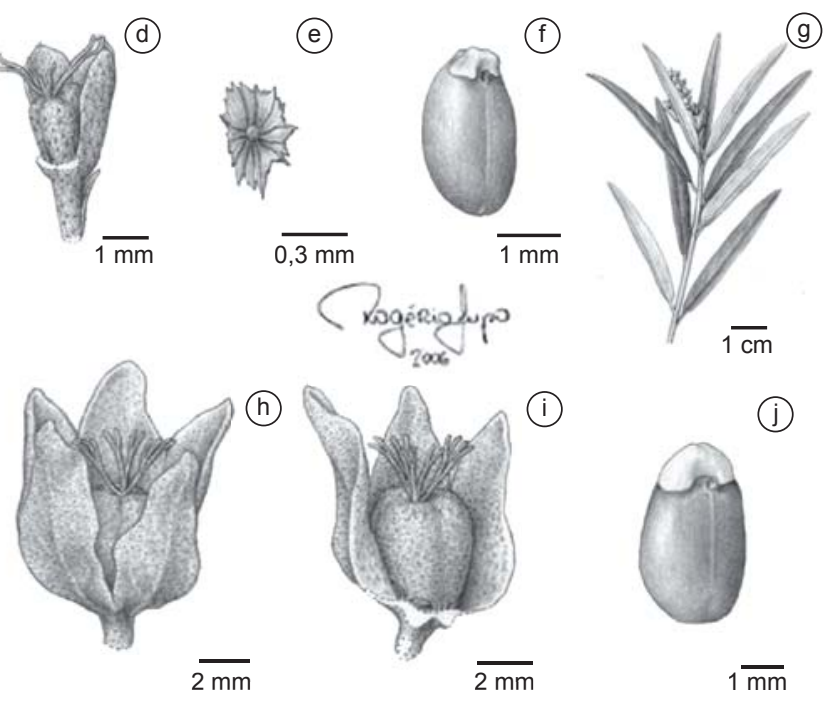

(i)

(i)

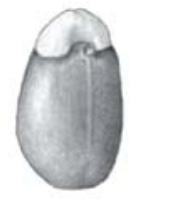

$1 \overline{\mathrm{mm}}$

Figura 13. a-f) Croton splendidus: a) hábito; b) flor estaminada; c) flor pistilada inteira; d) flor pistilada sem duas sépalas; e) tricoma da face abaxial das sépalas das flores pistiladas; f) semente. g-j) Croton subcinerellus: g) hábito; h) flor pistilada inteira; i) flor pistilada sem duas sépalas; e g) semente. a-e) Pirani 367; f) Shepherd 5776; e g-j) Hassler 5126).

Figure 13. a-f) Croton splendidus: a) habit; b) staminate flower; c) entire pistillate flower; d) pistillate flower without two sepals; e) trichome of abaxial surface of pistillate flower sepals; f) seed. g-j) Croton subcinerellus: g) habit; $\mathrm{H}$. entire pistillate flower; i) pistillate flower without two sepals; and g) seed. a-e) Pirani 367; f) Shepherd 5776; and g-j) Hassler 5126). 


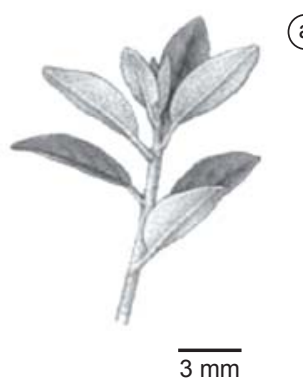

(e)

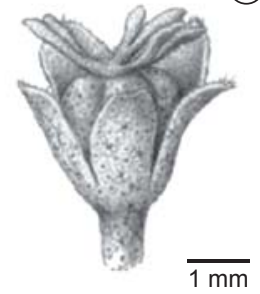

(b)

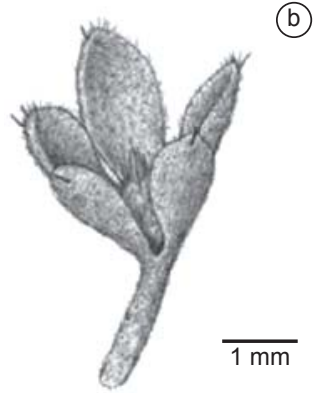

$(\uparrow)$

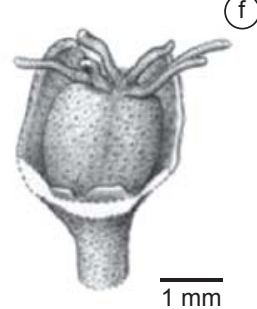

(c)

(d)
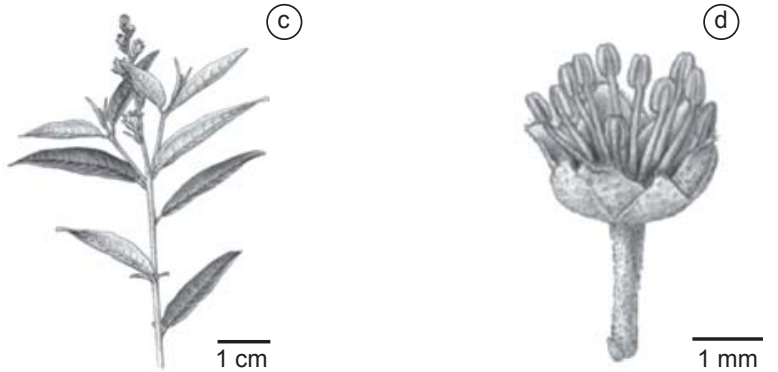

(9)

(b)

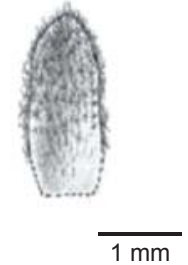

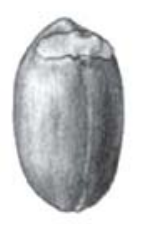

$\overline{1 \mathrm{~mm}}$

Figura 14. a-b) Croton tenellus: a) hábito; b) cálice da flor pistilada. c-h) Croton uruguayensis: c) hábito; d) flor estaminada; e) flor pistilada inteira; f) flor pistilada sem três sépalas; g) sépala da flor pistilada em vista adaxial; e h) semente. a-b) Martius s.n. M 0089121; c, e-g) Schinini 5846; d) Schinini 23497; e h) Schinini 5410).

Figure 14. a-b) Croton tenellus. a) habit; b) pistillate flower sepals. c-h) Croton uruguayensis. c) habit; d) staminate flower; e) entire pistillate flower; f) pistillate flower without three sepals; g) pistillate flower sepal in adaxial view; and h) seed. a-b) Martius s.n. M 0089121; c, e-g) Schinini 5846; d) Schinini 23497; and h) Schinini 5410).
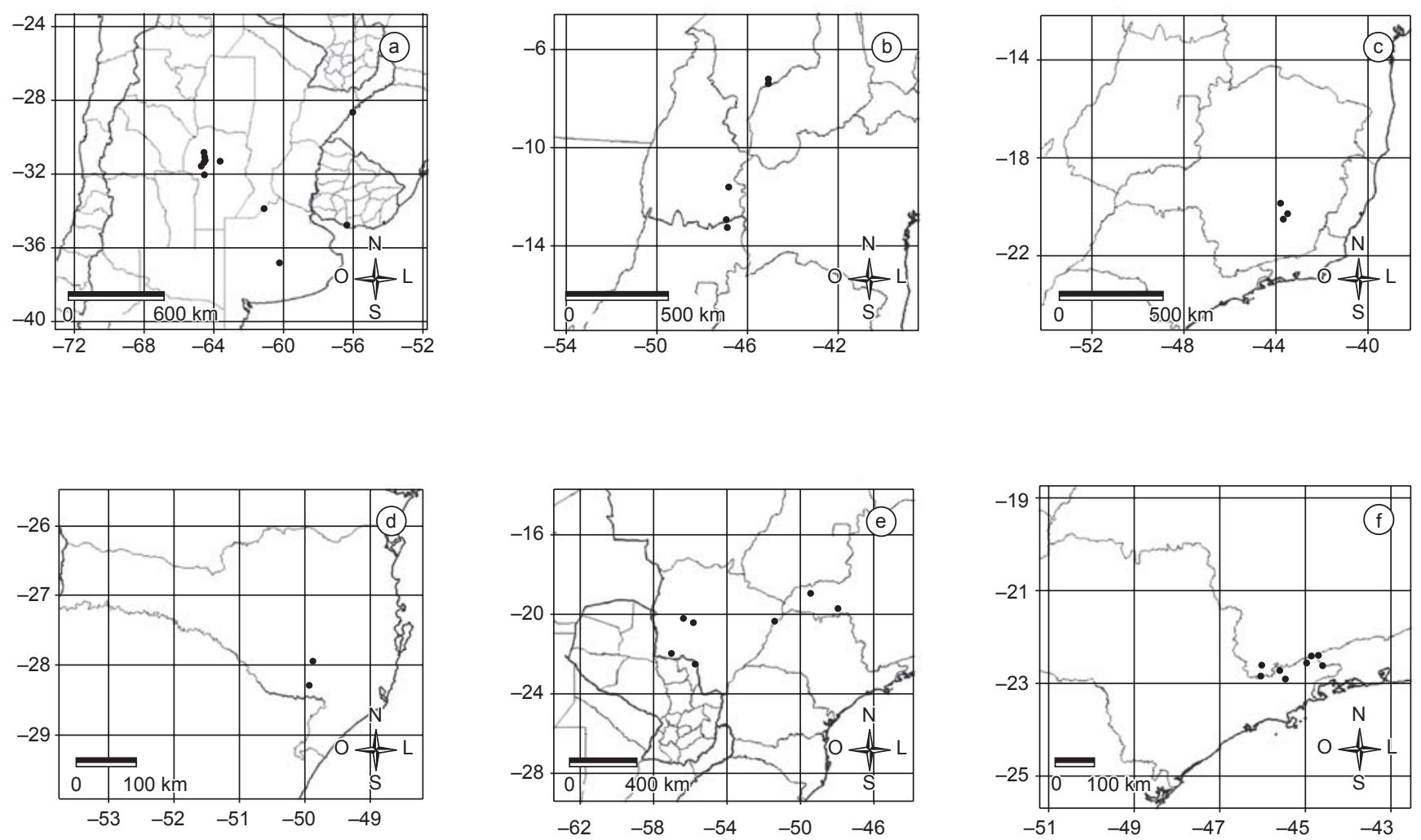

Figura 15. Mapas de distribuição geográfica das espécies de Croton sect. Lamprocroton: a) C. argentinus; b) C. burchellii; c) C. ceanothifolius; d) C. chloroleucus; e) C. cinerellus; e f) C. dichrous.

Figure 15. Geographic distribution maps of Croton sect. Lamprocroton species: a) C. argentinus; b) C. burchellii; c) C. ceanothifolius; d) C. chloroleucus; e) C. cinerellus; and f) C. dichrous. 

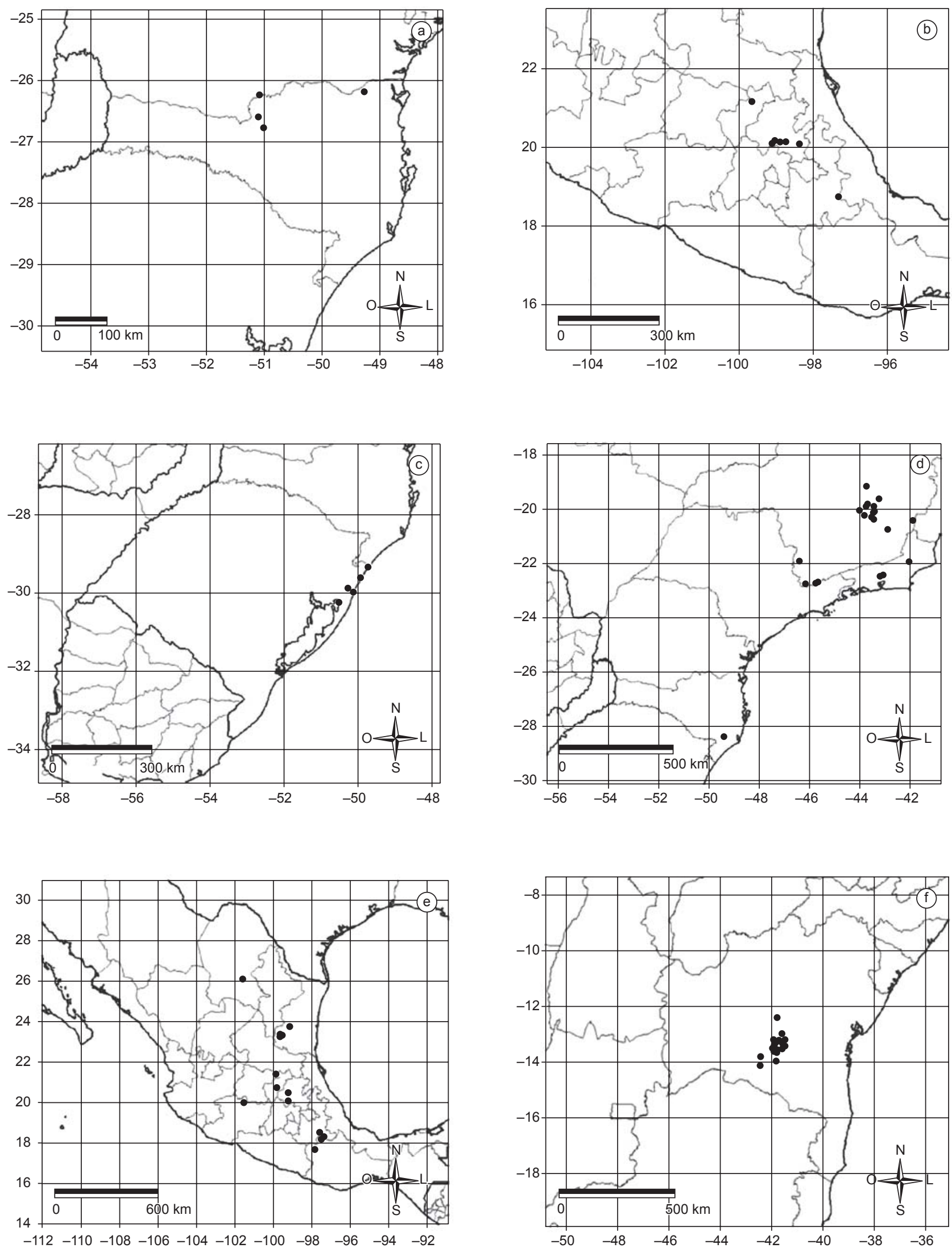

Figura 16. Mapas de distribuição geográfica das espécies de Croton sect. Lamprocroton: a) C. dusenii; b) C. ehrenbergii; c) C. ericoides; d) C. erythroxyloides; e) C. hypoleucus; e f) C. imbricatus.

Figure 16. Geographic distribution maps of Croton sect. Lamprocroton species: a) C. dusenii; b) C. ehrenbergii; c) C.ericoides; d) C. erythroxyloides; e) C. hypoleucus; and f) C. imbricatus. 

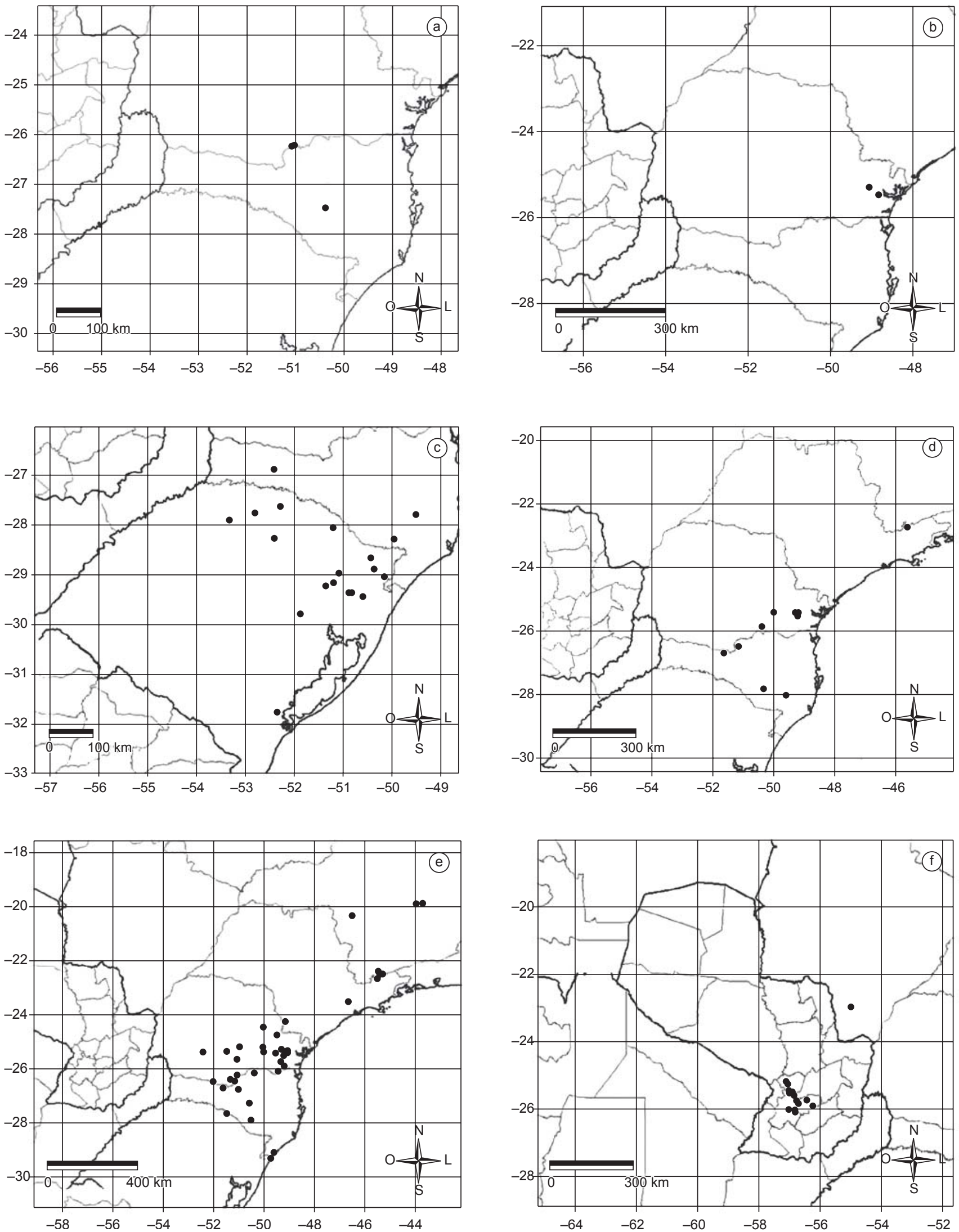

Figura 17. Mapas de distribuição geográfica das espécies de Croton sect. Lamprocroton: a) C. linearifolius; b) C. muellerianus; c) C. myrianthus; d) C. pallidulus var. glabrus; e) C. pallidulus var. pallidulus; e f) C. paraguayensis.

Figure 17. Geographic distribution maps of Croton sect. Lamprocroton species: a) C. linearifolius; b) C. muellerianus; c) C. myrianthus; d) C. pallidulus var. glabrus; e) C. pallidulus var. pallidulus; and f) C. paraguayensis. 

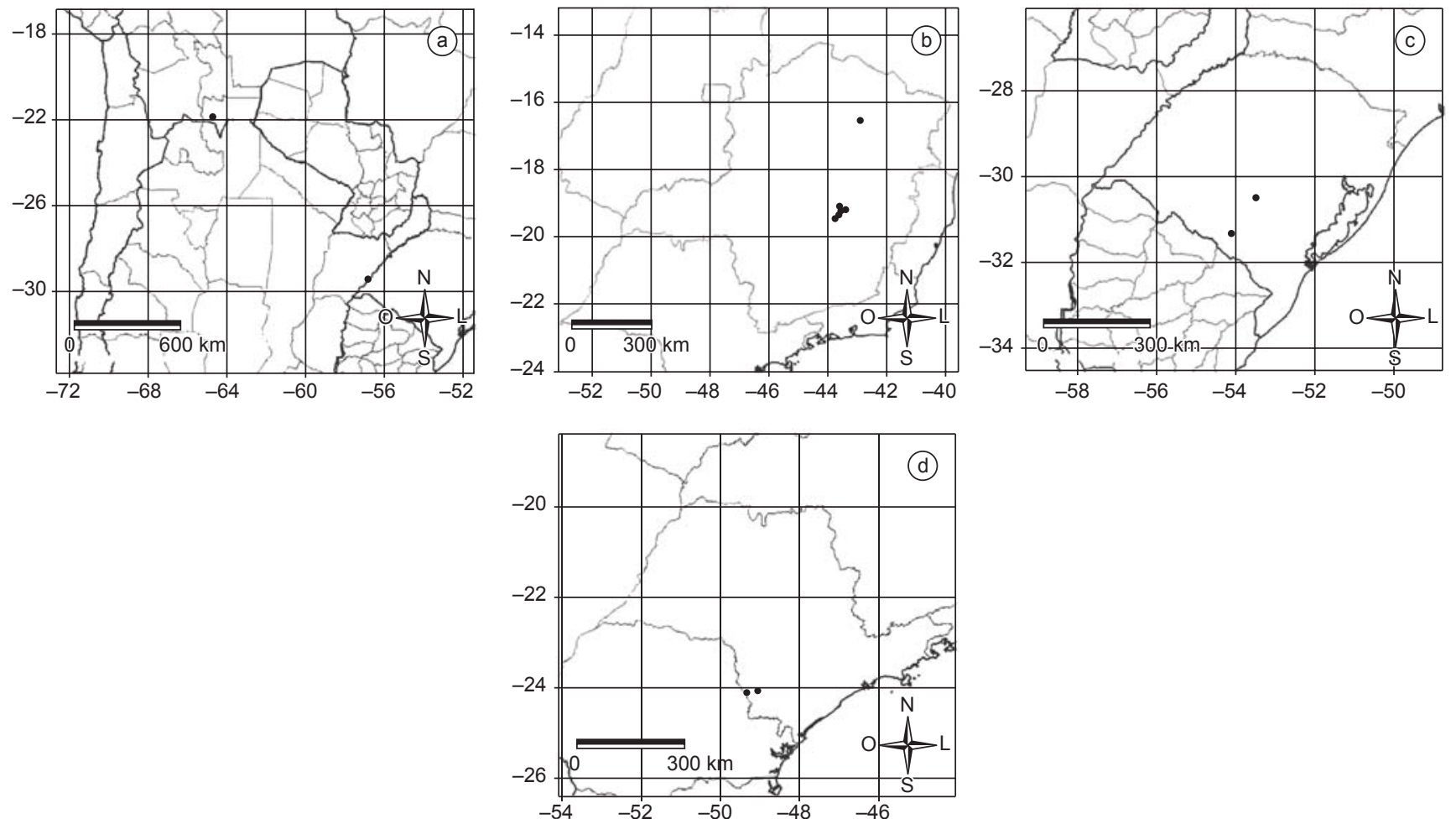

Figura 18. Mapas de distribuição geográfica das espécies de Croton sect. Lamprocroton: a) C. perintrincatus; b) C. pseudoadipatus; c) C. pygmaeus; e d) C. serpyllifolius.

Figure 18. Geographic distribution maps of Croton sect. Lamprocroton species: a) C. perintrincatus; b) C. pseudoadipatus; c) C. pygmaeus; and d) C. serpyllifolius.
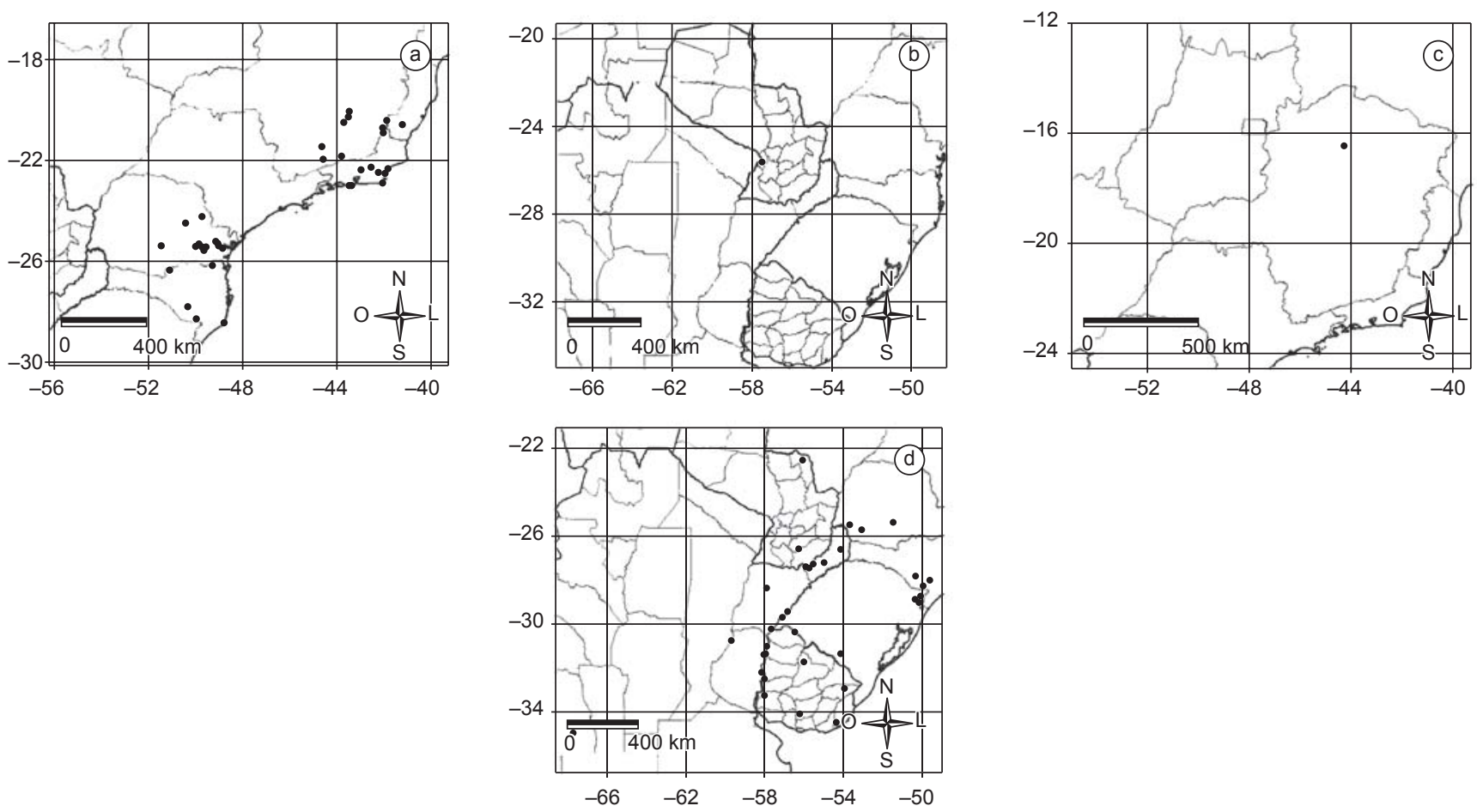

Figura 19. Mapas de distribuição geográfica das espécies de Croton sect. Lamprocroton: a) C. splendidus; b) C. subcinerellus; c) C. tenellus; e d) C. uruguayensis.

Figure 19. Geographic distribution maps of Croton sect. Lamprocroton species: a) C. splendidus; b) C. subcinerellus; c) C. tenellus; and d) C. uruguayensis. 

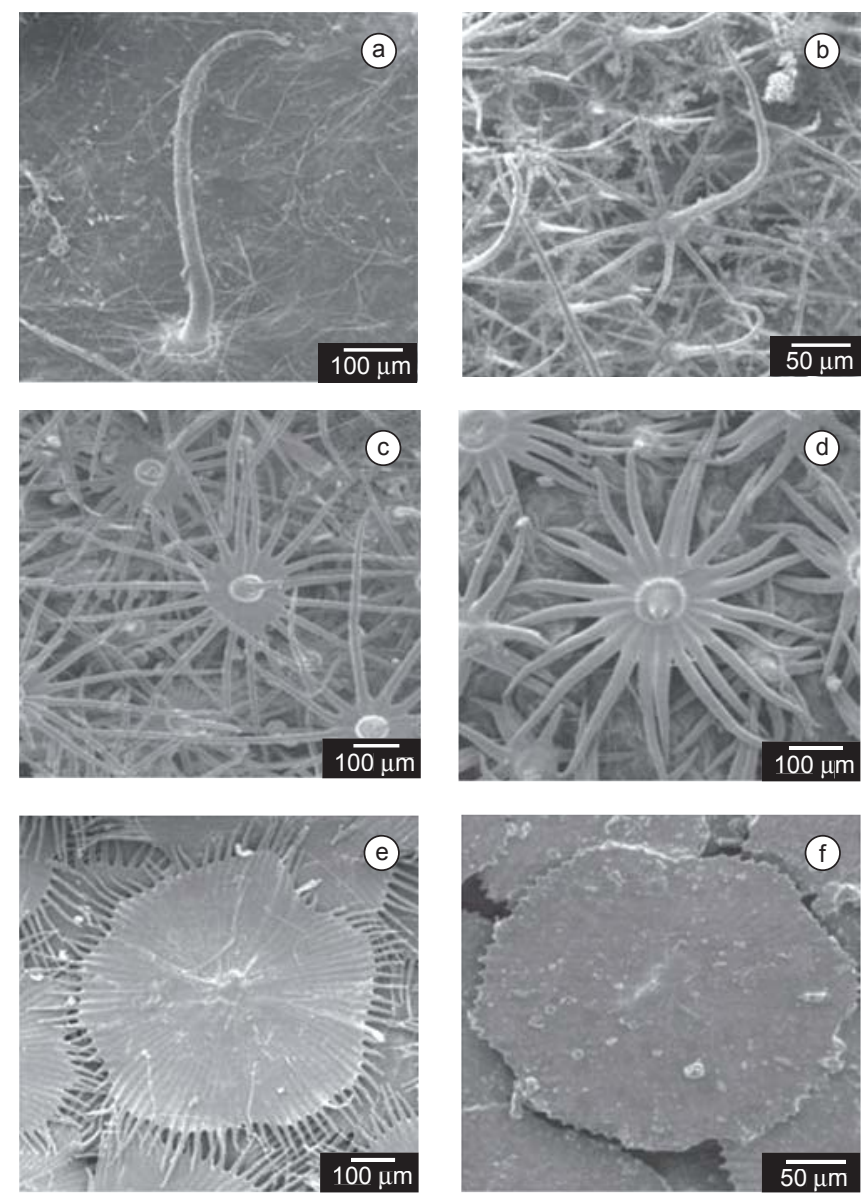

Figura 20. a-f) Tricomas da lâmina foliar das espécies de Croton sect. Lamprocroton obtidas por meio de microscopia eletrônia de varredura: a) C. ceanothifolius, tricoma simples na face adaxial; b) C. dusenii, tricoma estrelado na face adaxial; c) $C$. pallidulus, tricoma pseudo-lepidoto na face abaxial; d) C. ehrenbergii, tricoma estrelado-lepidoto na face adaxial; e) C. muellerianus, tricoma lepidoto-típico na face abaxial; e f) C. imbricatus, tricoma lepidoto-típico na face abaxial.

Figure 20. a-f) Trichomes of the leaves surface of Croton sect. Lamprocroton made using scanning eletronic microscope: a) C. ceanothifolius, simple trichome in adaxial surface; b) C. dusenii, stellate trichome in adaxial surface; c) C. pallidulus, pseudo-lepidote trichome in abaxial surface; d) C. ehrenbergii, stellate-lepidote trichome in adaxial surface; e) C. muellerianus, typicallepidote trichome in abaxial surface; and f) C. imbricatus, typical-lepidote trichome in abaxial surface.

\section{Lista dos coletores de Croton sect. Lamprocroton (Müll. Arg.) Pax}

Os números entre parênteses correspondem ao número de cada espécie no corpo do texto. As coleções-tipo não estão aqui listadas.

1. Croton argentinus

2. C. burchellii

3. C. ceanothifolius

4. C. chloroleucus

5. C. cinerellus

6. C. dichrous

7. C. dusenii

8. C. ehrenbergii

9. C. ericoides

10. C. erythroxyloides

11. C. eskuchei

\section{C. hypoleucus}

13. C. imbricatus

14. C. linearifolius

15. C. muellerianus

16. C. myrianthus

17.1. C. pallidulus var. glabrus

17.2. C. pallidulus var. pallidulus

18. C. paraguayensis

19. C. perintrincatus

20. C. pseudoadipatus

21. C. pygmaeus

22. C. serpyllifolius

23. C. splendidus

24. C. subcinerellus

25. C. tenellus

26. C. uruguayensis

Abreu, A.T.: s.n. OUPR 4216 (3). Ahumada, O.: 2871 (26). Allem, A. s.n.: ICN 25278 (9); ICN 26918 (16); ICN 29447 (17.2). Alvarez, A.: s.n. ICN 30505 (16). Alves, M.: 1200 (13); 1232 (13).

Amaral Jr., A.: 5-28583 (17.2). Anderson, W.R.: 6827 (2). Andrade, I.R.: 291 (23). Arbo, M.M.: 1722 (18); 2854 (26); 4023 (10); 4050 (23); 4101 (10); 4816 (20); 4960 (20). Arbocz, G.F.: 1225 (10); 1598 (17.2); 1616 (17.2). Arenas, P.: 295 (18). Arzivenco, L.: 167 (16). Arzivenco, L.: s.n. ICN 42104 (16). Attala, N.C.: 62 (23); 74 (23).

Bacon, J.: 1730 (12). Badini, J.: s.n. OUPR 5549 (23); OUPR 6104 (23); OUPR 6105 (23). Baeta, A.: s.n. OUPR 6099 (23). Balansa, B.: 1649 (18); 1650 (26); 4670 (18). Baptista, L.R.M.: s.n. ICN 24311 (16); ICN 62675 (16); ICN 69904 (21); K s.n. (16). Barb., A.: 117 (10). Barbosa, E.R.: s.n. SP 338838 (23). Barreto, K.D.: 1069 (6); 1274 (17.2). Barreto, M.: 1195 (20); 2699 (23); 2701 (10); 8119 (10); 9114 (3); 9115 (23). Barros, F.: 2760 (20). Basualdo, I.: 251 (18). Bautista, H.P.: 292 (6). Bernardi: 18044 (18); 18718 (18). Bertoni: 819 (26); 2156 (26); 2218 (26); 4783 (26). Bordas, E.: 4371 (18). Borhidi, J.A.: s.n. OUPR 6148 (20). Bornmüller, A.: 729 (16). Bottino, O.: 52 (26). Bovini, M.G.: 2057 (23). Braga, M.M.N.: 155 (10). Braga, M.M.N.: s.n. BHCB 13771 (10); BHCB 13374 (23); BHCB 13375 (10); SP 238035 (23); SPF 238035 (23). Braga, P.I.S.: 2040 (10). Brade, A.C.: 16978 (10); 20681 (6). Brandão, F.L.S.: s.n. OUPR 3693 (3). Brina, A.E.: s.n. BHCB 60048 (10); BHCB 60074 (10). Britez, R.M.: 826 (17.1). Bruxel, A.: s.n. PACA 6806 (26); PACA 6821 (17.1). Buck, P.: s.n. PACA 11549 (16); PACA 11636 (16). Burchell: 5645 (5). Burkart, A.: 7295 (1); 24840 (26). Butzke, A.: s.n. HUCS 11671 (16).

Caballero, L.C.R.: 44 (18). Cabrera, A.L.: 3254 (26). Camargo, O.R.: 84 (16); 2200 (16); 2578 (16); 3365 (16). Camargo, R.F.N.: 23 (23). Cameril, A.M.: 26 (6); 242 (10). Campos, A.C.: 986 (3). Campos, A.C.: s.n. OUPR 2483 (3). Campos, M.T.V.A.: CFSC 13323 (20); CFSC 13483 (20). Carauta, P.: 1742 (17.2). Carmo, M.: s.n. BHCB 36017 (10); BHCB 36018 (10); BHCB 63264 (10); MBM 258702 (10). Carnevali, R.: 3561 (26). Carranza, E.: 2973 (8). Caruzo, M.B.R.: 30 (17.2); 31 (17.2); 59 (6); 60 (6); 61 (6); 62 (6); 68 (17.2); 69 (6); 70 (17.2); 74 (10). Carvalho, A.M.: 3744 (13). Casari, M.B.: 273 (23). Casas, J.F.: 3554 (18). Castellanos: s.n. CTES 31/1117 (26). Cervi, A.C.: 2230 (17.2); 2896 (17.1); 4086 (23); 6226 (23); 6420 (23). Charpin, A.: 21286 (18). Chodat: 401 (18). Claussen, M.: 6 (23); 60 (23); 398 (10). Claussen, P.: 6 (23); 184 (10); 210 (3); 451 (23). Claussen, P.: s.n. GDC s.n. (23); K s.n. (10); K s.n. (23); P. s.n. (10); P s.n. (23); W 134035 (3). Coelho, L.E.: s.n. OUPR 3723 (3). Conceição, A.A.: CFSC 13930 (20). Cordeiro, I.: 2771 (6); 2772 (17.2); 2773 (17.2); CFSC 10476 (10); CFSC 10499 (10); CFSC 10500 (10). Cordeiro, J.: $167(17.1) ; 312$ (23); 1355 (23). Costa, C.B.: 176 (10). Costa, F.N.: 128 (20); 130 (20); 182 (20). Crovetto, R.M.: 
4176 (26); 4685 (26); 8716 (26). Cruz, N.D.: 6320 (23); 6389 (23). Cuislobro, M.L.: 87 (1). Curial, O.: 542 (15). Custódio: 61 (23).

Damazio, L.: 107 (3); 1006 (3). Damazio, L.: s.n. OUPR 6101 (23); OUPR 6114 (10); RB 82951 (6); RB 82952 (10); RB 82964 (20); RB 82984 (16); RB 82998 (16). Davis, P.H.: 2963 (6); 3088 (17.2); 61016 (17.2). Degen, R.: 292 (18); 418 (18); 482 (18). Diesel, S.: 1252 (16); 1559 (16); 2424 (16). Diggs, G.: 2357 (12). Dombrowski, L.T.: 102 (23); 868 (17.1); 891 (17.2); 1014 (23); 1936 (17.2); 2963 (23); 4306 (17.2); 4532 (23); 10399 (17.2); 10639 (23); 11416 (17.2); 11440 (17.2); 11836 (17.2); 12228 (23); 13546 (17.2); 13894 (23). Duarte, A.P.: 7691 (6); 1187 (23); 13968 (23). Duré, R.: 238 (18). Dusén, P.: 102 (6); 9372 (17.2); 9401 (17.2); 17188 (17.1). Dziewa, A.: 38 (17.2).

Ehrendorfer, F.: 73906-26 (6). Eiten, G.: 4268-B (2); 4562 (2); 6558 (6); 6676 (6); 7145 (10); 10609 (2); 10791-A (2). Ekman, E.L.: 457 (26); 458 (26). Elcione, M.N.: 1742 (10). Emrich, K.: s.n. PACA 28750 (16). Emygdio, L.: 3249 (10); 3341 (10).

Falcão, C.L.: 1 (23). Falkenberg, D.B.: 3483 (17.2); 3485 (17.2); 6280 (16); 6294 (16). Farney, C.: 50 (23); 105 (23); 808 (10); 1198 (10). Favalli, J.: s.n. ICN 7060 (17.2). Fbarrola, C.: 2020 (26). Fernández, I.: 724 (21). Ferreira, L.F.: 40 (17.2); 194 (17.1). Ferreira, W.M.: 196 (23). Fiaschi, P.: 495 (17.2); 760 (10). Fiebrig, K.: 690 (18); 4560 (24); 5385 (26). Flaster, B.: 97 (23). Fleig, M.: 411 (16). Fontella, J.P.: 221 (23). Forero, E.: 3753 (17.2). Forster, W.: 61 (23). Forzza, R.C.: 964 (10); 1116 (13). França, F.: 2522 (23). Frediani, P.: s.n. PACA 57365 (16). Freitas, L.: 15 (6); 16 (6); 17 (6); 619 (6). Fruchard, M.: 767 (1); 11262 (26). Furlan, A.: 130 (6); CFCR 1685 (13); CFCR 1979 (13); CFSC 5994 (20).

Gallinal, R.: 5721 (26); PE-5214 (26). Gandover, M.: s.n. MO 1905224 (23). Ganev, W.: 1423 (13); 2054 (13); 2431 (13). Gardner: 2953 (2); 5173 (10); 5773 (10); 5833 (10). Gaudichaud, C.: 176 (23). Gibbs, P.E.: 5428 (5). Ginzbarg, S.: 118 (12); 432 (18); 433 (18). Ginzberger, A.: s.n. W 9388 (6). Girardi-Deiro, A.M.: 599 (26); 984 (21). Giulietti, A.M.: 1632 (13); CFSC 5628 (20); CFSC 6407 (20). Glaziou, M.A.: 728 (23); 3743 (10); 6128 (23); 6681 (6); 7821 (23); 11550 (6); 13174 (23); 13175 (23); 15401 (10); 16334 (10); 17216 (23). Glaziou, M.A.: s.n. G s.n. (23); P s.n. (23). Godenberg, R.: 26418 (6). Gomes, C.G.: 152 (10). Gonçalves, L.M.C.: 254 (13). Gonçalves, P.: 3192 (10). González, L.: 3379 (12). González-Medrano, F.: 9984 (12). Grandi, T.S.M.: 143 (23). Grisebach: s.n. K s.n. (1). Grondona, E.: 1275 (26). Gubert, M.E.: 262 (26). Guedes, M.L.: s.n. ALCB 27921 (23); SPF 118154 (23). Gutiérrez, J.: 97 (1).

Hahn, W.: 2666 (18). Handro, O.: 781 (6). Harley, R.M.: 20080 (13); 24341 (13). Hashimoto, G.: 39 (6). Hassler, D.E.: 126 (24); 4038 (18); 9366 (24); 11279 (18). Hatschbach, G.: 542 (15); 623 (17.2); 1746 (15); 2810 (17.2); 3963 (17.2); 4566 (23); 5571 (23); 6027 (23); 7400 (17.2); 8184 (23); 9223 (23); 10090 (17.2); 13717 (17.2); 14585 (17.2); 14989 (17.2); 14989-A (17.2); 14989-B (17.2); 16461 (23); 17638 (17.1); 18298 (17.2); 20578 (26); 21646 (23); 23919 (17.2); 25385 (15); 26228 (17.2); 26815 (17.2); 28843 (20); 29184 (17.2); 29910 (20); 30385 (17.2); 30678 (14); 38846 (17.2); 40001 (17.2); 40224 (23); 44586 (15); 53442 (13); 56674 (13); 58852 (5); 59670 (23); 60420 (2); 60597 (17.2); 61342 (16); 64536 (17.2); 72370 (17.2). Hatschbach, G.: s.n. MBM 39978 (23); PACA 33645 (23). Hauman: s.n. CTES 38073 (26). Hensold, N.: CFCR 2777 (23). Henz, E.: s.n. PACA 35760 (16). Hernández, M.R.: 3308 (8); 3701 (12); 6215 (12); 6282 (12). Hieronymus, G.: s.n. G s.n. (1); K s.n. (1). Hieronymus, G.: 204 (1); 205 (1). Hinton, G.B.: 24463 (12). Hoehne, F.C.: 2837 (10); 4947 (10). Hoehne, F.C.: s.n. SPF 13289 (17.2). Hoehne, W. 5580 (23); 5626 (23). Hoehne, W.: s.n. SP 48514 (17.2). Homrich, M.H.: s.n. ICN 20786 (17.2). Horta, M.B.: 25 (23); 213 (23); 266 (23). Horta, M.B.: s.n. BHCB 12333 (23). Hunt, D.R.: 5408 (23). Hunziker, A.T.: 6953 (1); 6959 (1); 8532 (1); 9090 (1); 17467 (1).
Ibarrola, C.: 1732 (26). Imaguire, N.: 179 (17.2); 291 (23); 510 (15); 5020 (17.1); 5618 (23); 8536 (17.2). Insaurralde, T.: 1112 (26). Irgang, B.: s.n. ICN 26922 (26); ICN 29761 (9); ICN 50462 (16); ICN 50463 (16); ICN 81157 (3); ICN 81213 (16). Irwin, H.S.: 2769 (23); 19822 (10); 20342 (20); 28851 (23); 29495 (3); 30234 (10); 30646 (10)

J.C.L.: s.n. ICN 9267 (9). Jesus, J.A.: 1302 (23); 1627 (23). Johnston, M.C.: 11144 (12); 11159 (12); 11710 (12). Joly, A.B.: 1326 (20). Joly, A.B.: s.n. SPF 19660 (23). Jorgensen, P.: 1328 (26); 3519 (18).

Kegler, A.: 38 (16); 647 (16); 669 (16). Kiesling, R.: 9838 (18). Kinoshita, L.S.: 98-241 (23); 16484 (17.2). Kirizawa, M.: 1499 (6), 3518 (6). Klein, R.: 3018 (17.2); 3052 (17.2); 3092 (17.2); 3094 (17.2). Koch, I.: 26346 (17.2). Koczicki, C.: 294 (10). Körner, L.: s.n. ICN 5727 (16). Krapovickas, A.: 15431 (26); 21681 (26); 28994 (26); 29129 (26); 33543 (23); 33660 (17.2); 34243 (26); 35484 (10); 37786 (10); 38371 (4); 38470 (17.2); 42046 (23); 45698 (18). Krieger, L.: 537 (23); 1014 (17.2); 11245 (17.2); 9733 (10); 14167 (23); 22299 (23). Kuhlmann, E.: s.n. SP 75857 (6). Kuhlmann, M.: 2442 (17.2); 2591 (10); 2592 (10). Kuhlmann, M.: s.n. RB 80706 (17.2); SP 40236 (17.2). Kuhn, E.: 2058 (6). Kummrow, R.: 591 (15); 1140 (17.2); 1525 (23); 1570 (17.2); 1894 (17.2); 2785 (17.2); 2788 (17.2); 2789 (17.2); 3055 (17.2). Kuniyoshi, Y.S.: 5513 (23). Kuntze, O.: s.n. NY s.n. (26).

Labiak, P.H.: 2067 (23). Laessoe, T.: H 52513 (13). Landrum, L.R.: 2109 (6); 2125 (6); 2511 (17.2); 2546 (23); 4259 (10). Langsdorff: s.n. K s.n. (23). Lanje, R.: s.n. MBM 195573 (17.1); RB 125793 (17.1). Laustyac, L.: s.n. RB 93546 (6). Legrand, C.D.: 554 (26). Lehulz, C.: 333 (26). Leitão-Filho, H.F.: 9570 (23). Lemos, M.H.O.: 14 (23). Lems, K.: s.n. NY s.n. (23). Leoni, L.S.: 2044 (10). Lima, H.C.: 387 (20); 1284 (23). Lima, J.S.: 275 (10); 351 (10); 13255 (10). Lima, L.R.: 36 (20); 37 (20); 38 (20); 62 (20); 132 (20); 143 (20); 287 (10); 294 (16); 295 (16); 296 (16); 314 (23); 315 (23); $316(23) ; 319(17.1)$; 320 (6); 321 (9); 325 (17.1); 326 (17.1); 327 (17.2); 337 (26); 352 (3); 353 (14); 355 (7); 357 (23). Lindeman, J.C.: 2421 (17.2); 2534 (17.2); 5019 (26); 5536 (23). Lindeman, J.C.: s.n. ICN 8124 (16); ICN 20802 (9); PACA 76210 (16). Lisboa, M.A.: s.n. OUPR 6103 (23). Lombardi, J.A.: 503 (20); 504 (20); 3226 (20). Longhi-Wagner, H.: 3001 (6). Lorentz, P.: s.n F 3919 (26); MO 2020529 (26); MO 2020530 (26); W 3382 (26); W 3384 (26). Lorentz, P.G.: 65 (1); 1151 (26). Lossen, W.: MO s.n. (1). Lourteig, A.: 2771 (26); 2835 (26). Luederwaldt, H.: s.n. SP 13726 (6). Lund: s.n. P s.n. (10). Lundell, C.L.: 12334 (12); 12335 (12); 12273 (12).

Maas, P.J.M.: 3191 (6). Macedo, A.: 4133 (5). Machado, O.: s.n. K s.n. (23); RB 71131 (23). Magalhães, H.: 7036 (23). Magalhães, M.: 1060 (3); 1062 (23); 1105 (3); 1109 (3); 2727 (17.2); 2824 (10); 4997 (23); 17680 (17.2). Maguire, B.: 49293 (23); 49307 (10). Mancera O., A.: $156(8)$.

Mantone, L.: 845 (23). Mariath: 11 (16). Markgrat: 3696 (6). Marques-Leitão, M.R.S.M.: s.n. BHCB 45744 (10); BHCB 45760 (10). Martinelli, G.: 117 (10); $1078(6) ; 6159$ (23); 7763 (6). Martinez, J.L.: 1014 (8). Martins, E.: 26467 (17.2); 26486 (6). Martins, H.F.: 125 (23). Martius: 846 (23); 854 (3); 1128 (10); 1130 (23). Mattos, $J .: 5831$ (26); 12120 (17.1); 14357 (17.2); 15903 (17.2); 15413 (10); 15941 (6); 16197 (6); 16356 (6). Mattos, J.: s.n. PACA 60711 (4); PACA 64216 (16); UEC 4685 (17.2); 11978 (17.2); 15041 (17.2); PACA 61066 (17.2). Mauhs, J.: s.n. PACA 85120 (16); PACA 85121 (16). Mautone, L.: 114 (23). Medrano, F.G.: 9612 (12). Meijer, A.: 32 (17.1). Meijer, A.: s.n. MBM 208210 (17.1). Meireles, L.D.: 293 (6); 339 (6). Mello-Silva, R.: 1379 (10); 2621 (23). Mendoza, C.A.G.: 900 (12). Merxmüller, H.: 255776 (6). Mexia, Y.: 4012 (23); 4288 (23). Miotto, S.: 999 (16). Miranda, F.: 4450 (8). Montes, A.J.E.: 27758 (26). Moore Jr., H.E.: 3768 (12). Moreira Filho, H.: 187 (17.2). 
Morong, T.: 518 (26). Mosén: 2000 (10). Mota, R.C.: 83 (23); 2144 (20). Muniz, A.S.: 58 (26).

Nicolack, V.: 12 (23). Nicolau, S.A.: 234 (6). Nóbrega, M.A.: 60 (13); 70 (13); 250 (13). Nunes, P.R.M.: 225 (23). Occhioni, P.: 8235 (23); 8682 (6).

Oliveira, A.M.: 19 (10). Oliveira, J.A.: 146 (23). Oliveira, J.E.: 578 (23). Oliveira, P.I.: 128 (17.1); 152 (17.2); 648 (17.2). Ortega, L.C.S.: 2341 (18). Ortiz, M.: 1203 (18).

Pabst, G.F.J.: 4200 (6); 5681 (23). Paciornik, E.F.: 298 (17.2). Parra, L.R.: 10 (6). Paula, J.: 2144 (10). Pedersen, T.M.: 4775 (26); 7603 (18); 9243 (26); 9286 (18); 14764 (5); 15893 (26); 16304 (1). Pennell, F.W.: 17736 (12). Pennington: s.n. CTES 38140 (26). Pereira, E.: 2129 (23); 2548 (23); 2668 (10); 5455 (23); 6440 (16); 7574 (6); 7653 (23); 8291 (17.2). Pereira-Noronha, M.R.: 561 (5). Pérez, E.: 3945 (8). Pérez, L.: 373 (18). Pfadenhauer: 290 (9). Pimentel, M.: 64 (10). Pinto, G.C.P.: $415 / 83$ (13). Pirani, J.R.: 367 (23); 1931 (2); 2877 (23); CFSC 7686 (20). Plowman, T.: 2835 (6). Pohl: 1634 (3); 3468 (10). Poloni, M.T.: 4416 (16). Portes, M.C.: s.n. MBM 171159 (15). Porto, M.L.: 1558 (16); 1611 (16); 2383 (16). Porto, P.C.: 2091 (6); 2687 (6); 2715 (6); 2739 (6); 2973 (6). Porto, P.C.: s.n. MG 49542 (6); RB 20759 (6). Punt, W.: 1969 (23). Purpus, C.A.: 1451 (12); 3451 (12); 5062 (12).

Queiroz, L.P.: 3836 (13). Quintero, L.G.: 2791 (12).

Rambo B.: s.n HUCS 5655 (17.2); PACA 1815 (16); PACA 2540 (16); PACA 4293 (26); PACA 4316 (16); PACA 4330 (16); PACA 4567 (16); PACA 4624 (16); PACA 4831 (16); PACA 4990 (16); PACA 8496 (16); PACA 8624 (16); PACA 8810 (16); PACA 31088 (16); PACA 31784 (17.2); PACA 32203 (16); PACA 32425 (16); PACA 34765 (16); PACA 35238 (16); PACA 36210 (26); PACA 43128 (16); PACA 44903 (16); PACA 45186 (9); PACA 45352 (16); PACA 45539 (16); PACA 45656 (16); PACA 45985 (17.2); PACA 46285 (16); PACA 46768 (9); PACA 47176 (16); PACA 48773 (9); PACA 48799 (9); PACA 48970 (17.2); PACA 49354 (16); PACA 49407 (16); PACA 49522 (17.2); PACA 50064 (16); PACA 50066 (16); PACA 50076 (16); PACA 50106 (16); PACA 50160 (16); PACA 50161 (16); PACA 50164 (16); PACA 51550 (17.2); PACA 51763 (17.2); PACA 52027 (26); PACA 52787 (16); PACA 52967 (16); PACA 52969 (16); PACA 53795 (16); PACA 53855 (16); PACA 53879 (16); PACA 53911 (16); PACA 53968 (16); PACA 53975 (16); PACA 54764 (9); PACA 54824 (9); PACA 55050 (16); PACA 55051 (16); PACA 55886 (9); PACA 55887 (9); PACA 56267 (16); PACA 56757 (16); PACA 61458 (9); PACA 61459 (9). Rambo, B: 110 (9). Rapini, A.: 755 (20). Rauscher, I.: 3 (23); 43 (17.2). Regnell, A.F.: 1082 (10); 1083 (5). Regnell, A.F.: s.n. G s.n. (10). Reitz, R.: 1995 (17.2); 3637 (26); 3706 (23); 4801 (23); 4906 (17.2); 9758 (23); 10791 (17.2); 11654 (17.2); 11667 (14); 12326 (17.2); 12329 (17.2); 12754 (17.2); 13630 (17.2); 13634 (14); 13737 (17.1); 13775 (7); 13779 (7); 16307 (26); 17657 (16); 17794 (17.2); 17850 (17.2). Renvoize, S.A.: 2896 (26). Ribas, O.S.: 379 (23); 926 (15); 943 (15); 990 (23); 1211 (14); 1449 (23); 1451 (15); 1889 (23); 3524 (23); 3655 (7); 3673 (23). Riedel: 374 (10). Riedel: s.n. NY 00503996 (10); NY 00503997 (10); NY 00504026 (3); NY s.n. (5); NY s.n. (10); NY s.n. (23); P s.n. (10); P s.n. (23); W s.n. (23). Riina, R.: 1315 (20); 1372 (23). Rizzini: 1149 (10). Robim, M.J.: 564 (17.2); 699 (6); 794 (6); 8433 (17.2). Robim, M.J.: s.n. SP 237470 (17.2). Rocha L.: s.n. MBM 226622 (17.2). Roderjan, C.V.: 774 (23); 925 b (15); 950 (23); 1503 (23). Rodrigues, R.S.: 65 (26); 398 (17.2); 400 (17.2); 401 (17.2); 407 (17.2); 410 (17.2); 452 (17.2); 454 (23); 455 (23); 456 (23); 468 (17.2); 479 (16); 484 (26); 488 (16); 489 (16); 491 (26); 930 (16); 932 (16). Rojas, T.: 4825 (18); 6092 (18). Romaniuc Neto, S.: 890 (23). Rombouts, J.E.: s.n. IAC 2594 (17.2), SP 40755 (17.2). Roque, N.: 4493 (13). Roseugurt, B: 2332 (26). Roshel, M.B.: 229 (10); 547 (10). Rossi, L.: 1452 (6); 1547 (6). Rossoni, M.G.: 96 (21); 225 (21).
Roth, L.: s.n. ICN 68262 (16). Rubio, H.: 2042 (8). Rzedowski, J.: 9479 (12); 36942 (8); 48692 (12).

Sem Coletor: G 5335 (10); OUPR 6102 (24); OUPR 6115 (3); RB 10303 (10).

Salinas T., A.: 5802 (12). Salzmann: s.n. B s.n. (12). Sampaio, A.: 7076 (10). Santos, E.P.: 157 (23); 329 (23). Scaramuzza, C.A.: 172 (23); 877 (23). Schawcke: s.n. OUPR 6124 (20). Schinini, A.: 1362 (18); 4426 (18); 4893 (26); 5410 (26); 5846 (26); 7194 (26); 16796 (26); 17041 (19); 17150 (19); 17559 (26); 18390 (26); 18770 (26); 21260 (18); 23497 (26). Schott: 1621 (23); 4200 (23). Schuech: s.n. W s.n. (23). Schwabe, W.: s.n. B 100086890 (6); B 100086892 (6). Schwacke: 2778 (10); 5480 (3); 13703 (10). Schwacke: s.n. ВHCB 582 (3); BHCB 3420 (3); P s.n. (23). Schwartz, J.G.: 1297 (26); 3401 (26); 4738 (26); 10548 (26). Schwarz, G.J.: 11365 (18). Scur, L.: 456 (16); 691 (16); 739 (16). Sehnem, A.: 5139 (16); 8454 (16). Sehnem, A.: s.n. PACA 4240 (16); PACA 4297 (16). Sellow: 216 (23); 817 (23); 1147 (3); 2074 (10); 2112 (23); 2113 (10); 3488 (26). Sellow: s.n. G 5335 (26); P s.n. (26). Shepherd, G.J.: $97-79$ (6); 5776 (30). Silva, A.G.: s.n. OUPR (3). Silva, F.A.: 595 (16). Silva, F.C.: 1787 (23). Silva, J.L.: s.n. OUPR 2343 (10). Silva, J.M.: 833 (23); 2320 (23). Silva, J.S.: 183 (5). Silva, M.M.: 136 (13); 155 (13). Silva, S.M.: s.n. NY 00504104 (26); UPCB 20579 (26). Silveira, N.: 11860 (23). Silvestre, M.S.F.: 83 (6). Siqueira, J.: 1858 (10). Smith, L.B.: 6617 (23); 7360 (23); 7870 (16); 8123 (17.2); 8488 (23); 8513 (23); 8959 (17.2); 10153 (23); 10574 (23); 10854 (7); 10949 (17.2); 11470 (16); 12153 (17.2); 13563 (17.1); 13606 (17.2); 14451 (17.2); 14528 (17.2). Soares, A.: 176 (15). Sobral, M.: 802 (9); 3014 (16); 3030 (16); 4928 (16); 5114 (21); 5115 (21); 5640 (3); 8116 (26). Solomon, J.C.: 10207 (19). Soria, N.: 3180 (18); 3520 (18). Sota, A.V.: 733 (1); 1463 (1). Sousa, H.O.: s.n. BHCB 16017 (23). Souza, A.: s.n. F 2170918 (23). Souza, A.B.: 4 (10). Souza, V.C.: 2073 (23); 3434 (20); 4042 (17.2); 5426 (13); 7030 (23); 10013 (23); 10062 (10); 10069 (10); 10073 (10); 10101 (10); 10106 (10); 12193 (23); 23054 (13); 23833 (5). Spichger, R.: 1600 (18). Stehmann, J.R.: 723 (17.2); 2504 (6). Stehmann, J.R.: s.n. BHCB 28399 (23), MBM 194132 (23), SPF 112245 (23). Steven: s.n. GDC s.n. (3). Stuckert, T.: 2534 (1); 3240 (1); 6423 (1); 14157 (1); 16653 (1); 19430 (1). Sucre, D.: 3061 (6); 3863 (23); 5135 (6).

Tamandaré, T.: 6364 (6). Tamashiro, J.Y.: 857 (10); 26649 (17.2). Tavares, J.S.: 323 (23). Teixeira, W.A.: s.n. BHCB 25086 (10). Tenorio L., P.: 6880 (12); 12255 (12). Tessmann, G.: s.n. MBM 263840 (17.2); MBM 265925 (17.1). Thomas, C.: 1075 (10). Thomas, W.W.: 6175 (23). Tiritan, O.: 480 (5); 537 (5). Toledo, T:: 696 (6). Torquato, M.G.V.: s.n. BHCB 17284 (3). Troncoso, N.S.: 1022 (26); 1336 (26). Tsugaru, S.: B-2361 (17.2).

Ule, E.: 1178 (23); 1560 (10).

Vasconcellos, J.: s.n. ICN 7041 (17.2). Vasconcelos, M.F.: s.n. BHCB 52574 (10). Vauthier: s.n. W s.n. (23). Velten, S.B.: 3 (10); 4 (10). Ventura, E.: 8270 (12). Verter, W.G.: 849 (26); 1604 (26). Vilchis, I.D.: 217 (8); 226 (8); 597 (8). Villafañe, M.: 390 (1).

Warming, M.: 1707 (10). Warming, M.: s.n. G 41 (10); P s.n. (10). Wasum, R.: 122 (16); 683 (16); $1418(26) ; 1553(16) ; 1588(16) ; 2049$ (16); 3204 (16); 4448 (16); 6449 (16); 8652 (16); 8656 (16); 10239 (16). Wasum, R.: s.n. HUCS 12148 (16), MBM 220245 (16), MO 5696769 (16). Wawia, H.: 388 (6).

Xavier, S.: 42 (17.2); 110 (6); 173 (17.2); 308 (17.2); 309 (17.2); $310(6)$.

Yamamoto, K.: 26726 (6); 26727 (6); 26744 (6).

Záchia, R.A.: 1424 (26); 2686 (16). Zappi, D.C.: CFCR 11154 (10). Zardini, E.: 2785 (18); 2935 (26); 3525 (24); 4042 (18); 5041 (18); 5223 (18); 6718 (18); 8668 (18); 8681 (18); 10190 (18); 10191 (18); 10200 (18); 11887 (18); 12657 (18); 15537 (18); 49614 (23). Ziller, S.R.: 370 (17.1); 1725 (23); 1842 (17.2). 


\section{Táxons excluídos de Croton seção Lamprocroton (Müll. Arg.) Pax}

1. Croton alabamensis E.A. Smith, in Chapman, Fl. South. U.S., Suppl.: 648. 1883.

Material examinado: Estados Unidos: Alabama: Bibb County: próximo das Pratelairas Ferry, 22 fev. 1953 (fl), A.M. Harvill Jr. 8998 (MBM). Centreville: acima de Schultz Creek, 14 abr. 1970 (fl), R. Kral 38500 (WIS). Tuscaloosa County: 5,5 milhas acima de Holt, 4 out. 1912 (fl), H.H. Bartlett 3326 (WIS); 10 milhas acima de Tuscaloosa, rio Warrior, 9 mar. 1935 (fl), R.M. Harper 3297 (SPF); rio Black Warrior, 1 milha ao norte de Thinly, 13 mar. 1955 (fl), B. Sargent s.n. (WIS s.n.).

Segundo Govaerts et al. (2000) há duas variedades em C. alabamensis: a variedade típica, que ocorre no estado do Alabama e, C. alabamensis var. texensis Ginzbarg, que ocorre no estado do Texas. Todos os indivíduos aqui analisados tratam-se, muito provavelmente, da segunda variedade. Em C. alabamensis as pétalas das flores pistiladas são bastante desenvolvidas caráter esse observado, por exemplo, por Ferguson (1901). Pétalas das flores pistiladas bem desenvolvidas não constituem um caráter comum na maioria das espécies de Croton e, de acordo com Webster (1993), isso não é previsto para as espécies da seção Lamprocroton. Entretanto, nesse mesmo trabalho (Webster 1993) o autor cita C. alabamensis como uma das espécies representativas da seção. Em um trabalho posterior Webster et al. (1996) tratam a espécie como pertencente à seção Argyrocroton. Além da existência de pétalas desenvolvidas nas flores pistiladas alguns outros caracteres morfológicos observados em C. alabamensis são incomuns em outras espécies de Croton. Por exemplo, em C. alabamensis as anteras formam um ângulo especial entre si, ou seja, o tipo de inserção das anteras nos filetes é diferente daquela observada na maioria das espécies do gênero; além disso, em C. alabamensis os estiletes são em número de quatro e não apresentam ramificação, ao passo que nas demais espécies do gênero eles são em número de três e, em geral, ramificados.

$\mathrm{Na}$ mais recente proposta seccional para o gênero Croton realizada por Webster (1993), não há uma seção que agrupe plantas com indumento lepidoto, estiletes não ramificados e em número de quatro e pétalas das flores pistiladas bem desenvolvidas. A seção Eluteria inclui plantas com indumento lepidoto e pétalas das flores pistiladas bem desenvolvidas, entretanto os representantes dessa seção possuem inflorescências, em geral, axilares e estiletes multífidos características não encontradas em $C$. alabamensis cujos indivíduos possuem inflorescências terminais e estiletes não ramificados.

Em um trabalho preliminar sobre filogenia de Croton utilizando-se os marcadores moleculares ITS e $\operatorname{trnL}$-trnF, realizado por Berry et al. (2005a), C. alabamensis emerge juntamente com o gênero Moacroton, como grupo-irmão do clado onde está a maior parte das espécies de Croton analisadas (exceto C. lobatus e C. praetervisus). Assim, para que o gênero Croton torne-se um grupo monofilético é necessário ou a sinonimização de Moacroton sob Croton ou a exclusão de $C$. alabamensis do gênero. Vê-se que, tanto os caracteres morfológicos encontrados em $C$. alabamensis quanto os moleculares têm demonstrado que, provavelmente, C. alabamensis não deve ser tratado como um representante da seção Lamprocroton e talvez seja tampouco um representante do gênero Croton estando mais próximo dos representantes de outros gêneros da tribo Crotoneae como, por exemplo, Moacroton. Assim, propõe-se aqui a exclusão de $C$. alabamensis de $C$. sect. Lamprocroton.

No protólogo, o autor não cita uma coleção para C. alabamensis, deste modo será necessário neotipificar esse nome.

2. Croton isabelli Baill., Adansonia 4: 318. 1864. Tipo: [Brasil], 'Prov. de Rio-Grande-do-Sul', 1835, Isabelle [1895] (lectótipo, P! aqui designado; isolectótipos, F!, K!). Remanescente do síntipo original: [Brasil], 'Prov. de Rio-Gande-do-Sul', [1816-1821], Saint-Hilaire C2-2774 (P!).

Croton julopsidium Baill., Adansonia 4: 318. 1864. syn. nov. Tipo: [Brasil], 'Prov. de Rio-Grande-do-Sul', [1833], Gaudichaud 1675 (holótipo, $\mathrm{P} !)$.

Material examinado: Argentina: Corrientes: Santo Tome: Cerovy Grande, sem data (fr), C. Ibarrola 1603 (NY). Brasil: Santa Catarina: Florianópolis: rio Tavares, próximo ao estádio de futebol, 15 jul. 1987 (fl), M.L. Souza, L. Amaral \& M. Fronza 1104 (FLOR n.v., MBM); id., 15 jul. 1987 (fl), M.L. Souza, L. Amaral \& M. Fronza 1105 (FLOR n.v., MBM). Rio Grande do Sul: Cachoeira do Sul: abr. 1983 (fl), M. Sobral \& D. Falkenberg 1723 (RB). Canela: Toca para Canela, 10 fev. 1941 (fl), B. Rambo s.n. (PACA 4735); Passo do Inferno para Canela, ago. 1949 (fl), A. Spies s.n. (PACA 47400). Gravataí: 12 fev. 1950 (fl), B. Rambo s.n. (PACA 50569); 1 dez. 1950 (fl, fr), B. Rambo 49279 (ICN). Montenegro: Pareci para Montenegro, 30 maio 1945 (fl), E. Henz s.n. (PACA 29735); Linha Pinhal para Montenegro, 26 out. 1949 (fl, fr), A. Sehnem 3950 (PACA); Pinhal para Montenegro, 20 nov. 1950 (fl, fr), A. Sehnem 5056 (PACA). Santa Cristina do Pinhal: 9 set. 2002 (fl, fr), S. Bordignon s.n (ICN 129246). São Leopoldo: 15 abr. 1934 (fl), B. Rambo s.n. (PACA 1457); Monte das Cabras para São Leopoldo, 7 dez. 1948 (fl), B. Rambo s.n. (PACA 38593); Steinkopf para São Leopoldo, 20 dez. 1948 (fl), B. Rambo s.n. (PACA 39004). São Luiz: Cerro Largo para São Luiz, 1946 (fl), Irmão Augusto s.n. (PACA 37007). São Vicente do Sul: cerro Loreto, set. 1986 (fl, fr), M. Sobral et al. 5129 (ICN n.v., UEC). Torres: Torres-Faxinal, próximo a Campo Bonito, 28 jun. 1980 (fl), L.R.M. Baptista \& J.L. Waechter s.n (ICN 47661).

Tanto $C$. isabelli quanto $C$. julopsidium foram descritas por Baillon (1864) e distinguidas, principalmente, por meio do número de estames das flores, 20 na primeira e 15 na segunda. $\mathrm{O}$ mesmo autor classificou ambas as espécies na seção Velamea, juntamente com $C$. campestris, $C$. grandivelum entre outras. Nessa seção encontravam-se os táxons com indumento estrelado-tomentoso, androceu formado por 15 a 20 estames e estiletes uma vez bífidos. Em 1866, Mueller tratou esses dois táxons ( $C$. isabelli e $C$. julopsidium) como pertencentes à seção Decarinium e, juntos, eles formavam um grupo informal separado das demais espécies da seção por conta das escamas longamente estipitadas e radiadas. Na Flora brasiliensis, Mueller (1873) manteve sua posição anterior, porém aí incluiu C. isabelli e C. julopsidium na série Lamprocroton da seção Decarinium que congregava as plantas lepidotas, ou seja, o autor considerou como do tipo lepidoto o indumento dessas duas espécies ao contrário de Baillon (1864). A análise dos tipos e de diversos materiais mostrou que, na prática, é inviável distinguir $C$. isabelli e $C$. julopsidium já que ambas ocorrem na região Sul do Brasil, possuem indumento da folhagem densamente tomentoso, constituído por tricomas apressoestrelados com coloração dourada a ferrugínea e androceu formado por 15 estames, isto é, com os raios laterais pouco unidos entre si. Deste modo propõe-se aqui a sinonimização desses dois nomes. Além disso, segundo a recircunscrição proposta por Webster (1993), os representantes da seção Lamprocroton possuem indumento da folhagem, pelo menos em parte, lepidoto. Os tricomas observados em $C$. isabelli são, como já comentado, do tipo apresso-estrelado, isto é, os raios laterais são, em geral, unidos em cerca de $10 \%$ do seu comprimento total o que nos leva a propor a exclusão desse táxon da supracitada seção.

3. Croton myricifolius Griseb., Nachr. Konigl. Ges. Wiss. Georg-Augusts-Univ. 1: 173. 1865. Tipo: 'Cuba orientali', [1860-1864], Wright 1969 (holótipo, G!; isótipo, K; foto do holótipo, NY! ex G).

Nome popular: "romerillho de costa" (E.L. Ekman 8702)

Material examinado: Cuba: Estacion Naval de Caimanera, 6 fev. 1919 (bt), B. Hioram \& C.J. Ramsden 2325 (NY). Baracoa: Romero: 
Serra de Imías, 17 jul.-4 ago. 1924 (fl), F. Leon 12267 (NY). Ciego de Avila: Cayo Coco: Punta Colorada, elev. 3-4 m, 19 set. 1988 (st), A.P. Asso 1098 (NY). Guantánamo: Imias: San Antonio, zona próxima a mina de gesso de Baitiquiri, elev. 4000-6000 m, 13 maio 1980 (fl), J. Bisse et al. s.n (HAJB 43195). Maisí: Baracoa, Oriente, 6 fev. 1952 (st), Acuña \& D. Barreto 17412 (NY); entre Cueva del Agua e El Canto, Punta Maisí, 24 abr. 1986 (fl.), E. Genes et al. s.n. (HAJB 59213). Habana: Jardim Botânico, ca. $15 \mathrm{~km}$ ao sul da cidade, 1 jul. 1990 (fl), R.M. Harley 27913 (K). Benito Alain: Cape Cruz, jul. 1935 (st), B. León 16333 (NY); El Dudoso Cliffs, 30 dez. 1938 (bt), B. León \& M. Vitorin 18622 (NY). Oriente: 10-25 mar. 1912 (bt), N.L. Britton, E.G. Britton \& J.F. Cowell 12636 (NY). Guantánamo: 25 set. 1914 (st), E.L. Ekman 2922 (NY). Santiago: colinas entre Campo Columbia e o mar, 16 dez. 1916 (st), E.L. Ekman 8518 (K, NY); id., Aguadores, 4 nov. 1917 (fl), E.L. Ekman 8702 (K, NY). Santa Clara: Cacilda: 16 mar. 1910 (st), N.L. Britton \& P. Wilson 5592 (NY); 28 mar. 1924 (fl), E.L. Ekman 18870 (K). Punta Colorada: Cienfuegos Bay, 18 mar. 1910 (fl), N.L. Britton \& P. Wilson 5630 (NY). Igrata Oriental: Bartolina, 19 ago. 1930 (st), B. León 14628 (NY). Santiago de Cuba: Renté, Bahia de Santiago, 30 jul. 1918 (bt), B. Horam 2029 (NY); 1919 (fl), I.C. March 157 (NY); Daiquiri-Berraco, mar. 1983 (fl), R. Oviedo et al. s.n. (WIS s.n.). Silla de Cayo: Cayo Romano: Camaguey, 9-11 out. 1909 (bt), J.A. Shafer 2520 (K, NY); 22 fev. 1916 (st), Y.T. Roig \& Ballon 1345 (NY).

Croton myricifolius é uma espécie endêmica de Cuba, onde é comum no Oriente (Borhidi 1977) e, de acordo com Carabia (1942), nessa região, é um táxon bastante conhecido e pouco variável, com folhas medindo de 0,5 a $1,5 \mathrm{~cm}$ de comprimento ao passo que indivíduos que ocorrem nas demais áreas do país possuem folhas maiores, variando de 2,0 a 3,0 cm de comprimento. Webster (1993) incluiu C. myricifolius na seção Lamprocroton, muito provavelmente, por conta das folhas relativamente pequenas e estreitas com a face abaxial coberta por tricomas tipicamente lepidotos. Todavia, a presença de inflorescências axilares, bastante congestas, glomeruliformes e de flores pistiladas com estiletes multífidos não são características da seção Lamprocroton deste modo, propõe-se aqui a exclusão de C. myricifolius da seção Lamprocroton.

4. Croton rosmarinoides Millsp., Bahama Fl. 222. 1920. Tipo: 'Cuba orientali', Wright 1968 (holotipo, G; isótipo, K).

Croton rosmarinifolius Griseb., Nachr. Konigl. Ges. Wiss. Georg-AugustsUniv. 1: 174. 1865. nom. ileg.

Material examinado: Bahamas: Atwood Cay: 3-4 dez. 1907 (fl), P. Wilson 7385 (K). Cat Island: região central da ilha, 18 ago. 1967 (fl), R. Byrne 254 (A n.v., WIS). Great Exuma: 22-28 fev. 1905 (fl), N.L. Britton \& C.F. Millspaugh 2978 (K). Cuba: Oriente: Ensenada de Mora: 26-29 mar. 1912 (fl), N.L. Britton, J.F. Cowell \& J.A. Shafer 1306 (K, NY n.v.). Guantánamo: 24 set. 1914 (fl), E.L. Ekman 2888 (K). Santiago: oeste da Playa Sibaney, 8 nov. 1917 (fl), E.L. Ekman 8728 (K). Santiago de Cuba: Caminho de Berraco, mar. 1983 (fl), R. Oviedo et al. s.n. (WIS 147).

Segundo Carabia (1942) trata-se de uma espécie bastante semelhante a $C$. myricifolius Griseb., da qual pode ser diferenciada pelas folhas com as duas faces lepidotas, enquanto naquela apenas a face abaxial é indumentada. Croton rosmarinoides ocorre nas Bahamas e em Cuba, sendo os indivíduos provenientes das duas localidades, bastante semelhantes entre si, porém as plantas de Cuba possuem, em geral, folhas maiores e mais largas (Carabia 1942). Apesar de não terem sido examinados materiais com flores estaminadas, Britton \& Millspaugh (1920) comentam que o androceu é constituído por apenas 6 estames. Segundo o protólogo, os estiletes de C. rosmarinoides são 4-fidos e segundo Carabia (1942) eles são apenas 2-fidos, entretanto as flores pistiladas aqui examinadas apresentam estiletes 3 -fidos a partir da metade distal. Webster (1993) cita C. rosmarinoides como uma das espécies representativas da seção Lamprocroton, contudo alguns dos caracteres morfológicos, tais como número de estames e tipo de ramificação dos estiletes, não são congruentes com aqueles propostos na circunscrição dessa seção assim, é proposta aqui a exclusão desse táxon da supracitada seção.

Carabia (1942) utiliza o nome C. rosmarinifolius no seu trabalho sobre o gênero Croton em Cuba, entretanto este binômio é ilegítimo por se tratar de um homônimo posterior. De acordo com Govaerts et al. (2000) há pelo menos quatro homônimos de C. rosmarinifolius. Deste modo, Millspaugh, em 1920, faz a correção nomenclatural citando um novo nome para $C$. rosmarinifolius-C. rosmarinoides e colocando o nome C. rosmarinifolius sob sinonímia (Britton \& Millspaugh 1920). Govaerts et al. (2000) citam o binômio C. rosmarinifolius Griseb. como ilegítimo e utilizam o nome C. rosmarinoides como correto.

\section{Táxons pouco conhecidos e de posição duvidosa}

1. Croton catamarcensis Ahumada, Darwiniana 37 (1-2): 167. 1999. Tipo: 'Argentina, Catamarca, Depto. El Alto', 16 fev. 1972 (fl.), Menéndez Sevillano et al. 9376 C (holótipo, LIL).

Ahumada (1999) propõe a inclusão de C. catamarcensis na seção Lamprocroton, cujos representantes são arbustos monóicos ou dióicos, com indumento lepidoto. Entretanto, os tricomas encontrados em praticamente todos os órgãos de $C$. catamarcensis possuem os raios laterais completamente livres ou unidos em menos de $20 \%$ do seu comprimento total não sendo assim considerados como do tipo lepidoto, mas sim estrelado ou apresso-estrelado, respectivamente. Infelizmente não foram observadas coleções desse táxon já que o holótipo não se encontra depositado no herbário citado no protólogo, mas sim no herbário CTESN (Ahumada, com. pess.), não visitado. As outras coleções citadas no protólogo, os parátipos, também se encontram, provisoriamente, no CTESN. A prancha de $C$. catamarcensis apresentada no protólogo é bastante completa com hábito, detalhes do indumento e flores estaminada e pistilada. Assim, baseado na prancha e na descrição, muito provavelmente, $C$. catamarcensis não deve ser um representante de $C$. sect. Lamprocroton por conta, principalmente, do indumento presente nessa espécie que não é do tipo previsto para os representantes da seção. Porém, preferiu-se aqui considerar este táxon como duvidoso e análises filogenéticas futuras poderão esclarecer se essa espécie deve ou não ser considerada como um representante da supracitada seção.

2. Croton constrictus Baill., Adansonia 4: 360. 1864. Tipo: [Brasil], 'Prov. de Goyaz', 1841, Gardner 3428 (holótipo, P?, não localizado).

Não foi localizada nenhuma coleção de C. constrictus. De acordo com o protólogo, o holótipo estava, originalmente, depositado no herbário de 'Delessert', posteriormente incorporado ao herbário P. Baillon (1864) incluiu esse táxon na seção Cascarilla, entretanto Mueller (1873) a classificou na série Argyrocroton da subseção Cleodora (seção Eucroton) no grupo de espécies sem glândulas na base da lâmina foliar e com estiletes uma vez bífidos. Baillon (1864) descreveu $C$. constrictus baseado em um material proveniente de Goiás, caracterizando-a por apresentar folhas longamente lanceoladas, flores estaminadas com 10 estames e flores pistiladas com sépalas também lanceoladas. Na Flora brasiliensis Mueller (1873) aceita a existência desse táxon, porém baseado em um material também proveniente de Goiás, descreve outra espécie, C. burchellii, cuja descrição é extremamente semelhante à de $C$. constrictus. Deste modo, visto as informações disponíveis até o momento, C. burchellii e C. constrictus tratam-se, provavelmente, de sinônimos, entretanto até que seja possível a análise do tipo, C. constrictus está sendo considerada uma espécie de identidade duvidosa. 
3. Croton laureltyanus Ahumada, Darwiniana 37 (1-2): 174. 1999. Tipo: 'Argentina, Corrientes, Depto. Concepción, Laguna Laurelty', 15 mar. 1986 (fl. pist.), Ahumada \& Eskuche 7327 (holótipo, CTESN n.v.; isótipo, SI n.v.). Parátipo: 'Argentina, Corrientes, Mburucuyá, Estancia Santa Teresa', 31 jul. 1949 (fl), Pedersen 389 (NY!)

Croton multirameus Ahumada, Darwiniana 37 (1-2): 176. 1999. syn. nov. Tipo: 'Argentina, Corrientes, Depto. Bella Vista, Bella Vista, barranca del Rio Paraná', 12 out. 1982 (fl. pist.), Ahumada \& Eskuche 6365 (holótipo, CTESN n.v.; isótipo, SI n.v.). Parátipo: 'Argentina, Corrientes, Depto. Lavalle, barrancas del río Paraná, 25 maio 1973 (fl.), Schinini 6601 (CTES!).

Material examinado: Argentina: Corrientes: Bella Vista: $10 \mathrm{~km}$ ao sul de Bella Vista, arroio Toropí, 13 set. 1972 (fl), A. Schinini 5226 (MO); barrancas do rio Paraná, próximo ao Balneário Municipal, $28^{\circ} 30^{\prime} 38^{\prime}$ S e $59^{\circ}$ 3' 2" W, elev. 55 m, 18 fev. 2004 (fl, fr), L.R. Lima, M.A. Farinaccio \& A.B. Junqueira 343 (SP, SPF, WIS). Concepción: $6 \mathrm{~km}$ a leste de Santa Rosa, estância Millán, 27 mar. 1975 (fl), M.M. Arbo et al. 934 (CTES n.v., RB); $11 \mathrm{~km}$ a noroete de Santa Rosa, 22 abr. 1982 (fl), S.C. Tressens et al. 2046 (CTES, ICN). General Paz: Itá Ibaté, 20 jul. 1944 (fl), G.J. Sehrraz 411 (LIL n.v., NY); 12 km a leste de Itá Ibaté, costa do rio Paraná, 9 abr. 1972 (fl), L. Mrogisnki, A. Schinini \& H. Pueyo 633 (MO); $15 \mathrm{~km}$ a leste de Itá Ibaté, margem do rio Paraná, 9 abr. 1972 (fl), L. Mroginski, A. Schinini \& H. Pueyo 746 (RB). Ituizangó: 29 dez. 1944 (fl), G.J. Schwarz 442 (LIL n.v., NY); rota 12, $2 \mathrm{~km}$ antes do desvio a Ituizangó, 25 set. 1972 (fl), A. Schinini 5421 (NY). Lavalle: barrancas do rio Paraná, 25 maio 1973 (fl), A. Schinini 6601 (CTES). Loreto: 7 maio 1945 (fl), R. Huidoro 2193 (LIL, MO). Mburucuyá: 28 nov. 1944 (fl), G.J. Schwarz 228 (LIL n.v., NY); Estância Santa Teresa, a 12 km de Mburucuyá, 2 dez. 1983 (fl), P. Cowan \& T.M. Pedersen 4089 (NY). San Miguel: $2 \mathrm{~km}$ ao sul da rota 12, km 1100, 6 out. 1971 (fl), R. Carnevali 2614 (MO). San Roque: Mantilla, fev. 1949 (fl), R.M. Crovetto 5499 (MBM); rota 118, estrada para San Miguel, próximo ao Passo Naranjito, 28 20' $17^{\circ}$ " S e 58 26'34" W, elev. 76 m, 19 fev. 2004 (fl), L.R. Lima, M.A. Farinaccio \& A.B. Junqueira 347 (MBM, SP, SPF, WIS).

Ahumada (1999) comenta que C. laureltyanus e C. multirameus Ahumada seriam táxons morfologicamente muito semelhantes, por serem ambos plantas dióicas, com folhas pequenas e sem glândulas, com face adaxial e abaxial cobertas por tricomas estrelados, sépalas das flores pistiladas desiguais e estiletes duas vezes bífidos. Segundo a autora, a distinção entre esses táxons poderia ser feita, principalmente, pelo número de estames, (13-)15-16 em C. laureltyanus e 11-14(-16) em C. multirameus, forma e dimensão das sépalas das flores pistiladas e tipo de tricoma do ovário. Entretanto, a análise de algumas coleções e de parátipos dos dois nomes deixou evidente que as características utilizadas por Ahumada (1999) são variáveis e não consistentes para sustentá-las como duas entidades assim, propõe-se aqui a sinonimização de C. multirameus sob C. laureltyanus. Apesar de Ahumada (1999) propor a inclusão de C. laureltyanus na seção Lamprocroton a presença de indumento formado por tricomas estrelados nas duas faces foliares deixa dúvidas sobre a inclusão ou não deste táxon na referida seção, assim preferiu-se não tratar este táxon na revisão taxonômica de $C$. sect. Lamprocroton, uma vez que, sua inclusão iria contra a circunscrição ora adotada para o grupo, cujos representantes possuem indumento lepidoto em pelo menos parte da folhagem. Outros trabalhos envolvendo análises filogenéticas, com mais espécies de Croton, poderão elucidar melhor as relações de parentesco de $C$. laureltyanus e as demais espécies do gênero.

4. Croton microstachys Baill., Adansonia 4: 366. 1864. Tipo: [Brasil], 'Prov. de Rio-Janeiro', [1816-1821], Saint-Hilaire 179 (holótipo, P!; fragmento do holótipo, F!; isótipo: P!).
Assim como C. constrictus Baill. C. microstachys foi descrita por Baillon (1864) e incluída por esse autor na seção Cascarilla. Entretanto, Mueller (1873) transferiu essa espécie para a série Argyrocroton, no grupo de espécies sem glândulas na base das folhas e com ovário coberto por tricomas não lepidotos. Segundo Mueller (1873) C. microstachys pode ser distinguida de $C$. constrictus por meio, principalmente, da textura e base da lâmina foliar. Trata-se de uma espécie bastante semelhante a $C$. microcarpus, táxon descrito por Mueller (1873) e também classificado por esse autor como um representante da série Argyrocroton. A análise das coleções-tipo desses dois nomes demonstrou que, muito provavelmente, se tratam de sinônimos, já que ambas possuem o hábito muito semelhante, folhas estreitas, variando de lineares a lanceoladas, com as duas faces cobertas por tricomas estrelados e sépalas das flores pistiladas também bastante estreitas deixando o gineceu completamente exposto. Nos herbários visitados, a grande maioria das exsicatas está identificada como $C$. microcarpus. O nome $C$. microstachys foi encontrado apenas na coleção-tipo. O primeiro táxon não foi incluído no tratamento taxonômico de $C$. sect. Lamprocroton, principalmente, por conta do tipo de tricoma que constitui o indumento foliar. Como comentado acima, acredita-se que $C$. microstachys seja sinônimo de C. microcarpus. Deste modo, pelo mesmo motivo C. microstachys não foi incluída na presente revisão. Vale ressaltar que, caso seja proposta a sinonimização dessas duas espécies, o nome $C$. microstachys terá prioridade sobre $C$. microcarpus, embora desse seja atualmente o binômio mais utilizado.

\section{Agradecimentos}

Os autores agradecem ao desenhista Rogério Lupo, pelas belas ilustrações; aos curadores dos herbários visitados; aos assessores, pelas valiosas contribuições; e à FAPESP, pela bolsa de doutorado concedida à primeira autora (01/10947-8).

\section{Referências Bibliográficas}

AHUMADA, L.Z. 1999. Novedades sistemáticas en el género Croton (Euphorbiaceae). Darwiniana 37(1-2): 167-184.

ALLEM, A.C. 1978. Preliminares para uma abordagem taxonômica do gênero Croton L. (Euphorbiaceae) no Rio Grande do Sul, Brasil. Bol. Mus. Bot. Munic. 34:1-33.

BAILLON, H. 1858. Étude generale du groupe des Euphorbiacees. Victor Masson, Paris.

BAILLON, H. 1864. Euphorbiacées Américaines. Adansonia 4:257-377, figs. X, XI.

BERRY, P.E., HIPP, A.L., WURDACK, K.J., VAN, EE.B. \& RIINA, R. 2005 a. Molecular phylogenetics of the giants genus Croton and tribe Crotonae (Euphorbiaceae sensu strictu) using ITS and trnL-trn-F DNA sequence data. Amer. J. Bot. 92(8):1520-1534.

BERRY, P.E., CORDEIRO, I., WIEDENHOEFT, A.C., VITTORINO-CRUZ, M.A. \& LIMA, L.R. 2005b. Brasiliocroton, a new crotonoid genus of Euphorbiaceae s.s. from eastern Brazil. Syst. Bot. 30(2):357-365.

BORHIDI, A. 1977. Revision of the genus Croton in Cuba. Ann. Hist.-Nat. Mus. Natl. Hung. 69:41-53.

BRITTON, N.L. \& MILLSPAUGH, C.F. 1920. Euphorbiaceae. In The Bahama Flora (N.L. Britton \& C.F. Millspaugh, eds.). New York, p.217-242.

BURGER, W. \& HUFT, M. 1995. Flora costaricensis: Euphorbiaceae. Fieldiana, Bot. 36: 1-169.

CARABIA, J.P. 1942. El género Croton en Cuba. Caribean Forester 3(3): 114-135.

CARRENHO, R., BONONI, V.L.R. \& BARBOSA, L.M. 1997. Glomales em áreas de recomposição de mata ciliar de Moji-Guaçu, SP, Brasil. Hoehnea 24(1):107-113. 
CORDEIRO, I. 1985. A família Euphorbiaceae na Serra do Cipó, Minas Gerais, Brasil. Dissertação de Mestrado, Universidade de São Paulo, São Paulo.

CORDEIRO, I. 1992. Flora da Serra do Cipó, Minas Gerais: Euphorbiaceae. Bol. Bot. Univ. São Paulo 13:169-217.

COYNE, J.A. \& ORR, H.A. 1989. Two rules os speciation. In Speciation and its consequences (D. Otte \& J.A. Endler, eds). Sinaeur Associates, Sunderland, p.180-207.

CROIZAT, L. 1940. Thirty-five new species of american Croton. J. Arnold. Arbor. 21:76-107.

CROIZAT, L. 1941. Preliminaries for the study of argentine and Uruguayan species of Croton. Darwiniana 5:41-462.

CROIZAT, L. 1944. Additions to the genus Croton L. in South America. Darwiniana 6(3):442-468.

ERDTMAN, G. 1952. Pollen morphology and plant taxonomy - Angiosperms. Almqvist \& Wiksell, Stockolm.

FERGUSON, A.M. 1901. Crotons of the United States. Rep. (Annual) Missouri Bot. Gard. 12:33-73.

GOMES, A.P.S. 2006. Revisão das espécies sul-americanas de Croton sect. Argyroglossum Baill. (Crotonoideae - Euphorbiaceae). Tese de Doutorado, Universidade Federal Rural de Pernambuco, Pernambuco.

GOVAERTS, R., FRODIN, D.G. \& RADCLIFFE-SMITH, A. 2000. World checklist and bibliography of Euphorbiaceae 2. Royal Botanic Gardens, Kew.

HENDERSON, A. 2005. The methods of herbarium taxonomy. Syst. Bot. 30(2):456-459.

HOLMGREN, P.K.; HOLMGREN, N.H. \& BARNETT, L.C. (eds.). 1990. Index herbariorum. 8 ed. New York Botanical Garden, New York.

JONES, K. 2003. Review of Sangre de Drago (Croton lechleri) - A south american tree sap in the treatment of diarrhea, inflammation, insect bites, viral infections, and wounds: traditional uses to clinical research. The Journal of Alternative and Complementary Medicine 9:877-896.

JOSE, T. \& INAMDAR, J.A. 1989. Structure, ontogeny, and biology of nectaries in Croton bonplandiaus Baill. Beitr. Biol. Pflanzen 64:157-165.

LÉANDRI, J. 1939. Les Croton de Madagascar et des iles voisines. Ann. Inst. Bot.-Géol. Colon. Marseille ser.5 7:1-100.

LIMA, L.R. \& PIRANI, J.R. 2003. O gênero Croton L. (Euphorbiaceae) na Cadeia do Espinhaço, Minas Gerais, Brasil. Bol. Bot. Univ. São Paulo 21(2):299-344

MAYNARD SMITH, J. 1996. Sympatric speciation. American Naturalist 100:637-650

MAYR, E. 1942. Systematic and the origin of species. Columbia University Press, New York.
MORI, S.A., SILVA, L.A.M., LISBOA, G. \& CORADIN, L. 1989. Manual de manejo do herbário fanerogâmico. 2 ed. Centro de Pesquisas do Cacau, Bahia.

MUELLER, J. 1865. Euphorbiaceae. Linnaea 34:1-224.

MUELLER, J. 1866. Euphorbiaceae exceto subordo Euphorbieae. In Prodromus systematis universalis regni vegetabilis (A.P. Candolle, ed.) v.15, pars 2, p.189-1286.

MUELLER, J. 1873. Euphorbiaceae. In Flora brasiliensis (C.F.P. Martius \& A.G. Eichler, eds.). v.11, pars 2, p.1-292, tab.1-42.

NOWICKE, J. 1994. A palynological study of Crotonoideae (Euphorbiaceae). Ann. Missouri Bot. Gard. 81(2):245-269.

PAX, F. 1890. Euphorbiaceae. In Die Naturl. Pflanzenfamilien (A. Engler \& K. Prantl, eds.). 1 ed., v.3, pars 5, p.1-119.

PAX, F. \& HOFFMANN, K. 1931. Euphorbiaceae. In Die Naturl. Pflanzenfamilien (A. Engler \& K. Prantl, eds.). 2 ed., v.19c, p.11-233.

RADFORD, A.E.; DICKSON, W.C., MASSEY, R. \& BELL, C.R. 1974. Vascular plant systematic. Harper \& Row Publishers, Inc., New York.

RIINA, R.G. 2006. Systematics of Croton sect. Cyclostigma Griseb. Tese de Doutorado. University of Wisconsin, Wisconsin.

SALATINO, A., SALATINO, M.L.F. \& NEGRI, G. 2007. Traditional uses, chemistry and pharmacology of Croton species (Euphorbiaceae). J. Braz. Chem. Soc. 18(1):11-33.

SMITH, BA. 2002. A systematic revision of Croton section Cyclostigma (Euphorbiaceae) in Ecuador. Tese de Doutorado. University of CaliforniaDavis, Califórnia.

SMITH, L.B., DOWNS, R.J. \& KLEIN, R.M. 1988. Euphorbiaceae - Croton L. Fl. Ilustr. Catarin., Fasc. EUFO, p.62-137.

STEVENS, P.F. 1998. What kind of classification should the practicing taxonomist use to be saved? In Plant diversity in Malesia 3 (J. Dransfield, M.J.E. Coode \& D.A. Simpson, eds.). Royal Botanic Gardens, Kew, p. 295-319.

WEBSTER, G.L. 1993. A provisional synopsis of the sections of the genus Croton (Euphorbiaceae). Taxon 42:793-823.

WEBSTER, G.L. 1994. Synopsis of the genera and suprageneric taxa of Euphorbiaceae. Ann. Missouri Bot. Gard. 81(1):33-144.

WEBSTER, G.L., DEL-ARCO-AGUILAR, M.J. \& SMITH, B.A. 1996. Systematic distribution of foliar trichome types in Croton (Euphorbiaceae). Bot. J. Linn. Soc. 121:41-57. 